SZEGEDI TUDOMÁNYEGYETEM

TÖRTÉNETTUDOMÁNYI DOKTORI ISKOLA

MEDIEVISZTIKA PROGRAM

\title{
Pintér-Nagy Katalin
}

A hunok és az avarok fegyverzete, harcmodora

\section{az írott források alapján}

(doktori értekezés)

Témavezetők:

Dr. Olajos Terézia egyetemi tanár

Dr. Zimonyi István egyetemi tanár 


\section{Tartalomjegyzék}

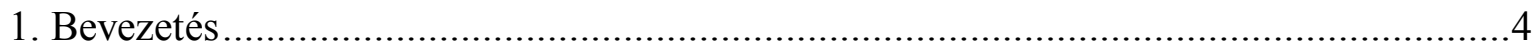

2. A korszakra vonatkozó írott források....................................................................

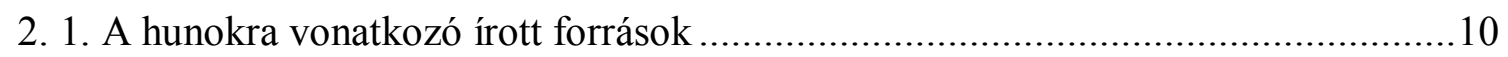

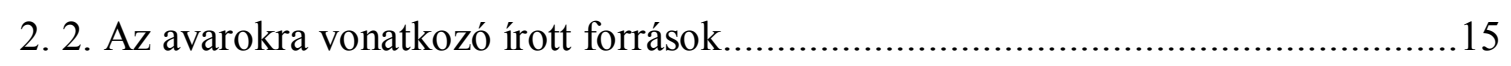

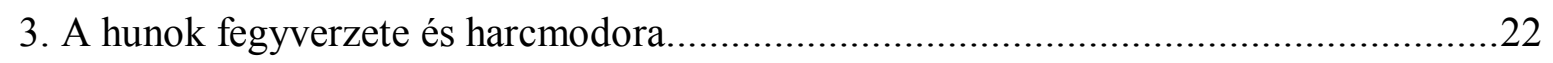

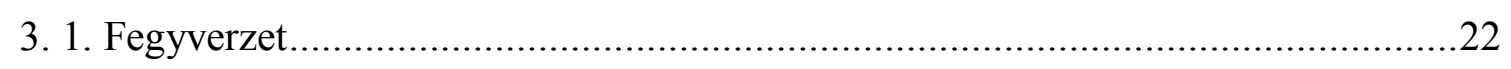

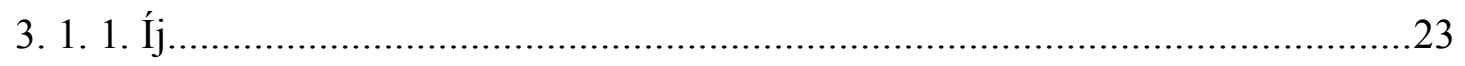

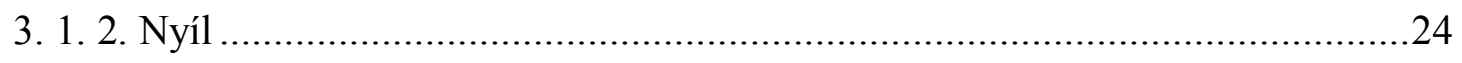

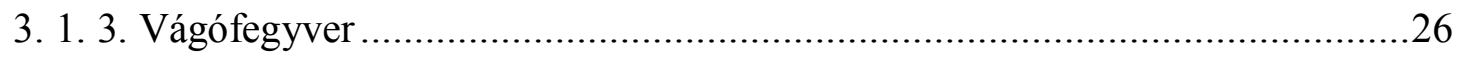

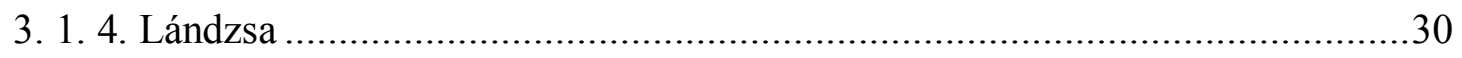

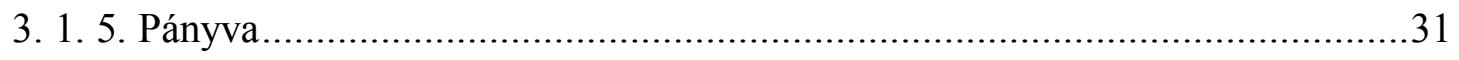

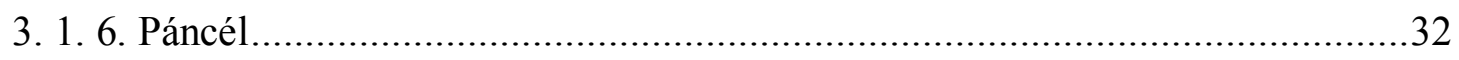

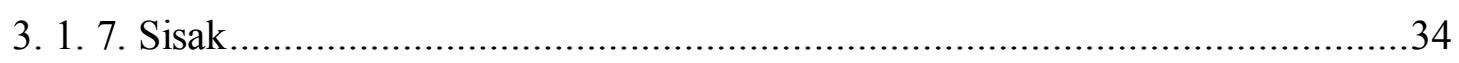

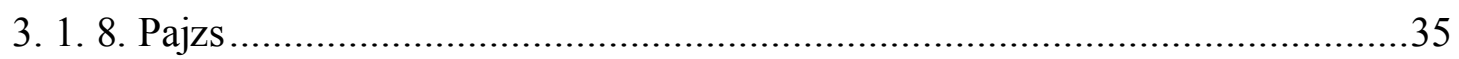

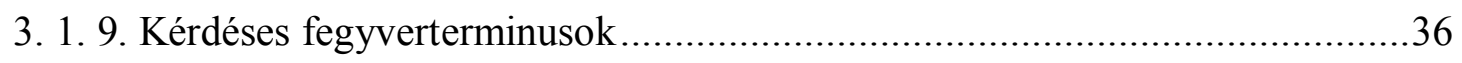

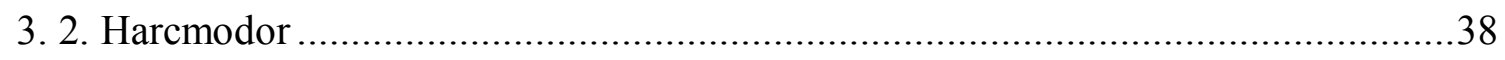

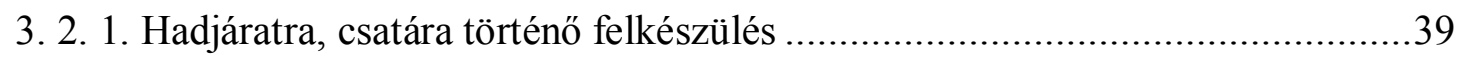

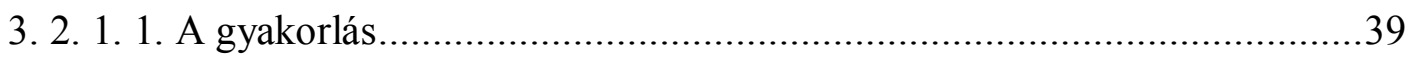

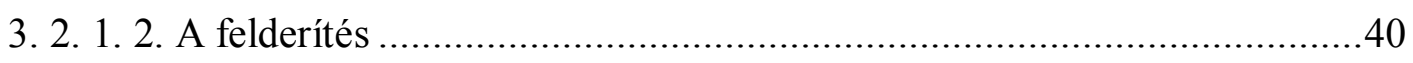

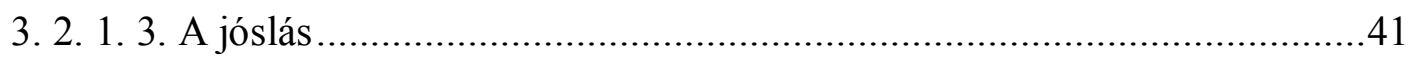

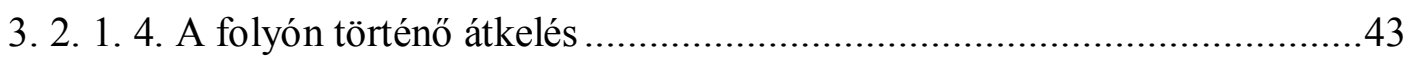

3. 2. 1. 5. Az utánpótlás kérdése .................................................................44

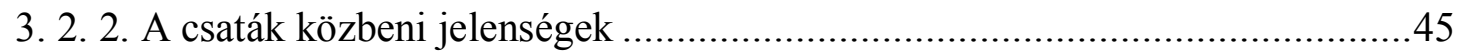

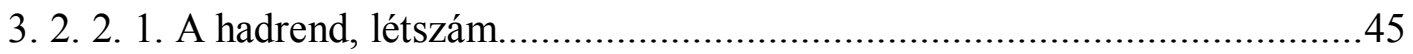

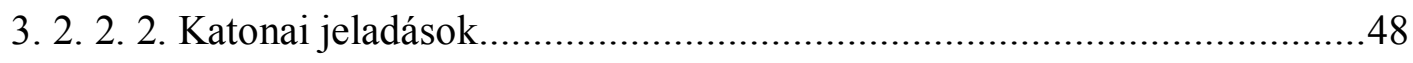

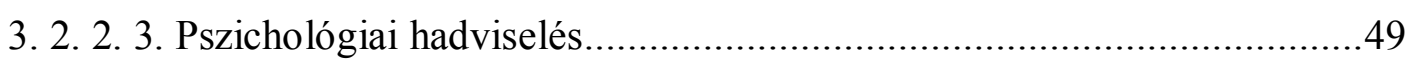

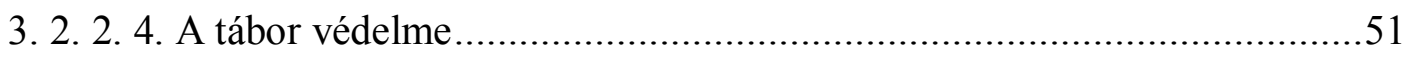

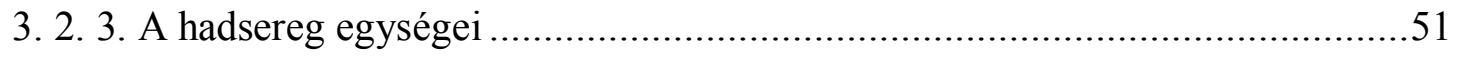

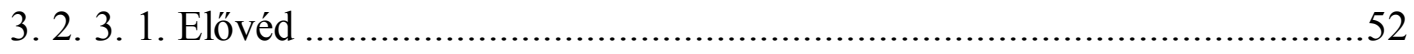

3. 2. 3. 2. Könnyüfegyverzetü lovasság.......................................................53

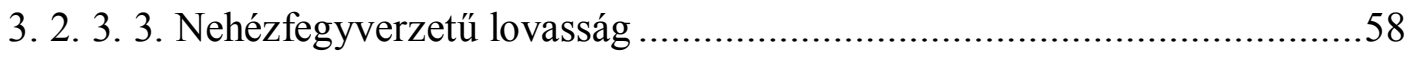

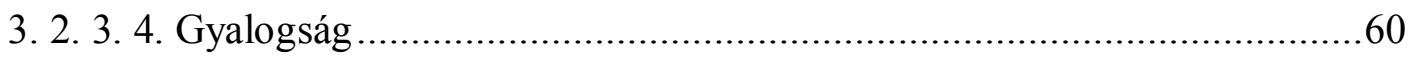




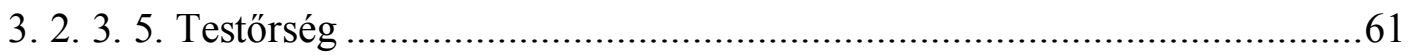

3. 2. 3. 6. „Müszaki” alakulatok (ostromtechnika) ............................................62

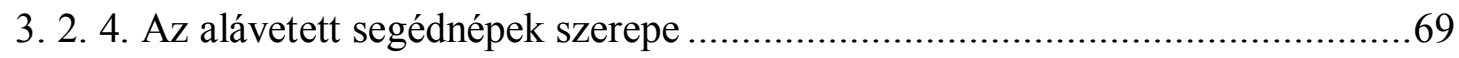

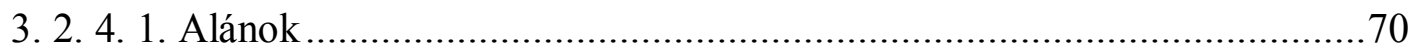

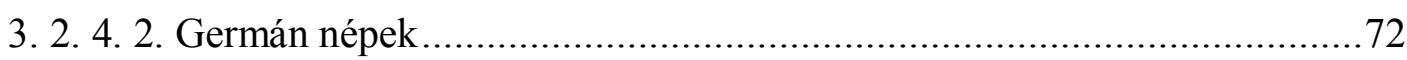

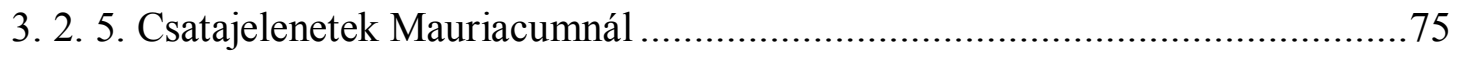

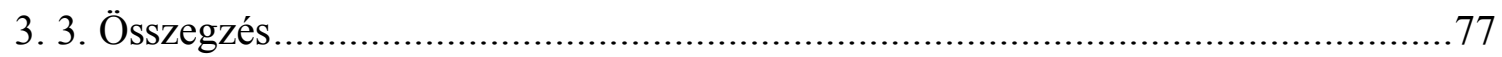

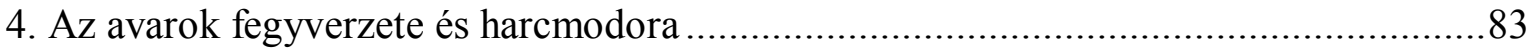

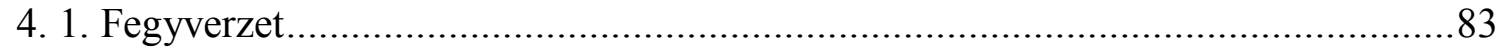

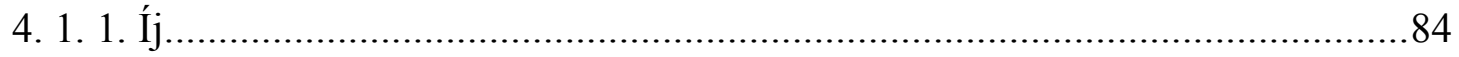

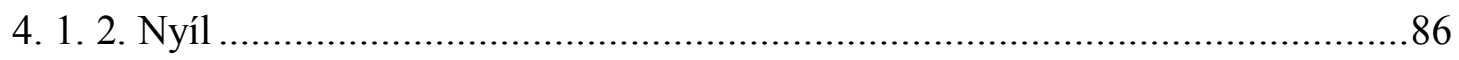

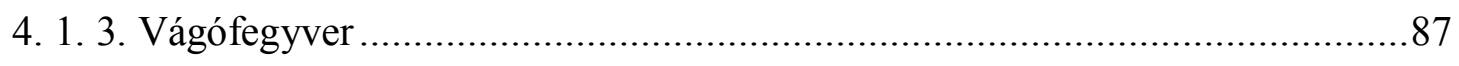

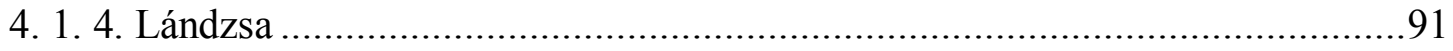

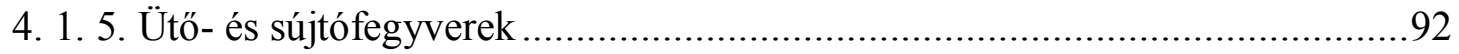

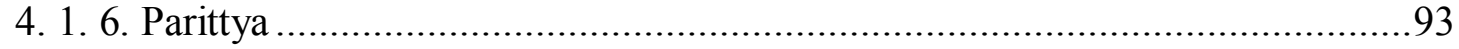

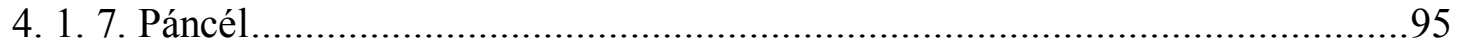

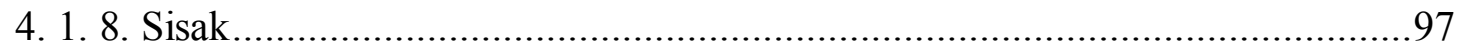

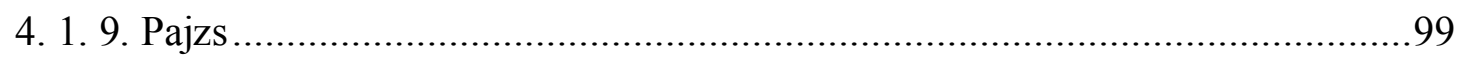

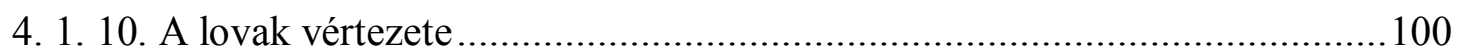

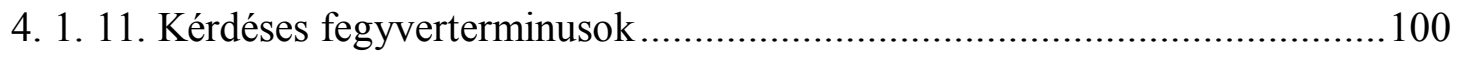

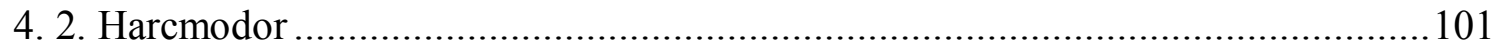

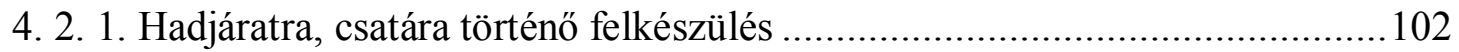

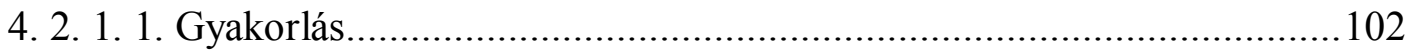

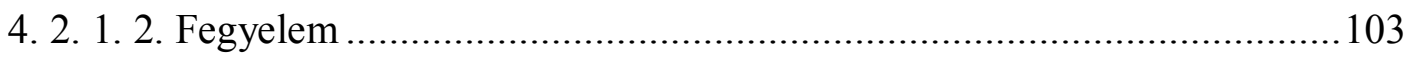

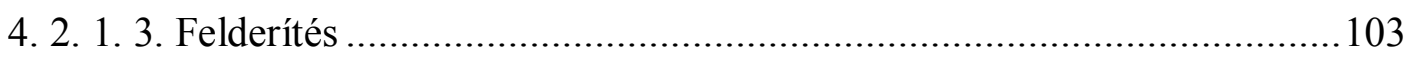

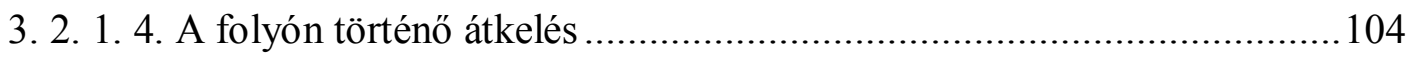

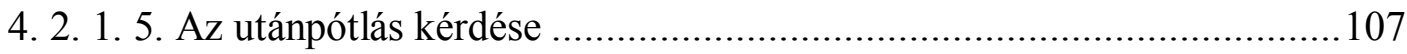

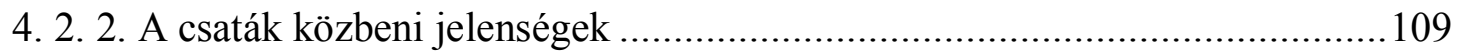

4. 2. 2. 1. Hadrend, létszám ........................................................................ 110

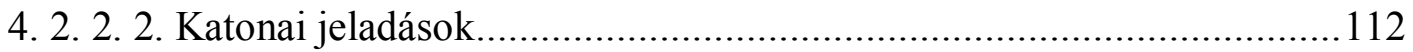

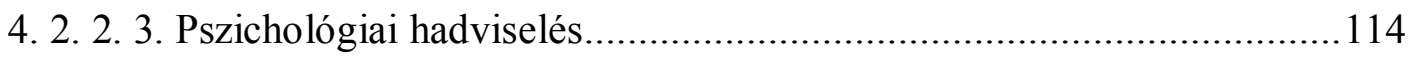

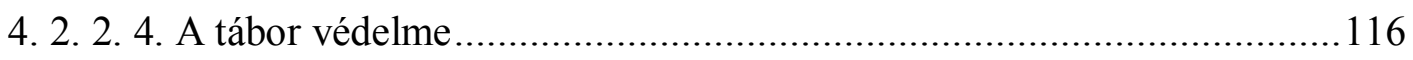

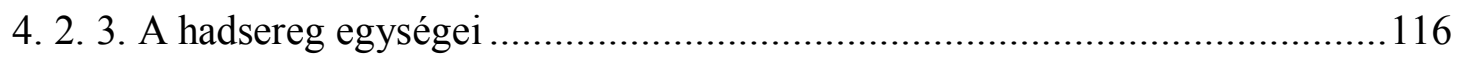

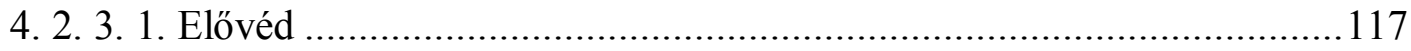




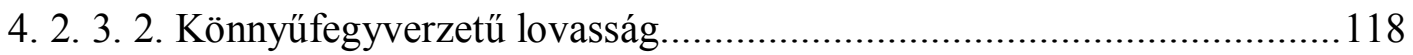

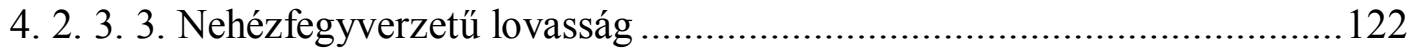

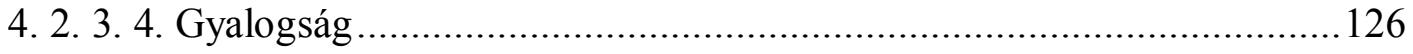

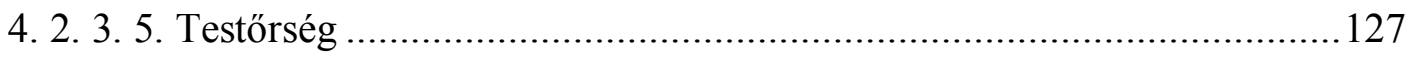

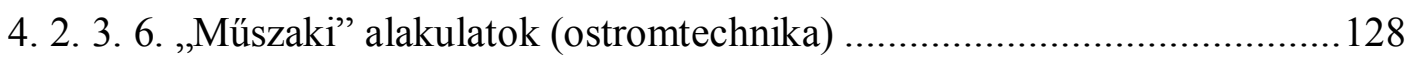

4. 2. 4. Az alávetett segédnépek szerepe ........................................................... 139

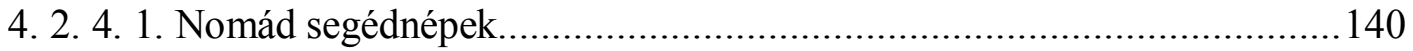

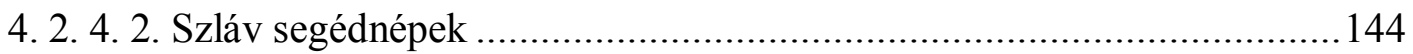

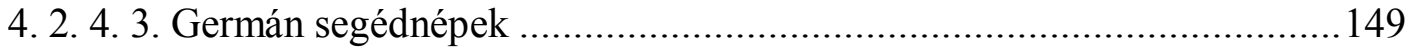

4. 2. 5. Csatajelenetek Priskos 599-es hadjáratából ............................................. 152

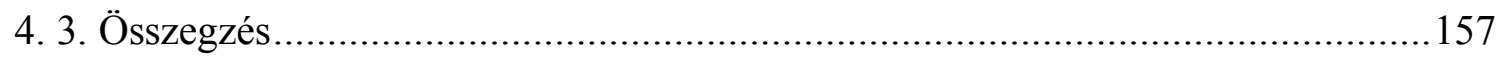

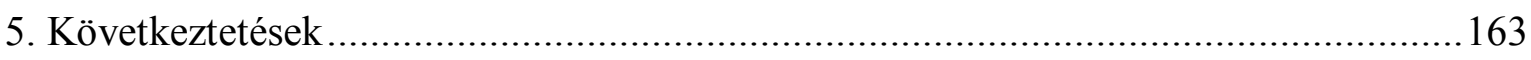

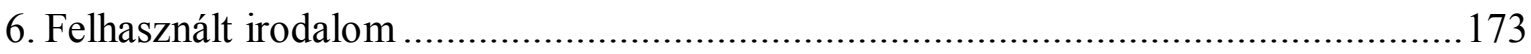

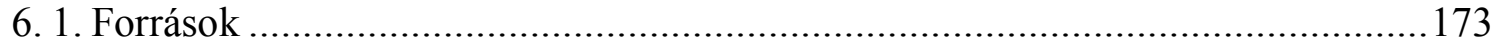

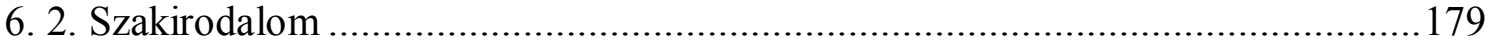

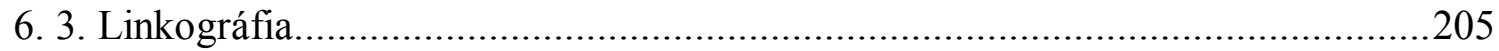

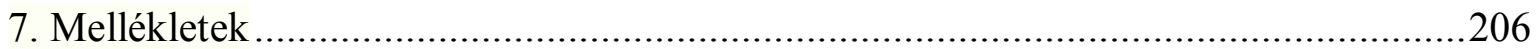




\section{Bevezetés}

A nomád népek harcmodora kapcsán az írott források többsége elsősorban a könnyüfegyverzetü lovasság jelentőségét emeli ki. Az elsőként Hérodotosnál megfogalmazott jellemzőket, köztük a lovas-íjász harcmodor leírását a későbbi szerzők átvették, és a letelepült civilizációk látókörében aktuálisan megjelenő nomád népekre alkalmazták a középkor folyamán. A korabeli szerzők által sokszor használt toposzokat a modern kutatás is sokáig elfogadta és hangsúlyozta a nomád népek harcmodorára vonatkozólag. Bár igaz, hogy a nomádok többségénél a könnyüfegyverzetü lovasság volt a meghatározó a hadászati taktikában, és a korabeli külső szemlélők számára is ez a harcmodor volt az újdonság. Így ezt jobban kiemelték a nomád népek esetében a kútfőkk. Emellett azonban az írott és régészeti források, valamint képi ábrázolások tüzetesebb vizsgálata során megállapítható, hogy a könnyüfegyverzetü lovasság mellett a nomád népek taktikája kapcsán nehézfegyverzetü lovassággal, gyalogsággal és ostromtechnikával is számolhatunk.

A nomád népek harcmodorát és fegyverzetét összefoglaló első munka U. Kőhalmi Katalin tollából született. A kismonográfia az eurázsiai steppe nomád népeinek fegyverzetét, harcmodorát és lószerszámát vizsgálja korszakokra bontva a Kr. e. 8 . századtól az Árpád-korban a Kárpát-medencébe érkező nomád népek beköltözéséig. A szerző részletesen korszakokra bontva tér ki a fegyver- és lószerszámtípusok fejlődésére, illetve ezeknek a harcmodorra gyakorolt hatására (U. KÖHALMI 1972). A nomád népek harcászatával foglalkozó utolsó átfogó munkát Peter Golden írta, aki a mongolokig bezárólag foglalta össze a téma legfontosabb írott forrásokból származó adatait és szakirodalmát. Összehasonlítva ezt az időszakot a mongol korral, lényegesen kevesebb forrás áll a rendelkezésünkre, így sokkal nehezebb egy átfogó, összegző képet alkotni az eurázsiai steppe nomádjainak harcászatáról. Golden nem korszakokra vagy egyes nomád népekre lebontva ismertette a harcászatukat, hanem a nomád népek harcmodorának bizonyos taktikai, stratégiai elemeit vizsgálta átfogóan az írott források tükrében (például lovasság, gyalogság, ostromtechnika, hadsereg táborának a védelme) (GOLDEN 2002, 105171).

A hunok esetében több, harcmodorukat részletező munka született. Ezek egy része a hunok történetét és/vagy régészeti anyagát összefoglaló munkákban található, harcmodorral foglalkozó fejezet. Emellett a hunok fegyverzetét, harcmodorát feldolgozó önálló munkák is születtek. Thompson a hunok történetét összefoglaló kötetében ismertette 
ezen nomád nép harcmodorát. A szerző elsősorban a hunok könnyűfegyverzetű lovasságát hangsúlyozta (THOMPSON 2003). Otto J. Maenchen-Helfen a hunok harcmodorára csak röviden tér ki, emellett viszont részletesen vizsgálta a fegyverzetüket, főként írott források alapján, de sok esetben a régészet eredményeit is bevonta a kutatásaiba. Maenchen-Helfen a nehézfegyverzetü lovasságra jellemző fegyvereket elemezte behatóbban. Valamint részletesen mutatta be a római seregben feltünő hun zsoldosokra is (MAENCHEN-HELFEN 1997). Bóna István a hunok történetét és a hun kori régészeti anyagot összefoglaló monográfiájában e nomád nép harcmodorát és fegyverzetét is vizsgálta (BóNA 1993a). Tomka Péter pedig a Hunok-gepidák-langobardok címü kötetben külön címszó alatt elemzi a hunok fegyverzetét és harcmodorát. Tomka Péter a hun seregben a könnyüfegyverzetü lovasság mellett feltételezi a nehézfegyverzetű lovasság jelenlétét is. Ezenkívül utal a hadsereg táborának védelmére, a gyakorlásra, a fegyelemre és az utánpótlás problematikájára (TOMKA 1993a; TOMKA 1993b). Valerij L. Nikonorov 2002ben egy terjedelmes orosz nyelvü tanulmányban elemezte a hunok harcmodorára vonatkozó latin és görög nyelvü forrásokat. Ezt a munkáját 2010-ben rövidítve angol nyelven is közzétette. Munkájában részletesen elemezte a hun kori fegyvereket, kitért a forrásokban fellelhető taktikai elemek értékelésére, a hadseregük létszámára, pszichológiai hadviselésükre, a lovaik és lószerszámzatuk jellemzésére. Nikonorov elsősorban a könnyüfegyverzetü lovasság meghatározó szerepét hangsúlyozta munkájában, elveti, hogy lett volna a hun hadseregnek nehézfegyverzetü lovassága (NIKONOROV 2002; NiKONOROV 2010a).

Az avarok harcmodorával és fegyverzetével foglalkozó tanulmányokat elsősorban az e nomád nép történetét összefoglaló monográfiákban találjuk. Ilyen munkák születtek Walter Pohl, Bóna István és Avenarius tollából (AvenARIUs 1974; BóNA 1984; POHL 1988. Legutóbb Csiky Gergely elemezte az avarok harcmodorát a szúró- és vágófegyverek összegyüjtésével és tipológizálásával foglalkozó doktori disszertációjában (CSIKY 2012). Az avar korral foglalkozó történészek többsége elemezte az avar hadsereg szerkezetét, felépítését és taktikáját, melynek során megállapították, hogy az avarok harcmodora főként távolharcra (ij-, nyílhasználatára) épült, és jellegzetességük a nomádokra általában jellemző gyors, rajtaütésszerü támadás, bekerítés. Emellett a szerzők megemlítették a nehézfegyverzetű lovasságot is. Az avarok harcmodorának vizsgálata során megkerülhetetlen munka Szádeczky-Kardoss Samu avarok történetével foglalkozó forrásgyüjteménye, amelyben az avarok délorosz steppei megjelenésétől az Avar Kaganátus bukásáig terjedő időszak forrásainak fordításai és kommentárjai találhatók. Az 
avar fegyverzet és harcmodor kutatásának fontos része Maurikios avarokra vonatkozó részeinek bevonása a kutatásba (SZÁDECZKY-KARDOSS 1998). Darkó Jenő foglalkozott ezzel a témával elöször részletesebben (DARKÓ 1934, 3-40; DARKÓ 1935, 444-469; DARKÓ 1937, 119-147. Majd pedig Szádeczky-Kardoss Samu egy magyar és egy német nyelvü tanulmányában elemezte Maurikios hadászati munkájában az avarok harcászatára és életmódjára vonatkozó részekkel (SZÁDECZKY-KARDOSS 1983, 317-326; SZÁDECZKYKARDOSS 1986, 205-213).

Doktori disszertációm célja a hun és az avar hadsereg fegyverzetére és harcmodorára vonatkozó írott források elemzése. Egyrészt a vizsgált népekre vonatkozó fegyverterminusok összegyüjtése, értelmezése (esetenként régészeti anyaggal való összevetése), másrészt a harcmodorukra vonatkozó leírások összegyüjtése, elemzése. Különösen az olyan területekre fókuszálva (például nehézfegyverzetü lovasság, gyalogság, ostromtechnika), amely területeket kevésbé emelték ki eddig a nomád népek esetében. A dolgozatnak nem célja a régészeti anyag összegyüjtése, értékelése és tipológizálása, amely szétfeszítené ezen munka kereteit. Elsősorban az írott forrásokból nyerhető információk alátámasztására, illetve cáfolására használom fel a régészeti anyagból származó adatokat.

Doktori értekezésem az írott források általános ismertetésén kívül két nagy fejezetből áll, amelyek a hunok és az avarok fegyverzetével és harcmodorával foglalkozik. Mindkét fejezetben először e két nomád nép fegyverzetének a vizsgálatára térek ki, összegyüjtve a hunok és az avarok fegyvereire vonatkozó föként latin és görög nyelvü terminusokat, illetve az írott forrásokban található, fegyverzetükre vonatkozó jellemzéseket. A felsorolt forrásokban a főként görög és a latin nyelvü szerzők a hunok és az avarok fegyvereire a saját hadseregükben elterjedt terminusokat használták. Tehát feltételezhető lenne az, hogy a görög és latin fegyverelnevezés az avarokra vonatkozólag is ugyanolyan rendeltetésű, felépítésű fegyvertípust jelenthetett, mint a bizánciaknál és a nyugat-európai államokban. Ez természetesen elsősorban csak a hadászatban jártas szerzők, hadászati munkák esetében feltételezhető. Más müfajú munkák esetében ezeket a terminusokat csak általános elnevezésként alkalmazhatták, ha volt is konkrét jelentésük, nem mindig ennek megfelelően alkalmazták. A hunokra és az avarokra vonatkozólag is erős forráskritikával kell kezelni ezeket a kifejezéseket, és ezért van szükség több forráscsoport összevetésére (ábrázolások, régészet). A fegyverzet elemzését követően e két nomád nép harcmodorára térek ki. Külön alfejezetekben tárgyalom a hadjáratra, csatára történő felkészüléshez sorolható jelenségeket, amiben a gyakorlás, a fegyelem, a felderítés, a jóslás, a folyón történő átkelés és az utánpótlás kérdésének problematikáját vizsgálom. A 
csaták közben megfigyelhető jelenségek közül e nomád népek hadseregeinek a hadrendjét, a létszámát, katonai jeladásaikat, pszichológiai hadviselésük különböző formáit és hadseregeik táborának védelmére vonatkozó híradásokat elemzem. Külön alfejezetben térek ki a hadseregeik különbözői egységeinek vizsgálatára: elővéd, könnyüfegyverzetü lovasság, nehézfegyverzetü lovasság, gyalogság, testőrség és müszaki alakulatok (ostromtechnika). Külön fejezetben vizsgálom meg a hunok és az avarok alávetett segédnépeire vonatkozó adatokat. Mindkét nomád nép harcmodorával foglalkozó utolsó alfejezetben egy-egy jelentős csata jeleneteit elemzem: a hunok esetében a mauriacumi csatát, az avarok esetében pedig Priskos bizánci hadvezér 599-es avarok ellen vezetett hadjáratát.

Végezetül meg szeretném köszönni a Középkori Egyetemes Történeti Tanszék és a Régészeti Tanszék munkatársainak a támogatását, tanácsait, biztatását, önzetlen segítségét, amivel jelentősen hozzájárultak ahhoz, hogy végül is elkészült ez a munka. Külön köszönöm a témavezetőim segítő útmutatásait, tanácsait, segítségét. 


\section{A korszakra vonatkozó írott források}

A hunok és az avarok fegyverzetére és harcmodorára vonatkozó írott kútfők vizsgálata kapcsán fontos hangsúlyozni, hogy egyik nomád nép esetében sem rendelkezünk belső forrásokkal. ${ }^{1}$ Mindkét nomád birodalom fennállásának időszakában megfigyelhetőek forrásokban gazdagabb és szegényebb időszakok. ${ }^{2}$

A Hun Birodalom esetében az Attila uralkodását megelőző időszakról kevés forrás áll a rendelkezésünkre, ezek is általában rövidebb híradások. Attila időszakáról viszont jelentős mennyiségű anyaggal rendelkezünk, ahogy Schäfer fogalmaz, ez a periódus az írott anyag 90 százalékát teszi ki (SCHÄFER 2001a, 23). A hunok fegyverzetének és harcmodorának a vizsgálatára huszonegy auktor müvét vontam be, melyek döntő többsége görög és latin nyelvü kortárs munka. Ez utóbbi alól csak Tours-i Gergely, Iordanes és Paulus Diaconus történeti munkái és a Suda lexikon a kivételek. A kortárs kútfők közül főként történeti/egyháztörténeti munkák (Olympiodoros, Zosimos, Priskos, Sozomenos, Ammianus Marcellinus, Pseudo-Aurelius Victor), valamint költemények és panegyricusok (Asterios, Claudius Claudianus, Merobaudes, Sidonius Appolinaris, és Pacatus), valamint Szent Ányos legendája és Szent Jeromos két levele állnak a rendelkezésünkre. A latin és a görög nyelvü kútfők mellett három szír (Pseudo-Kallisthenes, Pseudo-Ephraem, Josue Stylita) és egy skandináv (Hervar vagy Heidrik saga) forrás adatából is következtethetünk a hunok fegyverzetére és harcmodorára.

Az Avar Kaganátus korai időszakában, a Bizánci Birodalom elleni hadjáratok időszakától jelentős számú tudósítás áll a rendelkezésünkre. Úgy is fogalmazhatunk, hogy az Avar Kaganátus fennállásának ezen időszaka tekinthető forrásokban a leggazdagabb korszaknak. Ezek döntő többségében természetesen görög nyelvüek. Csak néhány latin forrás áll a rendelkezésünkre, melyek az avarok nyugati kapcsolataira utalnak (például Paulus Diaconus). A 630-as években az Avar Kaganátus elveszítette a térségben betöltött jelentőségét, nagyhatalmi pozícióját. Ezt jelzi például a vendek, dél-szlávok és a délorosz

\footnotetext{
${ }^{1}$ Az avarok régészeti anyagában megtalálhatók rövidebb rovásírásos feliratok, melyeket eddig még nem sikerült egyértelmüen megfejteni a számos, elolvasásukra tett kísérlet ellenére. A leghosszabb ilyen rovásírásos feliratok a szarvasi tütartón és a nagyszentmiklósi kincsen láthatók. Az avarok rovásírására lásd például VÁSÁRY 1972, 335-347; HARMATTA 1985, 57-72; RÓNA-TAS 1985a, 95-98; RÓNA-TAS 1985b, 225248; VÉKONY 1987; SÁNDOR 1997; RÓNA-TAS 2002, 120-129.

${ }^{2}$ Veszprémy László vetette fel legutóbb azt a kérdést, hogy a középkori hadtörténetíráshoz rendelkezésünkre álló forrásanyag mennyire használható. Ugyanis ebben az időszakban szinte egyáltalán nem rendelkezünk „hadtörténeti” forrásanyaggal, különféle műfajú, értékü források részleges adataiból lehet csupán következtetéseket levonni. Veszprémy felhívja a figyelmet arra, hogy ezeket a forrásokat csak kellő forráskritikát alkalmazva, értékelve, elemezve használhatjuk fel (VESZPRÉMY 2006, 517, 523; VESZPRÉMY 2008, 13, 19).
} 
steppei onogundur bulgárok elszakadása, illetve Konstantinápoly 626-os sikertelen ostroma. Ennek következtében az Avar Kaganátus területe visszaszorul a Kárpátmedencébe, és ettől az időszaktól az avarokról megemlékező források száma nagyon csekély. ${ }^{3}$ Az avarokat említő források száma akkor sürüsödik újból, amikor a Kárpátmedence és vele együtt az avarok a frankok látókörébe kerülnek, bár a források száma meg sem közelíti a bizánci-avar háborúk időszakának mennyiségét. A frank-avar háborúk időszakában természetesen a latin nyelvü források a meghatározóak. Az avarok harcmodora és fegyverzete kapcsán huszonnyolc forrást vontam vizsgálat alá, melyek döntő többsége kortárs híradás. Kivételt képez ez alól Paulus Diaconus, Theophanes, Nikephoros Patriarcha, Kónstantinos Porphyrogennétos császár (913-957), Manasses, Zonaras, Plótinos Thessalonikeus, Nikephoros Kallistos Xanthopulos, Konstantinos Akropolités munkái és a Suda lexikon. A kortárs források közül többféle müfajú müvek adatai hasznosíthatók e témában. A hadászati művek közül Maurikios császár (582-602) Stratégikonja, a történeti munkák, krónikák közül Menandros Protéktór, Theophylaktos Simokattés, Chronicon Paschale, Tours-i Gergely és Fredegar müve említhető meg. A költemények közül pedig Corippus, Geórgios Pisidés és Paulinus Aqileiensis szerzeményei sorolhatók fel. A teológiai munkákhoz, szentbeszédekhez, legendákhoz Theodóros Synkellos és Euagrios munkája, Szent Demeter csodái és az Epithapium Geroldi sorolható. A frank-avar háborúk időszakára az évkönyvek közül az Annales regni Francorumot, az Annales qui dicuntur Einhardit és az Annales Laureshamensest érdemes bevonni a vizsgálatba. Szintén erre a korszakra vonatkozóan Alcuin két levelét és egy frank rendeletet (805-ös) fontos kiemelnünk az avarok harcmodora és fegyverzete kapcsán. ${ }^{4}$

\footnotetext{
${ }^{3}$ A bizánci források hiánya azzal is magyarázható, hogy a Bizánci Birodalomra általánosságban jellemző, hogy 7. és a 8. század rendkívül szegényes írott forrásokban (OSTROGORSKY 2003, 97). A 7. század közepén betelepített horvátok és szerbek, majd a század végén a dunai bolgár állam létrejötte miatt megszünt az avarbizánci kapcsolat. Ráadásul a 8. században a bizánci társadalom átalakulása miatt kevesebb történeti mü keletkezett és még kevesebb maradt ránk.

${ }_{4} \mathrm{Az}$ avarok történetére vonatkozó görög és latin nyelvü források gyüjteménye: Glossar zur frühmittelalterlichen Geschichte im östlichen Europa. Hrsg. Ferluga, J. - Hellmann, M. - Ludat, H. Zernack, K. Serie A. Lateinische Namen bis 900, Red. Wojtecki, D., Bd. I., Wiesbaden, 1973-1975; Glossar zur frühmittelalterlichen Geschichte im östlichen Europa. Hrsg: Ferluga, J., Hellmann, M. - Ludat, H. Zernack, K. Serie B. Griechische Namen bis 1025. Red. Fourlas, A. A. - Katzanakis, A. A. Bd. I. Wiesbaden 1988. Az Avar Kaganátusra vonatkozó források magyar fordítása kommentárral: Szádeczky-Kardoss S.: Az avar történelem forrásai 557-töl 806-ig. [Magyar Östörténeti Könyvtár 12.] Budapest 1998. A 9. századi avarokat említő görög nyelvű források bilingvis kiadása : Olajos T.: A IX. századi avar történelem görög forrásai. [Szegedi Középkortörténeti Könyvtár 16.] Szeged 2001.
} 


\section{1. A hunokra vonatkozó írott források}

A görög nyelvü források közül érdemes megemlíteni a 4. század második felében, 5. század első felében élt amaseai püspököt, Asteriost, aki számos szentségmagyarázó beszédet alkotott. A Szent Phókasról írt homíliájában ${ }^{5}$ megemlékezik a Maiotis és a Tanais környékén élő „szkíták” egyik uralkodójáról/vezetőjéről, aki annyira tisztelte ezt a szentet, hogy többek között egy nemesfémböl készült vértezetet küldött a sinopei Szent Phókastemplomba. Ezt a homíliát Asterios 400 táján írhatta, amikor a délorosz steppén a hunok jelenléte volt a meghatározó. Ebből kifolyólag Maenchen-Helfen vetette fel először, hogy ez a bőkezü „szkíta” vezető hun lehetett (MAENCHEN-HELFEN 1997, 249-250; BALDWIN 1991a, 213; KRAFT 1980, 1127-1128). ${ }^{6}$

Szintén kortárs forrás Olympiodoros történeti munkája, a Thébából származó szerző 412-ben követségben járt Donatusnál, a hunok királyánál. Mủvébe természetesen beépítette a saját küldetéséből származó információkat, és kitért a hunok bemutatására is. A szerző munkája nagyon jó forrásértékkel bír, azonban sajnos teljes egészében nem ismerjük, csak töredékei maradtak fenn (THOMPSON 2003, 21). ${ }^{7}$ Olympiodoros múvét jelentős mértékben felhasználta Zosimos és Sozomenos is.

Az 5. század első felében élt szerző, Sozomenos egyháztörténeti munkája 324 és 415 közötti időszakot foglalja magába. Bár a dogmatikai viták megértése és interpretálása nem túlságosan az erőssége az egyháztörténet-írónak (MORAVCSIK 1958, 510-511; BALDWIN 1991b, 1932-1933), ${ }^{8}$ a hunok esetében egy érdekes elbeszélést örökített meg a pányvahasználatukról.

Az 5. század végén/6. század elején alkotó szerző, Zosimos történeti munkája az Augustus uralkodásától 410-ig terjedő időszakot öleli fel. ${ }^{9}$ A hunok korai hadjáratai kapcsán találhatunk információkat a fegyverzetükre és harcmodorukra vonatkozólag (MORAVCSIK 1958, 577-579; BALDWIN 1991d, 2231).

\footnotetext{
${ }^{5}$ Eredeti, görög nyelvủ kiadása S. Patris nostri Asterii Amaseae episcopi. Ed. Combefis, F. [Graecolatinorum patrum bibliothecae novum auctarium] Parisiis 1648 .

${ }^{6}$ A hunok keresztény hitre térésére utaló, 4. század legvégére és az 5. század elejére datálható, egymásnak ellentmondó írott források adataiból arra következtethetünk, hogy a térítő tevékenységek ellenére a hunok többsége valószínűleg ugyanúgy pogány maradt, mint amikor a 4. század második felében megérkeztek Kelet-Európába. Azonban az egyházi írók beszámolóiból kisebb térítési eredményekre lehet következtetni (NAGY 2009, 32).

${ }^{7}$ Mérvadó szövegkiadása és angol fordítása The Fragmentary classicising Historians of the later Roman Empire. Eunapius, Olympiodorus, Priscus and Malchus. I-II. Ed. Blockley, R. C. [Classical and Medieval texts, Papers and Monographs 6.] Liverpool 1981.

${ }^{8}$ Mérvadó szövegkiadása Sozomenus. Kirchengeschichte. Hrsg. Bidez, J. - Hansen, G. C. Berlin 1960.

${ }^{9}$ Mérvadó szövegkiadása Zosimi Historia nova. Ed. Mendelssohn, L. Leipzig 1887; német nyelvú fordítása Zosimos. Neue Geschichte. Hrsg. Rebenich, S. [Bibliothek der Griechischen Literatur 31.] Stuttgart 1990.
} 
Olympiodoroshoz hasonlóan Priskos Rhétor is követségben járt a hunoknál: 449ben Maximianus titkáraként Attila udvarában szerzett rendkívül értékes tapasztalatokat. Történet munkája szintén csak töredékesen maradt fenn, sajnos a hunok hadjárataival, harcmodorával, fegyverzetével foglalkozó passzusok nagy része nem maradt ránk, ${ }^{10}$ azonban így is sok információt szolgáltat szerzőnk ebben a témában is a hunokról. A fennmaradt, hadászattal foglalkozó részeivel szemben azonban felmerül az a vélemény is, hogy túlságosan irodalmiak, és kevés a valóságtartalmuk (SZŐM 134; BALDWIN 1980, 18 61; BALDWIN 1991c, 1721).

Az egyik legkésőbbi forrásunk a Suda lexikon, melyet valószínüleg a 10. század legvégén állítottak össze. Az alfabetikus beosztású munka számos nehéz nyelvtani alakot, ritka szavakat és szólásokat magyaráz meg, valamint személyeket, helyneveket, szituációkat jellemez. ${ }^{11}$ A forrás sok korábban élt antik és kora középkori auktor munkájából származó adatot ötvöz egybe, közöttük például Priskos mára elveszett történeti művéből (MORAVCSIK 1958, 512-513; KAZHDAN 1991c, 1930-1931).

A latin nyelven alkotó szerzők közül a legkorábbi auktoraink közé tartozik Pacatus Drepanus, akinek egy I. Theodosiust dicsérő beszéde maradt fenn. A szerző a római császár dicső tetteinek felsorolásában megemlíti a trónbitorló Maximus legyőzését is. ${ }^{12}$ Ezen esemény kapcsán tünnek fel a forrásban a hunok is (NIXON 1987, 1-11; MAGUINNESS 1996, 1105).

Szintén kortárs auktor Ammianus Marcellinus római történetíró, aki a római császárok tetteit bemutató munkájában egy külön részt szentel a hunok etnográfiai jellegü jellemzésének. Ha a hadászati, taktikai szempontból vizsgáljuk meg a munkáját, akkor megállapítható, hogy már müfajából adódóan sem tekinthető hadászati munkának. Ennek ellenére Ammianus viszonylag jól informált haditechnikai témában, bár bizonyos kérdésekben korlátozottak a szerző képességei (AUSTIN 1979, 164-165). ${ }^{13}$ A hunokra vonatkozóan azonban nagyon kevés valós információval rendelkezett, többnyire teljesen

\footnotetext{
${ }^{10}$ Mérvadó szövegkiadása és angol fordítása The Fragmentary classicising Historians of the later Roman Empire. Eunapius, Olympiodorus, Priscus and Malchus. I-II. Ed. Blockley, R. C. [Classical and Medieval texts, Papers and Monographs 6.] Liverpool 1981.

${ }^{11}$ Mérvadó szövegkiadása Suidae Lexicon I-V. Ed. Adler, A. [Lexicographi Graeci 1.] Stuttgart 1967-1971.

${ }^{12}$ Latin nyelvủ kiadása Latini Pacati Drepanii Panegyricus Theodosio Augusto Dictus. Altorphium 1750; angol nyelvü fordítása Pacatus Panegyric to the Emperor Theodosius. Trans. Nixon, C. E. V. [Translated Texts for Historians. Latin Series 2.] Liverpool 1987.

${ }^{13}$ Mérvadó szövegkiadása Ammiani Marcellini. Rerum gestarum libri qui supersunt II. Ed. Seyfarth, W. [Bibliotheca Scriptorum Graecorum et Romanorum Teubneriana] Leipzig 1978; magyar nyelvủ fordítása Ammianus Marcellinus. Róma története. Ford. Szepesy Gy. Budapest 1993.
} 
negatív, primitív képet fest róluk, és más nomád népekre is használt toposzokkal jellemzi őket (RICHTER 1974, 343-377; KING 1987, 77-95).

Claudius Claudianus, a 4. század második felében élt költő In Rufinum címü költeményében található néhány adat a hunok harcmodorára vonatkozóan. Az alexandriai görög származású költő a kései császárkor egyik legnagyobb költője volt. A Rufinus ellen címü, ${ }^{14}$ Rufinust támadó művében egyértelműen Stilicho mellett állt ki (KURZ 1983, 2130 2131; MEZEI 1988, 243-244; NÉMETH 1998, 328). ${ }^{15}$ A szerző néhány sorban emlékezik meg a hunokról, akikről igencsak negatív képest fest, legtöbbször toposzokat alkalmaz rájuk: ,étkük a harc, pofájuk rút.”

Szintén a 4. század második felében élő történetíró, Aurelius Victor nevéhez kötik az Epitomae de Caesaribus címü munka megírását, azonban ez téves következtetés, valódi szerzője ismeretlen. A munkára jellemző a tömörség, és nem mindig megbízható adatokat szolgáltat (MCDONALD-SPAWFORTH 1996, 222). ${ }^{16}$ A hunok harcmodorára vonatkozóan csak nagyon kevés információt ad számunkra.

A 4. század második és az 5. század első felében élt Szent Jeromos számos munkája közül a levelezését érdemes kiemelnünk a hunok harcmodora szempontjából. Az egyházatya, teológus közel százhúsz levele közül kettőben említi meg a hunokat (FRANK 1991, 2-3). ${ }^{17}$ Annak ellenére, hogy kortárs szerzőről van szó, csekély forrásértékkel bír e két írása a hunokra vonatkozólag, lényegében démonizálja a 4. század második felében Európában megjelenő nomád népet. Számos toposzt tartalmaz ez a két levele a hunokra vonatkozóan, és főként olyan kontextusban jeleníti meg őket, amelyben kiemeli a rómaiak jelentőségét, kultúráltságát a „barbár, primitív” hunokkal szemben.

\footnotetext{
${ }^{14}$ Mérvadó szövegkiadása Claudian's in Rufinum. Ed. Levy, H. L. [Philological Monograps of the Americn Philological Association 30.] Princeton 1971; magyar nyelvü fordítása Claudius Claudianus versei. Ford. Mezei B. Budapest 1988.

${ }^{15}$ A Rufinus és Stilicho közötti ellentét főként Nagy Theodosius azon döntésén alapult, mely szerint két fia között felosztotta két részre a Római Birodalmat. Stilicho és támogatói Rufinussal ellentétben ellenezték a döntést, többek között azért, mert véleményük szerint egy megosztott birodalom kevésbé tud majd ellenállni a „barbár” támadásoknak. Ezt a költeményt Rufinus bukása után két évvel, 397-ben olvasták fel. Emellett kiemelendő, hogy a görög származású költőnek egyik pártfogója volt Stilicho, számos költeményében dicsőítette a római hadvezért (MEZEI 1988, 243-244; NÉMETH 1998, 328)

${ }^{16}$ Mérvadó szövegkiadása Sexti Aurelii Victoris Liber de Caesaribus. Praecedunt Origo Gentis Romanae et Liber de Viris Illustribus Urbis Romae subsequitur Epitome de Caesaribus. Rec. Pichlmayr, Fr. [Bibliotheca Scriptorum Graecorum et Romanorum Teubneriana] Leipzig 1970.

${ }^{17}$ Mérvadó szövegkiadása Saint Jérôme. Letters III-IV. Texte établi et traduit par Labourt, J. Paris 1953; magyar nyelvü fordítása Szent Jeromos. Levelek. Ford. Adamik T. - Puskely M. - Takács L. Budapest 2005.
} 
Az 5. században élt frank származású hispániai Merobaudes költő az Aetius 446-os harmadik consulságának tiszteletére írt panegyricusában ${ }^{18}$ említi meg a Római Birodalomra támadó hunok felszerelését, fegyverzetét. A szerző szkítának nevezi a hunokat. Bár költeményének ezen részében megfigyelhető Claudius Claudianus és Statius munkáinak a hatása, ennek ellenére nem vethető el teljesen a forrásértéke. Aetius jól ismerte a hunokat, így Merobaudes mint Aetius „udvari költője” nem valószínü, hogy teljesen valótlan adatokat fúzött volna bele a beszédébe erről a nomád népről (LENZ 1931, 1039-1047; Olajos 1966, 172-173, 181, 184; Olajos 1970, 863-866; ClOVER 1971, 7 10; GRUBER 1993, 542).

Szintén 5. századi szerzőnk Sidonius Appolinaris, aki politikai tisztségeket töltött be Rómában és Galliában, majd pedig Arvernum püspöke lett. Sidonius két költeményében is megemlíti a hunokat, utal azok fegyverzetére és harcmodorára (GRÜNBECK 1995, 1834 1835). ${ }^{19}$ A szerző egyrészt a hunok általános jellemzése kapcsán, legtöbbször toposzokat alkalmazva utal a fegyverzetükre, harcmodorukra. Másrészt pedig konkrét esemény kapcsán említi meg a hunok fegyverzetét utalva a harcmodorukra, illetve egy esetben a folyón történő átkelés módjára is.

A kései források közül kiemelendő jelentőségű a 6. századi Iordanes Geticája, ${ }^{20}$ amely a hunok története kapcsán több fontos információt hordoz. A gót származású szerző számos auktor művét felhasználta a Geticában (például Cassiodorus, Ammianus Marcellinus, Tacitus stb.). A hunok története szempontjából viszont a legfontosabb, hogy Priskos elveszett munkájának egyes részleteit is megőrizte. Ezenkívül a hunokra vonatkozóan néhány adatot találunk Iordanes másik munkájában, a Romanában ${ }^{21}$ is (SCHWARCZ 1991, 626-627; CHRISTENSEN 2002, 84-123; HORVÁTH 2005, 1-12).

Szintén a 6. században alkotott Tours-i Gergely (Gregorius Turonensis) ókeresztény író, püspök, aki a világ teremtésétől 591-ig terjedő időszakot magába foglaló tízkötetes

\footnotetext{
${ }^{18}$ Mérvadó szövegkiadása és fordítása Flavius Merobaudes. Ed., Trans. Clover, F. M. [Transactions of the American Philosophical Society 61.] Philadelphia 1971; magyar nyelvü fordítása Olajos T.: Merobaudes müvei. Antik Tanulmányok 13 (1966), 172-188.

${ }^{19}$ Latin-angol nyelvú, bilingvis kiadása Sidonius. Poems and letters. I. Trans. Anderson, W. B. [The Loebl Classical Library] London-Cambridge 1965.

${ }^{20}$ Eredeti címe De origine actibusque Getarum (IORDANES, Getica vö. SzKRZSINSZKAJA 1960, 131). Mérvadó szövegkiadása Iordanis Romana et Getica. In: Monumenta Germaniae Historica. Auctorum Antiquissimorum 5. Rec. Mommsen Berolini 1961, ${ }^{2}$ 1-52. Latin-orosz nyelvü kiadása Иордан о происхождении и деяниях Гетов. Вступительная статья, перевод, комментарий Скржинской, Е. Ч. Москва 1960; magyar nyelvủ fordítása Iordanes. Getica. Közreadja Kiss M. Budapest 2005.

${ }^{21}$ Eredeti címe De summa temporum vel origine actibusque gentis Romanorum (IORDANES, Romana). Mérvadó szövegkiadása Iordanis Romana et Getica. In: Monumenta Germaniae Historica. Auctorum Antiquissimorum 5. Rec. Mommsen Berolini 1961, ${ }^{2} 1-52$.
} 
Historia Francorum című történeti munkájában néhány helyen említi a hunokat. ${ }^{22}$ A kései szerző a galliai hadjárat kapcsán utal a hunokra, főként az ostromtechnikájukról találunk benne használható adatokat (ANTON 1989, 1679-1681; ADAMIK-MEZEI 2010, 35-78).

Szent Ányos (Anianus) legendája a 4. század második felében, 5. század első felében élt (358-453) orléans-i püspök életét örökíti meg. A forrás szerint székvárosa a hunok támadásakor 451-ben az ő imádsága révén menekült meg. Sajnos az eredeti mủ nem maradt ránk, a fennmaradt változat 8-9. századi lehet (LOYEN 1969, 64-74; PoULIN 1980, $644) .^{23}$

Kevés információt szolgáltat számunkra a hunok fegyverzetére, harcmodorára vonatkozóan a 8. századi történetíró, Paulus Diaconus. A langobard származású szerző több történeti munkát írt, illetve kivonatolt korábbi szerzők müveiből. Köztük a Historia Romana címü munkát, ${ }^{24}$ melyben a hunok kapcsán a mauriacumi csata ismertetésekor találunk adatokat a hun sereg táborának a védelméről (GASPARRI 1993, 1825-1826; SZŐM 168-169).

A hunok fegyverzetéröl, harcmodoráról három szír szerző munkájában is találunk információkat. Ebből két szerzőnél, Pseudo-Kallisthenesnél és Pseudo-Ephraemnél a szír Nagy Sándor-legenda prózai, illetve verses feldolgozásában találhatók a hunokra vonatkozó adatok, amiket a Góg és Magóg ellen Nagy Sándor által emelt kapu építésének történetét foglalják össze. Pseudo-Kallisthenes és Pseudo-Ephraem munkáikban igencsak negatív színben, toposzokkal tarkítva mutatják be ezt a nomád népet, azonban megemlékeznek a hunok egyes szokásairól, babonáiról is. Eléggé szemléletesen ábrázolják, hogy a Kaukázuson túl, a perzsa és római tartományokban megjelenő „barbár” sereg milyen páni félelmet okozott (KMOSKÓ 2004, 28-34; DiCKENS 2008, 126-127). A 6. századi Josue Stylita müve egy nagyobb, terjedelmesebb történeti munkában, PseudoDionysios krónikájában maradt fenn. A 6. századi szír krónika a hunoknak az egykori Mezopotámia területére történő betöréseiről emlékezik meg (KMOSKÓ 2004, 48-49; DiCKENS 2008, 86-87). A hunok fegyverei közül e három szerző erőteljesen hangsúlyozza

\footnotetext{
${ }^{22}$ Mérvadó szövegkiadása Gregorii Episcopi Turonensis. Historiarum libri decem I-V. Ed. Buchner, R. [Ausgewählte Quellen zur Deutschen Geschichte des Mittelalters] Berlin 1967; magyar nyelvü fordítása Tours-i Gergely. Korunk története. A frankok története. Ford. Mezei M. - Adamik T. Pozsony 2010.

${ }^{23}$ Mérvadó szövegkiadása Incipit virtus Sancti Aniani episcopi quemadmodum civitatem Aurelianus suis orationibus a Chunus liberavit. In: Monumenta Germaniae Historica. Scriptorum rerum Merovingicarum 3. Passiones Vitaeque Sanctorum Aevi Merovingici Et Antiquiorum Aliquot. Ed. Krusch, B. Hannoverae 1896, $108-117$.

${ }^{24}$ Mérvadó szövegkiadása Pauli Diaconi. Historia Romana. Ed. Crivellucci, A. [Fonti per la Storia d'Italia. Scittori 7.] Torino $1960 .^{2}$
} 
a pányva használatát, valamint Pseudo-Kallisthenes és Pseudo-Ephraem munkájában a pszichológiai hadviselésről is találunk adatot. ${ }^{25}$

A hunok hadszervezetéről fontos információkat nyújt egy skandináv saga, a Hervar vagy Heidrik saga (Hervarar saga ok Heiðreks). Ez a forrásunk viszonylag kései, 12. századi keletkezésü, de különféle régebbi mondákat tartalmaz. Ez az izlandi saga öt változatban maradt fenn, ezek néhány dologban különböznek csak egymástól. ${ }^{26}$ Ebben a mondában található a számunkra a hunok szempontjából fontos, a gótok és a hunok közötti 4. századi háború leírása is (ToLKIEN 1960, XXI-XXIX).

\section{2. Az avarokra vonatkozó írott források}

Az avarok fegyverzetére, harcmodorára vonatkozó adatokat elsősorban bizánci és frank szerzők szolgáltatják. A korai avar korra főként görög (kivétel például Paulus Diaconus), a késő avar korra pedig főként latin nyelvü (kivétel Euagrios) források állnak rendelkezésünkre.

A görög nyelvü források közül legfontosabb az avarok harcmodorára és fegyverzetére a Stratégikon címü hadászati kézikönyv; ${ }^{27}$ a mü szerzőjének kilétét nem lehet egyértelműen eldönteni. Egy kéziratban Urbikios, egy száz évvel korábban élt, haditaktikával is foglalkozó író neve tünik fel, a többiben viszont Maurikios bizánci császár nevéhez kötődik ez a hadászati munka. Az viszont kérdéses, hogy a bizánci császár maga írta, vagy az ő ösztönzésére és pártfogása alatt állította-e össze valaki. Legvalószínűbb, hogy Maurikios „megrendelésére” és irányításával több bizánci katonatiszt készíthette el ezt a hadászati munkát (DENNIS-GAMILLSCHEG 1981, 15-18; SZÁDECZKY-KARDOSS 1998, 80; KÁKÓCZKI 2012, 279-280). A Stratégikon a korai bizánci hadászat egyik legmeghatározóbb, legjelentősebb munkájának tekinthető. ${ }^{28} \mathrm{~A}$ hadászati munka keletkezése valamikor a 600 körülre, mindenképpen 640 előttre tehető. Írója a bizánci hadászati szerzők zömétől eltérően elsősorban kora valódi viszonyait ábrázolta, a

\footnotetext{
${ }^{25}$ Mérvadó szövegkiadásuk és angol nyelvű fordításuk Dickens, M.: Turkāyēe. Turkic People in Syirac Literature Prior to the Seljüks. Dissertation submitted for the degree of Doctor of Philosophy. Manuscript. Cambridge 2008. Magyar nyelvü fordításuk Kmoskó M.: Szír írók a steppe népeiröl. Szerk. Felföldi Sz. [Magyar Östörténeti Könyvtár 20.] Budapest 2004.

${ }^{26}$ Mérvadó szövegkiadása és angol nyelvü fordítása Saga Heiđreks konungs ins vita. The Saga of King Heidrek the Wise. Trans. Tolkien, C. London 1960.

${ }^{27}$ Mérvadó szövegkiadása és német fordítása: Mauricii Strategicon - Das Strategicon des Maurikios. Ed. Dennis, G. T. [Corpus Fontium Historiae Byzantinae 17.] Vindobonae 1981.

${ }^{28}$ VI. Bölcs Leó bizánci császár Taktika címü hadászati munkájának megírása során többek között jelentős mértékben felhasználta a Stratégikont is (MORAVCSIK 1951, 334-353).
} 
munkából egyértelműen kitűnik, hogy a hadászatban jártas szerző/szerzők állította/állították össze, bár fellelhető benne néhány irodalmi reminiszcencia, toposz is. Azt azonban nehéz megállapíthatni, hogy a Stratégikon szerzője/szerzői mely korábbi műveket használta/használták fel a munka megírásakor, ugyanis nem nevezte/nevezték meg a forrásokat. Feltételezhető, hogy Homéros, Polybios, Aelianus Tacitus és Vegetius munkái jöhetnek szóba (DENNIS-GAMILLSCHEG 1981, 15-18; SZÁDECZKY-KARDOSS 1998, 80; KÁKÓCZKI 2012, 280). Az avarokra, türkökre vonatkozó részei sok értékes adatot szolgáltatnak a harcmodorukról, emellett azonban több antik irodalmi toposzt is tartalmaznak. Az avarok fegyverzete kétféle kontextusban fordul elő a forrásban: az avarok általános jellemzése kapcsán és olyan szempontból, hogy mely hadászati újítást érdemes átvennie a bizánci hadseregnek. ${ }^{29}$

Az avarok korai történetéröl egyik legfontosabb forrásunk a 6. század második felében élt Menandros Protéktór Historiai című, nyolc könyvből álló munkája. ${ }^{30}$ A Maurikios császár idején élt szerző Justinianos utolsó éveit, II. Justinus és Tibérios császár uralkodását (558-582) dolgozza fel hitelesen, ám sajnos munkája csak töredékesen maradt fenn (MORAVCSIK 1958, 422-423; BLOCKLEY 1985, 1-30; SZŐM 139). A korai bizánciavar háborúk időszakára vonatkozóan találunk a munkájában adatokat az avarok harcmodoráról. Menandros elsősorban az avarok fegyverzetéről, folyón történő átkelésüknek és utánpótlásuknak típusairól szolgáltat megbízható adatokat. Továbbá a bizánci szerző utal az avar hadsereg létszámára, gyalogságára és segédnépeire.

A Herakleios császár (610-641) idején alkotó Theophylaktos Simokattés legjelentősebb mủve az Oikumeniké historia, ${ }^{31}$ ez a nyolc könyvből álló történeti munka

\footnotetext{
${ }^{29}$ Maurikios hadászati mủve leggyakrabban abban a kontextusban tünik fel a magyar kutatásban, hogy Bölcs Leó mennyire támaszkodhatott a Stratégikonra a honfoglaló magyarok harcmodorának, fegyverzetének leírásakor a Taktika címü munkájában. Maurikios XI. fejezet avarokra (türkökre) vonatkozó részlete és Bölcs Leó XVIII. fejezet magyarokra vonatkozó részének összehasonlítása kapcsán több vélemény is született. Például Gyomlay Gyula a két forrás pontos egybevetése alapján arra az eredményre jutott, hogy Bölcs Leó „,szolgai” módon egyszerủen kiírta forrását, a 6 . századi avarok és türkök hadi szokásait egyszerủen átvitte a 9. századi magyarokra, s így tudósításai teljesen értéktelenek (GYOMLAY 1902). Ezzel szemben például Darkó Jenő azt igyekezett bizonyítani, hogy Bölcs Leó Maurikios tudósításait tudatosan írta át, mert felismerte, hogy a magyarok ugyanazt a taktikát alkalmazták, mint a 6. századi avarok, türkök (DARKÓ 1915, 119-121). Moravcsik Gyula e két szélsőséges nézettel szemben egy köztes véleményt fogalmazott meg, szerinte Bölcs Leó nem ,értelmetlen, szolgai” másoló, de nem is tekinthető a modern értelemben vett filológusnak. Moravcsik úgy véli, hogy a bizánci császár által megrajzolt kép egészében véve hitelesnek tekinthető, azzal a fenntartással, ez inkább tipikus, mintsem egyéni (MORAVCSIK 1951, 352-353). A témában lásd részletesebben B. SzABÓ 2010.

${ }^{30}$ Mérvadó szövegkiadása és angol fordítása The History of Menander the Guardsman. Trans. Blockley, R. C. [ARCA 17.] Ottawa 1985.

${ }^{31}$ Mérvadó szövegkiadása Theophylacti Simocattae. Historia. Ed. Boor, C. D. rev. Wirth, P. Stutgardiae 1972; magyar nyelvű fordítása Theophülaktosz Szimokattész. Világtörténelem. Ford. Olajos T. [Magyar Östörténeti Könyvtár 26.] Budapest 2012.
} 
Maurikios császár (582-602) uralkodási idejét dolgozza fel. A szerző elsősorban két fő témára fókuszált: az avarokkal és szlávokkal szembeni balkáni hadviselésre, valamint a perzsák elleni keleti háborúkra. ${ }^{32}$ Pozíciója folytán hozzájuthatott számos okmányhoz és feljegyzéshez, és ebből kifolyólag sok értékes adatot tartalmaz a 6-7. századi délorosz steppei népekről, köztük az avarokról is. Emellett azonban megjegyzendő, hogy a szerző tekervényes stílusa folytán a 7 . század első felében készült munka bizonyos részletei gyakran nehezen értelmezhetőek, és időnként datálási problémák is felmerülnek a forrás kapcsán (MoRAVCSIK 1983, 544-545; WhITBY-WHITBY 1986, xvii-xxv, xxvii-xxviii; SZÖM 140; OLAJOS 2012, 11-29). Az avarok harcmodora és fegyverzete szempontjából Maurikios Stratégikon címü munkája után az egyik legfontosabbnak tekinthető, annak ellenére, hogy a különböző csataleírások alkalmával bőségesen használ antik irodalmi mintákat, toposzokat, és kevésbé tér ki az avarok jellemzésére. Számos adatot közöl az avarok különböző fegyvertípusaira, a csatára történő felkészülés különböző elemeire (felderítés, folyón történő átkelés), a csatarendjükre, a hadsereg létszámára, a táborának a védelmére, valamint elővédjükre és ostromtechnikájukra vonatkozólag.

Geórgios Pisidés, Herakleios császár uralkodása (610-641) idején élt költő, a Hagia Sophia diakónusa jambikus trimeterekben írt történelmi költeményét „Avar háború” (Bellum Avaricum) címen idézi a tudomány. ${ }^{33}$ A mủ Konstantinápoly 626-os ostromának részletes elbeszélésén túl megemlíti az avarok Türk Birodalomból való kiválását és európai honfoglalásukat is (MORAVCSIK 1958, 288-289; SZŐM 143; BALDWIN 1991e, 838). A költeményben főként az avarok ostromtechnikájáról és segédnépeiről találunk adatokat.

Theodóros Synkellos Herakleios császár uralkodása időszakában élt egyházi férfi volt, aki a bizánci követség tagjaként személyesen járt 623-ban az avar kagán főhadiszállásán. A szerző 627-ben írt és mondott el egy szentbeszédet, mely az avarok 626-os konstantinápolyi ostromáról emlékezik meg, Geórgios Pisidéshez hasonlóan ő is részletesen beszámol erről az eseményről (SZŐM 143; KAZHDAN 1991d, 2048; OSTROGORSKY 2003, 97). ${ }^{34}$ Munkájában pontos adatokat találunk az avarok fegyverzetére,

\footnotetext{
${ }^{32}$ Theophylaktos munkájának megírásakor föként Ioannes Epiphaneus történeti művét használta, de emellett feltételezhető, hogy Menandros Protéktór, Ailianos és szicíliai Diodoros munkái és valószínüleg a balkáni hadsereg egy tisztjének hadinaplója is forrásul szolgálhattak számára (SZÖM 140-141; OLAJOS 1979, 3-17; OLAJOS 1988, 14-66, 96-112; OLAJOS 2012, 30-47).

${ }^{33}$ Mérvadó szövegkiadása és fordítása Giorgo di Pisida. Poemi I. Panegiric Epici. Ed., Trans. Pertusi, A. Ettal 1959.

${ }^{34}$ Mérvadó szövegkiadása és francia fordítása Traduction et commentaire de l'homélie écrite probablement par Théodore le Syncelle sur le siège de Constantinople en 626. Ed., Trans. Makk, F. [Acta Universitatis Szegediensis de Attila József Nominatae. Acta Antiqua et Archaeologica 19. Opuscula Byzantina 3.] Szeged 1975.
} 
utánpótlás módjaira, katonai jeladásaira, ostromtechnikájára, valamint segédnépeire vonatkozólag.

A Chronicon Paschale címü mü ismeretlen nevü szerzője, Sergios pátriárka (610638) bizalmi embereként foglalkozott húsvét napjának kiszámolásával, ezért kapta munkája a Húsvéti krónika nevet. Munkája a világ teremtésétől a 629-es évig tárgyalja az eseményeket, azonban csak 627-ig maradt fenn (MORAVCSIK 1958, 241-242; SZŐM 142; BALDWIN 1991f, 447; OSTROGORSKY 2003, 97). ${ }^{35}$ A szerző művében részletesen kitér az avarok 626-os ostromára. Az avarok hadseregének létszámáról, elővédjéről, katonai jeladásairól, az ostromtechnikájukról és segédnépeikről találunk fontos információkat a forrásban.

A Miracula S. Demetrii első könyvét 610-620 táján Ioannés thessalonikei érsek készítette, aki átélte a város avar ostromát. A Szent Demeter csodáinak második könyvét egy ismeretlen szerző állította össze Thessalonikében a 7. század második felében. ${ }^{36} \mathrm{~A}$ mü mindkét része beszámol a Thessalonike (ma Thesszaloniké, Görögország) elleni avar, szláv támadásokról (SZÖM 141, 144; LEMERLE 1979, 9-42).

Feltehetően Euagriosnak az avarokat említő munkája Szent Pankratios (Szent Péter tanítványa) életét és vértanúságát örökítette meg. ${ }^{37}$ A képrombolás idején Szicíliába menekült egyházi férfi elbeszélésében saját korának viszonyait vetíti vissza a távoli múltba. Leírja, hogy a szicíliai görög csapatok Dyrrachium (Durazzo, Durrës, Albánia) és Athén környékén élő bálványimádó avarokat vittek el hadifogságba (OLAJOS 2001, 121122).

A hunok kapcsán már említett Paulus Diaconus és Tours-i Gergely történeti munkáiban az avarok korai történetére vonatkozó adatok is fellelhetők. Paulus Diaconus legjelentősebb alkotásában, a Historia Langobardorumban az avarokat illetően főként a langobard-avar kapcsolatokról szól (SZÖM 168-169; GALAMB 2012, 17-25). ${ }^{38}$ A történeti munkában néhány, az avarok fegyvereit említő rész mellett utalást találunk a folyón történő átkelés és az utánpótlás megoldásának módjaira, valamint az avar hadsereg segédnépeinek szerepére. Tours-i Gergely történeti munkájában egy helyen lelhető fel az

\footnotetext{
${ }^{35}$ Mérvadó szövegkiadása Chronicon Paschale. Ec. Dindorf, L. [Corpus Scriptorum Historiae Byzantinae] Bonnae 1832; angol nyelvü fordítása Chronicon Paschael 284-628 AD. Trans. Whitby, M.-Whitby, M. [Translated Texts for Historians 7.] Liverpool 1989.

${ }^{36}$ Mérvadó szövegkiadása és fordítása Les plus anciens recueils des miracles de Saint Démétrius. Le texte par Lemerle, P. Éditions du Centre national de la recherche scientifique. Paris 1979.

${ }^{37}$ Részleges szövegkiadása Iz istorii i povesti I. Ed. Veselovskij, A. N. [Sbornik Otdelenija Russkago Jazyka i Slovesnosti Imperatorskoj Akademii Nauk 40.2] Sanktpeterburg 1886, 65-128.

${ }^{38}$ Mérvadó szövegkiadása Pauli Historia Langobardorum I-III. Rec. Crivellucci, A. Roma 1918; magyar fordítása Paulus Diaconus. A langobardok története. Közreadja Galamb, Gy. [Mediaevalia] Budapest 2012.
} 
avarok hadászatára vonatkozó adat, mely a pszichológiai hadviselésükről szolgáltat számunkra információt (ADAMIK-MEZEI 2010, 292). ${ }^{39}$ Szintén az avarok korai történetére találunk adatokat a 6. századi költő, Corippus munkájában. Az afrikai származású szerző 567 körül írta a négy könyvből álló dicsőítő költeményét II. Iustinus megkoronázására (In laudem Iustini Augusti Minoris) (ANTES 1981, XI-CV; GRUBER 1986, 237). ${ }^{40}$ Munkájában csak néhány adatot találunk az avar hadsereg folyón történő átkelésére és az utánpótlás problémájára. A Fredegar neve alatt fennmaradt krónika valószínüleg három számunkra ismeretlen szerző átdolgozása eredményeként jött létre, mely kompiláció 660 táján nyerte el a végső formáját. A munka a világ teremtésétől 642-ig terjedő időszak történetét öleli fel (NONN 1989, 884; SZÁDECZKY-KARDOSS 1998, 171). ${ }^{41}$ Főként az avar hadsereg segédnépeire találunk benne utalást.

Az avarok fegyverzete és harcmodora szempontjából a latin nyelvü források csak gyér adatokat szolgáltatnak, jellemző rájuk, hogy rövid bejegyzésekben, az avarokat elfogultan, negatív színben mutatják be. Ezek közül Alcuin munkásságából a 796-ban íródott két levelét fontos kiemelni. ${ }^{42}$ A Brit-szigetekről származó teológus a frank-avar háborúról hitelesen tájékoztat (FOLKERTS 1980, 417-420; SZÁDECZKY-KARDOSS 1998, 260). Paulinus Aquileiensis aquileiai pátriárka tollából pedig egy költemény maradt fenn a 8. század végéből, mely Erich friauli gróf halálát mondja el (SZÁDECZKY-KARDOSS 1998, 301). ${ }^{43}$ Érdemes még megemlíteni a 9. századból az Epithapium Geroldit, Gerold gróf halálának a Sankt Gallen és Reichenau kolostorok halottas könyveiben található bejegyzését (SzÁDECZKY-KARDOSS 1998, 299) ${ }^{44}$ és Nagy Károly 805. évi dietenhofeni rendeletét (SZÁDECZKY-KARDOSS 1998, 93). ${ }^{45}$ A felsorolt latin nyelvű források csak egyegy, az avarok fegyverzetére vonatkozó adatokat tartalmaznak. Ezenkívül az avarok

\footnotetext{
${ }^{39}$ Szövegkiadására és fordítására vonatkozó adatokat lásd a fejezet hunokra vonatkozó írott forrásokkal foglalkozó alfejezetében.

${ }^{40}$ Mérvadó szövegkiadása és francia fordítása Corippe. Flavius Cresconius Corippus: Éloge sw l'empereur Justin II. Texte établi et traduit par Antes, S. [Collection "Budé"] Paris 1981.

${ }^{41}$ Mérvadó szövegkiadása Chronicarum quae dicuntur Fredegarii Scholastici libri IV. cum continuationibus. Ed. Krusch, B. In: Monumenta Germaniae Historica. Scriptores rerum Merovingicarum II. Hannoverae $1888,1-193$.

${ }^{42}$ Mérvadó kiadása Monumenta Germaniae Historiae. Epistolae IV. Epistolae Carolini aevi II. Ed. Dümmler, E. Berolini 1895, 18-481.

${ }^{43}$ Mérvadó kiadása Monumenta Germaniae Historica. Scriptores rerum Germanicarum in usum scholarum ex Monumentis Germaniae Historicis separatim editi. Poetae Latini medii aevi I. [Poetae Latini Carolini I.] Red. Duemmler, E. Berolini 1881, 131-133.

${ }^{44}$ Mérvadó kiadása Monumenta Germaniae Historica. Scriptores rerum Germanicarum in usum scholarum ex Monumentis Germaniae Historicis separatim editi, Poetae Latini medii aevi I. [Poetae Latini aevi Carolini I.] Ed. Duemmler, E. Berolini 1881, 114.

${ }^{45}$ Mérvadó kiadása Monumenta Germaniae Historica. Scriptores rerum Germanicarum in usum scholarum ex Monumentis Germaniae Historicis separatim editi, Legum sectio II. 1. (Capitularia regum Francorum I.) Ed. Boretius, A., Hannoverae 1883, 123.
} 
harcmodora kapcsán még a frank évkönyveket (Annales regni Francorum, Annales qui dicuntur Einhardi, ${ }^{46}$ Annales Laureshamenses ${ }^{47}$ ) érdemes megemlíteni (SZÁDECZKYKARDOSS 1998, 279-280), az ezekből nyerhető információkból esetleg az avarok egy taktikai elemére, a felperzselt föld taktikájára következtethetünk.

A kései keletkezésü görög nyelvü források közül nyolc auktor müvét érdemes vizsgálni az avarok harcmodora és fegyverzete okán. Azonban hangsúlyozandó, hogy ezek a művek eléggé csekély forrásértékkel bírnak témánkra vonatkozólag. Többnyire a fent nevezett szerzők alkotásait kivonatolják az avarokkal kapcsolatban.

Theophanes Homologétés szerzetes a 9. század elején írta meg Cronographia címü világkrónikáját, ${ }^{48}$ mely a 284 és 813 közötti időszakot öleli fel. Fontos jellemzője munkájának a gondosan kidolgozott kronológiai rendszer. Bár a mélyebb tudományosság, oknyomozás, objektivitás hiányzik a krónikájából, ennek ellenére rendkívüli jelentősséggel bír történeti mủve a 7-8. század eseményeire vonatkozólag, ugyanis Theophanes olyan történeti munkákat használt fel, amelyek mára már elvesztek (MORAVCSIK 1958, 531-537; SZÖM 145; OSTROGORSKY 2003, 97). Azonban az avarok harcmodora, fegyverzete kapcsán kevés jelentőséggel bír. Nikephoros Patriarcha szintén a 9. század első felében írta meg a Rövid történelem (Breviárium) címü munkáját, mely a 602 és 769 közötti időszak történetét dolgozza fel. Theophaneshez hasonlóan Nikephoros is olyan müveket használt fel, melyek mára már elvesztek (MORAVCSIK 1958, 456-459; CUTLER 1991, 1477). ${ }^{49} \mathrm{Az}$ avarok harcmodorára csak néhány utalást találunk a bizánci patriarcha müvében, főként az avar hadsereg segédnépeire vonatkozólag. Kónstantinos Porphyrogennétos császár fiának, a későbbi II. Romanosnak szánt De administrando imperio címü diplomáciai kézikönyvében (SZÖM 152; MORAVCSIK 2003, 15-42) ${ }^{50}$ csak néhány utalást találunk az avar hadsereg harcmodorára vonatkozóan. Zonaras, a 12. század első felében élt történész, egyházjogász, teológus Epitomé historión című világkrónikájának avarokra vonatkozó

\footnotetext{
${ }^{46}$ Mérvadó kiadásaik Monumenta Germaniae Historica. Scriptores rerum Germanicarum in usum scholarum edidit 6. Post ed. Pertzii, G. H. Rec. Kurze, F. Hannoverae 1985.

${ }^{47}$ Mérvadó kiadása Monumenta Germaniae Historica. Scriptorum 1. Annales et chronica aevi Carolini. Ed. Pertz, G. H. Hannoverae 1826, 22-39.

${ }_{48}$ Mérvadó kiadása Theophanis Chronographia. Rec. Boor, C. Lipsiae 1883-1885; angol fordítása The Chronicle of Theophanes Confessor. Byzantine and Near Eastern History AD 284-813. Trans. Mango, C. Scott, R. Oxford 1997.

${ }^{49}$ Mérvadó szövegkiadása Nicephori archiepiscopi Constantinopolitani opuscula historica. Ed. Boor, C. Lipsiae 1880; angol nyelvü fordítással Nikephoros Patriarch of Constantinople. Short History. Ed. Mango, C. - Scott, R. Oxford 1997.

${ }^{50}$ Mérvadó szövegkiadása és angol nyelvủ fordítása Constantine Porphyrogenitus De administrando imperio. Ed. Moravcsik, Gy. [Corpus Fontium Historiae Byzantium 1.] Dumbarton Oaks $1985 ;^{2}$ görögmagyar nyelvü bilingvis kiadása Bíborbanszületett Konstantín. A birodalom kormányzása. Ford. Moravcsik Gy. Budapest 2003. ${ }^{2}$
} 
részéhez Theophanes és Theophylaktos Simokattés müveit használta fel (SZÖM 159; KAZHDAN 1991e, 2229). ${ }^{51}$ Konstantinos Manasses (1130 k.-1187 k.) legjelentősebb műve a Synopsis Historiké, melyben verses formában a világtörténetet 1081-ig mutatja be. ${ }^{52}$ Naupaktosnak a 12. században élt metropolitája krónikájában az avarokat, kazárokat és a szedzsukokat említi meg. Munkája feltűnő egyezést mutat Zonaras müvével (MORAVCSIK 1958, 353-354; KAZHDAN 1991f, 1280). Plótinos Thessalonikeus alkotásának datálása eléggé bizonytalan, körülbelül a 9 és a 10. század közé lehet tenni. A thessalonikei érsek munkájának megírásához felhasználta a Miracula S. Demetriit (SzÁDECZKY-KARDOSS 1998, 112; LEMERLE 1981, 29-31). ${ }^{53}$ A 14. század első felében élt egyházi író, Nikephoros Kallistos Xanthopulos tizennyolc könyvből álló egyháztörténeti munkája maradt ránk, melyben az avarokra vonatkozó részek megírásához felhasználta Theophylaktos Simokattés müvét (SZÖM 157; TALBOT 1991, 2207). ${ }^{54}$ Konstantinos Akropolités hagiografikus müvei között ránk maradt egy beszéde a 14. század első feléből Szent Demetrios csodatetteiről, amelyben az avarokat is megemlíti (MORAVCSIK 1958, 353). Ezek a munkák csak néhány adatot tartalmaznak az avarok fegyverzetéröl és esetleg harcmodoráról, forrásértékük azonban nagyon csekély.

\footnotetext{
${ }^{51}$ Mérvadó kiadása Ioannis Zonarae epitomae historiarum libri 13-18. Ed. Büttner-Wobst, T. Bonnae 1897; német fordítása Johannes Zonaras. Militäre und Höflinge im Ringen um das Kaisertum. Übers. Trapp, E. Graz-Wien-Köln 1986.

${ }_{52}$ Mérvadó kiadása Constantini Manassis breviarium historiae metricum. Rec. Bekkerus Bonnae 1837; fordítása Die slavische Manasses-Chronik. Übers. Bogdan, J. [Slavische Propyläen 12.] München 1966.

${ }^{53}$ Mérvadó kiadása Theophilos Joannou, Mnemeia hagiologica nyn proton ekdidomena. Ed. Dummer, J. Leipzig 1973, 40-53.

${ }^{54}$ Mérvadó kiadása Nicephori Callisti Xantohopuli Ecclesiasticae historiae libri 18. In: Patrologiae cursus completus, Series graeca 147. Rec. Migne, J.-P. Paris 1865.
} 


\section{A hunok fegyverzete és harcmodora}

A 370-es években a Volgánál megjelenő hunok elsőként a kelet-európai népeket győzték le, melyek vagy betagozódtak a hun seregbe (például az alánok és az osztrogótok), vagy pedig nyugat felé menekültek (például vandálok). A hunok föképpen az 5. század elejétől támadták a Keletrómai Birodalmat, ezzel egyidejűleg viszont az 5. század közepéig a Nyugatrómai Birodalommal szövetségi viszonyban álltak, és a rómaiakkal szövetségben több népet (vízigótok, burgundok) győztek le Nyugat-Európában. Ez a helyzet az 5. század közepén változott meg, amikor is Attila 451-ben egy jelentős hadjáratot vezetett Gallia, majd ezt követően Észak-Itália ellen. 453 után azonban Attila halálával széthullott a Hun Birodalom, a nedaói csatát követően a hunok keletre menekültek, ahol rövid időn belül beolvadtak a szomszédos népekbe. ${ }^{55}$

\section{1. Fegyverzet}

Tizenhat forrásban található olyan információ, melyből a hunok fegyverzetére következtethetünk. A latin nyelvü források közül Pacatus, Sidonius Appolinaris, Merobaudes, Szent Jeromos, Ammianus Marcellinus, Iordanes, Tours-i Gergely említi egyértelmüen a hunok fegyverzetét. A görög nyelvü források közül Olympiodoros, Priskos, Sozomenos, Asterios müveiben és a Suda lexikonban találhatók e nomád nép fegyvereire vonatkozó információk. Ezenkívül még egy skandináv sagában (Hervarar saga ok Heiðreks) és három szír szerző (Pseudo-Kallisthenes, Pseudo-Ephraem, Josue Stylita) munkájában találhatók információk a hunok fegyverzetére vonatkozóan. A Waltharius hősi eposzban pedig közvetett utalást találunk a hunok vágófegyverzetének viselési módjára.

Az írott forrásokban a támadófegyverek közül a távolsági fegyvereken belül íjra és nyílra vannak adataink. A közelharci fegyverek közül pedig a kard, a sax és a pányva lelhető fel a forrásokban. A lándzsák használatára viszont csak közvetve tudunk következtetni a kútfők leírásaiból. Emellett a védőfegyverzetre is (páncél, sisak, pajzs) vannak biztos adataink. Azonban az ütő- és sújtófegyverekre és a lovak vértezetére vonatkozólag semmilyen adatot nem találunk ezekben a forrásokban, használatukat a régészeti források sem támasztják alá (ZASZECKAJA 1994, 23-39).

\footnotetext{
${ }^{55}$ A hunok történetére lásd például THOMPSON 2003; MAENCHEN-HELFEN 1997; WIRTH 1999.
} 


\section{1. 1. Íj}

A hunok íját négy latin és görög forrás említi, melyek kétféle terminust használnak ezekre

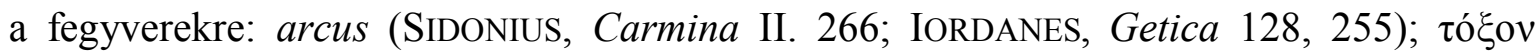
(Olympiodoros 19). ${ }^{56}$ Valamint két szír szerző említi a hunok íját (Pseudo-Kallisthenes 265, Pseudo-Ephraem (189) 6. vö. KMOSKÓ 2004, 77, 84).

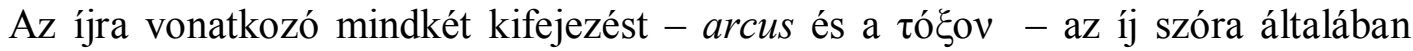
használták a korabeli szerzők, de ebben az időben elsősorban összetett reflexíjat jelentett (Kolias 1988, 214-215; GLARE 2000, 164). Sidonius a hunok íjai kapcsán kiemelte, hogy ezek a fegyverek szép mívüek voltak (SIDONIUS, Carmina II. 266).

Az írott forrásokban található kifejezésekből kikövetkeztethető ijtípust a régészeti adatok is alátámasztják, miszerint a hunoknak a végein és markolatán csontlemezekkel megerősített, aszimmetrikus összetett reflexíjuk volt (BÓNA 1993a, 161-164; TOMKA 1993b, 17; ZASZECKAJA 1994, 35-36). ${ }^{57}$ A források többsége kiemeli az íj fontosságát a hun harcmodorban (például IORDANES, Getica 128; AMMIANUS MARCELLINUS XXXI. 2, 9; OlympiOdoros 19; SIDONIUS, Carmina II. 266), ennek a távolsági fegyvernek a gyakorlati szerepével párhuzamosan szimbolikus jelentősége is fontos volt, a hunok kultusztárgyaként és uralkodói szimbólumaként is szolgált. Erre utal Iordanes munkájának egyik részlete, melyben Attila halálát Marcianus keletrómai császár (450-457) álmában a hun uralkodó törött íja jelképezte (IORDANES, Getica 255. vö. Kiss 2005, 93). Ebből a történetből feltételezhető, hogy az íj ténylegesen Attila hatalmának a szimbóluma volt, vagyis az ö uralkodói jelvénye lehetett (HARMATTA 1951, 180). Iordanes ezen adatára párhuzamként hozhatók fel a régészeti anyagban megtalálható, aranylemez borítású íjak. Ezek nem csontlemezzel megerősített reflexíjak voltak, hanem aranylemezzel díszített egyszerü faíjak, amelyeknek pusztán csak reprezentációs szerepük volt, fegyverként nem lehetett őket használni. Ezek vagy a gyakorlatban használt íjakhoz hasonló méretủek, vagy kisebbek voltak, és vagy egész felületüket, vagy csak egy részüket (a két végét és a markolatot vagy csak az egyik végét) borították be aranylemezzel (BÓNA 1993b, 24; TOMKA 1993b, 17; BÓNA 1993a, 169-170; ANKE 1998, 62-65). Bodo Anke 1998-ban térképre vitte a hun kori aranyíjak lelőhelyeit. ${ }^{58}$ Mivel viszonylag nagy számban kerültek

\footnotetext{
${ }^{56}$ Ezenkívül még Zosimos a $\kappa \alpha \tau \alpha \tau o \xi \varepsilon v ́ \omega ~ ' l e n y i l a z '$ igével utal a hunok íjára (ZosiMOs IV. 20).

57 Például Pokrovszk 17., 18. kurgán, Kizil-Adir (ZASZECKAJA 1994, 35), Aktobe II., Kzil-Kajnar-Tobe, Wien-Simmering (ANKE 1998, 56-58).

58 Jakuszowice, Pécs-Üszög (LÁSzló 1951, 107-118), Bátaszék, Szeged-Nagyszéksós, Kercs-Gliniscse, Kubej, Borovoje/Scsucsevo, Novogrigorjevka, Novoivanovka, Vlagyimirszk (ANKE 1998, 205).
} 
elő, és elterjedésük nagy területen figyelhető meg (ANKE 1998, 62-65, 205, 215), így Göckenjan arra a következtetésre jutott, hogy aranyíja nemcsak Attilának lehetett, hanem Attila helytartói, a csatlakozott és alávetett népek vezetői is viselhették ezeket a fegyvereket, melyek az uralkodót, a központi hatalmat szimbolizálhatták a birodalom peremterületein (GÖCKENJAN 2005, 67). Az aranyíj mint uralkodói szimbólum megfigyelhető az eurázsiai steppén más nomád népeknél is, ${ }^{59}$ a legyőzhetetlen napot, valamint az ég feletti uralmat szimbolizálhatta. Erre vonatkozóan a hunok esetében nem találunk közvetlen adatot az írott forrásokban. ${ }^{60}$ Viszont ha Priskos néhány híradását, ${ }^{61}$ melyben Attila személyét összekapcsolja a nappal, összevetjük Marcianus császár Iordanes munkájában található álmával, valamint a hun régészeti anyagban található aranyíjakkal, akkor a hunok esetében is feltételezhető, hogy az aranyíj szimbolizálhatta a napot és egyben az uralkodót is (GÖCKENJAN 2005, 67-69).

\section{1. 2. Nyíl}

Az íjhasználat mellet több forrás említi a hunok nyilát is, négyféle elnevezéssel: sagitta (HieronyMus LX. 17; IORDANES, Getica 128; 213, 249; 261); telum (MEROBAUdeS 8081; Ammianus Marcellinus XXXI. 2, 9), spiculum (SidoniUs, Carmina II. 266; Ammianus Marcellinus XXXI. 2, 9); iaculum (SidOnIUS, Carmina II. 267). Valamint két szír szerző munkájában figyelhető meg a hunok nyila (Pseudo-Kallisthenes 265, Pseudo-Ephraem (189) 6. vö. KMOSKÓ 2004, 77, 84). A hunok nyíltegezére egy forrásban találunk adatot: pharetra (MEROBAUDES 80-81).

A sagitta terminus nem jelöl konkrét típust, általában a nyílra utal (KOLIAS 1988, 218; GLARE 2000, 1679), lehetett köpüs és nyéltüskés, három-, négyélü, levél alakú, stb. (FIEBIGER 1920, 1741-1746). ${ }^{62}$

\footnotetext{
${ }^{59}$ Például a szkítáknál és a szeldzsukoknál az íj uralkodói szimbólum volt (HÉRODOTOS IV. 10. vö. Muraközi 2000, 268-269; KAFESOĞLU 1988, 86).

${ }^{60}$ Érdemes megjegyezni ezzel kapcsolatban, hogy Asterios szerint a hunok fegyverzete fényüző és díszes volt (ASTERIOS 9), ami utalhat esetleg egyes íjak aranydíszítésére is.

${ }^{61}$ Priskos töredékében található, hogy az akatzirok királya, Kuridachos Attilát a naphoz hasonlítja, Kuridachos azzal az érvvel utasította vissza a meghívást Attila udvarába, hogy ha a napba nem tud nézni, akkor hogy lenne lehetséges Attila szemébe nézni (PrISKOs 11. 2, 255-256. vö. Blockley 1983, 259). Göckenjan szerint ehhez a jelenséghez kapcsolható az is, hogy Attila legidösebb fia apja jelenlétében tiszteletböl lesütötte a szemét (PRISKOS 13. 38-40. vö. Blockley 1983, 285; GöCKENJAN 2005, 67). Schäfer Tibor ellenben úgy véli az akatzir király története kapcsán, hogy Kuridachos távolmaradásának nem szakrális, hanem politikai okai voltak (SCHÄFER 2001, 24).

${ }^{62}$ A Szent Jeromosnál található terminus esetében kiemelendő, hogy az egyháztanító munkájában a hunok által használt sagitta-t szembe állította a rómaiak által használt lándzsákkal. Ezzel mintegy a két népről
} 
A telumot elsősorban távolharcban használatos fegyverekre alkalmazták, vonatkozhatott nyílra és dobódárdára is (FINÁLY 1884, 1960; GLARE 2000, 1911). Merobaudes a nyilakat összefogó tegez megfogalmazással azonban egyértelmüvé teszi a szó nyíl jelentését (Merobaudes 80-81). ${ }^{63}$ Ammianus Marcellinus munkájából is kitünik, hogy a szerző a távolról kilőtt nyilakra gondolhatott. Ammianus ugyanebben a mondatban ugyanarra a fegyverre utalva a nyílra alkalmazza a spiculum kifejezést is. ${ }^{64}$

A spiculum elsősorban a pilumhoz hasonlóan 'dobódárda' jelentésben fordul elő a forrásokban (KOLIAS 1988, 186; COULSTON 2002, 13), ${ }^{65}$ de emellett 'nyíl' jelentésben is használatos volt (FINÁLY 1884, 1858; GLARE 2000, 1804). Sidoniusnál egyértelmüen eldönthető, hogy a szerző a nyílvesszőre gondolt, ugyanis az íjjal együtt szerepel ez a terminus (,,arcus et spicula”). A iaculumot is föként dobódárdára alkalmazták a korabeli szerzők, de általános lövedék jelentése is ismert (GLARE 2000, 815). Sidoniusnál ez esetben nyílra vonatkozik a kérdéses terminus, ugyanis a fent nevezett spiculum kifejezés helyett és arra visszautalva használja a szerző egy sorral lejjebb. A szerző hangsúlyozza, hogy a hunok íjai és a nyilai szép mívűek, majd a következő mondatban ezeknek a lövedéknek a veszélyességét emeli ki (SIDONIUS, Carmina II. 266-267).

A pharetra kifejezésből nem lehet következtetni a nyíltartó szerkezetére, általánosan használták a tegezekre ezt a kifejezést (FINALY 1884, 1485; GLARE 2000, 1372). Merobaudes emellett megemlíti, hogy ezek a tegezek aranyozottak voltak (auratae pharetrae) (MEROBAUDES 80-81). Nem kizárt, hogy erre a jelenségre is vonatkozhat a 4. század második felében élt Asterios Amasea püspökének a híradása is, mely szerint a hun fegyverzet pompás és fényüző (ASTERIOS 9). A hunokhoz köthető régészeti anyag egy jellegzetes leletcsoportja a pikkely- vagy hálómintás, poncolt arany-, aranyozott bronzvagy ezüstlemezek, melyek esetében felmerült az a lehetőség, hogy nyíltartó tegezről is származhattak (ALFÖLDI 1932, 26; TOMKA 1993b, 17-18; BÓNA 1993a, 169, 173-174). ${ }^{66}$

alkotott sztereotípiával akarta a szerző a közöttük lévő különbséget hangsúlyozni (HIERONYMUS 60, 17). Így a hunok fegyverzetére nagyon kevés információt szolgáltat számunkra.

63 ,circumdent tela pharetrae” (MEROBAUDES 80-81).

64 „...quod procul missilibus telis acutis ossibus pro spiculorum acumine arte mira coagmentatis et distinctis...” (AMMIANUS MARCELLINUS XXXI 2, 9). Bár a spiculumot legtöbbször a 'dobódárda' jelentésben használták az auktorok (KoLIAS 1988, 186), de emellett nyílra vonatkozóan is megtalálható a forrásokban (GYÖRKÖSY-KAPITÁNFFY-TEGYEY 1990, 521; GLARE 2000, 1804). Ebben az esetben azonban a 'nyíl' jelentés a mérvadó.

${ }^{65}$ A „,nehéz” dárdák hosszú vasnyéllel rendelkeztek, és kisméretü, gúla alakú hegyük volt. Ezek képesek voltak átütni a páncélokat és a pajzsokat is (COULSTON 2002, 13).

${ }^{66}$ Feltételezhető, hogy a Novogrigorevka 8. kurgán, Szeged-Nagyszéksós és Pécs-Üszög lelőhelyeken talált aranylemez töredékek egy része tegezborítás lehetett (ALFöLDI 1932, 26; BóNA et al. 1993, 17-18; BÓNA 1993, 169, 173-174). 
Ezeknek a díszes nyíltegezeknek szintén lehetett szimbolikus jelentésük. ${ }^{67}$ A nyílkötegek és a tegezek a törzsek szövetségét, egységét jelképezhették a nomád népeknél. Ezzel párhuzamosan a tegez elvétele az alávetést jelképezhette. A hun uralkodó kíséretéhez tartozó legfontosabb személyek viselhették betöltött pozíciójuk legitimizációs jelképeként (GÖCKENJAN 2005, 72-73). ${ }^{68}$

A hunok nyílhegyének anyagára vonatkozó adatot csak Ammianus Marcellinus történeti munkájában találunk, miszerint a hunok nyílhegyei éles csontból készültek (AMmianUs MARCELlinUs XXXI 2,9). Tekintetbe véve, hogy a szerzö értesülései kétségesek, és a forrás tele van toposzokkal, ez az információ nem tekinthető hitelesnek a hunok fegyverzetére vonatkozólag. Régészeti adatok sem támasztják alá ezt a híradást, ${ }^{69} \mathrm{a}$ hunokhoz köthető leletanyagban vasból készült, nyéltüskés, többnyire három élü nyílhegyek kerültek elő (TOMKA 1993b, 17; BÓNA 1993a, 163-164; ZASZECKAJA 1994, $36-39) .^{70}$

\section{1. 3. Vágófegyver}

A hunok vágófegyveréről hét szerző emlékezik meg: ensis (MEROBAUDES 84); ferrum (AMmianus MARCELlinus XXXI. 2, 10); gladius (IORDANES, Getica 183; GREGORIUS TURONENSIS II, 6); mucro (AMMIANUS MARCELlinUs XXXI. 2, 10; HiERONYMUS LX, 17);

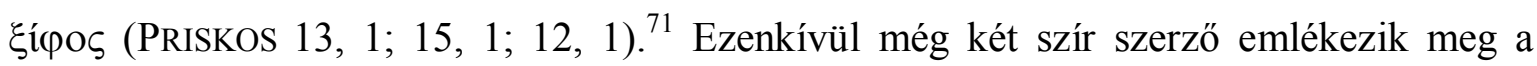

\footnotetext{
${ }^{67}$ A Mongolok titkos történetében több utalást találunk erre a fegyverre vonatkozóan, melyekből kiderül, hogy a tegez a férfierő és a méltóság jelképe volt a mongoloknál: ha valakinek a tegezét elvették, az azt jelentette, hogy lefegyverezték és alávetették (SHM 124, 187, 219, 224, 225. vö. Rachewiltz 2006, 50, 108, 150,152-155). A tegez jelentőségére utal továbbá a nomád népek körében a Kubiláj parancsára összeállított kormányzási kézikönyvben található adat, mely szerint a Mongol Birodalom kilenc jelvénye között található az aranytegez is. Hatalmi jelvény volt még ezenkívül a Mongol Birodalomban a fekete zászló, a vörös kürt, a zászlóval ellátott nagy sátor, a sárga dob, a gyémántos szablya, az aranynyereg, az öv is (SAGASTER 1976, 295-299).

${ }^{68}$ Az azonban hangsúlyozandó, hogy az íj volt a legjelentősebb az uralkodói szimbolikában. A nyíl és a nyíltegez alsóbbrendủ volt az íjnál (GÖCKENJAN 2005, 73).

${ }^{69}$ Nikonorov, bár ö sem tartja hitelesnek Ammianus ezen híradását, úgy véli, hogy a hunok a délorosz steppei megjelenésükkor rövid ideig használhattak csontból készült nyílhegyeket is (NIKONOROV 2010a, 267). BelsöÁzsiai hiung-nu területeken a csontnyílhegyek használata elterjedt volt a három élủ vas nyílhegyek mellett (NIKONOROV-HUDJAKOV 2004, 59-60). Nikonorov úgy véli, hogy az európai hunok Belső-Ázsiából hozhatták magukkal ezt a fegyvertípust, amely használatával rövid időn belül felhagytak, és a vas nyílhegyet részesítették előnyben (NIKONOROV 2010a, 267).

${ }^{70}$ Például Kiyzil-Adir, Novogrigorjevka 8. kurgán, Pokrovszk 17. kurgán, Rovnoje, Wien-Simmering, PécsÜszög (BÓNA 1993, 164; ZASZECKAJA 1994, 36-39).

${ }^{71}$ Nikonorov a hunok kardjait említő források között utal Malalas munkájára is (NIKONOROv 2010a, 267). Malalas szerint Attila halálának okaként ismert egy olyan nézet is, miszerint Aetius bérelte fel Attila egyik

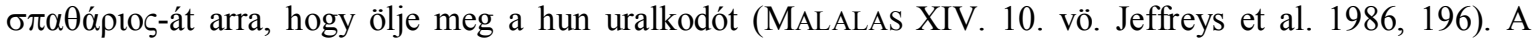
forrásban található $\sigma \pi \alpha \theta \alpha$ óı (MALALAS XIV. 10) kifejezés szószerinti fordítása 'kardhordozó' jelentésủ. A spatharius terminus az 5-6. században testőrökre vonatkozott, akik lehettek magánemberek és a császár
} 
hunok kardjáról (Pseudo-Kallisthenes 264, 265, Pseudo-Ephraem (189) 6. vö. KMOSKó $2004,77,84-85)$.

Az ensis kifejezést többnyire általánosan a kardra használták (FINALY 1884, 693; GLARE 2000, 609). ${ }^{72}$ Emellett azonban megfigyelhető egy konkrétabb használata is, vagyis hosszú, széles, kétélü kardként is megjelenik a forrásokban (WALTHARIUS 336).

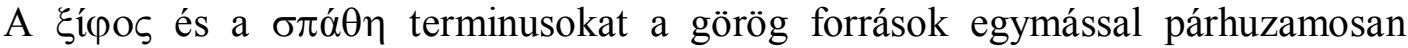
használták, és mindkettő általában hosszú vágófegyvert jelentett, és elsősorban lovassági fegyverek voltak. Ezek hosszú $(70-100 \mathrm{~cm})$, széles, egy- vagy kétélű pengékkel rendelkeztek (KOLIAS 1988, 136).

A gladius kifejezés elsősorban rövid $(40-70 \mathrm{~cm})$, keresztvas nélküli, vágásra és szúrásra egyaránt használatos vágófegyvert jelentett (KOLIAS 1988, 136). A Iordanesnél található terminus semmilyen hitelességgel nem bír a hunok kardjára vonatkozólag, ugyanis ezt a részletet közvetve Priskos munkájából vette át, és a görög szerző fennmaradt

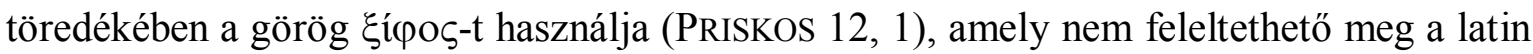
gladiusnak. A Tours-i Gergely munkájában található kifejezés sem használható a hunok fegyvertípusára, ugyanis egyszerüen „töltelékszóként” használja a gladius terminust: a hunok karddal pusztítottak el bizonyos területeket. (GREGORIUS TURONENSIS II, 6).

A mucro kifejezést a korabeli szerzők kardra és tőrre egyaránt használták, tehát konkrét típusra pusztán ebböl nem lehet következtetni (FINALY 1884, 1266; GLARE 2000, 1139-1140). ${ }^{73}$ A ferrum terminusnak nem volt konkrét jelentése, a fegyver szóra általában vonatkozott. Ezen belül jelenthetett kardot, dárdát, tőrt (FINÁLY 1884, 788; GLARE 2000, 691). ${ }^{74}$ Ammianus Marcellinusnál mindkét kifejezés, a mucro és a ferrum is megtalálható, és a forrásból kiderül, hogy a két terminus alatt ugyanarra a fegyverre gondolhatott (AMMIANUS MARCELLINUS XXXI. 2, 10). Így a ferrum kifejezés ez esetben a kardra vagy törre vonatkozik.

védelmezői is. A Bizánci Birodalomban a spathariusok fontos pozíciót töltöttek be a császári udvarban. A 8 . század elejére ez a funkció úgy tünik, hogy tiszteletbeli méltósággá vált (BRÉHIER 2003, 97, 132; KAZHDAN 1991a, 1935-1936). Tehát ez a kései forrás elsősorban Attila testőrségére utal, és nem a hunok kardhasználatára.

${ }^{72}$ Quintilianus, a Kr. u. 1. században élt szónok úgy véli, hogy a gladiusnak és az ensisnek ugyanaz a jelentése, teljesen mindegy, hogy melyiket használjuk (QuINTILIANUS X. 1, 11). A római szónok esetében azonban hangsúlyozni kell, hogy bár müvelt volt, a hadi tudományokhoz kevésbé értett, így a fegyverterminusok értékelése kapcsán nem tekinthető mérvadónak a véleménye.

${ }^{73}$ Szent Jeromos leveleinek magyar fordításában a mucro kifejezés szablyaként szerepel (HIERONYMUS 60, 17. vö. Adamik-Puskely-Takács 2005, 268), ez az interpretáció azonban nem fogadható el a hunok esetében, ugyanis csak az avaroknál figyelhető meg először a szablyahasználat Kelet-Európában.

${ }^{74}$ Quintilianus szerint elsősorban kardot jelentett ez a szó (QUINTILIANUs X. 1, 11). 
A forrásokból tehát a hosszú, kétélü kardtípus ( $\xi i ́ \varphi o \varsigma, \sigma \pi \alpha ́ \theta \eta)$ egyértelmüen elkülöníthető, és emellett valószínűsíthető a rövid egyélü kardok jelenléte is. Erre utalhat a Waltharius hősi eposz egy részlete is. A forrás szerint Waltharius kétféle kardot csatolt fel az övére: bal oldalra egy kétélü kardot (ensis), és a jobb oldalra pedig egy egyélüt pannoniai mintára (WALTHARIUS 336-338). Az eposz a 9. vagy a 10. században keletkezett, valószínüleg egy szent galleni barát jegyezte fel, a történet egy germán hösmondán alapul, és az Attila hun uralkodó udvarába került három túsz történetét örökíti meg (VOLLMANN 1991, 1171-1187; VOGT-SPIRA 1994, 5-20; MAKKAY 1999, 109-165). ${ }^{75}$ Helmut Nickel, majd Nickel nyomán Nikonorov a hunok kardviseletének rekonstruálása kapcsán használta a forrásrészletet. Nickel véleménye szerint a forrásban található vágófegyverek a hosszú, kétélü karddal, a spathával és a rövid egyélüvel, a semispathával azonosíthatók. Munkáikból kitünik a kardviselettel kapcsolatban az is, hogy ezeket a fegyvereket együttesen viselték az övükön, jobb oldalra a rövidebbet, bal oldalra pedig a hosszabb kardot függeszttették fel (NICKEL 1973, 138; NiKONOROV 2002, 285-286; NiKONOROV 2010a, 267-268). A forrásban található információkat a régészeti adatok is alátámasztják, a hunok esetében a régészeti anyagban kétféle kardtípus figyelhető meg: egy hosszú $(\mathrm{kb} .90 \mathrm{~cm})$ kétélü kard ${ }^{76}$ és egy rövidebb $(40-60 \mathrm{~cm})$ egyélü harci kés/tőr. ${ }^{77} \mathrm{~A}$ forrásban szereplő keskeny, hosszú saxok a korai népvándorlás korban, főként a 4. század végén, 5. század elején jelentek meg Kelet- és Közép-Európában, és használatuk a germán népek körében is elterjedt. A sírokban főként a hosszú, kétélü karddal együtt kombinálva figyelhetők meg. ${ }^{78}$ Míg a délorosz steppén lovassági fegyverként funkcionált a sax, addig a germánoknál föként gyalogsági fegyver volt, és a spathával kombinálva használták (WERNER 1956, 38-46; ZASZECKAJA 1994, 23-35; ANKE 1998, 93-99). Tehát a Waltharius hősi eposz információja, miszerint pannoniai mintára visel egyélü fegyvert, egyértelmüen összefüggésbe hozható a 4. század végén, 5. század elején Kelet-Közép-Európában megjelenő és a germán népek körében is elterjedő saxokkal.

Rátérve a vágófegyverek díszítésére, Merobaudes 5. századi költő leírja, hogy több más eszközzel együtt a hun kardok is aranyozottak voltak, és valószínúleg a

\footnotetext{
${ }^{75}$ A forrásban a hun népnév mellett az avar is feltűnik, mint egymás szinonimái. A hunok mellett felmerült a kutatásban, hogy esetleg az avarok vagy a honfoglaló magyarok fegyverviseletére vonatkozhat-e a fent nevezett részlet (VOGT-SPIRA 1994, 5-20; MAKKAY 1999, 109-165). Dienes István felvetette, hogy a forrásrészlet a honfoglaló magyarok fegyverzetére utal, és a szablya lehet ez a jobb oldalra felkötött egyélü fegyver (DiENES 1969, 120). Ezzel kapcsolatban azonban hangsúlyozandó, hogy a honfoglaló magyarok - a forrás híradásával ellentétben - a szablyát a bal oldalon viselték (MAKKAY 1999, 104; KovÁCS 2003, 294).

${ }^{76}$ Például Jakuszowice, Lengyeltóti, Szirmabesenyő, Pokrovszk-Voszhod (ANKE 1998, 205-206).

${ }^{77}$ Zevakino, Kzil-Kajnar-Tobe, Csongrád-Kenderföldek, Érmihályfalva (ANKE 1998, 207).

${ }^{78}$ Szirmabesenyő, Érmihályfalva, Wien XXI-Leopoldau 3. sír, Esslingen-Rüdern (ANKE 1998, 96-99).
} 
forrásrészletben található, drágakővel történő berakások kifejezés is a kard díszítésére vonatkozik a forrásban (MEROBAUDES 84). ${ }^{79}$ Priskos fennmaradt töredékében is olvasható, hogy a hunok kardjaikat arannyal és drágakövekkel díszítették (PRISKOS 13, 1). Hasonló véleményen van Asterios is, aki költeményében kiemeli a hun fegyverzet pompás, fényüző voltát (Asterios 9). A régészeti leletek abszolút alátámasztják Merobaudes, Priskos és Asterios híradását. Hasonlóan az íjhoz, a kard is hatalmi szimbólum, méltóságjelvény lehetett a hunok körében, jelzi ezt a régészeti anyagban megfigyelhető díszkardok csoportja: rekeszes díszítésü keresztvasa, kardhüvelyük aranylemezes borítása, rekeszes kőberakása, kardgombjai, ${ }^{80}$ esetleg a markolatuk aranyborítása (TOMKA 1993b, 18; BÓNA 1993a, 165-166; 243-259; ZASZECKAJA 1994, 23-34). Ugyanúgy, mint az íjnak, a kardnak is szakrális szerepe lehetett a hunok körében, az ij mellett a kard is az uralkodói hatalom egyik legelőkelőbb szimbólumának számított, amely legitimizálta viselőjének a hatalmát, és biztosította az uralma kontinuitását (GÖCKENJAN 2005, 66). ${ }^{81}$ Priskos fennmaradt töredékében és a Priskost felhasználó Iordanes történeti munkájában megőrződött Attila kardjának mitikus története, miszerint egy pásztor talált rá a földbe ásott Mars/Árész kardjára, és elvitte a hun uralkodónak. Attila nagyon megörvendett a kardnak, mert úgy vélte, hogy ez a fegyver az egész világ urává teszi őt, és az összes hadjáratában biztosítja számára a győzelmet Mars/Árész kardja (IORDANES, Getica 183; PRISKOS 12, 1). A kard szakrális szerepe nem ismeretlen más eurázsai steppei nomád népek körében sem. ${ }^{82}$ Ezen belül hangsúlyozandó, hogy az iráni népek többségénél megfigyelhető a földbeszúrt kard előtti áldozat bemutatásának szokása, és egyéb, karddal kapcsolatos vallási hiedelmek. A hunok valószínűleg a délorosz steppén először meghódított alánoktól vehették át a kardkultuszt (BACHRACH 1973, 111; MAKKAY 1995, 18-22; MAENCHEN-HELFEN 1997, 203-204). A Priskos fennmaradt töredékében található Árész isten kardja kapcsán pusztán

\footnotetext{
79 „,... drágakövek szikrázzanak az acélon, s a csillogó vasú kardpengéken aranyos fény lángoljon...” (MEROBAUDES 83-84. ford. Olajos 1966, 184)

80 J. Werner „,mágikus kardgyöngyöknek” nevezte ezeket a tárgyakat, úgy vélte, hogy amulettként funkcionáltak, és a kard hatékonyságát, erejét növelték (WERNER 1956, 31-35). Bóna I. ezzel szemben a kardgyöngyök rangjelző szerepét hangsúlyozta (BóNA 1993, 165). B. Anke pedig nem zárta ki annak a lehetőségét, hogy mindkét funkció együttesen szerepet játszhatott a kardgyöngyök használatában (ANKE 1998, 99-100). Sz. I. Bezuglov ellenben gyakorlati rendeltetést tulajdonított a kardgyöngyöknek, véleménye szerint a kardszíj részét képezték ezek a gyöngyök (BEZUGLOV 1997, 135; BEZUGLOV 2000, 172).

${ }^{81}$ A Kubiláj parancsára 1272-1280 körül összeállított Fehér történetben a gyémántos szablya/kard a Mongol Birodalom kilenc jelvénye között szerepel mint a törvény végrehajtásának jelvénye (SAGASTER 1976, 126127).

${ }^{82}$ Szkíták kapcsán Hérodotos emlékezik meg az Árészt jelképező, dombba szúrt kardról, mely előtt áldozatot mutatnak be (HÉrodoTOS IV. 62. vö. Muraközi 2000, 286). A szkítákkal egy időben élt szauromatáknál is megfigyelhető a kard istenként való tisztelete (CLEMENS ALEXANDRINUS, Protrepticus V. 65-66). Ammianus Marcellinus szerint az alánok a kardjukat istenként tisztelték (AMMIANUS MARCELLINUS XXXI. 2. vö. Szepesy 1993, 590). Valamint a hiung-nuknál is megfigyelhető, hogy a kard a háború istenét szimbolizálhatta, akinek hadifoglyokat áldoztak fel (CH’̈̈-HSÜN 1960, 225-226).
} 
csak a szerző által használt Gípos kifejezés alapján következtethetünk egy hosszú, egyvagy kétélü lovassági kardra. ${ }^{83}$

\section{1. 4. Lándzsa}

Csupán csak két szír szerző emlékezik meg egyértelmüen a hunok lándzsáiról (PseudoKallisthenes 264, 265, Pseudo-Ephraem (189) 6. vö. KMOSKÓ 2004, 77, 84-85). Ezenkívül csak néhány bizonytalan adatból következtethetünk a lándzsahasználatra: ilyen a hasta említése (SIDONIUS, Carmina II. 289-292); valamint feltételezhető, hogy az egyértelmüen el nem dönthető fegyverterminusok némely esetben dárdára is vonatkozhattak. ${ }^{84}$

A hasta kifejezést eredetileg a római gyalogság döfö- és dobólándzsájára használták a korabeli szerzők (KOLIAS 1988, 191; COULSTON 2002, 13), de ritkán alkalmazták 'dobódárda' jelentésben is (GLARE 2000, 787), emellett általános jelentéssel is bírt a lándzsára vonatkozólag (FINÁLY 1884, 887). Azonban Sidonius Apollinaris leírásából úgy tünik, hogy Avitus és egy hun harcos lóháton küzdöttek egymással, összecsapásuk során döfölándzsát használtak (SIDONIUS, Carmina II. 289-292). Maga a forrásrészlet a hun harcos esetében nem említ konkrétan fegyvertípust, csak Avitus esetében emlékezik meg pontosan a lándzsáról. Maenchen-Helfen úgy véli, hogy Avitusnak és a hunnak egyforma felszerelésük volt: vértezet és lándzsa (MAENCHENHELFEN 1997, 180-181). Az írott forrásokhoz hasonlóan a régészeti anyagban is kevés lándzsalelet ismert a hun korszakra datálható leletanyagból. ${ }^{85}$ Bóna István szerint ezek a példányok a nehézfegyverzetü lovasság döfőlándzsái lehettek (TOMKA 1993b, 18; BÓNA 1993a, 166; ZASZECKAJA 1994, 35). Dobódárdára utaló lelet még nem került elő a hunokhoz köthető régészeti anyagban. Az írott és régészeti források gyér számából úgy tünik, hogy ez a fegyvertípus nem volt széles körben elterjedt a hun hadseregben (ZASZECKAJA 1994, 35; NiKONOROV 2010a, 268). ${ }^{86}$

\footnotetext{
${ }^{83}$ A középkori hagyomány tévesen a bécsi Kunsthistorisches Museumban őrzött honfoglalás kori szablyát Attila kardjával azonosította (lásd bővebben TóTH 1930; FODOR 2000, 7-20).

${ }^{84}$ Lásd a kérdéses fegyverterminusokról szóló fejezetet.

${ }^{85}$ Két lelőhelyről ismert ez a tárgytípus: Pokrovszk-Voszhod, Pécs-Üszög (BóNA et al. 1993, 18; BóNA 1993, 166; ZASZECKAJA 1994, 35).

${ }^{86}$ A lándzsák kis mennyiségét Bóna István a temetkezési rítussal magyarázza, véleménye szerint az elhunyt sírjára vagy a tiszteletére emelt halomba szúrták ezeket a fegyvereket, és ezért gyér a számuk (BóNA 1993, 166).
} 


\section{1. 5. Pányva}

A hun hadsereg lasszóvetését négy forrás említi: lacinia (AMMIANUS MARCELLINUS XXXI,

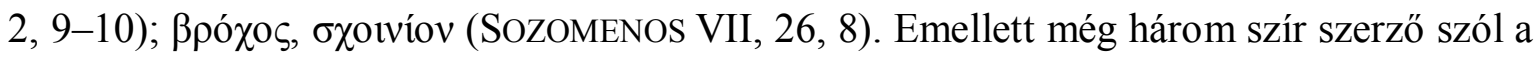
hunok pányvájáról (Pseudo-Kallisthenes 264, Pseudo-Ephraem (189) 6, Josue Stylita 63. vö. KMOSKÓ 2004, 77, 85, 121).

Az Ammaianus Marcellinus által használt lacinia terminus 'szalag' jelentése áll a legközelebb a pányva szóhoz (GLARE 2000, 994). Más nomád népek pányvája esetében nem figyelhető meg ez a terminus. ${ }^{87}$ A $\sigma \chi 0$ ovíov kifejezés pedig egyszerű 'zsinór, kötél' jelentéssel bír, melyet a pányvára is használták (GYÖRKÖSY-KAPITÁNFFY-TEGYEY 1990,

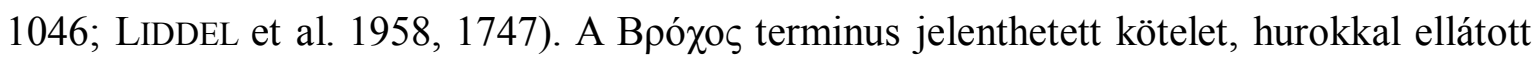
kötelet, pányvát és hálót is (GYÖRKÖSY-KAPITÁNFFY-TEGYEY 1990, 196; LIDDEL et al. 1958, 331). Ez esetben az egyháztörténetíró ugyanazon esemény kapcsán (Theotimos püspök sikertelen elfogása) ugyanazt a fegyvert nevezi két különböző kifejezéssel (SOZOMENOS VII, 26, 8). ${ }^{88}$

A három szír szerző által használt, pányvára vonatkozó kifejezés a prwyē/prwyē, mely szónak legvalószínübb jelentése 'szíj' (KMOSKÓ 2004, 77, 85, 121).

A 2-6. században a délorosz steppei nomád népek jellegzetes fegyvere ${ }^{89}$ volt a pányva, valószínüleg a hunok révén a szomszédos népek is átvették ezt az eszközt. ${ }^{90}$ Ammianus Marcellinushoz mellett Pseudo-Kallisthenes, Pseudo-Ephraem és Josue Stylita müveiből is kitünik, hogy a hunok általános, jellegzetes fegyvere lehetett a pányva (Pseudo-Kallisthenes 264, Pseudo-Ephraem (189) 6, Josue Stylita 63. vö. KMOSKÓ 2004, $77,85,121)$. A lasszót főként az ellenség foglyul ejtésére használták, amikor is váltságdíjat kértek értük, vagy eladták rabszolgának őket (MORAVCSIK 1967, 276-280; SINOR 1981,

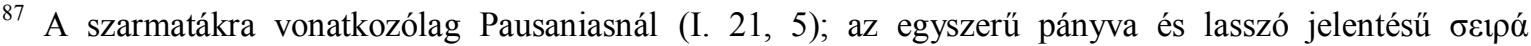
(GYÖRKÖSY-KAPITÁNFFY-TEGYEY 1990, 952), Pomponius Melánál (I. 114) a hurokkal ellátott kötél kifejezés (laqueus) (FINÁly 1884, 1109) található meg. Az alánok pányváját Josephus Flavius ßpóxos terminussal jelöli (JoSEPHUS FlaviUs VII. 4). A Josephus Flavius munkáját felhasználó Pseudo Hegesippus a laqueus terminust használja (PSEUdo HeGesipPus V. 50).

${ }^{88}$ Sozomenos ezzel kapcsolatosan egy érdekes történetet örökített meg, melynek a föszereplöje Theotimos, Tomis város és Scythia Minor püspöke, aki az „állatias” hunokat ajándékaival és vendégszeretetével megszelídítette. Ennek ellenére az egyik hun cselt eszelt ki ellene, és míg miközben a pajzsára támaszkodva beszélgetett a püspökkel, felemelte a karját, hogy pányvát vessen rá, és elfogja. A karja azonban megmerevedett, és addig nem mozdult, míg Theotimos Istenhez nem könyörgött, hogy feloldja a „láthatatlan bilincset" (SOZOMENOS VII, 26, 8; MORAVCSIK 1967, 278).

${ }^{89}$ Pseudo-Hegesippus szerint az alánok nagyon jártasak voltak a pányvavetésben, és jellegzetes eleme volt a harcmodoruknak (PSEUDo HEGESIPPUS V. 50).

${ }^{90}$ Olympiodoros munkájából kiderül, hogy Sarus pányvavetéssel kerül Ataulf gót király fogságába 412-ben (Olympiodoros 18. vö. Blockley 1983, 183). Malalas szerint 435 táján a gót Areobindos perzsa ellenfelét pányvával rántotta le a lováról (MALALAS 364. vö. Jeffreys et al. 1986, 199).
} 
141-142; MAENCHEN-HELFEN 1997, 176-177; GOLDEN 2002, 151). A forrásokban található pányvák/lasszók három típusba sorolhatók. Hérodotos említ egy sagartius nevü

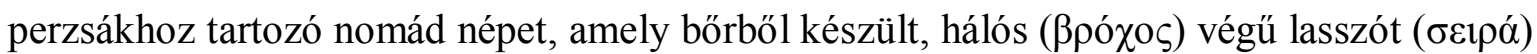
használtak (HÉRODOTOS VII. 85). Ezenkívül még megfigyelhető a forrásokban a botospányva is, melynek a fö része egy néhány méter hosszú rúd, melyre a pányva használója a kezében fogott pányvakötelet néhányszor lazán ráhajtja, a végén kiképzett hurkot pedig a rúd végén levő $\mathrm{V}$ elágazásra akasztja, vagy annak kihegyezett végére szúrja. ${ }^{91}$ A források többsége azonban az egyszerü felépítésű, hurokban végződő pányvákról számol be (például PAUSANIAS I. 21, 5; POMPONIUS MELA I. 114). Ammianus Marcellinus és Sozomenos leírásából és az általuk használt terminusból úgy tünik, hogy az egyszerübb felépítésü, hurkos végü pányvát használhatták a hunok [21. kép] (AMMIANUS MARCELLINUS XXXI, 2, 9-10; SOZOMENOS VII, 26, 8).

\section{1. 6. Páncél}

A hunok vértezetéről két latin és egy görög forrás emlékezik meg: lorica (PACATUS XXXIII. 4); thorax (SIDONIUS, Carmina VII. 289-292); $\theta \omega ́ \rho \alpha \xi$ (ASTERIOS 9). Ezenkívül még Priskos egy részlete utalhat a hunok teljes vértezetére: $\pi \alpha v o \pi \lambda i ́ \alpha$ (SUDA 29). A latin és a görög nyelvü forrásokon kívül a hunok vértezetére egy skandináv sagában, Hervar és Heidrik sagában (Hervarar saga ok Heiðreks) is találunk utalást (TOLKIEN 1960, 52).

A lorica önmagában különféle formájú, változatú páncélt jelölhetett, konkrét típusra nem lehet belőle következtetni ebben az időszakban (GROSSE 1927, 1444-1449). A

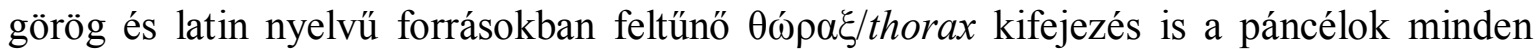
fajtáját jelölhette (sodrony, lemezes, kombinált), nem lehet belöle konkrét típust azonosítani (KoLIAS 1988, 37).

Nagyon jó leírást találunk Sidonius Apollinaris munkájában a hunok vértezetére. A költő szerint egy párbaj során Avitus úgy megsebesített egy hun harcost, hogy a mellkasán

\footnotetext{
${ }^{91}$ Ez a típus a mongoloknál is jól ismert fegyver volt. Temüdzsint például egy alkalommal botos lasszóval üldözték (SHM 91. vö. Rachewiltz 2006, 28). Ezenkívül a mameluk kori források is alátámasztják, hogy a mongolok használtak lasszót a nehézfegyverzetű harcosok nyeregből való kimozdításához (WATERSON 2007, 166). A botospányva használatának néprajzi párhuzamai is vannak, melyekböl úgy tünik, hogy ez a típus elsősorban az állattartásban, a nagyobb testủ állatok befogásában volt használatos. A rudaspányvával biztosabban helyezhették a kötelet az állatok nyakába, mint az egyszerübb felépítésü típussal (SzABADFALVI 1981, 386). Ez az eszköz egy nagyjából embermagasságú bot, melynek felső végéhez egy kis toldalékpálcát erősítenek. A bot felső végén hurok van, melyet oda rögzítettek, a kötél másik vége csúszóhurok kialakítású, mely fel-alá csúszik a boton. A lovas a jobb kezében vagy a hóna alatt fogta ezt az eszközt (RóNA-TAS 1961, 81).
} 
befúródó lándzsa nemcsak a mellkasát, hanem a hátát védő páncélrészt is széttörte. Tehát ebből a párbajleírásából egyértelmüen kitünik, hogy a forrásban szereplő fém vértezet a vesztes hun egész törzsét védhette, nemcsak a mellkasát (SidoniUs, Carmina VII. 289292)..$^{92}$

Priskos Bleda „udvari bolondjáról” feljegyzett részlete a 10. századi Suda

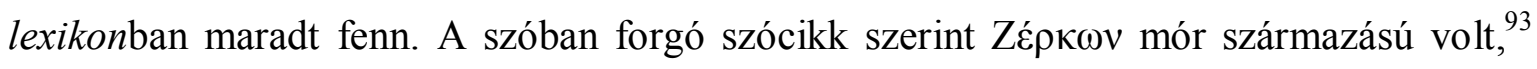
Trákiában került a hunok fogságába, és Bleda közvetlen kíséretéhez tartozott, lakomákra és a hadjárataira is elkísérte urát. Ez utóbbi esetben Zerkón teljes fegyverzetben követte Bledát (SUDA 29). A forrásban található $\pi \alpha v o \pi \lambda i ́ \alpha$ terminust a nehézfegyverzetü gyalogosok teljes fegyverzetére használták, ami magában foglalta a mellvértet, sisakot, lábvértet, lándzsát és a kardot (GYÖRKÖSY-KAPITÁNFFY-TEGYEY 1990, 775; LIDDEL et al. 1958, 1298). Priskos töredékéből kitűnik, hogy Zerkón púpos, nehézkes mozgású, eltorzult lábú volt, így az ő esetében aligha lehetséges, hogy a hadjáratokban aktív szereplöként vett volna részt, és használta volna a fent nevezett támadó fegyvereket. A forrásból kiderül, hogy Bledát nagyon szórakoztatta Zerkón szókimondó, dadogó beszéde, valamint esetlen mozgása, és Attila testvére nagyra tartotta a mór származású alattvalóját (míg Attila látni sem bírta őt) (PRISKOS 13. 2, 1-15. vö. Blockley 1983, 287). Így valószínüsíthető, hogy Bleda a hadjáratok alkalmával kedvenc „udvari bolondját”, azért hogy védje életét, sisakkal, mellvérttel és lábvértekkel láthatta el.

Sem a forrásokban található kifejezésekből, sem a források jellemzéseiből nem tudunk egyértelmüen következtetni a hunok által használt páncélok típusára. ${ }^{94}$ Mivel a Nyugatrómai Birodalommal szövetségben többször vezettek hadjáratokat, felmerülhet annak a lehetősége, hogy a hunok a rómaiaktól vehettek át védőfegyverzetet. Minden bizonnyal feltételezhető ez a lehetőség is. Emellett azonban saját készítésü védőfegyverzettel is számolhatunk a hunok körében. I. Theodosius a trónbitorló Maximus ellen 388-ban vezetett hadjáratakor a keletrómai császár seregében hun lovasság is jelen volt, amely saját felszerelését használta, köztük a nehéz fémvértezetét (PACATUS XXXIII.

\footnotetext{
${ }^{92}$ Hasonló felépítésủ mellvértezetről számol be Prokopios is a nomád Bochas fegyverzete kapcsán. Ez a nomád (a forrás szerint massageta) harcos Justinianus császár hadvezére, Belisar seregében vett részt a gótok ellen vezetett, 535-ben kezdődő hadjáratában (OSTROGORSKY 2003, 76). Prokopios leírásából úgy tünik, hogy Bochasnak is törzspáncélzata lehetett. A forrás szerint vértezete ellenállt a lándzsaszúrásoknak, és a gótok csak úgy tudták megsebezni, hogy sikerült egy olyan helyet találniuk a testén, ahol nem fedte páncél a nomád harcost: a jobb hónalj felett, a váll környékén. Prokopios ezt a páncéltípust $\theta \omega ́ \rho \alpha \xi$ terminussal jelöli (Prokopios, De bello Gothico VII. 2, 22).

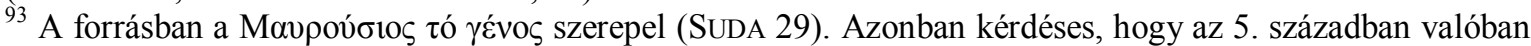
mór származású lehetett-e ez az udvari bolond.

${ }^{94}$ Nikonorov Sidonius leírásából úgy véli, hogy a hun harcos sodronyvértet viselhetett (NIKONOROV 2010a, 270), ezt azonban nem lehet eldönteni a forrásból.
} 
4. vö. Nixon 1987, 42; MAENCHEN-HELFEN 1997, 180). Rátérve a hunok tárgyi hagyatékára, a hozzájuk köthető régészeti anyagban szintén ritka a páncéllelet, mindössze két sodronyvért ismert a délorosz steppéről (ZASZECKAJA 1994, 39). ${ }^{95}$ A vértezet díszítésére Asterios püspök híradásából következtethetünk, miszerint egy hun uralkodó vértje nemesfémből készült, mivel szerinte a barbár fegyverzet pompás és fényüző (ASTERIOS 9). Emellett a skandináv sagában is találunk erre vonatkozólag információt, miszerint a gót helyőrség ellen felvonuló hunok aranypáncélzata a lovaik által felvert porfelhöböl csillogott ki (TOLKIEN 1960, 52). Az, hogy a felvonuló hun hadsereg aranyvértezetben indult volna a harcba, eléggé valószerütlen elképzelés. A forrással kapcsolatban - ha hihetünk ennek a kései kútfőnek - ez a híradás esetleg arra utalhat, hogy a napfényben a hun hadsereg egy részének fémvértezete csilloghatott.

A forrásokból tehát kitűnik, hogy a hunoknak voltak fémvértezeteik, de a régészeti leletek alapján nem lehetett általános használatuk a hun hadseregben. Elsősorban a hun társadalom felsőbb rétege engedhette meg magának, hogy nehézvértezetet viseljen, ezek száma valószínüleg megnőhetett a Keletrómai Birodalom elleni sikeres hadjárat során szerzett évpénzből, zsákmányokból.

\section{1. 7. Sisak}

A hunok sisakját a latin források cassis (MEROBAUDES 83-84) és galea (SIDONIUS, Carmina II. 253-257) kifejezéssel jelölik. ${ }^{96}$ A Suda lexikonban a Zerkón címszó alatt található $\pi \alpha v o \pi \lambda i ́ \alpha$ kifejezés utalhat esetleg a sisakra is (SUDA 29). ${ }^{97}$ Továbbá egy skandináv sagában találunk erre vonatkozólag egy bizonytalan adatot (TOLKIEN 1960, 52).

A galea a római korban 'bőrsisakot' jelentett, a középkorban elvesztette ezt a speciális jelentését, és a sisakra általában használtak ezt a kifejezést (FINÁLY 1884, 843; KOLIAS 1988, 76). Az 5. században élt Sidonius Apollinaris munkájából következtethetünk a hun sisak szerkezetére is. A szerző eléggé terjengős megfogalmazásban leírja, hogy a hun gyermekek arcát hogyan torzítják el az orruk (megcsontosodás előtt) lekötözésével, így

\footnotetext{
${ }^{95}$ Pokrovszk, Fedorovka (ZASZECKAJA 1994, 39).

${ }^{96}$ Emellett Ammianus Marcellinus egyszerủ szörme sapka/süveget (galeri incurvi) említ a hunok esetében (AMmianus MARCELlinus XXXI. 2, 6). Szent Jeromos munkájában található egy tiarae kifejezés (HIERONYMUS 60, 17), ami többnyire csonkakúp formájú, nemezböl készült ázsiai fejviseletet jelentett (GLARE 2000, 1940). Nikonorov szerint ez a szó a hunok sapkájára vonatkozhat (NIKONOROv 2010a, 269). Szent Jeromos leveleinek magyar fordításában is a 'sapka' szó szerepel (ADAMIK-PUSKELY-TAKÁCS 2005, 269). Az egyháztanító azzal, hogy a hun tiarae küllemét összevetette a rómaiak által használt sisakkal (galea), a kettő közötti jelentős különbséget akarta hangsúlyozni (HIERONYMUS 60, 17).

${ }^{97}$ Lásd erre vonatkozólag a páncélzatról szóló fejezetet.
} 
akadályozzák meg azt, hogy az orrhegy kiemelkedjen az arccsontból ezzel lehetőséget teremtve arra, hogy sisakokat használjanak (SIDONIUS, Carmina II. 253-257). ${ }^{98}$ A leírásból úgy tünik, hogy a hunoknak voltak orrvédővel ellátott sisakjaik (is) (MAENCHENHelfEN 1997, 182). ${ }^{99}$ Tehát a galea terminus ez esetben nem bőrből, hanem fémből készült fejvédőre utal.

A cassis kifejezést a római korban a fémsisakokra alkalmazták (FINÁLY 1884, 314; KOLIAS 1988, 76). Erre utal a hunok kapcsán Merobaudes, aki szerint ezek a sisakok aranyozottak voltak (MEROBAUdes 83-84). Mint már korábban volt róla szó, Hervar és Heidrik sagája a hadba induló hun sereget csillogó aranyozott sisakban ábrázolja (TOLKIEN 1960, 52). Ez utóbbi információ forrásértéke eléggé kétséges, inkább nem nemesfémsisakokra gondolhatunk ez esetben. A hunokhoz köthető régészeti anyagban aranyozott sisakot nem ismerünk, viszont Moldovában, Conçestiben egy ezüstözött sisak került elő, amely késő római díszsisak volt. Ezt a példányt Sidonius Apollinaris leírásához hasonlóan orrvédővel látták el (BÓNA 1993a, 166; ZASZECKAJA 1994, 175; COULSTON 2002, 7).

Hasonlóan a páncélokhoz, a hunok sisakjáról kevés forrás emlékezik meg, és ritka a régészeti anyagban is. A hunok közül csak kevesen engedhették meg maguknak a használatukat. Nikonorov szerint a hun társadalom felsőbb rétegéhez tartozók római hatásra vehették át ezeket a drága fémvértezeteket (NIKONOROV 2010a, 269).

\section{1. 8. Pajzs}

A hunok pajzsát csak egyetlen forrás említi ' $\alpha \sigma \pi i ́ s$ (SozOMENOS VII. 6, 8) alakban, emellett a Suda lexikonban található $\pi \alpha v o \pi \lambda i ́ \alpha$ kifejezésből következtethetünk esetleg a pajzsra (SUDA 29). ${ }^{100}$ Ezenkívül egy skandináv sagában találunk még a pajzsukra vonatkozó adatot (TOLKIEN 1960, 52).

Az ógörög ' $\alpha \sigma \pi i \varsigma_{\varsigma}-\mathrm{t}$ a bizánci szerzők általánosan használják, alakjára, típusára pusztán a kifejezésből nem lehet következetni (KoLIAS 1988, 89). Sozomenos azonban leírja, hogy egy hun a pajzsára támaszkodva tárgyalt Theotimussal, Tomis város (ma Constanţa, Románia) püspökével (SozOMENOS VII. 6, 8). Maenchen-Helfen ebböl a forrásrészletből arra következtetett, hogy a forrásban szereplő pajzs hosszú lehetett,

\footnotetext{
${ }^{98}$ A szerző ezzel a leírással a hunok arcának torz küllemére akart rávilágítani.

99 Maga a gyermekek arcának eltorzítása azonban egyértelmüen toposznak tekinthető, Iordanes is megemlékezik a hunok esetében a gyermekeik arcának az elcsúfitásáról (IORDANES, Getica 127-128).

${ }^{100}$ Lásd bővebben a páncélzatról szóló fejezetet.
} 
ugyanis véleménye szerint a hun harcos a földön állt, és így támaszkodott a pajzsára (MAENCHEN-HELFEN 1997, 184). ${ }^{101}$ Ezzel szemben Nikonorov azt hangsúlyozta, a forrásból nem lehet egyértelműen eldönteni, hogy a hun harcos a földön állt vagy pedig lóháton ült (NIKONOROV 2010a, 269). Sozomenos munkájából valóban csak annyi derül ki, hogy a hun, mielőtt megpróbált volna pányvát vetni Theotimusra, a pajzsára támaszkodva beszélgetett Tomis városának püspökével. Nikonorov véleménye szerint, amit az írott források is alátámasztanak, a pányvákat elsősorban lóháton lehetett használni. ${ }^{102}$ Így az orosz kutató úgy véli, hogy a hunoknak könnyü, kisméretü, fából készült, bőrrel bevont pajzsaik lehettek (NIKONOROV 2010a, 269). A görög forrás mellett még a skandináv saga emlékezik meg a hunok pajzsáról, a forrás szerint a hunok - többek között - aranypajzzsal indultak a harcba, ez azonban eléggé valószerütlennek tünik.

\section{1. 9. Kérdéses fegyverterminusok}

A hun fegyverzetre vonatkozólag négy kifejezés található, melyből nem lehet pontosan meghatározni konkrét fegyvertípust: telum (IORDANES, Getica 206; HIERONYMUS LXVII. 8; Vita Aniani 9); ßé̉̇os (Priskos 6, 2); ferrum (Sidonius, Carmina II. 298; VII. 249); iaculum (SIDONIUS, Carmina VII. 236).

A ferrum kifejezésnek nem volt konkrét jelentése, a fegyver szóra általánosan vonatkozott. Ezen belül jelenthetett kardot, dárdát, tőrt (FINÁLY 1884, 788; GLARE 2000, 691). Sidonius egyik költeményében sem lehet eldönteni a szó konkrét jelentését, ugyanis csak általánosságban, töltelékszóként figyelhető meg ennek a terminusnak a használata. Az első esetben a hunok Serdica elfoglalása után ferrummal megölik a szökevényeket (SIDONIUS, Carmina II. 298). A másik esetben pedig a hunok ferrummal pusztították Arvernia/Aquitánia területét (SIDONIUS, Carmina VII. 249). ${ }^{103}$

A telumot, mint azt már a nyíl fejezetben jeleztem, elsősorban távolharcban használatos fegyverekre alkalmazták, lehetett nyíl és dobódárda is (FINÁLY 1884, 1960; Glare 2000, 1911). Kiss Magdolna 'dárda' (KISS 2005, 83), Szkrzsinszkaja pedig 'nyíl' (стрела) jelentésben fordította ezt a kifejezést (SzKRZSINSZKAJA 1960, 107) a Getica ezen részlete kapcsán (IORDANES, Getica 206). A szövegkörnyezetből viszont nem lehet

\footnotetext{
101 A szerző szerint pajzs $75-90 \mathrm{~cm}$ hosszú lehetett (a hun harcos magasságát $160 \mathrm{~cm}$-nek vette) (MAENCHEN-HeLFEN 1997, 184).

${ }^{102} \mathrm{Az}$ írott forrásokból a szkíták, szarmaták és a parthusok pányvahasználatakor a lovas harcmodor tünik ki (HÉrodotos VII. 85. vö. Muraközi 2000, 485; PAUSANIAS I. 21, 5. vö. Muraközi 2000, 34; SudA 278).

${ }^{103}$ Anderson és Nikonorov is 'kard' jelentésben fordította mindkét esetben ezt a terminust (ANDERSON 1963, 33; NIKONOROV 2010a, 267).
} 
egyértelmüen eldönteni, hogy Iordanes nyílra vagy dárdára gondolhatott-e. A forrásrészletet megvizsgálva azonban a hun fegyverekre vonatkozóan nem használható hitelesen az itt szereplő terminus. A kifejezés ugyanis Iordanes által interpretálva Attila mauriacumi/catalaunumi csata közben elhangzott beszédében található. Nem valószínü, hogy Attila ilyen hosszú beszédeket tartott volna csaták közben, ${ }^{104}$ ha beszélt is a harcok során, azok inkább rövid parancsszavak, utasítások lehettek alvezérei számára. ${ }^{105}$ Iordanes nem rendelkezett bővebb információkkal a csatáról, és ilyen beszédekkel igyekezett kitölteni a számára hiányos eseménysort (SCHREIBER 1976, 251-252). A Szent Jeromos 77. levelében található telum kifejezést az egyháztudós a keleten megjelenő hunok támadásai, kegyetlenkedései kapcsán használta (HIERONYMUS LXVII. 8. vö. Adamik-Puskely-Takács 2005, 357), így semmilyen forrásértékkel nem bír a hunok fegyverzete kapcsán. Szent Ányos legendája szerint a hunok a 451-es, Aureliana elleni ostromkor használtak égő telumokat, azért hogy felgyújtsák a város belsejét (VITA ANIANI 9). A lövedék típusára azonban nem lehet következtetni ebből a forrásrészletből. A gyújtólövedékeknek két típusa különíthető el. Ezek lehettek égö nyílhegyek és dárdák is, melyeknek a hegyét olajjal öntötték le, és a lándzsahegy köpüjét gyantával, szurokkal, ronggyal borították be (LÁszLÓ 1909, 778). A forrásból az sem derül ki egyértelmüen, hogy ezt a lövedéket dobták, íjból vagy esetleg torziós hajítógépből lőtték ki.

A ßź̇os kifejezésnek 'nyílvessző', 'hajítódárda' mellett általános 'lövedék' jelentése is ismert (GYÖRKÖSY-KAPITÁNFFY-TEGYEY 1990, 186; LIDDEL et al. 1958, 313). ${ }^{106}$ Priskos Naissus ostromakor emlékezik meg arról, hogy az ostromtornyaikon álló hun harcosok úgy lötték a védőket, hogy azok kénytelenek voltak visszavonulni a mellvédekről (BLOCKLEY 1983, 233). Nikonorov nyílvesszőként fordította a kifejezést (NiKONOROV 2010a, 267), Blockley azonban nem foglalt állást ez ügyben, és az általános jelentéssel bíró lövedék (missile) szót használta a fordításában (BLOCKLEY 1983, 233). Bár valószínűbb, hogy a hunok ostromgépeikről nyílzáport zúdítottak az ellenségre, nem zárható ki, hogy hajítódárdákat is használhattak harc közben. ${ }^{107}$ Míg az előbbire jelentős mennyiségü régészeti anyag áll a rendelkezésünkre, addig ez utóbbit a régészeti adatok nem támasztják alá (ZASZECKAJA 1994, 35).

\footnotetext{
${ }^{104} \mathrm{Az}$ ókori antik történetírásnak egyik jellegzetes eleme a történeti események közé történő fiktív vagy valós alapú beszédek vagy levelek beiktatása (KAZHDAN 1991b, 937-938).

${ }^{105}$ Emellett Schreiber kiemelte, hogy ez a beszéd túlzottan terjengős, ahhoz, hogy a forrásokban kialakult Attila-képhez illeszkedjen (SCHREIBER 1976, 252). Lásd még a mauriacumi csata egyik lábjegyzetét.

${ }^{106}$ Nagyon ritka esetben kard vagy fegyver értelemben is használták az auktorok ezt a kifejezést (LIDDEL et al. 1958, 313)

${ }^{107}$ Vegetius hadászati munkájából kitűnik, hogy az ostromtornyok legfelsőbb szintjein az íjászok mellett dárdákat és köveket hajítók is harcoltak (VEGETIUS IV. 17. vö. Várady 1963, 848).
} 
A iaculum is föként dobódárda jelentésben figyelhetö meg a forrásokban, de általános lövedék jelentése is ismert, valamint nyílvesszőre is használhatták a korabeli szerzők (GLARE 2000, 815). Sidonius munkáinak fordítója, Anderson a dobódárda (javelin) kifejezést használta a kérdéses helyen (ANDERSON 1963, 138-139), míg Nikonorov szerint nyílvesszöre utalhat a terminus (NIKONOROV 2010a, 267). Sidonius ebben a költeményében felsorolja, hogy mely népek vettek részt a 435/436-os burgundok elleni hadjáratban a római hadsereg kötelékében, és köztük szerepel a iaculumot használó hun is. ${ }^{108}$ Mivel másik költeményében a hunok íj és nyílhasználatát emeli ki a szerző - és ezen esetekben is többféle terminust alkalmaz -, valószínü, hogy ebben az esetben is inkább nyílvesszőre kell gondolnunk. A régészeti források is elsősorban ezt támasztják alá (ZASZECKAJA 1994, 35-39).

\section{2. Harcmodor}

A hunok harcmodoráról megemlékező kútfőkre többnyire jellemző, hogy nagyon negatív képet tükröznek a hun harcosokról: vérszomjas, kegyetlenkedő, mindenkit elpusztító, gyermekeknek sem kegyelmező vadállatokként ábrázolják őket (HIERONYMUS LXVII. 8. vö. Adamik-Puskely-Takács 2005, 357). Claudianus a hunokat rút pofájúnak, ocsmány testünek jellemzi (CLAudianus I. 325-326. vö. Mezei 1988, 19). Pseudo-Ephraem szerint pedig ez a nomád nép gyermekhúst eszik, és asszonyvért iszik (Pseudo-Ephraem (189) 6. vö. KMOSKÓ 2004, 77, 85). Ez az ábrázolásmód természetesen más nomád népek esetében is megfigyelhetö.

A hun hadsereg struktúrájára és harcmodorára vonatkozó írott forrásokból arra következtethetünk, hogy a hunoknak voltak felderítőegységeik, könnyü- és esetleg nehézfegyverzetű lovasságuk, valamint gyalogságuk, ostromtechnikájuk. Gyér adatok állnak a rendelkezésünkre a hun csapatok gyakorlásának módjára, esetlegesen a felderítésükre vonatkozóan. Biztosan megállapítható - ahogy más nomád népek esetében is -, hogy a jósoltattak a hadjárat, csata eredményét illetően, továbbá megfigyelhető a hun hadsereg esetében a pszichológiai hadviselés több formája, a hadjáratra vonuló sereg táborának a védelme. A hun uralkodók közül Attila esetében vannak adataink a

\footnotetext{
${ }^{108}$ A hunok mellett még Sidonius megemlíti az úszó frankokat, a futó herulokat és a pajzsot használó szarmatákat is (SIDONIUS, Carmina VII. 236. vö. Anderson 1963, 138-139). Hasonló jellegü felsorolás található Iordanesnél a nedaói csata leírásánál, ahol a hunok ellen felkelt segédnépeket sorolja fel a szerző (IORDANES, Getica 261. vö. Kiss 2005, 94).
} 
testőrségére vonatkozólag. Az írott forrásokból valamelyest következtethetünk hadi szerveződésükre, létszámukra is.

\section{2. 1. Hadjáratra, csatára történő felkészülés}

A hadjáratra, csatára történő felkészüléshez soroltam a gyakorlást, a felderítés különböző módjait, a hadjárat/csata végkimenetelére irányuló jóslási formákat, valamint a folyón történő átkelés és az utánpótlás problematikáját. A felderítés kapcsán fontos hangsúlyozni, különböző módon nyilvánulhatott meg attól függően, hogy egy tervezett hadjárat érdekében vagy pedig már egy zajló hadjárat közben történő hírszerzésről van szó. Ami a jóslást illeti, a hadjáratok tervezésekor is kikérhették az égiek véleményét, de a hadjárat közben, egyes csatákat megelőzően szintén jósoltathattak. A hunok esetében a folyón történő átkeléssel kapcsolatban több változat is megfigyelhető a forrásokban, csakúgy, mint az utánpótlás problémáját is többféleképpen oldották meg a hunok.

\section{2. 1. 1. A gyakorlás}

Annak ellenére, hogy néhány szerző (például Ammianus Marcellinus) a hun hadsereg szervezetlenségére utal. Ezzel szemben ahhoz, hogy az általuk alkalmazott harcmodort, taktikai elemeket sikeresen meg tudják valósítani, szükséges volt a fegyelem és gyakorlás. ${ }^{109}$ A nomád népek esetében megfigyelhető, hogy a vadászat nemcsak élelemszerzés szempontjából volt fontos, hanem ezeken az eseményeken gyakorolták a különböző taktikai elemeket is (GOLDEN 2002, 132-133). ${ }^{110}$ A hunoknál is találunk a vadászatra történő utalást Priskos munkájában, miszerint Attila a Dunán átkelve, a folyó túlsó, déli partján akart vadászni (PRISKOS 11. 2, 75-78). ${ }^{111}$

\footnotetext{
109 Theophylaktos Simokattés említi meg, hogy az ogurok többek között azért olyan erős nép, mert a fegyverforgatást gyakorolják (THEOPHYLAKTOS SIMOKATTÉS VII. 6, 13. vö. Olajos 2012, 245).

${ }^{110}$ Maurikios részletesen beszámol az avarok vadászatának a mozzanatairól és arról, hogyan alkalmazzák és gyakorolják a csatákban használt taktikai elemeket (MAURIKIOS XII. 10, 5, 7, 8, 33. vö. SzÁDECZKYKARDOSS 1998, 84). Emellett a hiung-nuk vadászatát Szema-Kien említi meg a nomád nép általános jellemzésekor, valamint szintén a Si-ki-ben maradt fenn, hogy Mao-tun a parancsnoksága alá tartozó embereivel egy vadászat alkalmával halálra nyilazta apját, Tou-mant, és így szerezte meg a sanjü címet (SzEMA-KIEN vö. Du Yaxiong-Horváth 1997, 17, 33). A honfoglaló magyarok esetében Regino (Regino vö. HKIF 198), a mongolok kapcsán pedig Rubruk és Plano Carpini emlékezik meg a vadászatukról (Rubruk V. 4. vö. GYÖRFFY 1965, 127; Plano Carpini IV. 10. vö. GYÖRFFY 1965, 68).

${ }^{111}$ Priskos mellett még Iordanes említi meg a hunok vadászatait. A gót származású szerző azonban korábbi auktoroknál megtalálható toposzokat alkalmazva primitív barbár hordaként ábrázolja ebben a caputban a hunokat, akik a vadászaton és a fosztogatáson kívül máshoz nem értettek (IORDANES, Getica 123. vö. Kiss 2005, 67).
} 
Több nomád nép esetében megemlékeznek arról az auktorok, hogy már gyermekkorukban elkezdenek lovagolni és íjazni tanulni. ${ }^{112}$ Sidonius a hunok kapcsán erős sztereotípiákat használva csak utal erre azzal, hogy gyermekkorukban is inkább lovagolnak, minthogy saját lábukon tanulnának meg járni (SIDONIUS, Carmina II. 262263). Arra vonatkozóan, hogy a hunoknál mikor válik egy gyermek harcossá, férfivé, a skandináv Hervar és Heidrik sagában (Hervarar saga ok Heiðreks) találunk utalást. A forrás szerint a hunok közül minden 12 év feletti férfi részt vett a gótok elleni háborúban, vagyis a 12. életévét betöltött gyermek ekkor vált felnőtté, harcossá. Az 5-10. századi eurázsiai steppei népek körében a férfivé avatás, a felnőtté válás egyik jelképe a veretes öv volt, ${ }^{113}$ melynek viselésével az adott közösség teljes jogú tagjává vált az ifjú (U. KÖHALMI 1972, 113-114). A veretes övek mellett a férfivé válásnak egy másik jelképe volt az, hogy új nevet, férfinevet vett fel a gyermekneve helyett (Kül Tegin felirat K 30-31. vö. BERTA 2004, 197; Közsilig-pusztai felirat vö. KAKUK 1985, 25). Azonban pontos életkorra vonatkozó adat nem találtam az írott forrásokban, mindenestre elsősorban a tízes éveiknek az első felére tehető a férfivé avatás időpontja. ${ }^{114}$

\section{2. 1. 2. A felderítés}

Ahhoz, hogy a steppei népek sikeresek legyenek hadjárataikban, a hadi taktikájukon és fegyverzetükön kívül szükséges volt számukra, hogy kellőképpen tájékozottak legyenek a célba vett területről, népről. Így fontos szerep jutott a felderítésnek és azoknak a katonai intézkedéseknek, melyek a tényleges katonai akciót megelőzték (GÖCKENJAN 2001, 58). ${ }^{115}$

\footnotetext{
${ }_{112}$ A hiung-nuk gyermekkorukban juhokon tanultak meg lovagolni, madarakra és patkányokra nyilaztak gyakorolásképpen, nagyobb korukban pedig rókára és nyúlra céloztak (SZEMA-KIEN 1. vö. Du YaxiongHorváth 1997, 17). Regino a honfoglaló magyarok kapcsán említi meg, hogy gyermekeiket íjazni tanították (Regino vö. HKIF 199). Plano Carpini szerint a mongolok a gyermekeiket már két-hároméves korukban lovagolni és íjazni tanították (Plano Carpini IV. 10. vö. GYÖRFFY 1965, 68).

${ }^{113}$ A öv steppei nomád népeknél betöltött szerepéről és jelentőségéről lásd GöCKENJAN 2007, 359-394.

${ }^{114}$ A férfivé válás időpontjára vonatkozóan a türköknél Bilge kagán hadvezér testvéréről orhoni feliratában találunk utalást, miszerint Kül Tegin 7 éves korában halt meg az apja, a kagán, és Kül Tegin 16 éves korára már több hadjáratban részt vett. Tehát Bilge kagán testvére és hadvezére e két év között ,találta meg a férfi nevét," vagyis ekkor vált férfivá (Kül Tegin felirat K 30-31. vö. BERTA 2004, 197), vagyis 7 és 16 éves kora között valamikor vált férfivá, felnőtté. (Kakuk Zsuzsa fordításában szerepel az is, hogy tíz éves korában vette fel Kül Tegin a férfinevét (Kül Tegin K 30-31. vö. MEH 66; GYÖRFFY-KAKUK-NÉMETH 1996, 26)). Ez a mai szemmel korainak tekinthetö felnőtté avatás szokása azonban nem steppei nomádokra jellemző sajátosság, hanem ebben az időszakban általános jelenségnek tekinthető a letelepült kultúrákban is. A Bizánci Birodalomban például a felnőttkor a társadalmi felelősség elérésével 15-17 éves korban kezdődött (RAUTMAN 2006, 9). A Ruszban figyelhető meg, hogy a fejedelemfi 3 évesen lóra ült, 7 évesen írni-olvasni tanult, 12 évesen pedig az első hadjáratára ment (DIMNIK 1994, 40).

${ }^{115}$ Más nomád népeknél jóval több információt találunk a felderítésre vonatkozólag. A türkök különbséget tettek a távol fekvő területeket és a közvetlen környezetet fürkésző hadiegységek között Az előbbiek akár több hónapot is eltöltöttek ellenséges területeken, hogy az ellenséges népröl információkat gyüjtsenek.
} 
A hunok támadásai is jól meg voltak szervezve, hírszerzés útján begyüjtött információk alapján tervezhették hadjárataikat. Erre jó példa a 447-es hadjárat, amikor is az AlsóScythia és Moesia elleni hun támadás közben jelentős természeti csapás érte a Keletrómai Birodalmat: Thrákiát, Helléspontost és a Kykládokat hatalmas földrengés rázta meg. Konstantinápolyban a várost védő falak jelentős szakaszon leomlottak, valamint több, a földrengés zónájába eső város, település megrongálódott. Attila a hadjárat során ezt a helyzetet próbálta kihasználni, a hun uralkodó azonban megkésett a seregével, és mire Konstantinápolyhoz ért, a rómaiak már helyreállították a falakat (BÓNA 1993a, 75; THOMPSON 2003, 81-82).

\section{2. 1. 3. A jóslás}

A hadjárat, csata előkészületeihez tartozott a sámánok jóslása annak érdekében, hogy kiderüljön: ki kerül ki győztesen az ütközetből. ${ }^{116}$ A hunok esetében is megfigyelhető ez a jelenség. A mauriacumi csata előtt Attila béljóslásból és a csontokon látható karcolatokból történő jövendölésből próbálta megtudni, hogy ki nyeri meg a csatát (IORDANES, Getica 195-196. vö. Kiss 2005, 80-81). A Iordanes által említett jóslások közül a csontból történő jövendölés ismert szokás volt a nomád népeknél. Mongol kori leírások szerint a csontokat megégették, és a feketére égett csontokon látható hasadások alapján döntöttek az adott kérdésben: ha egyenes vonalban hasadtak meg, akkor az arra utalt, hogy az égiek is támogatják a dolgot (Rubruk XXIX. 23. vö. GYÖRFFY 1965, 176). ${ }^{117}$ Valószínűsíthető, hogy a hunok is hasonlóan végezhették a csontok jóslásra való elökészítését, vizsgálatát. Iordanesnél fennmaradt egy másik jóslási mód: a béljóslás (haruspex: IORDANES, Getica 195-196) során az áldozati állatok belső szerveit, de főként a májat vizsgálták meg, és

Fontos feladatuk volt még, hogy „nyelveket” fogjanak és információkat szerezzenek tőlük. Az utóbbi egységeknek az ellenség csapatmozgását, manővereit kellett figyelniük. Hasonló jelenség figyelhető meg a mongoloknál is: előzetes hadjáratot indítottak a célba vett nép vagy ország ellen: de nem a terület katonai megszállása vagy a nép behódoltatása miatt, hanem a tervbe vett későbbi hadjárat számára akartak információkat gyüjteni. A mongolok előőrseinek a feladata az volt, hogy a hadsereg számára feltérképezzék az ismeretlen területeket (BERTA 1992, 20-26; GÖCKENJAN 2001, 60; VÉR 2012, 147-150).

${ }^{116}$ A 9. században a bulgárok esetében figyelhető meg a forrásokban, hogy csata előtt bűbájt, varázslást, jövendölést végeznek (NICOLAI I. PAPAE Epistolae 35). A mongolok kapcsán Rubruk emlékezik meg arról, hogy a sámánok jelölik ki a hadivállalkozásaikra alkalmas vagy kedvezőtlen napokat, az ő jóslataik nélkül nem indítanak háborút (Rubruk XXXV. 2. vö. GYÖRFFY 1965, 202). A hiung-nuk esetében megfigyelhető a Si-ki-ben, hogy elsősorban telihold alkalmával indítanak háborút, holdfogyatkozáskor pedig visszavonják a seregeiket (SzEMA-KIEN vö. Du Yaxiong-Horváth 1997, 41). A türkök papjairól/sámánjairól Theophylaktos csak általánosságban jelenti ki, hogy jósolni is képesek (THEOPHYLAKTOS SIMOKATTÉS VII. 8, 15. vö. Olajos 2012, 249).

${ }^{117}$ Rubruk szerint a mongol kán semmiben sem döntött anélkül, hogy a csontoktól tanácsot ne kérne (Rubruk XXIX. 23. vö. GYÖRFFY 1965, 176). A Mongolok titkos története szerint a jóslást lapockacsontokkal végezték el (SHM 272. vö. Rachewiltz 2006, 202-205). 
ezekből a jelenségekből jósoltak. Ez a jövendölési metódus elsősorban a Római Birodalom vallási szertartásaiban figyelhető meg, ${ }^{118}$ de a nomád népeknél ritkán találkozunk ezzel a szokással. Maenchen-Helfen Iordanes munkájának fentebb említett részletét összekapcsolta Prospertiro munkájában található egyik adattal. A forrás szerint Litorius seregét 439-ben legyőzték a vizigótok, és az auktor szerint azért következett be ez a vereség, mert Aetius hadvezére megbízott a béljóslás eredményében. Maenchen-Helfen átértelmezte a forrásban rejlő információkat, mivel ebben az időszakban már a Római Birodalomban visszaszorult a béljóslás szokása, így a szerző úgy vélte, hogy nem Litorius, hanem a hun segédcsapata bízhatott a béljóslás eredményében (MAENCHEN-HELFEN 1997, 195-196). A csata győztesére irányuló jóslási/jövendölési módok közül még meg kell említenem a csata közben észlelt égi jeleket. Erre jó példa Aquileia (ma Olaszország) ostroma, amely hosszan elhúzódott, és Attila már az ostrom felhagyásán gondolkodott, amikor egy „égi jelet” látott. Az Aquileiában fészkelő gólyák fiókáikkal együtt elhagyták a várost. A hunok uralkodója úgy értelmezte a jelenséget, hogy a madarak megérezték a fenyegető veszélyt, és ezért költöztek el. A forrás szerint ennek hatására újból támadásba lendültek a hunok, és elfoglalták a várost (IORDANES, Getica 219-224. vö. Kiss 2005, 85). Valószínüleg ebben az esetben is éppen fordítva értendők az ok-okozati összefüggések. Iordanes szerint a sokáig elhúzódó ostrom miatt a harcosok már lázadoztak, és valószínüleg Attila ezzel a csellel (égi jellel) lelkesítette fel őket a támadás folytatására (SCHÄFER 2001a, 25).

A hunok esetében, ahogyan más nomád népeknél is feltételezhető, ${ }^{119}$ hogy a sámánok varázslással próbálhattak kárt okozni az ellenség hadseregében (NIKONOROV 2010a, 280).

\footnotetext{
${ }^{118}$ A rómaiaknál etruszk hatásra jelent meg a béljóslás szokása. A haruspexek fontos szerepet töltöttek be a római vallási szervezetben, és csak a kereszténység térhódításával veszítettek jelentőségükből. Diocletianus (244-311) idején még szerepet játszottak a keresztényüldözésben, azonban a későbbi uralkodók rendeletei hatására, valamint amiatt, hogy az egyre inkább teret hódító keresztény teológia a béljóslást minden más jóslási és mágikus tevékenységgel együtt a fekete mágia közé sorolta, egyre jobban kiszorultak Rómából (LINDERSKI 1996, 667-668).

${ }^{119}$ A sámánok a csaták előtt az időjárást is próbálták befolyásolni, ítéletidőt hozni az ellenségre, ezzel segítve saját hadseregüket a győzelemre. Ez az elképzelés, hogy az időjárás-varázslattal le lehet győzni az ellenfelet, már az 5. századtól adatolható a belső-ázsiai nomád népeknél, és megfigyelhető a későbbiek során is török és a mongol nyelvủ népeknél is. Molnár Ádám mutatott rá arra, hogy ezzel a jelenséggel kapcsolatban az okokozati összefüggések fordítva értendők. Valójában ez egy nomád haditaktikai elem, aminek a lényege, hogy az ellenséget a vihar, ítéletidő alatt támadják meg, vagy röviddel azután, hogy az ellenséges sereget az időjárás viszontagságai meggyengítették (MOLNÁR 1993, 140-144). Erre lehet példa a hunok esetében fentebb már megemlített 447-es, Keletrómai Birodalom elleni hadjárat.
} 


\section{2. 1. 4. A folyón történő átkelés}

Az eurázsiai steppei nomád népeknek hadjárataik során komoly nehézségeket okozhatott a jelentősebb nagyságú folyókon történő átkelés. Ezeket a folyókat vagy kikerülték, vagy felderítőik információi alapján gázlókon, esetleg hidakon keltek át. Télen megvárták a folyók befagyását, vagy a folyó mellett élő népek vízi jármüveit vették igénybe, esetleg saját maguk is készíthettek ilyen eszközöket (FELFöLDI 2004, 75-86). E két utóbbi lehetőségre a hunoknál is találunk példát. Sidonius a Serdica elleni támadáskor említi meg, hogy a hunok a befagyott Dunán keltek át (SIDONIUS, Carmina II. 269-271). ${ }^{120}$ Priskos két helyen is megemlékezik a munkájában a folyón történő átszállítás módjáról. Először a Római Birodalmat a hun fennhatóság alatt álló területektől elválasztó Dunán való átkelést jegyezte fel, másodszor pedig már „barbár” területen jutottak át három folyón, melyek a Dunánál kisebb méretűek voltak (Drecon, Tigas, Tiphesas). Kétféle szerkezetről számol be a görög szerző: ${ }^{121}$ fatörzsböl készült/kivájt csónakokat és tutajokat ( $\left.\sigma \chi \varepsilon \delta i ́ \alpha\right)$ említ. ${ }^{122} \mathrm{Az}$

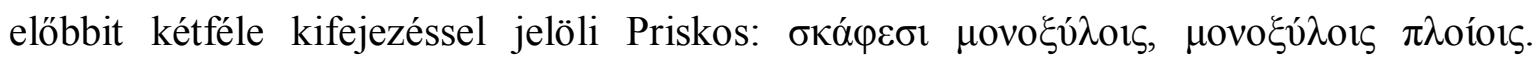
Mindkettő fatörzsből kivájt egyszerü csónak jelentéssel bír. Emellett a tutajok kapcsán a keletrómai szerző munkájából még kiderül, hogy a mocsaras területeken ezek használata nehézkes lehetett, ezért ezeket az eszközöket a problémás helyszínekről szekereken szállították el. A dunai átkelést leíró részlet fontos, hadászattal kapcsolatos információkat rejt. Priskos szerint ezek a csónakok és a barbár révészek azért tartózkodtak a Dunánál, hogy Attila seregét szállítsák át, mert a hun uralkodó újabb támadást tervezett a Római Birodalom ellen. ${ }^{123}$ Mindkét részletben a révészeket barbároknak nevezi Priskos (PRISKOS

\footnotetext{
${ }^{120}$ Hérodotos a szkíták kapcsán említi meg, hogy a Boszporusz és környékének befagyásakor a befagyott jégen vonulnak hadba (HÉRODOTOS IV. 28. vö. Muraközi 2000, 275). Sidonius nagyon költöien fogalmazta meg az átkelést: ahogy szekereken átkeltek a Dunán, úgy a nedves vízen keréknyomokat lehetett megfigyelni (SIDONIUS, Carmina II. 269-271).

121 Sinor Dénes, aki összegyüjtötte a steppei népek által használt vízi jármüvekre vonatkozó adatokat, alapanyaguk szerint osztotta fel ezeket az eszközöket: bőrből és fából készült szerkezetekre. A fából készült vízi szállítóeszközök csoportjában megtaláljuk a szálfákból vagy nádból készített tutajokat és a fatörzsből kivájt csónakokat is (SINOR 1961, 156-157, 162).

${ }_{122}$ A tutajra például a Mongolok titkos történetében találhatunk még példát, ahol a merkit fogságban lévő Börtének a kiszabadítására induló Temüdzsin csapatával a Kilko folyón a saját maguk készítette tutajokon kelt át. A tutajkészítés kapcsán egy alkotóelemet is megemlít a forrás, a szakal-baja-füvet. A mongol tutajokat alapvetően nem farönkökből építették, hanem vesszőkötegekből vagy rőzsenyalábokból. A szakalbaja-fü ennek a vízi eszköznek az alkotóeleme vagy vízhatlanító rétege lehetett (SHM 105, 109. vö. Rachewiltz 2006, 35-37, 39-40; SINOR 1961, 162; FELFÖLDI 2004, 85).

${ }^{123}$ Ezzel a forrásrészlettel kapcsolatban fontos észrevételeket tett Salamon Ferenc. A 19. században élt történész úgy vélte, hogy Priskos munkájának másolója hibát vétett, és az eredeti szövegben nem a fatörzsből kivájt csónak szerepelhetett. Véleményét azzal indokolta Salamon Ferenc, hogy a keletrómai követség lovait, poggyászait, szekereit nem lehetett volna ilyen kis lélekvesztőkön átszállítani a Dunán. Ezért inkább tutajokat vagy valamiféle kompszerü eszközöket feltételezett az eredeti szövegben (SALAMON 1881, 11-12).
} 
11. 2, 71-72; 11. 2, 274), akik lehettek akár hunok, akár a hunok valamely alávetett népe. $^{124}$

\section{2. 1. 5. Az utánpótlás kérdése}

A hadsereg utánpótlása esetében a tartalék lovak, élelem, fegyverek, sátrak és az ostromeszközök egyes részeinek a biztosítása volt a legfontosabb feladat. ${ }^{125}$ A hunok kapcsán viszonylag kevés adatot találunk erre vonatkozólag. A források többsége kiemeli a hunok kapcsán, mint ahogy más nomádok esetében is, ${ }^{126}$ hogy csak a fosztogatáson, rabláson jár az eszük (AMMINAUS MARCELlinUS XXXI. 2, 8, XXXI. 3, 1-2. vö. Szepesy 1993, 587, 590; Sidonius, Carmina VII. 248; Claudianus I. 326. vö. Mezei 1988, 19; PRISKOS 9. 3, 39-53; THOMPSON 2003, 77-78). Tehát a toposzok túlzott hangsúlyossága mellett is következtethetünk arra, hogy a hunok az utánpótlás egy részét helyben, rablással oldották meg. Emellett az élelembeszerzés egy részét vadászatból is megoldhatták. ${ }^{127}$ Ezzel párhuzamosan minden bizonnyal a számukra szükséges dolgok egy részét magukkal is vihették. ${ }^{128}$ Erre utal a forrásokban néhány helyen fellelhető szekerek említése is. Sidonius a Serdica elleni támadáskor utal arra, hogy a hunok a befagyott Dunán szekerekkel keltek át (SIDONIUS, Carmina II. 269-271). Valamint a mauriacumi csata esetében figyelhető meg, hogy Attila a hadsereg táborát szekérsánccal övezte (IORDANES, Getica 210. vö. Kiss 2005, 83; PAUlus Diacouns, Historia Romana XIV. 7). ${ }^{129}$ Az utánpótlásuk fontos elemét képezte a tartalék lovak biztosítása a hadjáratok során, ami mind a közlekedésben, mind a harcászatukban nélkülözhetetlen volt. A tartalék lovakat többnyire vitték magukkal a hadjáratukra. ${ }^{130}$ Zosimos pedig az al-dunai ,szkíták” elleni támadás kapcsán szintén megemlíti a tartalék lovak jelenlétét a hun hadseregben (Zosimos IV. 20, 4. vö. Rebenich

${ }^{124}$ Sinor Dénes egyértelműen állást foglal a kérdésben azzal, hogy a nomádok saját készítésủ vízi jármüveinél sorolja fel ezeket a hunok által használt eszközöket (SINOR 1961, 162).

${ }_{125}$ A középkori európai hadseregek utánpótlásának problematikájára lásd további irodalommal: VESZPRÉMY 2000.

${ }^{126}$ Erről a jelenségről számos forrás megemlékezik. Például a honfoglaló magyarok esetében Ekkehard (Ekkehard 3. vö. HKIF 248-249)

${ }^{127}$ A mongoloknál Marco Polo utal erre a hadjáratközbeni élelemszerzési módra (MARCO POLO 54. vö. Vajda 1984, 121).

${ }^{128}$ Marco Polo a mongolok esetében számol be részletesen arról, hogy nagyobb hadjáratok alkalmával harcosonként 18-18 lovat, sátrat visznek magukkal, továbbá megemlékezik róla, hogy milyen „tartós élelmiszereket" (szárított tejfajtát) visznek magukkal a mongolok (MARCO POLO I. 54. vö. Vajda 1984, 122 123).

${ }^{129}$ A honfoglaló magyaroknál Ekkehard tesz említést a szekereikröl és málháikról (Ekkehard 3. vö. HKIF 251).

${ }^{130}$ Az avarok és a honfoglaló magyarok tartaléklovaira, málháira Maurikios és Bölcs Leó hadászati munkáiban találunk részletes leírást. Lásd az avar harcmodor utánpótlásról szóló fejezetét. 
1990, 169). Elsősorban a Nyugatrómai Birodalommal szövetségben végrehajtott hadivállalkozásaik esetében feltételezhető, hogy a rómaiak biztosították számukra az ellátmányuk jelentős részét. Erre vonatkozólag jó példát találunk Zosimos munkájában, aki szerint 409-ben 10 ezer hun harcost jelent meg Itáliában Alarich ellenében a római császár szövetségeseként. Az auktor megemlékezik arról is, hogy a római uralkodó elrendelte, a hun csapat ellátása érdekében Dalmátiából hozzanak ellátmány, élelmet. A forrás szerint gabonát, juhot és ökröt kellett szállítaniuk a hun sereg élelmezésére (ZOSIMOS V. 50, 1. vö. Rebenich 1990, 255).

\section{2. 2. A csaták közbeni jelenségek}

A csaták közben megfigyelhető, fontos jelenségekhez sorolható a hun hadsereg hadrendje, létszáma, melyekről rendkívül kevés információnk van, a katonai jeladások különböző módjai és ezek szerepe, a hadsereg táborának védelme. Ezenkívül érdemes megvizsgálni, hogy a hunok esetében mennyire érhetők tetten a pszichológiai hadviselés különbözö formái.

\section{2. 2. 1. A hadrend, létszám}

A hunok csatarendjére kevés adatot szolgáltatnak a kútfők. Iordanes - a mauriacumi csata kapcsán - arról tájékoztat, hogy a római-gót sereg ellen felállt hun csapatnak volt jobb és bal szárnya, valamint derékhada. A hunok a centrumban helyezkedtek el, míg a segédnépek az oldalszárnyakon kaptak szerepet (IORDANES, Getica 198. 199. vö. Kiss 2005, 81). Ammianus Marcellinus pedig azt hangsúlyozza, hogy nem egységes arcvonalban álltak fel a csatában, hanem ék alakú rendben kezdték meg a harcot (Ammianus MARCellinus XXXI. 2, 8. vö. Szepesy 1993, 587). Ez az ék alakú szerveződés szétszóródó, több egységből álló, laza csatarendet jelentett. ${ }^{131}$

Míg a hun hadsereg létszámával kapcsolatban az egyik legmegbízhatóbb forrásunk csak arról tájékoztat, hogy jelentős volt Attila serege (PRISKOS 11. 2, 615-619), addig néhány auktor számadatokat is közöl a hun hadseregről. Sokrates munkájában a burgundok elleni összecsapás kapcsán a hun halottak számát örökítette meg, szerinte 10 ezer hun harcos esett el a csatában (SOKRATES VII. 30, 108. vö. Baán 1984, 455). Zosimos szerint

${ }^{131}$ Az ék alakú csatarendről lásd bővebben a könnyüfegyverzetű lovassággal foglalkozó fejezetet. 
10 ezer hun harcolt Alarichhel szemben a római császár szövetségeseként (ZosiMOS V. 50, 1. vö. Rebenich 1990, 255). A szerző emellett utal arra, hogy az ekkora nagyságú hadsereg ellátását biztosítandó Honorius császár (395-423) Dalmácia területéről hozatott élelmet. Jóval kisebb létszámú seregről számol be Zosimos, aki Olympiodoros munkáját használta fel. Szerinte Honorius császár minisztere, Olympius vezetésével 409-ben 300 fős hun sereg támadta meg, és győzte le a gótokat (Zosimos V. 45, 6; VÁcZI 1986, 74). Philostorgios sokkal jelentősebb létszámadatot közöl, szerinte 425-ben Aetius jóvoltából 60 ezer hun harcos jelent meg Itáliában (PHILOSTORGIOS XII. 14). A legnagyobb számadat Iordanesnél olvasható, aki 451-ben 500 ezer före teszi a Mauriacumnál felvonuló hun sereg létszámát (IORDANES, Getica 182. vö. Kiss 2005, 78). ${ }^{132}$ Szintén Iordanesnél található egy számadat, ami szerint a nedaói csatában 30 ezer hun és velük szövetséges harcos esett el (IORDANES, Getica 262. vö. Kiss 2005, 94). Thompson szerint a felsorolt források adatai erösen túlzóak, úgy véli, hogy a római provinciákba betörő hun csapatok, valamint a rómaiak által felbérelt hun zsoldos csapatok létszáma nem lehetett 1200 fönél több. A 425-ben Itáliába vonuló hun sereg esetében pedig a 6000 föt feltételez. Thompson teljesen irreálisnak tartja Iordanesnek a mauriacumi csatánál említett létszámadatát (THOMPSON 2003, 50-51). Bóna István ez utóbbi esemény kapcsán maximum 30-50 ezer fös hadsereglétszámot rekonstruált (BÓNA 1993a, 86). Bernard S. Bachrach hasonlóan 40-50 ezer fös hun sereget feltételez a mauriacumi csata kapcsán (BACHRACH 1994, 64-67). ${ }^{133}$ Tekintetbe véve, hogy egy ekkora seregnek mekkora ellátásra, utánpótlásra van szüksége, Kiss P. Attila ezzel szemben azt hangsúlyozta, jóval kevesebben vehettek részt ebben a hadjáratban (KISS P. 2010a, 152). A nedaói csata leírásakor Iordanes által megemlített 30 ezer elesett hun harcos számadatából Nikonorov úgy véli, hogy a csatában részt vett teljes hun hadsereg 45-60 ezer fös lehetett (NiKONOROV 2010a, 281). ${ }^{134}$ A steppei nomád népek hadi szerveződése tízes rendszeren alapult, hasonlóan más népekhez a hadseregük századokból, ezredekből, tízezredekből épült fel, ez utóbbi török neve a tümen (ZIMONYI 2004, 108;

\footnotetext{
${ }^{132}$ Bár maga a gót származású szerző is bizonytalannak tünik a számadat kapcsán: „,Azt beszélik, hogy serege 500000 fö volt." (IORDANES, Getica 182. vö. Kiss 2005, 78)

${ }^{133}$ Bachrach úgy véli, hogy az ellenfél esetében a vizigót sereg 20-25 ezer, a római sereg pedig 25-35 ezer fös lehetett (BACHRACH 1994, 62).

${ }^{134}$ Veszprémy László a középkori forrásokat hadászati szempontból megvizsgálva az európai hadviselés kapcsán kiemelte, hogy Vegetius munkásságát követően a 16. századdal bezárólag nem rendelkezünk hadászati munkával (kivéve a Bizánci Birodalmat), és csak olyan források állnak a rendelkezésünkre, melyek lejegyzői hadászatban nem voltak jártasak. Ezekből a forrásokból kitünő létszámadatok rendkívül bizonytalanok, nehezen értelmezhetőek (VESZPRÉMY 2000, 106-117; VeSZPRÉMY 2006, 517-523). A korszak hadilétszámra vonatkozólag összehasonlításképpen érdemes megemlíteni a 4. század végén, 5 . század első felében élt szerzö, Vegetius hadászati munkáját, melyből kiderül, hogy a római sereg kisebb hadjáratoknál 10 ezer gyalogosból és 2000 lovasból, nagyobb hadjáratok esetében 20 ezer gyalogosból és 4000 főnyi lovasságból állt (VEGETIUS III. 1. vö. Várady 1963, 798).
} 
ZIMONYI 2005, 89-90). A hunok esetében is ezt a hadi szerveződést feltételezhetjük. Érdemes egy eddig az adott témában kevésbé idézett forrást is bevonni a hunok hadszervezetének és hadserege létszámának a vizsgálatába. ${ }^{135}$ A kései keletkezésű skandináv Hervar és Heidrik sagában (Hervarar saga ok Heiðreks) a hunok és a gótok között a 4. században lezajlott háború olvasható. A forrás szerint a hunok az összes 12 év feletti férfit toborozták a háborúba, és részletesen megemlékezik a hunok hadszervezetéről: a legnagyobb egység a fylki, melyböl hat van, ${ }^{136}$ minden fylki 5-5 ezredet tartalmaz, és minden ezredben 13 század található. Egy századot pedig négyszer 40 harcos alkot (TOLKIEN 1960, 52). Tehát a forrásban található információk alapján egyértelmüen megállapítható, hogy a hunok hadi szerveződése is tízes rendszeren alapult. Világosan fellelhető benne a század és az ezred. A skandináv sagában a hun hadsereg legnagyobb egysége fylki néven szerepel. Az ógermán nyelvben ez a kifejezés zászlóaljat, hadrendet, harci alakulatot jelentett (RANCE 2004, 288; SPROSTON 2012). Ha figyelembe vesszük, hogy a forrás szerint ez a terminus a hunoknál a legnagyobb, az ezred után következő hadi egységet jelentette, és hogy a nomád népek seregeinek hadi szerveződésében a legnagyobb egység a tízezred, vagyis a tümen volt, akkor úgy tünik, hogy a skandináv sagában található fylki kifejezés a tízezredre vonatkozik. Ezen a forráson kívül még néhány nomád nép esetében van adatunk a tümen létszámára vonatkozólag, amelyekből kiderül, hogy csak a legritkább esetben alkothatott 10 ezer harcost egy tümen (ZIMONYI 2004, 108; ZIMONYI 2005, 89-90). ${ }^{137}$ A skandináv saga szerint a hun hadseregben egy század 160 főt, egy ezred 2080 főt, egy tízezred pedig 10400 főt foglalt magába. Az ezredeknél a saga szerzője kiemeli, hogy 1000 főnél nem lehetett kisebb a számuk (TOLKIEN 1960, 52). Ezek a számadatok azért meglepők, mert az eddig ismert, nomád népek tümenjeire vonatkozó adatok szerint nagyon ritka volt az a jelenség, hogy egy tümen ténylegesen 10 ezer harcost tartalmazott. A vizsgált forrásban pedig a század, ezred és a tízezred is nemhogy kevesebb, hanem több harcost foglalt magába. A skandináv elbeszélés szerint tehát a hun hadsereg teljes létszáma 62400 fő volt. Annak ellenére, hogy a hunok jelentős hadjáratairól,

\footnotetext{
${ }^{135}$ Wolfram és Nikonorov hívta fel a figyelmet a forrásra a hunok hadszervezete kapcsán (WOLFRAM 1990, 107, WOLFRAM 1993, 13; NiKONOROV 2002, 239; NiKONOROV 2010a, 280).

${ }^{136}$ Az egyik átirat szerint a hun hadsereg 33 fylkiböl állt, ezt azonban másolói hibaként tartják számon, és a fent nevezett adatot fogadja el a kutatás föként (TOLKIEN 1960, 52).

${ }^{137}$ A hiung-nu államszervezet kapcsán a Si-ki 11. fejezete emlékezik meg arról, hogy a 24 udvari főméltóságok 10-10 ezer lovas parancsnokai is voltak. A kínai forrás kiemeli, hogy közülük csak a legelőkelőbbek tízezrede tartalmaz ténylegesen 10 ezer harcost, a többség csak pár ezer lovassal bírt (BARFIELD 1992, 38; SzEMA-KIEN vö. Du Yaxiong-Horváth 1997, 39). A mongol korban a kínai források szerint háromféle tümen figyelhetö meg: a nagy legalább 7000 föt, a közepes, amely minimálisan 5000 föt, a kicsi pedig legalább 3000 harcost foglalt magába (ALLSEN 1987, 193).
} 
csatáiról (Mauriacum, Nedao) megemlékező latin és görög nyelvü forrásokból kikövetkeztetett számadatok (Bóna, Bachrach, Nikonorov) összecsengenek a skandináv sagával, óvatosan kell kezelni ezt a számadatot, tekintetbe véve, hogy kései forrásról van szó, és a középkori források számadatai legtöbbször inkább megbízhatatlanok, mint hitelesek. $^{138}$

\section{2. 2. 2. Katonai jeladások}

A kortárs Vegetius a katonai jeladásoknak három fajtáját különítette el: hangjeleket, félhangjeleket és némajeleket. Vegetius e terminusok közül a hangjelek alatt az emberi hangot, félhang esetében a hangszerekkel vagy egyéb tárgyakkal kiadott hangjelzést értette, valamint a hadijelvényeket, eszközöket sorolta a némajelekhez. Ezek a típusok a nomád népek esetében is megfigyelhetök.

A hangjeleket az éjszakai örségben és a harcban is alkalmazták. Erre vonatkozóan a hunoknál négy forrásban találunk utalást (AMMiANUS MARCELLINUS XXXI, 2, 8; IORDANES, Getica 212; Pseudo-Kallisthenes 264, Pseudo-Ephraem (189) 6. vö. KMOSKÓ 2004, 77, 85), az auktorok által leírt kiabálások és üvöltések esetében feltételezhető, hogy a hun egységek közötti kommunikációra is szolgálhattak.

Vegetius félhangjeleknek nevezte a trombitán, kürtön vagy harsonán kiadott jeleket (VegetiUs II. 22. vö. Várady 1963, 791-792). A hun hadsereg kürthasználatára a mauriacumi csatát megörökítő forrásokban találunk adatot, mindkét forrás tubae terminussal jelöli ezt az eszközt (IORDANES, Getica 212; PAUlus Diaconus, Historia Romana XIV. 7). Tehát a hunok esetében megfigyelhető harc közbeni kiáltásokat, hangadásokat és a kürtjeleket nem csak az ellenség megfélemlítésére alkalmazhatták, mint azt Nikonorov hangsúlyozta (NIKONOROV 2010a, 279-280). Ezek egyrészt saját „harci kedvük feltüzelésére is szolgálhattak”, másrészről pedig a hun hadseregen belüli

\footnotetext{
138 Összehasonlításképpen érdemes kitérni röviden a korszak római hadseregének létszámára vonatkozó adatokra is. Vegetius szerint kisebb háborúk esetében a rómaiak általában körülbelül 10 ezer gyalogost és 2000 lovast vetettek be. Nagyobb volumenü hadjáratokban körülbelül 20 ezer főnyi gyalogság és 4000 főnyi lovasság vett részt (VEGETIUS II. 1. vö. Várady 1963, 798-799).
} 
csapategységek közötti kommunikációra, katonai jelzések továbbítására ${ }^{139}$ is alkalmazhatták ezeket. ${ }^{140}$

Vegetius a némajelek közé a lobogókat, zászlókat, lovassági zászlócskákat ${ }^{141}$ sorolta (VEGETIUS II. 22. vö. Várady 1963, 791-792). Erre azonban a hunok esetében nincs adatunk, azonban feltételezhető a használatuk náluk is, ugyanis a nomád népek esetében széles körben elterjedtek voltak (GöCKENJAN 2004, 62-64).

\section{2. 2. 3. Pszichológiai hadviselés}

Több nomád nép esetében tetten érhető a pszichológiai hadviselés bevetése, bár a legtöbb esetben megfigyelhető, hogy az auktorok főként toposzokat használnak. A pszichológiai hadviselésnek kétféle formája tükröződik ki az írott forrásokból: egyrészt a megjelenésükkel tehették félelmetessé magukat a nomádok, másrészt csata közben adhattak ki olyan félelmetes hangokat, zajokat, melyekkel megrémíthették az ellenséget. ${ }^{142}$

Az elöbbi esetben több forrás egybehangzóan arról tudósít minket, hogy a hunok csúnyák, arcuk félelmetes, deformált, egymástól távolülő szemük és lapos orruk van, még csecsemőkorban összevagdossák az arcukat, hogy az arcszőrzetük ne nőjön ki (AMMIANUS Marcellinus XXXI, 2, 2-3; Claudianus I, 325-327; V, 270; Sidonius, Carmina II, 245-257; IORDANES, Getica 127-128). ${ }^{143}$ Ezek a forrásrészletek a hunok harcmodorára nézve semmiféle információt nem hordoznak, elsősorban a nomádokról kialakított toposzokat tükrözik, valamint azt, hogy a valószínűleg mongoloid nagyrasszhoz tartozó

\footnotetext{
139 Gardizi a besenyök esetében említ ilyen marhaszarvból készült kürtöket, melyeket harc közben szólaltattak meg. Ezenkívül még Al-Bakri is megemlékezik a besenyők kürtjéröl (GöCKENJAN-ZIMONYI 2001, 165, 222). A honfoglaló magyaroknál Ekkehard munkájából egyértelmüen kitünik, hogy a kürtöket katonai jelzésre használták (Ekkehard 3. vö. HKIF 251-252).

${ }^{140}$ Vegetius emellett a római hadsereg estében hangsúlyozza a kürtök, harsonák és trombiták hadba hívó, visszavonulást jelző, valamint csata közbeni instrukciók jelzésére szolgáló szerepét (VEGETIUS II. 22. vö. Várady 1963, 791-792).

${ }^{141}$ Ezenkívül ebben a kategóriában Vegetius megemlíti még az ostorokat is, amelyeket szerinte a barbárok használhattak. Ez alapján feltételezhetö, hogy a hunok is alkalmazhatták jelzésre ezt a tipikusan lovassági eszközt. (Bár megjegyzendő, hogy Vegetius természetesen nem csak a nomádokat sorolta a barbárok közé (VEGETIUS II. 22. vö. Várady 1963, 791-792).

${ }^{142} \mathrm{Az}$ avarok esetében találunk ilyen példát: lásd az avar fejezetben vázolt harcmodort.

${ }^{143}$ Sidonius ezek mellett még megemlítette a koponyatorzitást is (SIDONIUS, Carmina II. 245-246). A római költő által leírt szokás a régészeti anyagban is tetten érhetö, a Kárpát-medencében a 4. század végére datálható a koponyatorzítás szokásának az elterjedése, de az ezt megelőző és ezt követő időszakban is megfigyelhető. A torzított koponyák többsége azonban a 4-7. század közötti idöszakra datálható (JózSA 2006, 109).
} 
férfiak sajátosságai mennyire idegenek voltak a szerzőink számára (BóNA 1993a, 28; KISS 2005, 133-134). ${ }^{144}$

Ami ez utóbbit illeti, a hunok harci kiáltásokkal és kürtök (tubae) hangjával is próbálták megfélemlíteni az ellenséget (NIKONOROV 2010a, 279-280), erre utal Ammianus Marcellinus, Iordanes és Paulus Diaconus híradása (AMmianus MARCELLINUS XXXI, 2, 8; IORDANES, Getica 212; PAUlus DiACONUS, Historia Romana XIV. 7). Ehhez kapcsolódhat még két szír forrásban található adat, mely szerint a hunok félelmetesen üvöltenek, hangjuk az oroszlán hangjához hasonlítható (Pseudo-Kallisthenes 264, Pseudo-Ephraem (189) 6. vö. KMOSKÓ 2004, 77, 85).

Ezenkívül még a pszichológiai hadviselés egy formájának tekinthető az arra irányuló kísérlet is, hogy nagyobb létszámúnak próbálják feltüntetni a hadsereget az ellenség szemében, mint amekkora valójában. ${ }^{145}$ A hunoknál ehhez kapcsolódóan arra is találunk példát, hogy annak érdekében, hogy nagyobb létszámúnak látszódjon a hadsereg, varázslási praktikákhoz is folyamodtak. A két szír szerző örökítette meg a történetet, miszerint ez a sötét lelkü, elvetemült nomád nép szörnyü cselekedetre képes annak érdekében, hogy nagyobb létszámúnak tünjön a serege. Megfött magzat feloldódott testét vízzel összekeverték, és ebbe a folyadékba mártották fegyvereiket (kardot, íjat, nyilat, lándzsát), és ennek a folyadéknak a hatására százezer lovasnak tüntek a külső szemlélő számára: „minden száz ember őnáluk olyannak látszik, mint álló ördögök százezer tábora. ${ }^{146}$ Mert varázslataik nagyobbak az összes királyságokéinál” (Pseudo-Kallisthenes 265, vö. KMOSKÓ 2004, 77). ${ }^{147}$

\footnotetext{
${ }^{144}$ Hasonló jellemzést találunk a mongolora vonatkozóan, Plano Carpini részletesebb jellemzést ad: „,...szemük köze és arcuk szélesebb, mint másoké. Arccsontjuk erösen kiugrik állukhoz viszonyítva, orruk lapos és kicsi, szemük apró és szemkivágásuk egészen szemöldökükig emelkedik" (Plano Carpini II. 2. vö. GYÖRFFY 1965, 60). A hunok kapcsán azonban megjegyzendő, hogy a hunokhoz köthetö embertani anyag az antropológiai vizsgálatok alapján föként europid vonásokat tükröz, csak kis részük sorolható mongolidokhoz (BÓNA 1993, 28).

${ }^{145}$ Erre vonatkozóan két szír forrásban található adat felhasználásának a lehetősége is felmerülhet, miszerint minden harcost 2-3 ménes kísért (Pseudo-Kallisthenes 264, Pseudo-Ephraem (189) 6. vö. KMOsKó 2004, 77, 85). Az auktorok azonban ebben az esetben a 'ménes' kifejezést csak átvitt értelemben használták: ,,minden hun harcos egész sereg hadifoglyot hajt, mint valami ménest" (KMOSKó 2004, 77, 85).

${ }^{146}$ Pseudo-Ephraem munkájában hatezernyi sokadalom található (Pseudo-Ephraem 6. vö. KMOSKó 2004, 77, $85)$.

${ }^{147}$ Hasonló történet maradt fenn Theophanesnél a muszlimok Pergamos elleni, 716-os ostroma kapcsán (THEOPHANES 6208. vö. Turtledove 1982, 85).
} 


\section{2. 2. 4. A tábor védelme}

A nomád népek esetében több helyen találunk utalást arra, hogy a felvonuló hadsereg táborának a védelméről is gondoskodtak. ${ }^{148} \mathrm{~A}$ hunoknál a mauriacumi csata esetében figyelhető meg Iordanes munkájában, hogy Attila a hadsereg táborát szekérsánccal övezte. ${ }^{149}$ A csata második szakaszában a szorongatott helyzetükben ide vonta vissza a hunokat Attila. A támadó gót-római sereget nyílzáporral tartották távol a sánctól (IORDANES, Getica 210. vö. Kiss 2005, 83). A szekerekből összeállított, táborvédelemre szolgáló sánc nagyon gyakori jelenség a nomád népek körében, némely esetben megfigyelhető, hogy a szekerek tetejére a hatékonyság érdekében paliszádfalakat is húztak. $^{150}$

\section{2. 3. A hadsereg egységei}

$\mathrm{Az}$ írott források (és a régészeti leletek szerint is) egyértelmüen a könnyüfegyverzetü lovasság túlsúlyát és jelentőségét hangsúlyozzák. Emellett azért érdemes megvizsgálni az auktorok híradásait, hogy rendelkezhetett-e a hun hadsereg elővéddel, nehézfegyverzetü lovassággal, gyalogsággal, és alkalmazhatott-e ostromtechnikát az erödített helyek bevételekor; valamint a hun uralkodó kíséretét alkothatták-e testörök, és ha igen, akkor milyen szerepük lehetett a hun nagykirály környezetében.

A hunok, hasonlóan más nomád (és nem nomád) népek könnyüfegyverzetü lovasságához, a nyílzáporral, a színlelt megfutamodás taktikájával stb. elsősorban azt akarták elérni, hogy az ellenség egységes, zárt harcvonalát megbontsák, szétzilálják, ezáltal könnyebben legyőzhessék az ellenfelet. A hunoknál is valószínűsíthető, hogy a legtöbbször

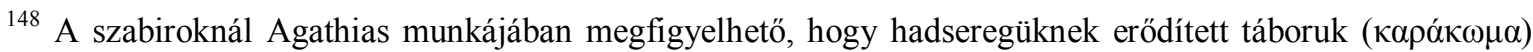
volt (AGATHIAS III. 18, 4). A muszlim források a kazárok esetében arról számolnak be, hogy a kazár harcosok mindegyike egy-egy karót vitt magával, a kiszemelt tábor helyén ezeket szorosan egymás mellé verték le, és tetejükre a pajzsukat rögzítették. Ez által egy védőfalat vontak a tábor köré (KMOSKÓ 2000, 255; GOLDEN 2002, 138). A kelet-európai nomád népek táborainak védelmével kapcsolatban lásd POLGÁR 1998, $45-53$.

${ }^{149}$ Egy még későbbi auktornál, Paulus Diaconusnál is olvasható ez a védelmi mód ugyanezen esemény kapcsán (PAUlus DiACOUNS, Historia Romana XIV. 7). Iordanes „,... castrorum, quam plaustris vallatum” kifejezéssel jelöli (IORDANES, Getica 210), Paulus Diaconus pedig a „plaustrorum munimenta” terminust használja a szekérsáncra (PAUlus DiACOUNS, Historia Romana XIV. 7).

${ }^{150}$ Már a hiung-nuknál is megfigyelhető ez a táborvédelmi mód, amikor is több kocsiból egy szekérvárat hoztak létre (KOLLAUTZ-MIYAKAWA 1970, 43). Ekkehard a honfoglaló magyarok esetében említi meg, hogy a szekereiket körben állították fel, emellett éjszaka örök is vigyázták a táborra (Ekkhard 3. vö. HKIF 251). Hasonló szekérsánc figyelhető meg a besenyőknél az 1091-es lebunioni csatában a bizánciak és a kunok ellenében (ANNA KomNENA VIII. 5. vö. Sewter 1979, 257; KovÁcs 2009, 279). A besenyök és kunok 1122es közös Bizánci Birodalom ellen irányuló támadásakor pedig paliszáddal megerösített szekérsáncot hoztak létre (KovÁCs 2012, 204). 
nem egységes, zárt hadrendbe állnak föl, hanem kisebb csapategységek egymástól függetlenül, de mégis összhangban hajtották végre a különböző taktikai utasításokat. Erre utalhat például Szent Jeromos egyik levelében vagy Ammianus Marcellinus történeti munkájában azzal, hogy a hunok ide-oda száguldozásairól, hirtelen szétszóródásairól, szétfutásairól számolnak be (HIERONYMUS LXVII. 8. vö. Adamik-Puskely-Takács 2005, 357; Ammianus Marcellinus XXXI. 2, 8. vö. Szepesy 1993, 587). ${ }^{151}$ Csak az után bonyolódtak közelharcba, hogy sikerült megbontaniuk az ellenfél hadrendjét, ekkor föként karddal és pányvával harcoltak (NIKONOROV 2002, 262; NiKONOROV 2010a, 274). Ekkor vethették be a nehézfegyverzetü lovasságukat is.

\section{2. 3. 1. Elővéd}

Más népekhez hasonlóan a nomád népek hadseregében is fontos szerepet töltött be az elővéd. ${ }^{152}$ Ennek a fösereg biztosítására elöreküldött kisebb egységnek fö feladata a fősereg megóvása az ellenség meglepetésszerü támadásától, másrészröl pedig kedvező viszonyok teremtése volt a fósereg számára. A nomád népeknél az elővéd szerepét elsősorban az alávetett segédnépek látták el, ${ }^{153}$ de szerveződhetett saját harcosaikból is. ${ }^{154}$ A hunok esetében egyetlen auktor, Iordanes utal az elővédjükre, amikor is a mauriacumi csatában egy alávetett segédnép, a gepidák csaptak össze a csatát megelőző éjjelen a római-gót szövetséges frankokkal. A forrás szerint 15 ezer frank és gepida esett el ebben az ütközetben (IORDANES, Getica 217. vö. Kiss 2005, 85). ${ }^{155}$

\footnotetext{
${ }^{151}$ Hasonlóan fogalmazza meg ezt a jelenséget például a honfoglaló magyarok harcmodora kapcsán Regino (Regino vö. HKIF 198).

${ }^{152}$ Bíborbanszületett Konstantin De adminsitrando imperio címủ munkájának egy utalásából kitünik, hogy a honfoglaló magyarok seregében a kabarok töltötték be az elővéd szerepét (KóNSTANTINOS PORPHYROGENNÉTOS 39. vö. Moravcsik 2003, 175). A mongolok esetében viszont egyértelmúen tetten érhető az elővéd, melynek a feladata a felderítés és a fősereg biztosítása volt (Plano Carpini VI. 11. vö. GYÖRFFY 1965, 80; MARCO POLO I. 54. vö. Vajda 1984).

${ }^{153}$ Például a honfoglaló magyaroknál a kabarok (KÓNSTANTINOS PORPHYROGENNÉTOS 39. vö. Moravcsik 2003, 175).

${ }^{154}$ Erre jó példát találunk Hérodotos történeti munkájában: a szkíták a területeikre benyomuló Dareios serege ellenében a legkiválóbb lovasaikból szerveztek elővédcsapatot. Ennek az egységnek az volt a feladata, hogy a perzsák elött ,járjanak”, és a felperzselt föld taktikáját alkalmazták ellenük (HÉRODOTOS IV. 121-122. vö. Muraközi 2000, 308)

${ }^{155}$ Kiss P. Attila szerint ez a gepida egység nem tekinthető a hun sereg elővédjének, ugyanis úgy véli, Iordanes azt akarta hangsúlyozni ezzel a leírással is, hogy milyen hatalmas volt a harc ebben a csatában (Kiss P. 2010a, 153).
} 


\section{2. 3. 2. Könnyüfegyverzetü lovasság}

A hunok harcmodorát általánosan jellemző források elsősorban a könnyüfegyverzetü lovasíjász jellegüket hangsúlyozták. ${ }^{156} \mathrm{Az}$ érintett auktorok munkájukban egyrészt elsősorban azokat a harcászati elemeket emelték ki, melyek ismeretlenek, idegenek voltak számukra, és ezzel párhuzamosan felhasználták a korábbi korok nomád népeiről szóló leírásokat (például Hérodotost), ${ }^{157}$ melyekből legtöbbször inkább általános, mint egyedi kép bontakozik ki a hunok hadviselésére. A korabeli szerzők antik toposzokat felhasználva többségében erősen túlzó módon jelenítik meg a hunok lovasságát (GIEßAUF 2004, 2637). ${ }^{158}$ Mint valamennyi nomád nép életének minden területén, a hunok esetében is fontos szerepet töltöttek be a lovak. ${ }^{159}$ Antik toposzokat felhasználva a kútfők hangsúlyozták, hogy ez a nomád nép állandóan a lovon ül, és minden tevékenységét a ló hátán végzi, ${ }^{160}$ valamint a hunok kiváló lovaglótudását kiemelve kentaurokként ábrázolják őket. ${ }^{161}$ Ammianus Marcellinus kiemeli a hunok nyilazásának a jelentőségét, félelmetességét (Ammianus MARCELlinUs XXXI. 2, 9. vö. Szepesy 1993, 587). Hasonló véleményen van Sidonius, aki szerint a hunok a legjobb íjászok (SIDONIUS, Carmina II. 262-265).

\footnotetext{
${ }^{156}$ A Hun Birodalom bukásához képest jóval később élt 6. századi szerző, Prokopios a bizánci seregben lévő „hun” (vagyis nomád) egységek esetében is a lovasíjász-tudásukat emelte ki (KAEGI 1990, 71).

${ }^{157}$ Például Szent Jeromos a hunokat azonosnak véli Hérodotos szkítáival (HIERONYMUS LXVII. 8. vö. Adamik-Puskely-Takács 2005, 357).

${ }^{158}$ Gießauf az íj és a ló szerepének, a lovas és a ló közötti kapcsolatának, valamint a haditaktikai elemek bemutatásával számos példán keresztül ábrázolja, hogy a kortárs források szerzői - felhasználva korábbi auktorok híradásait - hogyan jelenítették meg a számukra idegen, „primitív” nomád népek életmódban, kultúrában és a harcmodorban tetten érhető különbségeit (GIEßAUF 2004, 26-33).

${ }^{159}$ Ammianus Marcellinus és Szent Jeromos ahogy a hun harcosokat, úgy a lovaikat is eléggé negatív színben tüntetik fel. Ammianus szerint a hunok hátaslovai csúfak (AMMIANUS MARCELLINUS XXXI. 2, 6). $\mathrm{Az}$ említett auktorok bár toposzokkal élnek a hunokra vonatkozólag, ennek ellenére ebben az esetben állításuk valószínüleg megállja a helyét. Ugyanis ebben az időszakban az eurázsiai steppén általánosan elterjedtek voltak a szívós, gyors járású, alacsony marmagasságú lovak, amelyek ugyanakkor nagyfejüek, vastag és rövid lábúak, puffadt hasúak voltak (PALÁDI-KOVÁCS 1997, 101; BARTOSIEWICZ 2009, 76-78). Vegetius egyik munkájában a hunok rideg állattartására vonatkozóan találunk adatot: télen is kint legeltetik a lovaikat a szabadban. Véleménye szerint a „barbárok” lovai ennélfogva sokkal ellenállóbbak és szívósabbak, mint a rómaiak lovai. Ezek a lovak az auktor szerint nagyfejüek, kidülledt szemüek, keskeny orrlyukkal rendelkeznek, széles állkapcsuk van, a nyakuk pedig erös és merev, sörényük a térdükig ér. Úgy véli továbbá, hogy a bordáik nagyok, hátuk görbe (VEGETIUS, Mulomedicinae II. Prologus; KÁKÓCZKI 2012, 29-30; Vegetius, Mulomedicinae IV. vö. BACHRACH 1984, 11). Szent Jeromos úgy érzékeltette a római és a hun lovak közötti különbséget, hogy az előbbit equinek (ló), az utóbbit pedig caballinak (gebe) nevezte (HIERONYMUS LX. 17). A hunok lószerszámzatára lásd BÓNA 1993, 167; BÓNA et al. 1993, 22; ZASZECKAJA 1994, 40-49; KULCSÁR-ISTVÁNOVITS 2013, 1-6; KULCSÁR-ISTVÁNOVITS 2014, 269-278.

${ }^{160}$ Ammianus Marcellinus és Zosimos szerint a hunok állandóan lóháton vannak, ott is alszanak, esznek, isznak és egyéb ügyeiket is ott végzik (Ammianus Marcellinus XXXI. 2, 6-7. vö. Szepesy 1993, 587; Zosimos IV. 20, 4. vö. Rebenich 1990, 169).

${ }^{161}$ Claudianus a nubigena szót használja a hunokra (Claudianus I. 329-330), Ammianus Marcellinus pedig azt hangsúlyozza, hogy a hunok szinte oda vannak nőve a lovaikra (AMMIANUS MARCELLINUS XXXI. 2, 6. vö. Szepesy 1993, 586). Sidonius is azt emeli ki, hogy a hun lovas annyira szilárdan ült a lován, mintha együtt születtek volna (SidONIUS, Carmina II. 262-265).
} 
Olympiodoros a hun vezérek esetében a kiváló íjásztudásukat emeli ki (OLYMPIODOROS 19. vö. BLOCKLEY 1983, 182-183). Iordanes úgy véli, hogy a hunok testalkatukból kifolyólag alkalmasak az íjazásra (IORDANES, Getica 128. vö. Kiss 2005, 68). Amellett, hogy a hunok általános jellemzésénél elsősorban az íj és a nyíl használatát emelik ki a kútfők, nagyon kevés olyan forrás áll a rendelkezésünkre, mely csatajelenetek kapcsán említi meg ezt a fegyvert. Erre vonatkozó példa Iordanes történeti munkájában található, miszerint a 376-ban a hunoktól függetlenedni akaró Venetharius keleti gót uralkodót Balamber a gótok elleni hadjárata során fejbe lötte nyilával (IORDANES, Getica 249 vö. Kiss 2005, 91), valamint az Al-Duna vidéki „szkítákat” színlelt megfutamodás taktikájával győzték le (Zosimos IV. 20, 4. vö. Rebenich 1990, 169). Az írott források adataiból úgy tünik, hogy a hun könnyüfegyverzetü lovasság legyőzhetetlen lehetett, azonban néhány példa utal az ellenkezőjére is. Meglepő módon ugyanazzal a taktikai elemmel arattak teljes győzelmet a hunok felett a perzsa területek elleni hadjáratuk során a perzsa hadsereg lovasíjászai, akik hatalmas nyílzáport zúdítottak a betörő nomádokra (PRISKOS 11. 2, 607611). Egy-egy sikeres hadjáratot követően a hazafelé tartó hun sereg zsákmánnyal megrakodva nehézkessé válhatott, és hirtelen rajtaütésszerü támadással könnyen le lehetett győzni. A hunok 443-as hadjáratuk során jelentős zsákmánnyal megrakodva érték el Asemos városát, a városbeliek azonban kihasználva azt, hogy a hunok a számottevő zsákmánytól és a sok hadifogolytól nehézkessé váltak, váratlanul megtámadták őket, teljes győzelmet arattak felettük (PRISKOS 9. 3, 39-53; THOMPSON 2003, 77-78).

A források többségében megtalálhatók azok az általános toposzok a hun hadviselést illetően, melyeket a későbbi korok nomád népeire is átvettek és használtak a korabeli szerzők. Ilyen taktikai elemek az ék alakban történő támadás, a színlelt megfutamodás, a rajtaütésszerü, lesből történő támadás és a bekerítés. Ezek a taktikai elemek nagyon tipikusak és széles körben megfigyelhetők az eurázsiai steppe nomád népeit említő forrásokban (GOLDEN 2002, 135-136). Ahhoz, hogy a hunok (és más nomád népek) a taktikai elemeket eredményesen végre tudják hajtani, fontos volt, hogy a támadásaik gyorsak legyenek, és a meglepetés erejével hassanak. Iordanes írja a délorosz steppén megjelenő hunokról, hogy forgószél módjára söpörték el az ott élö népeket (Iordanes, Getica 249. vö. KISS 2005, 91). Erre utalnak Ammianus, Sidonius Appolinaris valamint Pseudo-Aurelius Victor beszámolói is (AMMIANUS MARCELlinUS XXXI. 2, 12; XXXI. 3, 1-2; Sidonius, Carmina VII. 248-250; Aurelius VICTOR, Epitomae de Caesaribus XLVII, 3). 
A hunok csatarendjére vonatkozólag kevés adat áll a rendelkezésünkre. Iordanestől a mauriacumi csata kapcsán csak annyit tudunk, hogy a római-gót sereg ellen felállt hun csapatnak volt jobb és bal szárnya, derékhada. A hunok a centrumban helyezkedtek el, míg a segédnépek az oldalszárnyakon kaptak szerepet (IORDANES, Getica 198. 199. vö. Kiss 2005, 81). Ammianus Marcellinus a hunok harcmodora kapcsán hangsúlyozza, hogy nem egységes arcvonalban állnak fel a csatában, hanem ék alakú rendben kezdték meg a harcot, több csapategységből álló, szétszóródó, laza csatarendben támadva (AMMIANUS MARCEllinus XXXI. 2, 8. vö. Szepesy 1993, 587). Ez az ék alakban történő felállás azonban nem tekinthető nomád specifikumnak, a germán nyelvü népek esetében is észlelhető a forrásokban. Ezenkívül hangsúlyozandó, hogy a nomád népek harcmodora kapcsán is kétféle kontextusban figyelhető meg. A források többsége szerint a korai időszakban a germán népek nem álltak fel egységes arcvonalban a csatákban, hanem ékekbe (cuneus) szerveződtek, és rövid ideig tartó rajtaütésszerü támadásokat intéztek, majd pedig hirtelen visszavonták a csapataikat, mielőtt az ellenségnek lett volna elég ideje az ellentámadásra. ${ }^{162}$ A germánok esetében általánosnak mondható az az álláspont, hogy ez az ékekben történő felállás a germánok vérségi, nemzetségi vagy törzsi szerveződésen alapuló hadi felállására utal (TODD 1972, 106; FERRILL 1986, 30; RANCE 2004, 292-293). A hunok mellett a nomád népek közül még az avarok esetében is megfigyelhető ez az ék alakú szerveződés. A hunok és avarok kapcsán is mindkét forrásból kitünik, hogy szétszóródó, több egységből álló, laza csatarendről van szó (MAURIKIOS XI. 2, 16. vö. SzÁdECZKY-KARdoss 1998, 83; AMMIANUS MARCELlinUs XXXI. 2, 8. vö. Szepesy 1993, 587). ${ }^{163}$ Nikonorov hívta fel a figyelmet arra, hogy az ókori forrásokban feltűnő germánok ékekbe tömörülő osztagait párhuzamba lehetne állítani a nomád népek esetében megfigyelhető hasonló formációval. Vagyis a hunok és az avarok kapcsán is a nemzetségi, törzsi alapon szerveződő hadrendi egységekről lehet szó az ékek esetében (NIKONOROV 2002, 241-242; NiKONOROV 2010a, 273-274). Tehát az ókori germán népek, a hunok és az avarok hadi szerveződésénél egy általános sztereotípiát vetítenek ki az írott források az ék

\footnotetext{
${ }^{162}$ Tacitus és Ammianus Marcellinus munkájában figyelhető meg, hogy a csatarendjük „ékekből” áll össze, ék alakú csoportokba fejlődve sorakoznak fel. Megfigyelhető, hogy rajtaütésszerü támadást intéztek az ellenféllel szemben, továbbá a cselből történő megfutamodás, majd újbóli támadás is jellemzi a harcmodorukat (TACITUS, Germania 6. vö. Borzsák 2001, 26; TACiTus, Annales 2. 45. vö. Borzsák 2001, 228; Ammianus Marcellinus XVI. 12, 20 vö. Szepesy 1993). A forrásokból azonban az is kitünik, hogy ennél sokkal összetettebb volt a germánok harcmodora már a korai időszakban is (THOMPSON 1958, 2-29). Rance is kiemeli, hogy a germán csapatok egy kisebb része fegyverzete révén képes lehetett tömör, zárt csatarendet is létrehozni (RANCE 2004, 292-293).

${ }^{163}$ Ammianus Marcellinusnál a cuneatim (AMMiAnus MarCeLlinus XXXI. 2, 8), Maurikiosnál pedig a кovv $\alpha$ (MAURIKIOS XI. 2, 16) terminus található.
} 
alakban történő felsorakozással, annyi különbséggel, hogy míg a germánoknál a gyalogságot hangsúlyozzák, addig a nomád népeknél a könnyüfegyverzetű lovasságot emelik ki. ${ }^{164}$

A könnyüfegyverzetü lovasnomádok egyik legjellegzetesebb taktikai eleme, a színlelt visszavonulás is megfigyelhető a hunok harcmodorában. ${ }^{165}$ Claudianus és Zosimos csak röviden utal a hunok ezen taktikájára: míg az előbbi szerző csak a hirtelen visszavonulást említi (CLAUDiANUS I. 331), addig az utóbbi auktor a hirtelen megfutamodás közben történő hátrafelé nyilazásról is megemlékezik (ZOSIMOS IV. 20. 4. vö. Rebenich 1990, 169). Agathias - aki ugyan csak közvetve utal a hunok e hadicselére írja le részletesebben a taktika elemeit. I. Justinianus császár Narses hadvezére 552-ben a gótok ellen vetette be ezt a - ahogy Agathias nevezi - „hun taktikát”, amely szerint a bizánciak megfutamodást színleltek, s ezzel üldözésre ösztönözték az ellenséget. A bizánci sereg a hadvezérük jelére egyszer csak megfordult, és újból támadta az üldözőit. A meglepődött sereg ellen teljes győzelmet arattak (AGATHIAS I. 22. vö. Frendo 1975, 3031). ${ }^{166}$ Némely esetben a nomád népeknél ehhez a taktikához kapcsolódik az ellenség bekerítése is, azonban ez a hunoknál nem figyelhető meg. ${ }^{167}$

\footnotetext{
${ }^{164}$ A nomád népeknél még egy másik kontextusban is feltünik az ék alakú hadrend, ami például a szarmaták és az alánok nehézfegyverzetü lovassága esetén figyelhető meg. Ezek a cataphractariusok föként a nehézfegyverzetủ gyalogság ellen voltak a leginkább hatékonyak. Jellemző rájuk, hogy szoros, zárt hadrendben álltak fel, a céljuk föként az ellenfél harcvonalának az átszakítása vagy a bekerítése volt. Fő fegyverzetük a vértezeten kívül a hosszú döfölándzsa volt. A stratégiai cél és az ellenfél sajátosságainak függvényében különféle hadrendben állhattak fel. Arrianos az alán cataphractariusoknál az ék alakzatot emelte ki. Tehát ez esetben, ellentétben a hunok és avarok ék alakú formációjával, szorosan zárt hadrenddel tudtak győzelmet elérni (HAZANOv 1968, 183; HAZANOv 1971, 78; MielCZAREK 1993, 96). Arrianos nem a

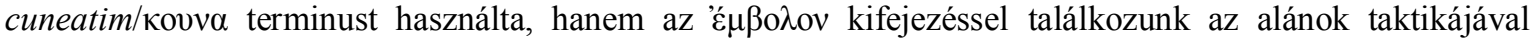
foglalkozó munkájában (ARRIANOS, Taktike 16. 6). Emellett még megjegyzendő, hogy a rómaiak harcmodorában is használták a zárt kialakítású ék alakú csatarendet (VEGETIUS 20. vö. Várady 1963, 829; AmmianUs MarCellinus XVII. 13. vö. Szepesy 1993, 148).

${ }^{165}$ A színlelt visszavonulás taktikája már a hunok megjelenését megelőzően is ismert volt. Már valószínüleg Szema-Kien is erre utalhatott azzal a két mondatával, hogy a hiung-nuk nem tartják szégyennek a megfutamodást, valamint ügyesen tudják csalétekcsapatokkal kelepcébe csalni az ellenséget (SZEMA-KIEN vö. Du Yaxiong-Horváth 1997, 19, 41). Arrianos az alánok harcmodora kapcsán tanácsolja a rómaiaknak, hogy a megfutamodó alánokat a római lovasságnak csak egy része üldözze, másik része szigorú rendben kövesse, hogy az alánok cselvetése meg ne bontsa a hadrendjüket (ARRIANOS, Ektaxis vö. ALEMANY 2000, 80). Ez a harcmodor azonban nem tekinthető specifikusan nomád harcmodornak. A vízigótok a frankok ellenében vetették be sikeresen ezt a cselt. A bizánci sereg 554-ben a frankok ellen alkalmazta ezt a taktikát, vagy az 1066-os hastingsi csatában a normannok folyamodtak ilyen hadicselhez. Bachrach mutatott rá, hogy a bizánciak és a nyugat-európai népek a steppei nomádoktól vették át ezt a harcmodort, és a 11. századra széles körben elterjedt (BACHRACH 1971, 344-347). Veszprémy László úgy véli, hogy a színlelt visszavonulás taktikájának a bizánci és nyugat-európai világban történő meghonosodásában a steppei hatások mellett az Ószövetség és annak kommentárjai (például Szent Ágoston) is jelentős hatással lehettek (VESZPRÉMY 1991, 2-5).

${ }^{166}$ Marco Polo a mongolok harcmodora kapcsán részletesen leírja ezt a taktikát: „,...Mivel nem tartják szégyennek megfutni a csatából, néha ezt is megteszik, majd miután a kivánt helyre csalogatták az ellenséget, futás közben gyorsan megfordulnak a nyeregben, és keményen nyilazni kezdenek az ellenségre, amivel nagy zürzavart keltenek ... Tehát látszólagos megfutamodás közben is éppen olyan jól harcolnak, mintha szemtöl
} 
A hun sereg könnyüfegyverzetü lovasságának közelharcára is következtethetünk néhány forrásból, melyek szerint a hunok kardot, pányvát és esetleg lándzsát használhattak. Ammianus Marcellinus munkájából kiderül, hogy a közelharcban a karddal párhuzamosan alkalmazták a pányvákat; miközben az ellenség a kardcsapásokra figyelt, hirtelen pányvát vetettek rá (AMmianus MARCELLINUS XXXI. 2, 9-10. vö. Szepesy 1993, 587). Sozomenos egyházi munkájában a hunok pányvahasználatáról egy konkrét esetet örökített meg: Theotimosra, Tomis városának püspökére akart pányvát vetni egy hun férfi, azonban amikor felemelte jobb karját, hogy a pányvát bevesse, csoda történt, és a felemelt keze megmerevedett (SozOMENOS VII, 26, 8). A forrásból a fegyver konkrét használata nem derül ki, más nomád népek esetében viszont eléggé részletes leírás is ismert a pányva használatát illetően. A hálós végű pányvák kapcsán Hérodotos emlékezik meg arról, hogy a sagartiusok az ellenséget megközelítették, és rávetették a hálóban végződő pányvájukat, majd pedig a hálóba beleakadt embert vagy lovat elhurcolták (HÉRODOTOS VII. 85. vö. Muraközi 2000, 485). Pausanias leírásából az egyszerü felépítésű lasszó használatáról kiderül, hogy a szarmaták megközelítik az ellenséget, rávetik a pányvájukat, aztán megfordítják a lovaikat, és visszavágtatnak, így rántják le az elfogott ellenséget a lovukról, és vonszolják maguk után (PAUSANIAS I. 21, 5. vö. Muraközi 2000, 34). ${ }^{168}$ Sozomenos hunokra vonatkozó forrásrészlete kapcsán Maenchen-Helfen felvetette annak a lehetőségét, hogy mivel a Theotimus elleni akció előtt a hun férfi a pajzsára támaszkodott, szerinte a „barbár” gyalogosan próbálta pányvával elfogni Tomis városának püspökét (MAENCHENHELFEN 1997, 184). Ezzel szemben Nikonorov álláspontja a meggyőzőbb, aki szerint a pányvát a nomádok lóháton használták (NIKONOROV 2010a, 269). Ez utóbbi véleményt erősíti meg Pausanias munkájában a szarmaták, illetve a Suda lexikonban a parthusok pányvahasználatának a leírása is (PAUSANIAS I. 21, 5. ford. Muraközy 2000, 34; SUDA 278).

szemben állnának az ellenséggel, mert hatalmas nyilfelhőket képesek kilőni, szembefordulva üldözőikkel, akik már azt képzelik, hogy megnyerték a csatát. Mikor a tatárok látják, hogy már sok embert és lovat elpusztitottak mérges nyilaikkal, felhagynak a futással, és teljes rendben, hangos kiáltásokkal ismét támadnak; így az ellenséget rövid idö alatt tönkre verik ... amikor az ellenség futni látja öket, és már azt képzeli, hogy megnyerte a csatát: tulajdonképpen akkor veszíti el.” (MARCO POLO I. 54. vö. Vajda 1984, 123) 167 Maurikios az avarok esetében egyértelmüen erről ír: a szétesett hadrendű sereg üldözőbe veszi a „szkítákat”, a leshelyről előtörő egységük hátba támadja őket, az üldözött csapat is hirtelen megfordul, és bekerítik az ellenfelet (MAURIKIOS II. 1, 11; IV. 2. vö. SzÁDECZKY-KARDOSS 1998, 81).

${ }^{168}$ Hasonló leírás található a Suda lexikonban a parthusokról, akikröl kiderül, hogy hadseregüknek külön

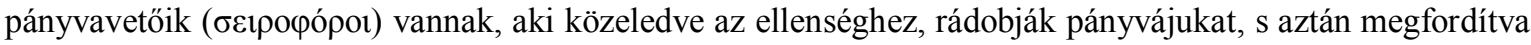
a lovaikat visszavágtatnak magukkal hurcolva a foglyaikat (SUDA 942). 


\section{2. 3. 3. Nehézfegyverzetü lovasság}

A hun hadsereg nehézfegyverzetü lovasságára vonatkozóan viszonylag kevés adatunk van. Egyrészt utalhat ezek meglétére a forrásokban néhányszor említett vértezet (PACATUS XXXIII. 4; Paulinus VI, 219-220; Sidonius, Carmina II. 253-257; VII. 289-292; Asterios 9; Merobaudes 83-84). Felmerül a kérdés ezzel kapcsolatban, hogy vajon a harcosok páncélozottsága vagy pedig a támadófegyverzetük típusa határozza-e meg elsősorban azt, hogy nehézfegyverzetű lovasról van-e szó. ${ }^{169}$ Másrészt Sidonius Apollinaris egyik költeményében maradt fenn egy összecsapás Avitus és a Litorius seregében harcoló hun között, ahol a résztvevők teljes páncélzatban (thorax) voltak. Sidonius Apollinaris leírásából úgy tünik, hogy lóháton küzdöttek egymással, összecsapásuk során döfölándzsát használtak (SIDONIUS, Carmina VII. 289-292). Maga a forrásrészlet a hun harcos esetében nem említ konkrétan fegyvertípust, csak Avitus kapcsán emlékezik meg pontosan a lándzsáról. Maenchen-Helfen úgy véli, hogy Avitusnak és a hunnak egyforma felszerelésük volt: vértezet és lándzsa (MAENCHEN-HELFEN 1997,

\footnotetext{
${ }^{169}$ Hazanov a szarmata cataphractariusok vizsgálata kapcsán jutott arra a következtetésre, hogy a harcosok harcmodorát elsősorban az határozza meg, hogy mely típusú támadófegyverzet használata mérvadó a taktikájukban (HAZANOV 1968, 180-191). Tehát a szarmata nehézfegyverzetü lovasság esetében, bár rendelkeztek íjjal, ennek ellenére a hosszú döfölándzsa használata volt a meghatározó a harcmodorukban, így nehézfegyverzetủ. Ezen elmélet alapján az ábrázolásokon látható lamellás fémvértezettel rendelkezö, de ugyanakkor íjjal harcoló mongolok nehézfegyverzetủ lovasságnak tekinthetők. Négyesi Lajos a 9-11. századi magyar sereg vizsgálata kapcsán hasonló véleményre jutott, mint Hazanov. Négyesi szerint is egy adott csapategység harcmodorának meghatározásánál az alkalmazott „harceljárás” a meghatározó, nem pedig az, hogy milyen fegyverzetet visel a harcos (NÉGYESI 2000, 375-378). Ezzel az elmélettel kapcsolatban felmerül a kérdés, hogy vértezettel rendelkező, döntően könnyüfegyverzetủ lovasságra jellemzö támadófegyverzetet alkalmazó harcos mennyire képes a könnyüfegyverzetü lovasságra jellemző gyorsaságot, mozgékonyságot, manővereket végrehajtani. Erre vonatkozóan Négyesi több átmeneti „kategóriába” sorolta Európa 9-11. századi lovasságát: helytálló lovasság, nehézlovasság, félnehézlovasság, portyázó lovasság, ijászok, szablyások. Ugyanakkor Négyesi is hangsúlyozza, hogy bár elméletben megfigyelhetők ezek az átmeneti kategóriák, addig gyakorlatban nem nagyon jellemzők (NÉGYESI 2000, 375-378). Szlanov az alánok nehézfegyverzetủ lovasságának vizsgálata kapcsán lényegében Hazanovhoz és Négyesihez hasonló véleményt fogalmazott meg. Véleménye szerint az alánok nehézfegyverzetű lovassága esetében a meghatározó, hogy mindig szorosan zárt csatarendben támadtak. Tehát Szlanov emellett megemlíti, hogy a támadó taktikája mellett nagyon ritkán, vészhelyzetben defenzív taktikát is alkalmazott az alán nehézfegyverzetủ lovasság. Ez esetben a hadrend jelentős mélységgel bírt azért, hogy a támadást vissza tudja verni (SZLANOv 2001). Ezzel szemben Hidán Csaba teljesen más véleményt fogalmazott meg ebben a kérdésben. Hidán a „keleti” és „nyugat-európai” harcmodort vetette össze. Számos példa felsorolása után alapvetően arra a véleményre jutott, hogy a nomádok esetében is megfigyelhető a páncélozottság: sisakok, sodrony- és pikkelypáncél és esetleg pajzsok használata. Ennek ellenére azonban a taktika egységesnek tekinthető a nomád népeknél: „, ... a távolsági harcot elöbbre helyezik a zárt hadrendben való közelharcnál. ... lényeg azonban a nyilazáson, a folytonos mozgáson, cselfutáson, bekeritésen volt." Nehéz egységes álláspontot kialakítani ebben a témában, mindenestre a nomád népeknél legtöbb esetben a fémvértezettel rendelkező, hosszú döfölándzsát (esetleg kétélű kardot) használó, egységes zárt hadrendben harcoló katonai egységeket sorolhatjuk a nehézfegyverzetű lovassághoz. Emellett megállapíthatjuk, hogy az erős páncélozottság lényegében összefügg az általuk alkalmazott taktikai elemekkel. Nehézvértezetben nehezen kivitelezhető a könnyüfegyverzetü lovasságra jellemző mozgékonyság, gyors, könnyed manöverezés, sokkal hatékonyabban tudtak harcolni egységes, szorosan zárt hadrendben.
} 
180-181). Tehát a hun harcos is hosszú döfölándzsával, páncéllal rendelkező nehézfegyverzetü lovas lehetett. Hazanov hangsúlyozta, hogy a hun hadsereg könnyü- és nehézfegyverzetủ egységeket egyaránt felvonultatott. Úgy vélte, hogy írott források és régészeti adatok, ha gyér számban is, de alátámasztják ezt a feltevést. A hun hadsereg nehézfegyverzetü lovasságának eredetével kapcsolatban két lehetőséget említett meg. Egyrészt utalt arra, hogy a belső-ázsiai hiung-nuknál a kínai források és a régészeti anyag alátámasztják a nehézfegyverzetű lovasság jelenlétét. Másrészről az elsőként meghódított alánoktól vehették át ezt a nehézfegyverzetü lovasságot a hunok (HAZANOV 1971, 90). Hazanov emellett azonban hangsúlyozta, hogy az esetleg keletről „hozott” nehézfegyverzetü lovasság nagyon különbözött a szarmata, alán cataphractariusoktól, nem volt akkora a jelentősége és hatékonysága (HAZANOV 1968, 189). Zaszeckaja is lehetségesnek tartja egy kis létszámú nehézfegyverzetű lovasság meglétét a hun hadseregben, de véleménye szerint a döntő szerep a harcászatukban a könnyüfegyverzetü lovasságnak jutott (ZASZECKAJA 1994, 39). A magyar kutatás is feltételez a hun vezetők környezetében - iráni mintára megjelenő - páncélos testőrséget (BÓNA et al. 1993, 16). Nikonorov ellenben teljesen más véleményt fogalmazott meg, szerinte a páncélra utaló írott források és régészeti leletek száma roppant gyér, így nem ért egyet azzal a nézettel, amely szerint a hun hadseregben lett volna nehézfegyverzetü lovasság is (NIKONOROV 2002, 293; NiKONOROV 2010a, 270). ${ }^{170}$ A külső írott források és a régészeti források hiányossága azonban nem minden esetben jelentheti azt, hogy az adott népnek ne lenne bizonyos fegyvertípusa vagy bizonyos harcmodort képviselő hadiegysége. Erre vonatkozólag jó példát szolgáltat számunkra a belső forrásokkal is rendelkezö türkök hadserege. A belső-ázsiai, török nyelvű nép esetében a kínai és a bizánci források föként a könnyűfegyverzetű lovasíjászokat hangsúlyozzák (KELLER 2004, 46-50). ${ }^{171}$ A külső írott forrásokkal párhuzamosan a türk kori régészeti anyagban ritka leletnek számít a vértezet, és a lándzsa sem jellemző a leletanyagra (MoGILNYIKOV 1981, 37; BÁLINT 1989, 254). Ezzel szemben az orhoni sírfeliratok adataiból páncélos, föként hosszú döfölándzsát használó türk harcos képe bontakozik ki (KELLER 2004, 50). ${ }^{172}$ Ezt támasztják alá a türk

${ }^{170}$ Ezzel kapcsolatban érdemes megjegyezni, hogy míg a szarmata hadseregben az írott források a cataphractariusok kapcsán kiemelik a hosszú döfölándzsa jelentőségét és szerepét, addig a régészeti anyagban ritka leletnek számít a lándzsa (HAZANOv 1971, 44; SzIMONYENKO-LOBAJ 1991, 47).

${ }^{171}$ Maurikios Stratégikon címü hadászati munkája és a Szui-su szerint fö fegyverük az íj és a nyíl volt. Emellett még mindkét forrás megemlíti a türkök lándzsáit, kardját és vértezetét is (MAURIKIOS XI. 2, 25; LIU 1958, 41).

${ }^{172}$ Köl Tegin felirat K 32, 33, 36; É 5, 6. vö. BERTA 2004, 197, 203. A külső és belső források összevetése után úgy tủnik, hogy a külső források szerzői elsősorban arról a hadiegységről emlékeztek meg, ami 
kori ábrázolások is, ahol többek között hosszú döfölándzsával ábrázolják a türk harcost (MOGILNYIKOV 1981, 126). A hun hadsereg esetében sem zárható ki teljesen, hogy a keletről jövő nomád nép hadserege magában foglalhatott kis létszámú nehézfegyverzetű lovasságra utaló elemeket is, ezeknek azonban a hatékonysága és jelentősége távol állhatott a rómaiak által jól ismert cataphractariusokétól (HAZANOV 1971, 90).

\section{2. 3. 4. Gyalogság}

Az írott forrásokból hun hadseregen belül hun gyalogságra nincs adatunk (NIKONOROV 2002, 246). ${ }^{173}$ Ammianus Marcellinus kiemeli, hogy a lábbelijük formátlansága miatt a gyalogos harcban teljesen járatlanok (AMMIANUS MARCELLINUS XXXI. 2, 6. vö. Szepesy 1993, 586). Zosimos és Szent Jeromos szerint is a hunok nem képesek gyalogosan harcolni (Zosimos IV. 20; HiERONYMUS LX. 17. vö. Adamik-Puskely-Takács 2005, 268). ${ }^{174}$

Lindner a hun hadsereg gyalogsága kapcsán arra az eredményre jutott, hogy a hunok harcmodora jelentős változáson ment át a 4. század második felétől az 5. század közepéig. Úgy vélte, hogy míg a 4. század második felében a délorosz steppén megjelenő hunok lovasnomád harcosok voltak, addig a Kárpát-medencébe beköltözve harcmodoruk átalakult. Míg a források a hunok korai időszakában kizárólag a lovas harcmodort hangsúlyozzák, addig az 5. században egyre kevesebbszer említik a hunok lovait. Lindner szerint abból kifolyólag történt ez a változás, hogy az Alföld - összehasonlítva az eurázsiai steppével - alkalmatlan volt a klasszikus lovasnomád életmód folytatására, így a hun lovasság kényszerüségből az 5. század közepére átalakult gyalogsággá (LINDNER 1981, 319; LINDNER 1982, 701-706). Nikonorov azonban több ponton is cáfolta Lindner véleményét. ${ }^{175} \mathrm{Az}$ orosz kutató elismeri, hogy Attila hadseregének szerkezeti felépítése

meghatározó lehetett a türk hadseregben és számukra idegen, ismeretlen volt. A belső források pedig a társadalom legfelsőbb rétegének (kagán, hadvezér stb.) harcmodoráról számoltak be.

${ }^{173}$ Maenchen-Helfen Sozomenos leírásából következtetett a hun gyalogságra (MAENCHEN-HELFEN 1997, 184). Nikonorov azonban egyértelműen cáfolta Maenchen-Helfen elméletét (NIKONOROV 2010a, 269). Lásd bővebben a hun fegyverzet pajzsról szóló fejezetét.

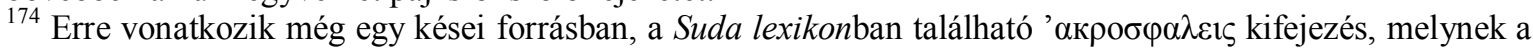
magyarázatánál a botladozó járást a hunok gyalogjárásához hasonlította (SUDA 1019).

${ }^{175}$ Nikonorov szerint elfogadhatatlan az a logikai elképzelés, hogy mivel a források nem említik a hunokat lóháton, ezért egyértelmüen gyalogos harcosok lettek volna. Emellett az orosz kutató néhány forrásrészletet is megemlít, melyek az 5. századi hun lovasság meglétét támasztják alá (IORDANES, Getica 213, 256. vö. Kiss $2005,84,93$ ). Nikonorov úgy véli, hogy a hunok európai megjelenésekor - mivel az auktorok számára idegen volt az életmódjuk, a harcmodoruk - erőteljesen hangsúlyozták lovasságukat, lovaikat a korabeli források, azonban a későbbiek folyamán ez a jelenség már megszokottá vált, és nem tartották fontosnak kiemelni. Lindner azon érvére, hogy a magyar Alföld nem volt képes eltartani a hun hadsereg nagyszámú lóállományát, Nikonorov hangsúlyozta egyrészt, hogy a hunok fennhatósága alatt álló terület nemcsak az Alföld területében merült ki, hanem a Kárpátoktól keletre eső részeket is magában foglalta. Másrészt Lindner 
jelentősen különbözött a korábbi hun hadsereg struktúrájától, melyet elsősorban a számottevő mennyiségű germán harcos beépülése okozott. Nikonorov hangsúlyozza, hogy nincs elegendő bizonyíték arra, hogy Attila hadseregének lovassága gyalogsággá alakult volna át (NiKONOROV 2002, 267-270; NiKONOROV 2010a, 278-279; NiKONOROV 2010b). Lindner véleménye tehát nem megalapozott a hun hadsereg összetétele kapcsán. A hun hadsereg forrásokból kitűnő gyalogsága elsősorban az alávetett (föként germán) segédnépek egy részéből szerveződhetett. ${ }^{176}$ Ennek ellenére fontos hangsúlyozni, hogy bár a nomád népeknél a lovasság volt a meghatározó (és az írott források ezt hangsúlyozzák), ennek ellenére néhány esetben megfigyelhető a gyalogság jelenléte is. Erre jó példát szolgáltatnak számunkra a belső-ázsiai türkök ${ }^{177}$ és a Kaukázus előterében élt szabirok. ${ }^{178}$

\section{2. 3. 5. Testőrség}

A nomád birodalmak esetében is megfigyelhető, hogy az uralkodó védelmére testőrséget szerveztek, mely a leglojálisabb és legjobb harcosokból tevődött össze. Nemcsak védte az uralkodót, hanem egyéb bizalmi feladatokat is ellátott a közvetlen környezetében. Ilyen testőrség létezett a szkíta, ${ }^{179}$ a kazár ${ }^{180}$ és a mongol uralkodó ${ }^{181}$ környezetében. A Hun

a magyar alföldi legelők eltartó képességére irányuló számításait felülbírálta. Nikonorov szerint Lindner számításainál jóval jelentősebb volt az Alföld legelőinek eltartó képessége (NIKONOROV 2002, 267-270; NiKONOROV 2010a, 278-279; NiKONOROV 2010b).

176 Emellett azonban nem szabad elfelejtenünk, hogy a germán népek esetében természetesen nemcsak gyalogsággal, hanem lovassággal is kell számolnunk (THOMPSON 1958, 5). Kiss P. Attila számos forrást sorol fel, melyek a gót hadsereg lovasságát emelik ki (KISS P. 2010a, 154).

${ }^{177}$ A türkök hadseregénél a meghatározó szerep a lovasságé volt, de emellett gyalogsággal is rendelkeztek. Erre utal a Tonjukuk felirat, amely szerint a seregük kétharmad része lovasságból, egyharmad része pedig gyalogságból tevődött össze (Tonjukuk felirat Ny 4. vö. BERTA 2004, 76). A türk gyalogság jelenlétére utalhat esetleg az a tuvai sír, melyben egy fapajzs maradványait találták: a pajzs átmérője feltehetőleg $78 \mathrm{~cm}$ volt, amit lovon nem tudtak volna használni (OBCSINIKOVA 1982, 216-217)

${ }^{178}$ A szabiroknál az írott források nehézfegyverzetü gyalogság jelenlétét támasztják alá, mégpedig kétféle kontextusban tűnik fel ez a csapategység. Agathias híradásából kitünik, hogy ezek a nehézfegyverzetü gyalogosok a nyílt csatában vettek részt (AGATHIAS III. 17, 5-6. vö. Frendo 1975, 87). Az erődített helyek bevétele során pedig a szabir nehézfegyverzetü gyalogosok a faltörő kosok munkáját segítették. A hegyes vasveretes faltörő kos jelentős károkat okozott a falakban, a folyamatos ütések hatására meglazultak a fal kövei. A falban maradt meglazult köveket ezek a páncélos gyalogosok vashorog végü rudakkal szedték ki. Másrészről pedig a védők a faltörő kosok ellen irányuló támadásait próbálták elhárítani oly módon, hogy amikor gyúlékony anyagokat hajítottak a szerkezetek tetejére, akkor megtisztították ezektől az anyagoktól a faltörö kosokat (ProKOPIOS, De bello Gothico VIII. 14, 1-14).

${ }^{179}$ A szkíta királynak fiatal harcosokból verbuvált speciális testőrsége volt, mely az uralkodó személyét védte, és speciális feladatokat látott el. Ez a testőrség föként a törzsi vezetőkből került ki (GOLDEN 2001, 156).

${ }^{180}$ A kazárok legkorábbi időszakában, a 620-as években Herakleios bizánci császár szövetségeseként a szászánidákat megtámadó kazár sereg vezetőjét egy pajzzsal és lándzsával felfegyverzett testőrség védte. Ezek a testőrök a sátort, a sátor bejáratát és a sátor udvarát őrizték. A kazárok esetében egy állandó muszlim zsoldossereggel is számolhatunk, mely 737 és 764 között jelent meg Khvárezmből a Kazár Kaganátus területén. Jogállásukat tekintve teljesen különálltak a kazár hadsereg többi részétől, erre jó példa, hogy a muszlimok elleni hadjáratokban nem kellett harcolniuk. Ennek a muszlim különítménynek két egysége volt: 
Birodalom esetében is tetten érhető az uralkodót védő testőrség jelenléte. Biztos adatunk csak Attila uralkodásának az időszakára van, Priskos fennmaradt töredékeiben található két adat, mely a hun nagykirály védelmét ellátó testőrségre utal. A forrás szerint - hasonlóan más nomád népekhez - Attila sátrát védték, másrészt pedig a hun nagykirály kíséretét

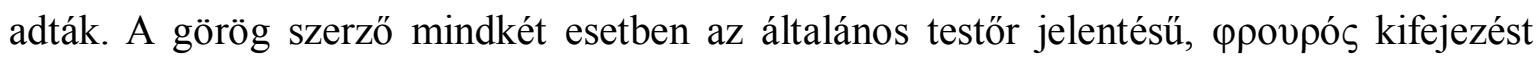
használta (PRISKOS 11. 2, 171-174; 11. 2, 566-570). Ezenkívül még egy kései szerzőnél, Malalas munkájában találunk egy bizonytalan adatot a hun uralkodó testőrségére. Az auktor Attila halálának okaként két lehetőséget is közöl történeti munkájában. Az egyik alternatíva szerint - amelynek nem tudta megnevezni a forrását - Aetius bérelte fel Attila egyik testőrét, hogy ölje meg a hun uralkodót, a testőr teljesítette a feladatot, és a történet szerint leszúrta a hun uralkodót. Az auktor a $\sigma \pi \alpha \theta \alpha ́ \rho ı \varsigma \varsigma$ terminust használta (MALALAS XIV. 10. vö. Jeffreys et al. 1986, 196). ${ }^{182}$

\section{2. 3. 6. „Müszaki”" alakulatok (ostromtechnika)}

Az erődített helyek nomád bevétele kapcsán legtöbbször a hirtelen, meglepetésszerü lerohanást, a védőket megtévesztő cselek alkalmazását, valamint az ostromzárat és az azt követő kiéheztetést hangsúlyozzák a források. Ez utóbbi esetében azonban megjegyzendő, hogy az önmagában körülzárással és kiéheztetéssel történő ostrom rendkívül időigényes volt. A Nyugat- vagy a Keletrómai Birodalom ellen vezetett hadjáratok során - különösen a birodalmi területekre mélyen behatolva - nem engedhették meg maguknak a nomád hadseregek, hogy egy-egy erődítmény ostromára huzamosabb időt fordítsanak. Másrészről ez kockázatos is volt abban az esetben, ha felmentő csapatot küldtek a város megsegítésére. A nomád népek meglepetésszerű támadása kapcsán jó példát szolgáltat a keletrómaiak egyik határerődjének hunok általi elfoglalása, amikor is vásár idején rohanták meg a támadásra egyáltalán nem számító, erődben állomásozó rómaiakat. Mint korábban

páncéllal felszerelt íjászok és lándzsás nehézfegyverzetű lovasok. Ezzel párhuzamosan viszont a kazár harcosokból verbuválódott testőrség is megfigyelhető a bizánci császár testőrségében és a kalifa katonai kíséretében is (LUDWIG 1982, 286-293; KMOSKÓ 2000, 28, 75, 171; GOLDEN 2001, 166-170; GOLDEN 2004, 279-305).

${ }^{181}$ A mongoloknál Dzsingisz kán szervezte meg a központi elit testőrséget, mely a kán biztonságáért felelt. Kezdetben még szerény létszámmal működött, azonban a 1206-tól, Dzsingisz nagykánná választása után 10 ezer harcost foglalt magába. A testőrség katonai vezetők és előkelők fiaiból, rokonaiból, valamint a közrendüek fiaiból állt. Háborúban a testőrség elit katonai egységként funkcionált, békeidőben pedig a kán védelme mellett a káni udvar gazdasági ügyeit és a káni udvar személyzetét felügyelte. A testőrségnek (kesik) három csoportja volt: az éjszakai örök (kebteül), a tegzesek (korcsi) és a nappali örök (turkak) (SHM 191192. vö. Rachewiltz 2006, 113-116; VÁSÁRY 1986, 189-190; ALLSEN 1987, 99-100).

${ }^{182}$ Erről lásd bővebben a fegyverzet fejezet vágófegyverzet alfejezetét. 
már - a felderítés szerepének kapcsán - említettem, hogy a hunok 447-es Alsó-Scythia és Moesia elleni hadjárata közben jelentős természeti csapás érte a Keletrómai Birodalmat: Thrákiát, Helléspontost és a Kykládokat hatalmas földrengés rázta meg. Konstantinápolyban a várost védő falak jelentős szakaszon leomlottak. Attila a hadjárat során ezt a helyzetet próbálta kihasználni, a hun uralkodó seregével azonban megkésett, és mire Konstantinápolyhoz ért, a rómaiak már helyreállították a falakat (BÓNA 1993a, 75; THOMPSON 2003, 81-82). Szintén a hunok kapcsán maradt fenn a csellel történő erődfoglalás is. Moesia provincia egyik erődjét, Castra Martist (Bulgária) az erődítményben lévők egyikének árulásával sikerült bevennie 408-ban Uldinnak (MAENCHEN-HELFEN 1997, 46-48, 89).

A hunok ostromtechnikájára is legtöbbször csak a hadjárataik során elfoglalt különböző erődített városok sikeres elfoglalása utal, konkrétan nem említenek ostromgépeket. A kútfőkből kiderül, hogy a Római Birodalom mindkét része ellen vezetett hadjárataik során számos erődített várost vettek be a hunok. ${ }^{183}$ Azonban csak három város - 441-ben Naissus (ma Niš, Szerbia), 451-ben Aureliana és 452-ben Aquileia - támadása kapcsán maradt ránk részletes leírás az ostromról és ostromgépeikről. Ezen három település közül a Naissus és az Aquileia elleni támadás sikeres volt, Aurelianát (ma Orléans, Franciaország) viszont nem sikerült bevenniük a hunoknak. ${ }^{184}$

A hunok történetével foglalkozó történészek többsége úgy vélte, hogy ez a nomád nép nem rendelkezett olyan hadászati tudással, amely lehetővé tette volna az erődített helyek sikeres ostromát. Ezen túl hangsúlyozzák, hogy ha használtak is a hun seregben ostromgépeket, ezeket alávetett rómaiak készítették és müködtették. Thompson Naissus ostromának a leírását nem tartotta hiteles forrásnak a hunokra vonatkozóan. Aquileia hun ostromával kapcsolatban pedig úgy vélte, hogy a hun sereg kudarca után azok az alávetett népek léptek csatasorba, akik jobban értettek az erődített települések ostromához és tudtak ostromgépeket készíteni (THOMPSON 1947, 61-65; THOMPSON 2003, 120). Blockley mind Aquileia, mind Naissus ostroma esetében feltételezte, hogy hun fennhatóság alatt álló római mérnökök készíthették el a forrásokban szereplő ostromgépeket (BLOCKLEY 1972, 18-27; BLOCKLEY 1981, 54). Hasonlóan vélekedett Maenchen-Helfen, aki Aquileia ostromával részletesebben foglalkozott, a Naissus elleni hun támadásra pedig utalt. A

\footnotetext{
${ }^{183}$ Például Arcadiopolist (ma Lüleburgaz, Törökország), Adrianopolist (ma Edirne, Törökország), Heracleiát (ma Marmaraereğlis/Ereğli, Törökország), Ratiariát (ma Arcsar, Bulgária). A hunok hadjáratára lásd THOMPSON 2003; MAENCHEN-HELFEN 1997; BÓNA 1993, 9-92; SINOR 1994, 177-205.

${ }^{184}$ Egyedül Szent Ányos legendájában figyelhető meg az a momentum, hogy mielőtt a felmentő csapatok megérkeztek volna, a hunok betörtek a városba, és feldúlták azt (VITA ANIANI 10).
} 
szerző hangsúlyozta, hogy a források által említett hadigépeket csak római hadifoglyok vagy hunokhoz szökött római szökevények készíthették (MAENCHEN-HELFEN 1997, 102, 142, 155). Bóna István Aquileia városának bevétele kapcsán nem említett ostromgépeket, Naissus esetében pedig az előbb felsorolt szerzők véleményétől kicsit eltérően úgy foglalt állást, hogy a hun sereg Ratiariában szerzett római ostromgépekkel vette be a várost (BÓNA 1993a, 54). Whitby ellenben azt emelte ki, a hunok olyannyira jártasak voltak a hadászatban, hogy képesek voltak elfoglalni jól erődített városokat is, de nem utalt konkrétan a hunok ostromtechnikájára (WHITBY 1988, 67). Golden rámutatott a hunok ostromgéphasználatára a Naissus ostromakor említett ostromgépszerü tornyok, faltörő kosok és ostromlétrák alapján (GOLDEN 2002, 151-152). Legutóbb Nikonorov foglalkozott részletesebben a hunok ostromtechnikájával, véleménye szerint ezeket a szerkezeteket a hun szolgálatban álló római hadmérnök építették (NIKONOROV 2002, 275-277; NiKONOROV 2010a, 282-283). Az Aureliana elleni 451-es sikertelen ostromot ${ }^{185}$ eddig még nem emelték ki a hunok ostromtechnikája kapcsán. A források nem szólnak arról, hogy maguk a hunok vagy a római foglyaik építették ezeket a szerkezeteket. Tekintetbe véve, hogy a Római Birodalom elleni hadjárataik esetében létkérdés volt az ostromgépek használata, feltételezhető, hogy nemcsak e három erődített település ellen vetettek be a hunok ostromgépeket. Az hadigépek használata szükséges volt ahhoz, hogy sikeresek legyenek az erődített helyekben bővelkedő területek ellen. Másrészröl a hunok ránk maradt régészeti emlékeit vizsgálva eléggé meglepő lenne, hogy ilyen jelentős ötvös- és fémmegmunkálási ismeret mellett ne tudtak volna ilyen szerkezeteket készíteni. Az ostromgépek használata a hunok esetében nem egyedi jelenség a nomád népek körében, ismert például a szabiroknál, ${ }^{186}$ az avaroknál ${ }^{187}$ és a mongoloknál ${ }^{188}$ is. A szabirok esetében

\footnotetext{
${ }^{185}$ A források többsége a hunok Aureliana sikertelen ostromáról szól (SIDONIUS, Epistula VIII. 15; IORDANES 194-195. vö. Kiss 2005, 80; GREGORIUS TURONENSIS II. 7. vö. Adamik-Mezei 2010, 189). Szent Ányos életét megörökítő munka szerint viszont mire Aetius és Theoderich seregével megérkezett a mai Orléansba, a hunok már javában fosztogattak a városban (VITA ANIANI 10).

${ }^{186}$ Prokopios a szabirok esetében nemcsak a lovasíjász harcmodorukat emelte ki, hanem egyéb hadi technikai újításukat is (KAEGI 1990, 72-73). A szabirok ezen haditechnikai újítása Petra bizánci ostrománál jelenik meg elöször Prokopiosnál. A bizánciak a hagyományos ostromszerkezeteikkel nem tudták bevenni a nehezen megközelíthető várost, és a velük szövetséges szabirok készítettek egy könnyen hordozható, nehéz terepen is kiválóan használható faltörő kost. A forrás szerint a faltörő kos keretét alkotó függőleges és keresztirányban elhelyezett gerendák helyett vastag karókat illesztettek össze. A közepére pedig lánccal függesztették fel a falak és a kapuk rombolására szolgáló gerendát, melyet vasveretü, keskeny fejjel láttak el. Az egész konstrukciót pedig befedték nyersbörrel, a szerkezetet negyven ember tudta egyszerre hordozni és müködésbe hozni (Procopios, De bello Gothico VIII. 11, 29-32). A szerkezet müködését a két oldalán álló páncélos gyalogos is elősegítette. A hegyes vasveretes faltörő kos jelentős károkat okozott a falakban, a folyamatos ütések hatására meglazultak a fal kövei. A falban maradt meglazult köveket ezek a páncélos gyalogosok vashorog végü rudakkal szedték ki. Másrészröl pedig a védőknek a faltörö kosok ellen irányuló támadásait próbálták elhárítani a páncélos gyalogosok, oly módon, hogy amikor is gyúlékony anyagokat hajítottak a szerkezetek tetejére, akkor megtisztították ezektől az anyagoktól a faltörő kosokat. Ezt az újfajta
} 
kiemelendö, hogy olyan faltörö kost tudtak készíteni, amely típus teljesen ismeretlen volt a bizánciak és a perzsák körében.

A hunok hajítógép-használatára Iordanes Priskos nyomán utal Aquileia ostroma kapcsán. ${ }^{189}$ Iordanes szerint a hunok körülzárták a várost, de hosszú ideig tartó ostrommal sem értek el eredményt. Attila már az ostromzár feloldásán gondolkodott, amikor egy „égi jelet" látott. Az Aquileiában fészkelő gólyák fiókáikkal együtt elhagyták a várost. A hunok fejedelme úgy vélte, hogy a madarak megérezték a fenyegető veszélyt, és ezért költöztek el, ennek hatására újból támadásba lendültek a hunok, és elfoglalták a várost. Iordanes az utolsó roham kapcsán említi, hogy a hunok ostromgépeket alkalmaztak, melyekkel többfajta lövedéket ki tudtak lőni. A leírásból azonban nem lehet egyértelműen

hadigéptípust Prokopios munkájának egy másik részletében is megemlíti (Prokopios, De bello Gothico VIII. 14, 1-14). A szabirok a perzsákkal szövetségben a szintén nehezen megközelíthető lazikai Archaeopolis ostromakor Mermeroes perzsa hadvezér utasítására vetették be a szabirok által készített faltörő kosok sokaságát (PROCOPIUS, De bello Gothico VIII. 14, 3-8). Prokopios a szabirok találmányára az általánosságban faltörö kosokra alkalmazott kpıó terminust használja. A szövegkörnyezetből és a szerző jellemzéséből egyértelmüen kitűnik, hogy miért jelentett újdonságot a perzsák és a bizánciak számára ez az ostromgép. A bizánciak a hagyományos, kerekeken guruló, nehéz gerendákból felépülő keretbe felfüggesztett, feji részén vaslemezzel beborított faltörő kosokat sík terepen kiválóan tudták alkalmazni. Azonban tagolt felszínủ, nehezen megközelíthető terepen használhatatlanok voltak. Prokopios leírása szerint a szabirok rendkívül könnyủ szerkezetet építettek fel, úgy, hogy a felfüggesztésre szolgáló keretet nem gerendákból, hanem vastag karókból építették fel. Olyan könnyüre építették ezt a szerkezetet, hogy negyven katona a vállán könnyedén tudta vinni a faltörö kost, és közben képesek voltak müködtetni is. Prokopios többször hangsúlyozza, annak ellenére, hogy mind a perzsák, mind a bizánciak kiváló hadászati mesterekkel rendelkeznek, teljesen ismeretlen volt számukra ez a konstrukció, és emellett jól használhatónak és hatékonynak bizonyult mindkét ostrom alkalmával. Ennek ellenére azonban úgy tünik, hogy ez a faltörökostípus nem honosodott meg a bizánci ostromtechnikában, ugyanis a 6. századi vagy ettől későbbi bizánci hadászati munkák nem említik. Sőt Maurikios Stratégikon címủ munkájában olyan ostromok esetében, amikor nehezen lehet megközelíteni az erődítmény falait, és nem lehet faltörő kost felállítani, alkalmazni, a szerző hajítógépek bevetését ajánlja. Azt azonban figyelembe kell venni a közép bizánci korszakkal kapcsolatban, hogy ezen időszakban a bizánci hadtudományi irodalom keveset foglalkozott az ostromtechnikával, Maurikios is csak röviden, általánosságban értekezik e témáról (MAURIKIOS X. 1. 55-56). A 10. századi szerző, Nikephoros Ouranos hadászati munkájában is csak megemlíti az ostromeszközök között a faltörő kososkat, de nem jellemzi azokat (NIKEPHOROS OURANOS 65, 22). Bár a források a szabirok kapcsán más ostromgéptípus készítését és használatát nem említik, azonban valószínüsíthetö, hogy ha az ostromtechnika terén képesek voltak egy teljesen új típust megtervezni és felépíteni, akkor más ostromgépeket is használhattak: például ostromtornyokat, hajítógépeket. Erre utalhat Malalas azon híradása is, hogy amikor a szabirok 515 körül betörtek Kappadokia területére, számos erődöt elfoglaltak, elpusztítottak. A szabirok ezen támadása miatt I. Anastasios bizánci császár kénytelen volt jobban megerösíteni a területen fekvő erődítmények falait (MALALAS 406. vö. Jeffreys et al. 1986, 227).

${ }^{187}$ Lásd az avar fejezet ostromgépekkel foglalkozó részét.

${ }^{188}$ A mongolok ostromtechnikáját az írott források mellett a képi ábrázolások is alátámasztják. Plano Carpini csak arról emlékezik meg, hogy a mongoloknak vannak hadigépeik, de nem említ pontos típusokat (Plano Carpini V. 15; VIII. 13. vö. GYÖRFFY 1965, 71). A képi ábrázolásokból viszont kitünik, hogy a mongolok használtak ellensúlyos hajitógépeket (HOFFMANN 2005, 252-253). Ennek a Kínában feltalált szerkezetnek a használata a 12. század végétől terjedt el (LÁszLó 1909, 779; HiLL 1973, 103).

${ }_{189}$ Priskos Aquileia hun ostromáról szóló része Iordanes mellett Prokopios munkájában is fennmaradt (BLOCKLEY 1981, 61, 115). Prokopios hasonlóan Iordaneshez megemlékezik munkájában arról, hogy a hunok kezdeti sikertelen ostroma után Attila egy égi jel (miszerint a gólyák fiaikkal együtt elhagyták az ostromlott várost) hatására újabb rohamot indított Aquileia ellen, és sikerült bevennie a várost. Prokopios részlete azonban nem nevezi meg, hogy milyen eszközöket vetettek be a hunok Aquileia ostromakor (Prokopios, De bello Vandalico III. 4, 29-36. vö. Dewing 1953, 43-45). 
következtetni a hajítógép típusára, a szerkezetet a forrás az ostromgépekre általánosan használatos machina terminussal jelöli. Csupán csak arra tér ki a szerző, hogy többfajta lövedéket löttek ki a gépezetből (IORDANES, Getica 219-224). Az ókori és a kora középkori Európában a torziós hajítógépek használata terjedt el általánosan. Ezek a szerkezetek többféle lövedéket is képesek voltak kilőni, nyílvesszőt, követ, sőt gyújtószerkezetet is [22., 23. kép] (LÁSZLÓ 1909, 779; MARSDEN 1969, 24-33; BENNETT 2001, 33, 61). A Kínában feltalált, és keletről nyugat felé elterjedt egyszerübb szerkezetű hajítógép, mely csak kövek kilövésére volt alkalmas, a Hun Birodalom időszakában azonban még nem figyelhető meg a forrásokban Kelet-Európában [24., 25. kép], ${ }^{190}$ így valószínűleg a hunok a torziós lövőszerkezetet alkalmazhatták. Ezt támasztja alá Iordanes utalása is, mely szerint ezzel a gépezettel többféle lövedéket is kilöttek (IORDANES Getica 219-224), valószínüleg nyílvesszőt, követ és gyújtószerkezetet is.

Priskos töredékesen megmaradt munkájából Naissus hun ostromáról részletesen értesülünk. A leírásból kitünik, hogy a hun hadsereg először egyszerübb ostromtornyokról lőtte a várbelieket, majd faltörő kosokat vetett be, végül pedig ostromlétrákon támadott. A forrás értékével kapcsolatban megoszlik a kutatók véleménye. Thompson vetette fel, hogy Priskos egyszerüen átvette a Kr.e. 5-4. században élő Thukydidestől Plataea (Görögország) ostromának (Kr.e. 431) a leírását, és semmilyen forrásértékkel nem bír a hunokra vonatkozóan (THOMPSON 1947, 61-65). Blockley részben elfogadta Thompson véleményét, és úgy vélte, Naissus ostromának a leírásakor Priskos követhette Thukydides nyelvezetét, és kölcsönözhetett tőle szavakat. Emellett Blockley nem tartotta kizártnak, hogy a hun seregben római mérnökök fogolyként elkészíthették ezeket az ostromeszközöket (BLOCKLEY 1972, 18-27; BLOCKLEY 1981，54). Bóna, MaenchenHelfen és Golden sem vonta kétségbe a forrásrészlet hitelét (BÓNA 1993a, 54; MAENCHENHELFEN 1997, 102, 142, 155; GOLDEN 2002, 151-152).

Valószínűleg egyszerübb felépítésű ostromtorony-szerkezetre utal a Priskos munkájában található, kerekeken gurítható gerendaállvány kifejezés ( $\mu \eta \chi \alpha v \eta \varepsilon \pi \imath \tau \rho \circ \chi \omega v$

\footnotetext{
${ }^{190}$ A Kínában feltalált egyszerübb szerkezetű hajítógép parittyájában lévő kőlövedéket a kar másik végén lelógó kötelek meghúzásával több katona tudta kilőni. Ez az eszköz a torziós szerkezeteknél nehezebb lövedékeket tudott elhajítani, bár hatótávolsága és a pontossága rosszabb volt a torziósokénál (HILL 1973, 99-100; MCСотTER). Ennek a típusnak az európai megjelenése nem egyértelmü a forrásokban. D. R. Hill szerint ez a típus csak a 7. század végén, arab közvetítéssel került Európába (HiLL 1973, 99-100). M. Bennet szerint viszont már jóval korábban, az 5. században eljutott kontinensünkre ez a szerkezet (BENNET 2001, 321). M. Whitby és S. McCotter nem tartják kizártnak, hogy az addig még Európában ismeretlen ostromgéptípus elterjedése az avarokkal hozható összefüggésbe (WHITBY 1988, 118; MCCOTTER). A Kínában feltalált másik hajítógéptípus, az ellensúllyal rendelkező szerkezet azonban csak a 12. század végétől terjedt el (LÁsZLó 1909, 779; HILL 1973, 103).
} 
$\kappa \varepsilon 1 \mu \varepsilon ́ v \eta)$, az eszközt Naissus ellen vetették be a hunok. Az ezen a szerkezeten álló hun harcosok lötték a falak védőit, és a kerekeken mozgatható konstrukciókat hun katonák mozgatták az ostrom közben, hogy azok a szerkezet tetején harcolók számára megfelelő helyen álljanak a támadás során (PRISKOS 6. 2. vö. Blockley 1983, 230-233). Az ostromtornyokon álló hun harcosok a forrás szerint $\beta \varepsilon ́ \lambda o \zeta$-al lőtték a város védőit. $\mathrm{A}$ kifejezés jelentése nem egyértelmü, vonatkozhatott nyílvesszőre, hajítódárdára és általános értelemben vett lövedékekre is. A hadászati kézikönyv szerzője, a 4. századi Vegetius szerint az ostromtornyokon az íjászok mellett dárdát és köveket dobáló katonák is harcoltak. Így a hunok esetében sem zárható ki ezek jelenléte az íjászok mellett. Az ostromtornyok egyfajta ellenerődként funkcionáltak az erődítmények fala mentén. Az ostromtornyokat általában $\pi u ́ \rho \gamma o \varsigma$ vagy $\xi v \lambda o \pi v ́ \rho \gamma o \varsigma$ néven említik a görög források. Ezek a szerkezetek általában több emelettel rendelkeztek, és minden szintnek megvolt a sajátos szerepe az ostromban (MARSDEN 1969, 188, 198). ${ }^{191}$ Priskos leírásából jól kitűnik, hogy a hunok által használt (valószínüleg egyszintes), kerekeken gurítható gerendaállványok a

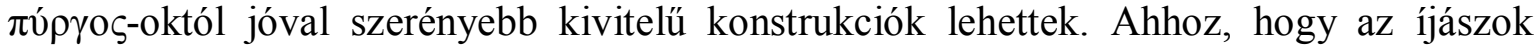
biztonságosan tudjanak löni ebből a szerkezetből, füzfavesszőből fonott palánk védte őket, melyet nyers marhabőrrel vontak be, és így az megóvta az ostromlókat nemcsak az egyszerü lövedékektől, hanem a tüzes gyújtószerkezetektől és nyilaktól is (PRISKOS 6. 2. vö. Blockley 1983, 230-233). A későbbiekben hasonló felépítésű védőtetőkről találhatók adatok Agathias munkájában, és a 6. század közepére keltezhető ismeretlen szerző hadászati művében a rómaiak ostromtechnikája kapcsán, valamint a 6 század közepén, a Kárpát-medencében megjelenő avarok esetében is megemlékeznek a források ilyen ágakból, vesszőből fonott, bőrrel bevont védőtetőkről és palánkokról. Ezek a védőtetők egyrészt az ostromgépeket óvták az erődítmény védőinek támadásaitól, másrészt önmagukban is szerepet játszottak az ostromokban. Közvetlenül a falak mentén azoknak a katonáknak biztosított védelmet, akik a falakban igyekeztek kárt tenni (AGATHIAS III. 5, 911. vö. Frendo 1975, 73; ANONYMUS XII. 30-35. vö. Dennis 1985, 34-35; MiRACULA S. DEMETRII I. (14) 139, 146, 147, 148, 150, II.2. 203, 211. vö. SZÁDECZKY-KARDOSS 1998, 115-116, 159-160; Theodóros Synkellos XVIII. 305, 13-36, XXXV. 312, 19-313, 4. vö. SZÁDECZKY-KARDOSS 1998, 186-187). Ez utóbbi védőtetőt azonban nem említik a források konkrétan a hunok esetében.

${ }^{191}$ A Kr. u. 4. század végén, 5. század elején élt szerző, Vegetius hadtudománnyal foglalkozó munkájában jellemzi részletesebben, hogy az ostromtornyok alsó részén faltörő kos működik, felsőbb részein lándzsások, ijászok, parittyások támadásával és kisebb hajítófegyverek bevetésével vették fel a harcot a városok védőivel (VEGGETIUS IV. 17, 21. vö. Várady 1963, 848, 850). 
Szintén Naissus ostroma kapcsán emlékezik meg Priskos a hunok faltörő kosairól,

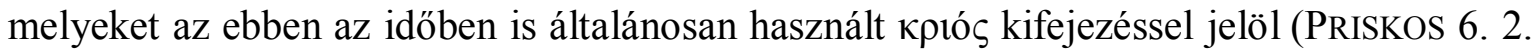
vö. Blockley 1983, 230-233). A faltörö kost laza láncok segítségével függesztették fel egy fakeretbe, melynek segítségével előre-hátra lehetett mozgathatni a célpont előtt. Priskos szerint ezek az ostromgépek hatalmas szerkezetek voltak, és a keretek segítségével a kezelöiknek nem kellett a súlyát tartaniuk, hanem csak lendületet kellett biztosítani a használatához. A faltörő kos fejrészét, mellyel a falakat rombolták, fémlemezzel vasalták meg. A szerkezet kezelőit - hasonlóan az előbb említett gerendaállványhoz - ágakból, füzfavesszőből font palánk óvta az erődítmény védőinek támadásaitól. Ezt a palánkot is nyersbörrel vonták be (PRISKOS 6. 2. vö. Blockley 1983, 230-233). Hasonló típusú faltörö szerkezetek ismertek a rómaiak és később a Kr. u. 6. század közepétől feltünő avarok haditechnikájában is. ${ }^{192}$ A leírásból kiderül, hogy a hunok ezeket az ostromeszközöket nemcsak az erőd kapui ellen, hanem föként a falak megrongálására használták (PRISKOS 6. 2. vö. Blockley 1983, 230-233).

Ezenkívül Naissus bevételekor ostromlétrákat is alkalmaztak. Priskos leírásából jól kibontakozik az ostrom menete is, amikor is az ostromtoronyszerü szerkezeteken álló ijászok folyamatos nyílzáporának hatására a falak mellvédjein harcoló védők kénytelenek voltak visszavonulni. Ekkor vetették be a hunok a nagyszámú faltörő kosukat, melyek segítségével megrongálták a falakat. E szerkezetek sikeres müködése után, az ostrom befejező szakaszában alkalmazták a megrongálódott falrészeken az ostromlétrákat (PRISKOS 6. 2. vö. Blockley 1983, 230-233).

Priskos részletes ostromleírásához képest viszonylag rövidebb leírás maradt ránk Aureliana sikertelen támadása kapcsán. Az eseményről több forrás is megemlékezik, és közülük két munkában található a hunok ostromtechnikájára vonatkozó adat. ${ }^{193}$ Szent

\footnotetext{
${ }^{192}$ Hasonló típusú faltörő kosokat használtak a rómaiak és az avarok is. Josephus Flavius Kr. u. 1. századi szerző szerint ennek a rómaiak által használt ostromgéptípusnak az alapját egy hajóárbochoz hasonló hatalmas gerenda képezte, aminek elején kosfej alakú erös vasveret volt (JOSEPHUS FLAVIUS III. 7. vö. Révay 2004, 269). Hasonlóan vélekedik a 4. század második felében élt Ammianus Marcellinus is, aki szerint ezek az ostromgépek hosszú fenyö- és kőrisfából készülnek, és az első részüket erős vasba foglalták (AMMIANUS MARCELLINUS XXIII. 4. vö. Szepesy 1993, 326). Josephus Flaviustól tudjuk azt is, hogy a faltörő kosokat és kezelöiket vesszőfonattal vették körül, és marhabörökkel vonták be a fegyver tetejét (JOSEPHUS FLAVIUS III. 7. vö. Révay 2004, 269). Az avarok faltörökos-típusát a Miracula S. Demetrii szerzöje jellemzi részletesebben, miszerint e szerkezetek fából készültek, és a fejrészük vassal volt beborítva. Az avar faltörő kosok fel voltak függesztve egy-egy keretbe, amelyböl elöre-hátra lengtek a célponttal szemben. Ezek az ostromgépek könnyen mozgathatók voltak a keretre szerelt kerekek következtében (MIRACULA S. DEMETRII I. (14) 139, 146, II.2. 203. vö. SZÁDECZKY-KARDOSS 1998, 115-116, 159-160).

${ }^{193}$ A hunok 451-es galliai hadjáratának leírásakor csak érintőlegesen emlékezik meg Aureliana ostromáról a szintén kései szerző Iordanes, és nem említi ez esetben a hunok ostromszerkezetét (IORDANES, Getica 194195. vö. Kiss 2005, 80). A gót származású szerző munkájával kapcsolatban azonban általánosan elmondható, hogy a galliai hadjárat első szakaszáról nagyon kevés információt közöl (KISS 2005, 146). Egyik levelében
} 
Ányos legendájából és Tours-i Gergely munkájából kiderül, hogy Attila Gallia elleni 451es hadjárata során Orléans ellen ostromszerkezeteket vetettek be a hunok. A két forrás ezt a szerkezetet egységesen aries terminussal jelöli (GREGORIUS TURONENSIS II. 7; VITA ANIANI 9), mely kifejezés általános, faltörő kos jelentéssel bír (FINÁLY 1884, 169; GLARE 2000, 169). A két munka közül a legenda tárgyalja részletesebben az eseményeket: az auktor szerint a hun harcosok árkot ásnak, faltörö kosokkal állandóan döngetik a falakat, lazítva ezzel a falak építőköveit, és égö lövedékeket is bevetnek (VITA ANIANI 9). Az árokásással kapcsolatban két lehetőség is felmerül. Egyrészt, ahogy az avaroknál találunk erre példát, a saját hadseregük védelme érdekében árkokat áshattak, melyekbe hegyes karókat állíthattak, végül pedig letakarhatták, hogy az ellenség ne vegye észre. Ezt a csapdát az ostromlók azért állíthatták fel, hogy az ostromeszközeiket a várbeliek esetleges kirohanásai ellen ily módon is biztosítsák (SZÁDECZKY-KARDOSS 1998, 161). A másik lehetőség az, amiről Vegetius emlékezik meg, amikor is az ostromlók árkot, vagyis inkább aknát vagy alagutat ásnak azon célból, hogy behatolhassanak a városba, illetve leomlasszák a falakat (VEGETIUS IV. 24. vö. Várady 1963, 852). Ezzel kapcsolatosan a nomád népek közül a mongoloknál találunk példát, akik Kína területén egy erődített várost ezzel technikával vettek be (Plano Carpini V. 9. vö. GYÖRFFY 1965, 71). A faltörö kosok szerkezetére, felépítésére nem találunk bővebb információt a forrásban, valószínűleg a Priskos leírásában található szerkezetűek lehettek ezek is. Az égő lövedékek típusát ${ }^{194}$ azonban nem lehet meghatározni a forrásból. Ezek lehettek dobódárdák, nyilak, és nem zárható ki az sem, hogy hajítógépekből kilőtt lövedékekről lehet szó.

\section{2. 4. Az alávetett segédnépek szerepe}

A nomád hadseregekben fontos szerepet játszottak a különböző alávetett népek. Az írott források kétféleképpen utalhatnak a segédnépek meglétére: ritkább esetben egy-egy csata vagy hadjárat leírásakor említik, hogy mely népek harcolnak még a fősereggel. A második esetben - és ez a gyakoribb - a birodalom kialakulása kapcsán említik a források, hogy az adott nép mely népeket hódított meg, illetve a birodalom felbomlása kapcsán mely népek váltak ki. A nomád hadseregekben meghatározó szerepet játszottak az alávetett segédnépek, ami előnyökkel és hátrányokkal is járt. Ezek a csapattestek töltötték be

Sidonius Appolinaris is röviden megemlékezik arról, hogy a hunok megpróbálták bevenni Aureliana városát. Azonban ő sem tér ki a hunok ostromszerkezetére (SIDONIUS, Epistula VIII. 15).

${ }^{194}$ Lásd bővebben a kérdéses fegyverterminusokról szóló fejezetet. 
általában az elővéd és az utóvéd szerepét, másrészről a harcmodor szempontjából sokszínűbbé válhatott ez által a hadsereg. Emellett azonban a segédnépek esetében számolni kellett azzal, hogy nem feltétlenül maradnak hüségesek, és ha a helyzet úgy hozza, átpártolhatnak az ellenséghez. A hunok esetében nomád, iráni nyelvü és letelepült, germán nyelvü népek alkothatták a hadsereg segédcsapatait.

\section{2. 4. 1. Alánok}

Az iráni nyelvü népek közül az alánokkal számolhatunk a hun hadseregben. A 370-es években a Volgán átkelő hunok elsőként az alán törzsszövetséget győzték le (MAENCHENHELFEN 1997, 15-16; THOMPSON 2003, 31; IORDANES, Getica 126-127. vö. Kiss 2005, 67; Ammianus Marcellinus XXXI. 3, 1. vö. Szepesy 1993, 590). Az alánok egy része csatlakozott a hunokhoz, ${ }^{195}$ és ezt követően katonai segédnépként részt vettek a hunok hadjárataiban. Bár a későbbiek folyamán a hunok hadjáratai kapcsán csak néhányszor említik meg öket a források, ennek ellenére valószínüleg a hunok több hadjáratában is részt vehettek segédnépként. ${ }^{196} \mathrm{Az}$ alánok a hun hadsereg részeként az osztrogótok meghódoltatásában játszottak először szerepet (AMMIANUS MARCELLINUS XXXI. 3, 1-3). 379-ben I. Theodosius császár (379-395) a Balkánt pusztító hun, alán és gót csapatokat győzött le. II. Valentinianus (375-392) föparancsnoka, Bauto 383/384-ben egy hunokból és alánokból álló csapatot verbuvált, akik a Raetia tartományt fosztogató juthungokat támadták meg (ALEMANy 2000, 437; THOMPSON 2003, 33, 37). 388-ban a hunok és az alánok részt vettek $\mathrm{I}$. Theodosius seregében a trónbitorló Magnus Maximus ellen vezetetett hadjáratban (PACATUS XXXIII. 4; MAENCHEN-HELFEN 1997, 180). 406-ban az alánok a hunokkal közösen a Nyugatrómai Birodalom szolgálatában tüntek fel Itáliában, és Radagais gót király (megh. 406-ban) itáliai invázióját sikeresen megállították 406-ban (Zosimos V. 26, 4. vö. Rebenich 1990, 234; THOMPSON 2003, 38). Az iráni nyelvü nomád nép hun segédnépként történő utolsó említése Iordanes munkájában található, amely

\footnotetext{
${ }^{195}$ Az alánok egy része a hunok elöl nyugat felé menekült, másik részük visszahúzódott a Kaukázus előterébe (BACHRACH 1973, 26-73; FEJÖS 2001, 7-12).

${ }^{196}$ Maenchen-Helfen úgy véli, hogy az alánokat 406 után már Gallia, Hispánia és Afrika területén említik a források, és ezzel párhuzamosan már nem figyelhetők meg a hun hadseregben (MAENCHEN-HELFEN 1997, $52-53)$.
} 
szerint a Hun Birodalom bukását jelentő nedaói csatában alánok is részt vettek (IORDANES, Getica 261. vö. Kiss 2005, 94). ${ }^{197}$

Az alánok hun hadseregen belüli szerepére Iordanes és Ammianus Marcellinus munkájából következtethetünk: Iordanes az alánok hun meghódoltatása kapcsán említi meg, hogy az alánok harcmodora a hunokéhoz hasonló, a nedaói csatában pedig nehézfegyverzetüként jellemzi őket (IORDANES, Getica 126, 261). Ammianus Marcellinus az alánok harcmodora kapcsán főként toposzokat sorol fel: a háborút és a veszélyt kedvelik, könnyüfegyverzetük van, föként lovagolnak, szégyennek tartják a gyalogjárást, a megölt ellenség lenyúzott fejbörével a lovaikat díszítik, ${ }^{198}$ valamint Iordaneshez hasonlóan ő is hangsúlyozza, hogy harcmodoruk hasonló a hunokéhoz (AMMIANUS MARCELLINUS XXXI. 2, 20-25. vö. Szepesy 1993, 589-591). Ha a hun támadás elötti alán harcmodorra vonatkozó forrásokat megvizsgáljuk, akkor Ammianus jellemzésével szemben teljesen más kép bontakozik ki az alánokról, ugyanis a könnyü- és nehézfegyverzetü lovasság is jelen volt harcászatukban. Az alán könnyüfegyverzetü lovasság ábrázolásánál hasonló sztereotípiákat találunk, mint más nomád népeknél: nagyon mozgékony, könnyen manőverezhető lovasság, mely hatalmas nyílzáport zúdít az ellenségre. Megfigyelhető náluk is a színlelt megfutamodás taktikája. A Kr. u. 1. századtól a nehézfegyverzetü lovasság is része a harcászatuknak, mely esetben a legföbb fegyverzetük a hosszú döfölándzsa és a harcosok vértezete. Emellett még használhattak íjat, nyilat és kardot is. Jellemző rájuk, hogy mindig szorosan zárt hadrendben rohamoztak, meghatározott taktikai céllal (föként áttörés, ritkább esetben bekerítés). A támadásuk történhetett egységes egyenes arcvonalban, de föként az ék alakú csatarendet alkalmazták (ARRIANOS, Ektaxis 26, 31. Taktike 4, 3; 4, 7. vö. AlEMANY 2000, 80-81; BoswORTH 1977, 234-247; SzLANOV 2000). ${ }^{199}$ A szarmata és alán cataphractariusok különösen az addig szinte legyőzhetetlen római nehézfegyverzetű gyalogság ellen voltak nagyon hatékonyak (HAZANOV 1968, 183). Hazanov feltételezte, hogy az alánok legyőzésével a hun hadseregen belül számolhatunk az alán cataphractariusok megjelenésével (HAZANOV 1971, 90). Ez azért is jelentős, mert az alánok részvételével a római gyalogsággal szemben jobban fel tudott lépni a hun sereg.

\footnotetext{
${ }^{197}$ Bóna István az Attila által 447-ben a Keletrómai Birodalom ellen vezetett hadjárat kapcsán utalt iráni nyelvü harcosokra (BÓNA 1993, 77), ezek azonban lehettek alföldi szarmaták is. Emellett Altheim feltételezte, hogy a mauriacumi csatában a hunok oldalán is harcoltak az alánok (ALTHEIM 1962, 319).

198 Hérodotos is hasonló dolgot jegyzett fel a szkítákról, az ellenség fejbőréből készült kendőt a lovuk kantárszárára akasztották (HÉRODOTOS IV. 64. vö. Muraközi 2000, 287).

199 Nikonorov a cataphractariusokra és clibanariusokra vonatkozó írott források tüzetesebb vizsgálata kapcsán felhívta a figyelmet, hogy míg az örmények, kaukázusi albánok és a szászánida perzsák nehézfegyverzetü lovasságát egyértelmüen alátámasztják az auktorok híradásai, addig a szarmaták (roxolánok, alánok) páncélos lovasságára csak két forrás utal (NIKONOROV 1998, 131-132).
} 
Tehát az alánok hun seregbe történő betagozódásával gyarapodott a hunok könnyüfegyverzetü lovassága. Emellett feltételezhető, hogy nehézfegyverzetű lovassággal, a cataphractariusokkal is bővült a hunok hadi repertoárja. Esetleg erre utalhat Iordanes nehézfegyverzetủ alán kifejezése is.

\section{2. 4. 2. Germán népek}

A hun hadseregben az alánokhoz képest sokkal nagyobb jelentőségük volt a germán nyelvü népeknek. Már a 370/380-as évektől az 5. század elejéig terjedő időszakban megfigyelhetők a germánok a hun seregben, ekkor azonban valószínüleg még nem lehetett túlzottan komoly a súlyuk. Az 5. század elejétől azonban jelentősebb számú germán segédnéppel kell számolnunk a hun hadseregben (NIKONOROV 2010a, 278-279). ${ }^{200}$

A hunok alán segédnépükkel a germán nyelvü népek közül elsőként az osztrogótokat hódoltatták meg (AMMIANUS MARCELLINUS XXXI. 3, 1-3; IORDANES, Getica 129-130). Valószínüleg szintén a 370-es években kerültek a szkírek is hun fennhatóság alá. Zosimos tudósít minket a hunok, szkírek és a karpok 381-es, a Duna menti provinciák elleni hadjáratáról (ZosIMOS IV. 34, 6. vö. Rebenich 1990, 183, 346; Kiss P. 2010a, 142-143). A Keletrómai Birodalom ellen 408-ban vezetett hun hadjáratban szintén részt vettek a szkírek abban a seregben, amelyre a rómaiak jelentős csapást mértek (Sozomenos IX. 5; Thompson 2003, 35; Kiss P. 2010a, 145). A 400-as évek elején a szvébek és a gepidák is hun fennhatóság alá kerültek, Iordanes szerint az osztrogótok vezettek hadjáratot a szvébek és a gepidák ellenében (IORDANES, Getica 250. vö. Kiss 2005, 92; Kiss P. 2010a, 143). ${ }^{201}$ Az osztrogótok, szkírek, szvébek és a gepidák mellett a rugiak jelenléte is feltételezhető a hunok segédnépeként az írott forrásokban. Valószínüleg 441-ben ${ }^{202}$ egy Valips nevü rugi (a forrásban Pov́ßouৎ) hadvezér elfoglalta Noviodunumot, és feldúlta Thrákia és Illyricum területét (PRISKOS 5. vö. Blockley 1983, 228-229, 380; KISS P. 2010a, 142-143). A Keletrómai Birodalom ellen 447-ben vezetett hadjáratban is részt vettek germánok: Iordanes megemlíti, hogy Valamer, az osztrogótok királya és a gepidák királya, Ardarich is ott volt ebben a hadi vállalkozásban (IORDANES, Romana 331;

\footnotetext{
${ }^{200}$ Kiss P. Attila úgy véli, hogy ezt a különbséget a hunokra vonatkozó források időbeli eloszlása okozza. Ugyanis az írott források többsége csak Attila uralkodásának az időszakát örökítette meg, a korábbi időszakról csak kevesebb auktor és rövidebben emlékezett meg (KISS P. 2010a, 137).

${ }^{201}$ A gót származású szerző híradásával kapcsolatban felmerül annak a lehetősége is, hogy Iordanes egy belső gót konfliktust akart azzal elkendőzni, hogy a gepidákat emelte be ebbe a szövegbe (WoLFRAM 1990, 250-258; NAGY et al. 2000, 180).

${ }^{202}$ Az esemény datálásával kapcsolatos problémákat lásd bővebben Kiss P. 2010a, 147-148.
} 
KISS P. 2010a, 147). Emellett még számolhatunk a herulok jelenlétével a hunok segédnépeként, róluk azonban csak a nedaói csatában emlékezik meg Iordanes (IORDANES, Getica 261. vö. Kiss 2005, 94). Attila 451-es galliai hadjáratában a Hun Birodalom szinte valamennyi népe részt vehetett. A Iordanes által említett gepidák és osztrogótok mellett a kutatóknak megoszlik a véleménye arról, hogy még mely népek harcoltak a hunok oldalán. Altheim szerint a germán népek közül a szkírek, a rugiak és a thüringek biztosan ott voltak. Valószínüsíti, hogy a frankok hunbarát része is jelen volt, a Rajna jobb partján élö burgundok részvételét pedig kétségesnek tartja (ALTHEIM 1962, 319). Bóna a rugiak, a szkírek, a szvébek, az alemannok és a herulok részvételét valószínüsíti, valamint a burgundok és a frankok hunbarát részeit említi még meg (BóNA 1993a, 83). Schreiber szerint a rugiak, herulok, quadok, thüringek voltak Attila seregében, és a ripuári frankok később csatlakoztak a hunokhoz. A burgundok szerinte a vízigótok és a rómaiak oldalán álltak (SCHREIBER 1976, 222). Thompson úgy gondolja, hogy a rugiak, szkírek, thüringiaiak biztosan részt vehettek a hadjáratban Attila oldalán, ezenkívül még feltételezi a ripuári frankok jelenlétét (THOMPSON 2003, 114). Legutóbb Kiss P. Attila foglalkozott a hunok germán nyelvü segédnépeivel, aki úgy véli, hogy a galliai hadjáratban a rugiak, a szkírek, a burgundok keleti része, a thüringek és a rajnai frankok jelentősebb része vállalhatott szerepet hun oldalon (KISS P. 2010a, 148-152).

A germán nyelvü népek hun hadseregben betöltött szerepéröl nagyon kevés információt szolgáltatnak a források. A germán népek harcmodorára föként a hun kor előtti és utáni adataink vannak. Kivétel ez alól egy ebből a szempontból kevés forrásértékkel bíró szerzőnk, Iordanes, aki a nedaói csatában részt vevő népek felsorolásakor utal a szerinte rájuk jellemző fegyverzetre, harcmodorra. A kései szerző a gótok esetében a lándzsát, a gepidák esetében a kardot emeli ki, és úgy véli, hogy a szvébek íjat használó gyalogosok, a herulok pedig könnyüfegyverzetü harcosok (IORDANES, Getica 261. vö. Kiss 2005, 94). Az 5-6. századnál korábbi források szerint a germán népekre főként a gyalogos harcmodor a jellemző, a meghatározó, emellett azonban megfigyelhető a lovasság is. ${ }^{203}$ Ez utóbbi

\footnotetext{
${ }^{203}$ Tacitus a germán népek általános jellemzésekor a gyalogság szerepét emelte ki, a lovasságukat is megemlítette, de szerinte ez kevésbé volt jelentős. A chatusoknál ellenben a gyalogság jelentőségét hangsúlyozta (TACITUS, Germania 6, 30. vö. Borzsák 2001, 26, 32). Caesar szerint a nerviusok harcmodorában a gyalogságnak volt a legnagyobb szerepe, úgy vélte, hogy ütőképes lovassággal nem rendelkezett ez a nép (CASESAR II. 17. vö. Szepesy 1994, 37). Tacitus emellett hangsúlyozta, hogy a germánoknál a lovasság és a gyalogság „,vegyesen” áll fel a hadrendbe (TACITUS, Germania 6. vö. Borzsák 2001, 26). Hasonló jelenségröl számol be Ammianus Marcellinus az alemannok esetében, amiből kitünik, hogy egy-egy szárnyon a lovasok közé könnyüfegyverzetü gyalogságot is elhelyeztek (AMMIANUS MARCELlinUS XVI. 12, 34. vö. Szepesy 1993, 109). Caesar galliai háborúkról szóló müvében is ezt a hadi felállást erősíti meg a germánok esetében (CASESAR I. 48. vö. Szepesy 1994, 27).
} 
azonban főként az adott közösség előkelő rétegéből került ki, és kisebb számú lehetett a gyalogságnál. Ez a lovasság azonban úgy tünik, hogy semmivel sem volt kevésbé hatékonyabb, mint a gyalogság. ${ }^{204}$ A római hadseregben előszeretettel vetették be a germán lovasságot is (THOMPSON 1958, 5-6). A 6. századra azonban sokkal összetettebbé vált a germán népek többségének hadi repertoárja. Megnőtt a lovasság szerepe a hadseregükben, megfigyelhető a könnyü- és nehézfegyverzetü lovasság is, valamint a gyalogságon belül az íjászok jelenléte is hatványozottabban tetten érhető. ${ }^{205}$ A lovasság jelentőségének megnövekedésében valószínüleg szerepet játszottak délorosz steppei nomád népek (szarmaták, alánok, hunok) is (DARKÓ 1935, 462-464; THOMPSON 1958, 8; SCHÄFER 2004, 20-25; Kiss P. 2010a, 154). Ugyanakkor erre egyértelmü adatunk csak az osztrogótok esetében van. Ezenkívül számos adat olvasható meg az írott forrásokban a germán népek ostromai kapcsán használt eszközökről (ostromtornyok, hajítógépek stb.) is (THOMPSON 1958, 13-17). A hun hadseregben jelen lévő germán népek esetében a gyalogság mellett még esetleg feltételezhetjük a nehéz- és könnyüfegyverzetü lovasságot is, valamint a germán segédnépek a hun hadjáratok során az erődített települések bevételében is aktívan részt vehettek.

Az alávetett segédnépek és a hun uralkodók közötti kapcsolatra vonatkozólag csak Attila időszakára vannak biztos adataink. A legújabb vélemények szerint maga a Hun Birodalom a különböző népek és törzsek laza szövetségének tekinthető, ${ }^{206}$ és ez a vezetőréteg személyes kapcsolatain alapult. Az alávetett segédnépeknek elsősorban katonai kötelezettségeik voltak. Az Attila uralkodásának időszakára vonatkozó kútfökben találunk adatokat az alávetett segédnépek vezetőinek a szerepére. Ezek a „fejedelmek” saját népükből kerültek ki, és saját népüket irányították, szorosan kötődtek a nagykirályhoz, Attila közvetlen környezetéhez tartoztak. A hun uralkodó haditanácsába a hun elökelökön kívül az alávetett segédnépek királyai is beletartoztak. Ilyen vezető volt az osztrogótok királya, Valamer és a gepidák királya, Ardarich (SCHÄFER 1998; SCHÄFER 2001a, 25; SCHÄFER 2001b, 27).

\footnotetext{
204 Aurelius Viktor az alemannok harcmodora kapcsán kiemeli, hogy nagyszerüen harcolnak lóháton (Aurelius VICTOR, De Caesaribus XXI. 2). Tacitus szerint a tencterek nagyon jó lovasok, és harcmodorukban is a lovasság szerepe a mérvadó (TACITUS, Germania 32. vö. Borzsák 2001, 33).

${ }^{205}$ Erre vonatkozólag főként az osztrogótoknál vannak adataink. Prokopios munkájából kiderül, hogy az osztrogótoknak volt lándzsát, vértezetet és kardot használó nehézfegyverzetű lovasságuk, emellett rendelkeztek vértezetet nem használó lovasíjászokkal, valamint gyalogos íjászokkal is. Az osztrogótok harcmodorára vonatkozólag további forrásokat lásd KISS P. 2010a, 154; NIKONOROV 2010c, 38-49.

${ }^{206}$ Attila központosított, despotikus hatalmi berendezkedésére lásd THOMPSON 2003; HARMATTA 1951.
} 


\section{2. 5. Csatajelenetek Mauriacumnál}

Az Attila 451-es galliai hadjáratának végső állomásán zajlott csata eseményeiről viszonylag részletes információink vannak. Fő forrásunk a mauriacumi csatáról az eseményt 100 évvel később megörökítő Iordanes. Emellett még néhány krónikában található viszonylag kevés adat a csatáról. ${ }^{207}$ Iordanes szerint - aki Priskos munkáját használta fel - Geiserich vandál király próbálta felbújtani Attilát a vízigótok elleni háborúra (PRISKOS 20, 2; IORDANES, Getica 184. vö. Kiss 2005, 78-79). Attila a galliai hadjárat előtt diplomáciai tárgyalásokat kezdett a rómaiakkal és vizigótokkal abból a célból, hogy megossza, és egymás ellen fordítsa a két ellenfelét (IORDANES, Getica 185186. vö. Kiss 2005, 79). Iordanes munkája alapján két részre osztható a mauriacumi csata. Az első szakaszban a két sereg egy dombnál találkozott, és a domb két oldalán táboroztak le. Mindkét csapat célja a stratégiailag fontos domb elfoglalása volt. A gót származású szerző utal a két sereg csatarendjére is. A római és gót szövetséges seregben a jobb szárnyat a vizigótok alkották Theoderich vezetésével, a bal szárnyon lévő rómaiakat pedig Aetius irányította. A két sereg között pedig a megbízhatatlan Sangibanus vezetésével az alánok helyezkedtek el (IORDANES, Getica 197. vö. Kiss 2005, 81). A hunok hadrendjéröl sokkal kevesebb információt közöl, pusztán annyi tájékoztatást kapunk Iordanestől, hogy a sereg centrumát hun harcosok alkották Attila vezetése alatt, az oldalszárnyakon pedig az alávetett segédnépek csapatai helyezkedtek el. A segédnépek közül azonban név szerint csak a gótokat és a gepidákat említi a szerző. ${ }^{208}$ A csata első szakaszában a római-gót szövetséges sereg került ki győztesen, Aetius és Thorismud vezetésével a hunokat megelőzve jutottak fel a domb tetejére. A domb oldalán felfelé igyekvő hun sereg a tetőről lezúduló római-gót hadsereggel szemben vesztes pozícióba került (IORDANES, Getica 198201. vö. Kiss 2005, 81-82). A csata két szakasza között ismerteti a gót származású szerző Attila beszédét, melyben seregét buzdította, lelkesítette (IORDANES, Getica 202-206. vö. Kiss 2005, 82-83). A csata második része rögtön Attila beszéde után következett, és a szerző eléggé realisztikusan ábrázolva rettenetes test-test elleni küzdelemről, öldöklésről számolt be. A csata közben maga a gót király, Theoderich is lezuhant a lováról és

\footnotetext{
${ }^{207}$ Például Aquitániai Prosper, Hydatius, Chronica Gallica, Sidonius Appolinaris. Täckholm szerint ezeknek a kortárs forrásoknak gyér adatai jó forrásértékủek, viszonylag objektívan emlékeznek meg az eseményekről, ami Iordanes esetében nem mondható el. A szerző úgy véli, hogy Iordanes túlzottan gót szemszögből interpretálja az eseményeket (TÄCKHOLM 1969, 259-265). Barnish ezzel szemben pont ellentétes véleményt fogalmazott meg, bár elismeri Iordanes gótokkal szembeni elfogultságát, szerinte a mauriacumi csata esetében a legteljesebb képet tőle kapjuk (BARNISH 1992, 45-47).

${ }^{208}$ Az ezzel kapcsolatos véleményeket lásd a segédnépek germánokkal foglalkozó fejezeténél.
} 
meghalt. ${ }^{209}$ Majd a vizigótok - különválva a többi egységtől - sikeres támadást intéztek a hunok ellen. Attila kénytelen volt visszavonni csapatait a szekerekkel körbesáncolt táborába (IORDANES, Getica 207-210. vö. Kiss 2005, 83). A rómaiak és gótok úgy döntöttek, hogy blokád alá helyezik a hunok szekérsánccal körbefogott táborát, magát a tábort azonban nem tudták megközelíteni a hunok nyílzápora miatt. Iordanes szerint a hunok sáncon belül harsonákat fújtak, hangoskodtak, ${ }^{210}$ valamint Attila nyergekből hatalmas máglyát rakatott abból a célból, ${ }^{211}$ hogy tűzbe vesse magát, ha a római-gót csapatok betörnek a szekértáborba. Theoderich fia, Thorismud meg akarta bosszulni apja halálát, és tovább szerette volna folytatni a hunokkal a harcot, azonban Aetius meggyőzte, hogy hagyják el a csatateret. Iordanes szerint a római hadvezér attól tartott, hogy a hunok legyőzése után a vizigótok fognak legalább akkora veszélyt jelenteni a Római Birodalomra, mint a hunok. A rómaiak és a gótok elvonulása után Attila még továbbra is a szekértáborban maradt addig, míg meggyőződött arról, hogy az ellenfél biztosan elvonult (IORDANES, Getica 213-219. vö. Kiss 2005, 84-85). Iordanes munkájának a kortárs krónikák adataival történő összevetését követően Täckholm hangsúlyozta, hogy a gót származású szerző, nem véletlenül, túlzottan kiemelte a gótok szerepét a mauriacumi csatában rómaiak ellenében. A kortárs krónikák szerint ugyanis a gótok és a rómaiak részvétele a csatában egyforma jelentőségü volt. Hasonló elfogultság mutatkozik meg a két sereg vezetőinek (Theoderich és Aetius) ábrázolásakor is Iordanesnél. Täckholm szerint ugyanez a gótok iránti részrehajlás figyelhető meg a hun sereg jellemzésekor is, Attila seregének a csatarendje kapcsán főként az osztrogótokat emeli ki, az ö vitézségüket, rátermettségüket hangsúlyozza, a hadrendről azonban nagyon kevés információt közöl. A csata későbbi szakaszában is a vizigótok szerepe a domináns Iordanes interpretálásában (TÄCKHOLM 1969, 259-268). Emellett ellentmondás figyelhető meg a két sereg hadrendje felosztásának a megítélésében is. A római-gót szövetséges hadseregnél azzal indokolja a szerző Sangibanus és csapatának a hadrend közepére helyezését, hogy meg ne tudjon

\footnotetext{
${ }^{209}$ Schreiber elképzelhetőnek tartja, hogy a vizigót király a menekülőket próbálta megállítani, vagy a lovasegységeket próbálta irányítani, és közben sodorták el lovával Theoderichet (SCHREIBER 1976, 255-256)

${ }^{210}$ Erre vonatkozóan lásd a hun harcmodor fejezet katonai jeladásokkal és a pszichológiai hadviseléssel foglalkozó részét.

${ }^{211}$ A történettel kapcsolatban felmerült annak a lehetősége is, hogy a nyergekből rakott máglya jelensége nomád hagyományokra vezethető vissza. Legutóbb Keszi Tamás vetette fel, hogy itt egy ókori reminiszcenciáról lehet szó. Az epizódot Iordanes nagy valószínúséggel Cassiodorus elveszett gót történeti munkájából vehette. A hun máglyarakás legjobb párhuzamának az utolsó asszír király, Sardanapallos története tekinthető, aki a görög hagyomány szerint a palotája berendezéseiből készült máglyába vetette magát azért, nehogy ellenségei elfogják. Ez a történet gyakorlatilag tovább élt görög és latin szerzők müveiben az 5. századig. Cassiodorus, Iordanes forrása is ismerte ezt az epizódot, így Keszi feltételezi, hogy a gót származású szerző Sardanapallos történetét vette át, és alakította át az Attilához kapcsolódó eseményekben (KESZI 2001, 63-64).
} 
futamodni a csata során. A hun sereg felállásában pedig úgy véli, hogy Attila és katonái azért helyezkedtek el a centrumban, hogy veszély esetén el tudjanak menekülni. Az előbbi csapatfelállási taktikára jó példát találunk a 1091-es lebunioni csatában, ahol a bizánciakkal szövetséges megbízhatatlannak tartott kunok a csatarendben bizánci egységekkel körülfogva állottak fel, viszont fontos hangsúlyozni, hogy a kunokat nem a derékhadban állították fel (KovÁCs 2009, 278-279). Iordanes a hun hadsereg hadrendjével kapcsolatosan valószínüleg Attila személyét próbálta kisebbíteni a gótok ellenében azzal, hogy a hun uralkodó tartott a csata kimenetelétöl, erre a történetíró más helyen is utalt (IORDANES, Getica 195. vö. Kiss 2005, 80). A csatarendben a sereg vezetöje legtöbbször középen helyezkedett el, egyrészt innen gyorsabban tudta az utasításait kiadni mindkét csapatszárnynak, másrészt a derékhadban volt a legnagyobb biztonságban. A csata kellős közepén elhangzott Attila-beszéddel kapcsolatban a kutatók véleménye többnyire megegyezik: ezt a beszédet csak Iordanes alkotta, valós alapja nincs. ${ }^{212}$ Az auktornak nem voltak kellő információi az ütközetről, jelzi ezt az is, hogy a legtöbb esetben a harc leírásakor olyan általános frázisokat alkalmaz (patakokban ömlő vér, rettenetes, fordulatos csata stb.), mely retorikai elemeket bármely más csaták esetében is be lehetne helyettesíteni. Iordanes ezekkel a közhelyekkel egészítette ki hiányos értesüléseit (TÄCKHOLM 1969, 267-268; SCHREIBER 1976, 251-252).

\section{3. Összegzés}

A hunok fegyverzetét említő források müfaja kapcsán fontos hangsúlyozni, hogy ezek a terminusok történeti munkákban és költeményekben, dicsőítő beszédekben maradtak főként fenn. Elsősorban arról adnak információt, milyen fegyvereket használhattak a hunok, de az egyes fegyvereken belüli típusokra nem következtethetünk belölük. A fegyvereket említő kortárs források közül kiemelendők Szent Jeromos levelei, melyek ennek ellenére azonban semmilyen forrásértékkel nem bírnak a hunok fegyverzetére vonatkozóan. A hunokat szinte kizárólag olyan kontextusba helyezve említi meg, amikor a rómaiak kulturáltságát, müveltségét állították szembe a primitív hunokkal. Szintén

\footnotetext{
${ }^{212}$ Nem valószínủ, hogy a csata hevében lett volna lehetőség szónoklatot tartani. Míg Attila beszélt volna, addig a rómaiak és a gótok elfoglalják az egész dombot. Másrészröl a beszédből kirajzolódó hun uralkodó jelleme egyáltalán nem feleltethető meg a Priskostól származó Attila-képnek, aki lobbanékonynak és szükszavúnak ábrázolja a hun nagykirályt. Nyilvánvalóan Iordanesnek nem voltak kellő információi a csata menetéröl, és így próbálta kitölteni a számára hiányos eseménysort (TÄCKHOLM 1969, 267-268; SCHREIBER 1976, 251-252). Täckholm és Barnish emellett azonban elképzelhetőnek tartja, hogy ez a beszéd Cassiodorustól származik, és eredetileg a csata kezdete előtt hangzott el (TÄCKHOLM 1969, 268; BARNISH 1992, 40).
} 
rendkívül sok toposzt, sztereotípiát tartalmaz Ammianus Marcellinus munkája, aki csak hallomásból ismerte a hunokat, és ez a szerző is többnyire rendkívül negatív színben tünteti fel e nomád nép szokásait, kultúráját. Ennek ellenére találhatók a történeti munkájában olyan adatok, melyeket más források is alátámasztanak a fegyverekkel kapcsolatban. Erre jól példa a pányva használata. Bár Sidonius Appolinaris költeményeiben is több toposz figyelhető meg a hunokra vonatkozóan, ennek ellenére néhány értékes adatot is közöl különböző fegyvertípusokkal kapcsolatban, melyeket más források is alátámasztanak. Erre jó példa az íj rövid jellemzése, melyböl kitünik, hogy ezek az eszközök, szép, míves darabok voltak. Az egyik költeményében pedig egy csatajelenet maradt fenn, melyböl következtethetünk a hunok törzspáncéljára is. Annak ellenére, hogy a kortárs Pacatus, Asterios és Merobaudes is költeményben/dicsőítő beszédben örökítették meg a hunok fegyverzetét, mégis fontos információkat tartalmaznak a védő- és támadófegyverzetükről. Pacatus leírásából értesülünk a hunok vértezetéről, mégpedig saját készítésủ darabokról. A két utóbbi szerző híradásaiból pedig a hunok fegyverzetének díszítésére következtethetünk, miszerint arannyal és drágakővel ékesítették ezeket az eszközöket. A szintén kortárs Sozomenos egyháztörténeti munkájából egyetlen adat köthető a hunok fegyverzetéhez, melyből a pányvájukra következtethetünk. A kortárs források közül legnagyobb forrásértékkel Priskos és Olympiodoros munkái bírnak, ezekben azonban sajnos nagyon kevés, fegyverzetre vonatkozó adatot találunk. A kései források közül Iordanes és Tours-i Gergely történeti munkáit fontos megemlíteni, melyek szintén sok toposzt tartalmaznak. Míg az előbbi forrásból sok fontos adat nyerhető a hun fegyverzetre vonatkozóan (például az íj és a kard szimbolikus jelentése), az utóbbiban alig található értékelhető információ.

A forrásokban a fegyverek említése többféle kontextusban figyelhető meg. Számunkra legfontosabbak azok a leírások, amelyek a fegyvereket konkrét használat közben említik meg. A hunok esetében erre jó példa a pányva használata Sozomenosnál vagy pedig Sidoniusnál a vértezet jellemzése egy ,párbaj” leírásában. Emellett még szintén jól használhatóak azok a források, melyek a fegyvereket általánosságban jellemzik, például Sidonius sisakismertetése. Semmilyen forrásértékkel nem bírnak azok a híradások, melyek vagy csak a fegyver szó szinonimájaként használnak bizonyos fegyverneveket, vagy pedig szimplán „töltelékszóként” használják ezeket a szavakat, például Tours-i Gergely azon híradása, hogy a hunok karddal pusztítottak el bizonyos területeket.

Az íj és nyíl felépítésére, szerkezetére, típusaikra nem nagyon utalnak a források, kizárólag a régészeti anyagból tudjuk rekonstruálni őket. Sidoniustól tudjuk, hogy ezek a távolsági fegyverek szép mívüek voltak. Viszont e két fegyvert említik legtöbbször a 
kútfők. Emellett a hunok vágófegyvereiről is számos forrás emlékezik meg. Az auktorok híradásaiból a hosszú, egy- és kétélü kard meglétére egyértelmüen, a rövidebb saxok használatára pedig esetlegesen következtethetünk. Mindkét típus használatát alátámasztják a régészeti források. A saxok és a kardok viselési módjával kapcsolatban a Waltharius mondából kiderül, hogy ezt a két típusú vágófegyvert egyszerre viselték, amit a régészeti anyag is alátámaszt: a kardot bal oldalon, a saxot pedig jobb oldalon hordták. Továbbá fontos hangsúlyozni, hogy írott forrásokban ily módon tetten érhető az előbb említett sax elterjedése is ebben az időszakban, amit a régészeti források is alátámasztanak. A régészeti anyagban tehát megfigyelhető, hogy ebben az időszakban nomád hatásra terjedt el a germánok körében a saxok használata. Az íj és a kard jelentőségére utalnak az írott forrásokban felelhető adatok, melyek szerint mindkét fegyver hatalmi szimbólum, méltóságjelző volt. A lándzsákra vonatkozóan nagyon kevés és bizonytalan adat áll a rendelkezésünkre, melyek esetlegesen hosszú döfölándzsára és hajítódárdára utalnak. E nomád nép fegyverzete kapcsán fontos kiemelni a pányvát, melynek a használata természetesen csak az írott forrásokban figyelhető meg. Az auktorok híradásából úgy tünik, hogy ennek a fegyvertípusnak a használata általános lehetett. A pányva a nomád népek jellegzetes fegyverzetének tekinthető, melyet a szomszédos népek (például a gótok) is átvehettek tőlük. A hunok a pányvák több típusa közül valószínüleg az egyszerübb felépítésüt használhatták. A vértezetet említő források adataiból nem tudunk következtetni a páncélzatok típusára, egyedül Sidonius munkája utal arra, hogy a hunoknak lehetett törzspáncélzatuk (is). A hunok a Római Birodalommal való kapcsolatuk során átvehettek bizonyos típusú fegyvereket, például vértezetet is. Emellett azonban megfigyelhető Pacatus híradásából, hogy saját páncélzatuk is volt. Néhány forrás szól a hunok sisakjáról, köztük Sidonius is, akinek leírásából orrvédővel ellátott fejvédőre következtethetünk, melyet egy hunok fennhatósága alatt álló területen előkerült római orrvédős sisak is alátámaszt. A hunok pajzsáról nagyon kevés adatunk van, az írott és a régészeti forrásokból sem következtethetünk szerkezetükre, alakjukra. Néhány esetben az írott forrásokból kapunk információt egyes fegyverek kultikus szerepére is. Az íjak és a kardok esetében figyelhető meg ez a jelenség, miszerint ezeknek a fegyvereknek méltóságjelző szerepük lehetett, emellett a hatalmat szimbolizálhatták. A régészeti anyagban található arany íjak valószínüleg erre a jelenségre utalnak. Fontos megjegyezni, hogy az íj és a kard is kultikus szerepe a steppei nomád népek körében széles körben elterjedt volt, tehát a hunok esetében nem egyedi jelenségről van szó. Az írott forrásokban több helyen fellelhető aranyozott, 
ékkőberakásos díszítés tetten érhető a régészeti anyagban is. A hun korszakra általában jellemző az ékkőberakásos polykróm stílus.

A hadjáratokra történő felkészülésre, a hadsereg felvonulására vonatkozóan a hunok esetében több forrás szolgáltat adatokat számunkra. Sidonius híradásaiból kiderül, hogy a hunok már gyerekkorban megtanultak lovagolni. Néhány forrás utal a vadászatukra is. Valószínủleg más nomád néphez hasonlóan a hunok is ezen vadászatok során gyakorolták be a különböző taktikai elemeket. Nagyon kevés információ figyelhető meg az auktorok híradásaiban e nomád nép felderítési módszereire. Azonban ahhoz, hogy többnyire ilyen sikeresek legyenek a hadjárataik, mindenképpen gyüjthettek információkat a hadjáratok indításakor, majd a hadjáratok során is. A hunoknál is megfigyelhető, hogy a hadjáratok és a csata végeredményét jóslással próbálták megtudni, ennek érdekében béljóslást és csontokból történő jóslást alkalmaztak. A sereg vonulását akadályozó folyón történő átkelést többféle módon oldották meg. Egyrészt télen a befagyott folyón keltek át, másrészt csónakokat és tutajokat alkalmaztak. Ez utóbbi esetben nem lehet egyértelmüen eldönteni, hogy ezeket az eszközöket alávetett segédnépeik vagy pedig saját maguk készíttették. A hadjáratok során legnagyobb probléma volt az utánpótlás kérdésének a megoldása. Ennek egy részét zsákmányolásból oldották meg. Emellett azonban az írott forrásokból kiderül, hogy számukra szükséges dolgok egy részét magukkal is vihették szekereken. Az utánpótlásuk fontos elemét képezte a tartalék lovak biztosítása a hadjáratok során, melyeket, mint néhány auktor híradásából kiderül, többnyire magukkal vitték a hadjáratukra. A Római Birodalommal szövetségben végrehajtott hadivállalkozásaik során, mint ez Zosimos híradásából kiderül, a rómaiak gondoskodhattak az ellátásukról.

Fontos adatokat nyerhetünk a hun hadsereg hadiszerveződésére egy kései skandináv sagából. Megállapítható belőle, hogy a hunok hadiszerveződése is tízes rendszeren alapult. A hunok hadserege századokba, ezredekbe, tízezredekbe szerveződött. Fontos kiemelni, hogy míg más nomád népek esetében ezek az egységek nagyon ritkán érik el a tízezres számot, addig a hunok esetében a század, az ezred és a tízezred ennél valamivel több embert tartalmazott. A forrásokban több esetben találunk utalást a hun hadsereg létszámára vonatkozólag, a középkori forrásokban található számadatok azonban annyira bizonytalanok, megbízhatatlanok, hogy ezekböl nem tudunk következtetni a hun hadsereg létszámára. Több forrás utal arra, hogy a csaták közben alkalmaztak a hunok kiáltásokat, különböző hangadásokat és a kürtjeleket. Ezek többféle funkciót betölthettek. Egyrészt szolgálhattak az ellenség megfélemlítésére, saját „harci kedvük feltüzelésére”, valamint pedig a hun hadseregen belüli csapategységek közötti kommunikációra, katonai 
jelzések továbbítására is szolgálhattak. A pszichológiai hadviselés egy formájának tekinthető az arra irányuló kísérlet is, hogy nagyobb létszámúnak próbálják feltüntetni a hadsereget az ellenség szemében, mint amekkora valójában. A hunoknál arra is találunk példát, hogy annak érdekében, hogy nagyobb létszámúnak látszódjon a hadsereg, varázslási praktikákhoz is folyamodtak. A hadjáratban részt vevő hadsereg táborának védelméröl is gondoskodhattak a hunok, erre egy alkalommal találunk adatot a forrásokban, amikor is Mauriacumnál szekérsánccal védték a tábort.

A források szinte egybehangzóan a hunok könnyüfegyverzetű lovasságát hangsúlyozzák. A könnyüfegyverzetü lovasság haditaktikája esetében megfigyelhető a színlelt megfutamodás, aminek fontos eleme volt a hátrafelé nyilazás. Néhány esetben ehhez a taktikához kapcsolódhatott a bekerítés is, bár erre vonatkozóan a hunok esteében nincsenek adataink. A színlelt megfutamodás taktikája azonban nem tekinthető hun specialitásnak, már hunok színrelépése előtt is megfigyelhető a nomád népek harcmodorában. Továbbá megfigyelhető, hogy ezt a taktikát a letelepült népek is átvették a nomád népektől. Ezzel kapcsolatban azonban felmerül egy olyan nézet is, hogy bizánci és nyugat-európai világban történő meghonosodásában a steppei hatások mellett az Ószövetség és annak kommentárjai (például Szent Ágoston) is jelentős hatással lehettek. A hun hadsereg nehézfegyverzetű lovasságára csak gyér adatok utalnak. Ennek ellenére azonban valószínüsíthető, hogy egy a könnyüfegyverzetü lovasságnál kisebb jelentőségü nehézfegyverzetü lovas egységük is lehetett a hunoknak, melyet vagy keletről hozhattak magukkal, vagy pedig az alánoktól, mint alávetett segédnéptől származhatott. A hunoknál gyalogsággal nem számolhatunk, föként a germán alávetett segédnépek szolgáltathatták ezeket az egységeket a hun hadseregben. Az alávetett segédnépekre vonatkozóan az alánokról, gepidákról, osztrogótokról és a rugiakról vannak adataink. Hun Birodalom esetében is tetten érhető az uralkodót védő testőrség jelenléte, bár biztos adatunk csak Attila az időszakára van, mely szerint a testőrök Attila sátrát védték, és a hun nagykirály kíséretét adták. A hunok hadigépeire három város (Aquileia, Naissus és Aureliana) ostroma esetében vannak adataink, melyekből kiderül, hogy a faltörő kosokat, egyszerübb felépítésü ostromtornyokat, torziós szerkezetủ hajítógépeket, ostromlétrákat használtak az erődített helyek bevétele esetében. Esetleg használhattak égő lövedékeket, és aknaásással is próbálták a falakat megrongálni. Priskos leírásából jól megfigyelhető az ostrom menete is: első lépésben az ostromtoronyszerü szerkezeteken álló íjászok (és esetleg dárdahajítók) folyamatos nyílzáporának hatására a falak mellvédjein harcoló védők kénytelenek voltak visszavonulni. Ekkor vetették be a hunok a nagyszámú faltörő kosukat, melyek 
segítségével megrongálták a falakat. E szerkezetek sikeres müködése után, az ostrom befejező szakaszában alkalmazták a megrongálódott falrészeken az ostromlétrákat.

A hunok, hasonlóan más nomád (és nem nomád) népek könnyüfegyverzetü lovasságához, a nyílzáporral, a színlelt megfutamodás taktikájával stb. elsősorban azt akarták elérni, hogy az ellenség egységes, zárt harcvonalát megbontsák, szétzilálják, ezáltal könnyebben legyőzhessék az ellenfelet. A hunoknál is valószínűsíthető, hogy a legtöbbször nem egységes, zárt hadrendbe állnak föl, hanem kisebb csapategységek egymástól függetlenül, de mégis összhangban hajtották végre a különböző taktikai utasításokat. Erre utalhat például Szent Jeromos egyik levelében vagy Ammianus Marcellinus történeti munkájában azzal, hogy a hunok ide-oda száguldozásairól, hirtelen szétszóródásairól, szétfutásairól számolnak be. Csak az után bonyolódtak közelharcba, hogy sikerült megbontaniuk az ellenfél hadrendjét, ekkor föként karddal és pányvával harcoltak. Ekkor vethették be a nehézfegyverzetü lovasságukat is. 


\section{Az avarok fegyverzete és harcmodora}

A délorosz steppén az 550-es években megjelenő avarok a Bizánci Birodalommal szövetségben elsőként a kelet-európai népeket (onogurok, szabirok, utigurok, kutrigurok, anták) győzték le. A Kárpát-medencei honfoglalásukat követően intenzív támadásokat intéztek a Bizánci Birodalom balkáni területei ellen. Ezek a támadások rendkívül sikeresek voltak, különösen az 590-es évek elejéig. Ugyanis 591-ig Bizánc kétfrontos háborúra kényszerült, a Balkánt támadó avarok mellett a perzsák elleni küzdelmek is lekötötték haderőiket. 591 után azonban Bizánc jelentősebb eröket tudott a balkáni területekre is összpontosítani, legjelentősebb sikert Priskos bizánci fővezér érte el, aki 599-ben seregével mélyen benyomult avar területekre, és többször megverte a kagán csapatát. Ennek ellenére a Bizánc elleni sikeres hadjáratok nem szüntek meg az 590-es éveket követően sem. Az avar honfoglalástól a 620-as évekig terjedő időszak tekinthető az Avar Kaganátus fénykorának, ekkor egyértelműen nagyhatalmi szerepet töltött be Közép-Kelet-Európa térségében. Az avar hatalom megrendülését kül- és belpolitikai tényezők, események együttesen jelezik a 620-as évektől (Konstantinápoly 626-os sikertelen ostroma, a vendek és a délszláv népek elszakadása, Magna Bulgária megalakulása, belháború a kagáni címért). Az Avar Kaganátus nagyhatalmi pozíciójának megszünésével visszaszorult a Kárpát-medencébe, ezt jelzi az is, hogy a külső források ritkán tesznek róla említést. Az avarok történetére vonatkozó források a 8. század folyamán sürüsödnek ismét, amikor is a Frank Birodalom látókörébe kerül a Kárpát-medence. Erre az időszakra a frank offenzíva és a központi hatalom megszűnése és belviszályok a jellemzőek. A 9. század elejére a belharcoktól és a frank támadásoktól meggyengült Avar Kaganátus számára a végső döfés a dunai bulgárok 803 körüli, avarok feletti megsemmisítő diadala volt. ${ }^{213}$

\section{1. Fegyverzet}

Az avarok fegyverzetére vonatkozó adatokat elsősorban bizánci és emellett frank szerzők szolgáltatják. A bizánci-avar háborúk korára görög (kivétel Paulus Diaconus), a frankavar háborúk időszakára latin nyelvü (kivétel Euagrios) források állnak rendelkezésünkre. $\mathrm{Az}$ avarokra vonatkozólag tizenhét jelentősebb írott forrás áll rendelkezésünkre, amelyekben találunk olyan, fegyverzetre alkalmazott kifejezést, amiből esetleg

${ }^{213}$ Az avarok történetére lásd AvenARIUS 1974; BÓNA 1984, 310-346; POHL 1988; SZÁDECZKY-KARDOSS 1990, 206-228; SZÁDECZKY-KARDOSS 1996, 21-30; SZÁDECZKY-KARDOSS 1998. 
következtetni lehet az avarok nehézfegyverzetére. Ebből tíz kortárs híradás: Maurikios (6. század utolsó vagy 7. század első évtizede környékén keletkezett müve), Menandros Protéktór (kb. 583-602), Geórgios Pisidés (kb. 626-627), Theodóros Synkellos (kb. 627), Miracula S. Demetrii (I. könyve 620-630, II. könyve 7. század második felében), Theophylaktos Simokattés (628-638), Alcuin (796), Euagrios (8. század), Karolus Magnus, Capitulare (9. század), Epithapium Geroldi (9. század). Van továbbá hét olyan forrás, melyek későbbi korokban keletkezett: Paulus Diaconus (799), Zonaras (12. század első fele), Manasses (kb. 12. század), Plótinos Thessalonikeus (9-12. század), Nikephoros Kallistos Xanthopulos (kb. 1317), Konstantinos Akropolités (14. század első fele) és Ephraim (14. század).

Az írott forrásokban a támadófegyverek közül a távolsági fegyvereken belül íjról, nyílról és parittyáról vannak adataink. A közelharci fegyverek közül a vágófegyverek, lándzsák, ütő- és sújtófegyverek lelhetők fel a forrásokban. Emellett védőfegyverzetre vonatkozólag is (páncél, sisak, pajzs, lovak vértezete) vannak biztos adataink.

\section{1. 1. Íj}

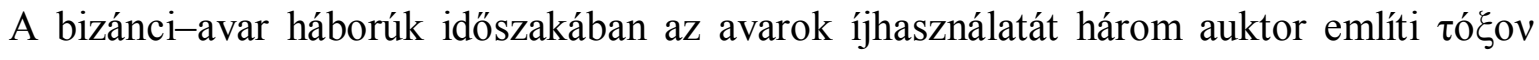
néven: Geórgios Pisidés 113-124; Miracula S. Demetrit I (14) 139; MAURikios XI 2, 6; XI 2, 8. A frank-avar háborúk korszakára vonatkozóan nem figyelhető meg az írott forrásokban ez a fegyver.

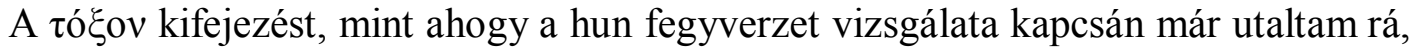
a görög szerzők az íjra általában használták, minden konkrét jelentés nélkül. Ebben az időszakban elsősorban összetett reflexíjat jelentett (KoliAs 1988, 214-215). A régészeti anyagban található leletek alátámasztják az írott források utalásait, miszerint az avaroknak csontlemezzel megerősített összetett reflexíjuk volt (CS. SEBESTYÉN 1931, 178-304; SZŐLLÖSY 2004, 53). A frank-avar háborúk időszakának íjra vonatkozó írott forrásokban található információhiánnyal ellentétben a régészeti leletekből egyértelmüen kitűnik, hogy az íjakat természetesen az Avar Kaganátus teljes időszakában használták. Az íjakra utaló leletek mellett képi ábrázolások is utalnak erre. Ezek közül az Utrechti és a Stuttgarti Psalterium illusztrációin figyelhető meg az avarokkal azonosítható „pogányok” íjhasználata. A két ábrázolás közül fontos kiemelni a Stuttgarti Psalteriumot, ahol a hátrafelé nyilazás is látható [1. kép] (MESTREHÁzy 1968, 245-247; BóNA 1984, 79. kép; 
BACHRACH 1984, 5-24). ${ }^{214}$ Avar kori leleteken is megfigyelhető ennek a fegyvernek a megjelenítése. Erre jó példa a klárafalvi késő avar kori nagyszíjvégen látható avar harcos ijhasználata vadászat közben (KÜRTI-LÖRINCZY 1991, 19; FANCSALSZKY 2007, 111-112).

Az íjvégcsontok felépítése, mérete alapján megállapítható, hogy nem teljesen azonos felépítésü íjat használtak az avarok az egész avar koron át. A kora avar korban keskeny íjvégcsontokkal ellátott íjakkal harcoltak, ${ }^{215}$ amelyek az idő előrehaladtával fokozatosan szélesedtek (CSALLÁNY 1939, 148-149; CSALLÁNY 1946-1948, 364). ${ }^{216}$ Továbbá az is megállapítható, hogy különbözö az íjvégeknek a rugalmas íjkarokhoz történő csatlakozási szöge a kora és a késő avar korban. Ez a különbség gyakorlatilag az ijak teljesítményében is megmutatkozik valamelyest. A felsorolt különbségek ellenére azonban a kora és a késő avar kori íjak egyazon alaptípusba sorolhatók, közös jellemzőjük, hogy e fegyverek esetében az íjak reflexét csupán az íjvégek felhajlása okozta (SzŐLLÖSY $2004,56) .^{217}$

Az avarok esetében ez a fegyvertípus a hunokhoz hasonló méltóságjelzői, hatalmi szimbólumként nem tünik fel az írott forrásokban. Arra vonatkozólag, hogy az avarok esetében is lehetett az ijnak a harcászatbeli szerepével párhuzamosan szimbolikus jelentősége is, csak a régészeti anyagból következtethetünk. Az avaroknál azonban egyetlen lelőhelyen, Kunbábonyban található ilyen típusú lelet. A kunbábonyi - a kutatók egy része szerint kagáni - sírban aranyíj maradványai kerültek elő, melyről H. Tóth Elvira feltételezi, hogy a hun aranyíjakhoz hasonló szerepet tölthetett be ez az eszköz. Véleménye

\footnotetext{
${ }^{214}$ A Stuttgarti Psalterium ábrázolása Dávid király seregének az asszírok felett aratott, körülbelül Kr. e. 1000 környékére datálható győzelmét örökítette meg. Az ábrázoláson Dávid király seregének fegyverzete a 9. század eleji frankok felszerelésével azonosítható: sodronyvért (brunia), pántos sisak (Spangenhelm) és kardgombbal ellátott kardok. A stuttgarti ábrázolás a frank harcosokról jó forrásadatokat nyújt. Dávid király serege ellenfeleinek, a szíreknek az ábrázolása kapcsán azonban nem ilyen egyértelmű a helyzet. Bachrach hívta fel rá a figyelmet, hogy megfigyelhetők rajta olyan elemek, melyek alapvetően „keleti” sajátosságokat mutatnak: a lovasíjász harcmodor, valamint ezen belül a hátrafelé nyilazás. Véleménye szerint az asszír harcosok lovai olyan jellegzetességeket mutatnak, mint amilyenekröl Vegetius ír a hunok hátasai kapcsán: nagyfejüek, elöreugró szemeik és erős, merev nyakuk van, alacsonyak. Bachrach alapvetően úgy véli, hogy az avarok mellett akár hunokat vagy perzsákat is ábrázolhattak ebben a psalteriumban. Az avarokra vonatkozó írott és régészeti források vizsgálata után úgy véli, megalapozott az a vélemény, hogy az ábrázolt szíriai harcosok az avarokkal azonosíthatók (BACHRACH 1984, 5-21).

${ }^{215}$ Például Bóly-Sziebertpuszta 21. sír, Szegvár-Oromdűlő 68., 156. sír (SzÖLLŐsY 1992, 351), Környe 54, 60., 78., 82. sír (SALAMON-ERdÉlyi 1971, 18-19, 21), Kiszombor O. 1. sír (CSALlÁNy 1939, 123), FelgyőÜrmös-tanya 215. sír (BALOGH 2010, 218-219), Zamárdi-Rétiföldek 186. sír (BÁRDOS-GARAM 2009, 3637), Kölked-Feketekapu A. 21. sír (KIss 1996, 25-26); Börcs-Nagydomb 1., 2. sír (ToMKA 2005, 137, 143).

${ }^{216}$ Az íjvégcsontok szélesedésével azonban az íjak teljesítménye nem növekedett, hanem éppen ellenkezőleg, csökkent. A késő avar korban ezek a széles íjvégcsontok egyfajta holt teherként rontották az íjak teljesítőképességét (SzŐLLŐsY 2004, 60). Például Komárom-Hajógyár 107., 114., 119., 131., 142. sír (Trugly 2008, 40, 43, 45, 50, 55), Budapest IX. Régi Lóversenytér 1. sír (NAGY 1998, 59-60).

${ }^{217}$ Lényeges szerkezeti különbség figyelhető meg például a honfoglalás kori és az avar íjak között: míg az avar íjak esetében a fegyver reflexét csak az íjvégek felhajlása adja, addig a honfoglalás kori íjak esetében az íjvégek felhajlása mellett az íjkarok egymás felé hajlása is biztosítja ezt (SzŐLLŐsY 2004, 60).
} 
szerint ez a kunbábonyi „szertartásíj” fejedelmi méltóságjelvény lehetett ${ }^{218}$ (H. TÓTH 1990, 5-11; H. TÓTH-HORVÁTH 1992, 139-144).

\section{1. 2. Nyíl}

A bizánci-avar háborúk korszakában a bizánci szerzők közül az avarok nyilára vonatkozó adatokat a Miracula S. Demetriiben (I (14) 139; II (2) 208) és Plótinos Thessalonikeusnál (9-12) találunk. Mind a két történeti munkában az avarok nyilát $\beta \varepsilon ́ \lambda o \varsigma$ terminussal jelölik. $\mathrm{Az}$ avarok nyilát a frank-avar háborúk időszakában csak egy forrás említi sagitta (PAULINUS AQILEIENSIS 10) alakban.

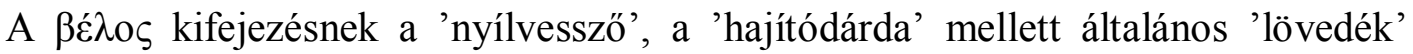
jelentése is ismert (GYÖRKÖSY-KAPITÁNFFY-TEGYEY 1990, 186; LIDDEL et al. 1958, 313). Azonban az avarok $\beta \varepsilon ́ \lambda$ os-át említő két forrás szövegkörnyezetéböl elsősorban a nyílra kell gondolnunk. Plótinos Thessalonikeus Thessaloniké ostromakor sorol fel egymás után

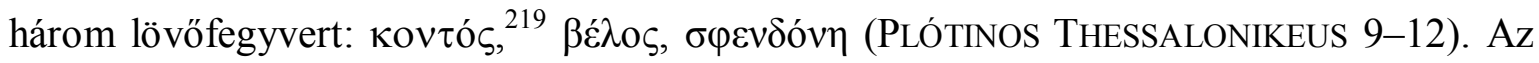
első kifejezés valószínüleg dobódárdára vonatkozik, a harmadik pedig parittyára, így a $\beta \varepsilon ́ \lambda o \zeta-t$ ebben az esetben a kései szerző elsősorban 'nyíl' jelentésben használhatta. A Szent Demeter csodáiban található két részlet esetében a szerző hózáporhoz hasonlítja az avarok sürü lövéseit, valamint megnevezi az avarok nyilainak egyes részeit: a hegyet ( $\sigma i ́ \delta \eta \rho \varsigma$ ) és

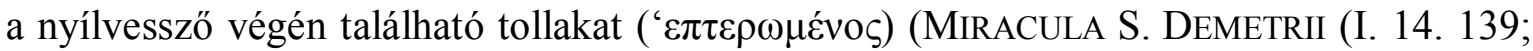
II. 2. 208). Tehát ez esetben is elsősorban a 'nyíl' jelentés a legmegfelelőbb.

A sagitta terminus sem jelöl konkrét típust, a nyíl szóra általában használták a korabeli szerzők (KOLIAS 1988, 218; GLARE 2000, 1679). Az avarokra vonatkozólag Erich friauli gróf 799-ben történt megölése kapcsán említik a nyilat (PAULINUS AQUILEIENSIS 10, vö. SZÁDECZKY-KARDOSS 1998, 301).

Tehát sem a bizánci-avar, sem a frank-avar háborúk korszakára vonatkozólag nem következtethetünk az írott forrásokból az avar nyíltípusokra. A régészeti anyagból azonban kiderül, hogy a kora avar korban elsősorban nyéltüskés, ritkábban köpüs ${ }^{20}$ nyílhegyeket használtak. Leggyakoribbak a nyéltüskés háromélü nyílcsúcsok és azok különböző típusai

\footnotetext{
${ }^{218}$ H. Tóth Elvira feltételezi, hogy ez esetben hun kori tradíció továbbéléséről lehet szó, és valószínüleg az alánok lehettek a közvetítők (H. TóTH 1990, 5-11; H. TóTH-HORVÁTH 1992, 139-144).

${ }^{219}$ A terminus értékelését lásd a lándzsa alfejezetben.

${ }^{220}$ Például Kölked-Feketekapu A. 133., 295., 471. sír (KISS 1996, 49-50, 85, 126-127), Kölked-Feketekapu B 336, 470. sír (KISS 2001, 117, 152-153); Börcs-Nagydomb 1. sír (ToMKA 2005, 139) .
} 
(csapott végü, háromszög alakú, valamint ennek egyenes oldalú és ívelt változatai), amelyeknek a kisebb és keskenyebb példányai páncéltörésre is alkalmasak voltak. ${ }^{221}$ Ezeken kívül még előfordulnak kétélü, lapos, néha villás (KALMÁR 1944-1945, 283-293), átlyukasztott tollú gyújtónyílhegyek és egyenesen lecsapott súlyosabb példányok (KÜRTILŐRINCZY 1991, 6). ${ }^{222}$ A késő avar korban a kora avar korhoz hasonló nyílcsúcsokat használtak (SIMON 1995, 114). ${ }^{223}$ Az írott források nem utalnak az avarok nyíltartó tegezére sem, csak a régészeti anyag szolgáltat erre vonatkozóan adatokat. ${ }^{224}$ Szintén nem utalnak az írott források a nyíltegezek gyakorlati szerepén túl szimbolikus jelentőségükre, szerepükre. Göckenjan a kunbábonyi arany nyíltartó tegezmaradványok kapcsán feltételezi, hogy az avarok szimbólumrendszerében is jelen lehetett a tegez (GöCKENJAN $2005,72)$

\section{1. 3. Vágófegyver}

A bizánci-avar háborúk korszakának vágófegyverzetére vonatkozólag a görög és a latin nyelvü forrásokban ötféle kifejezést találunk: $\sigma \pi \alpha ́ \theta \eta$ (MAURIKIOS I 2, 2; XI 2, 6);

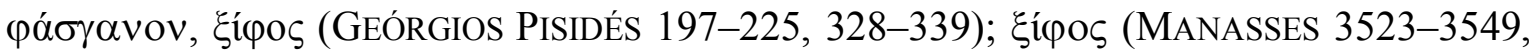
3570-3571; Zonaras XIV 13, 7-23; NiKephoros Kallistos Xanthopulos XVII 28-

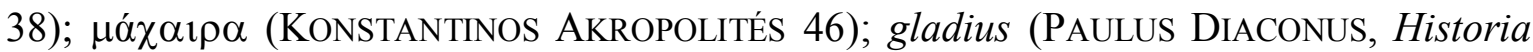
Langobardorum IV. 37-38). A frank-avar háborúk korszakára vonatkozólag két latin és egy görög nyelvü forrásban említik az avarok kardját: sax (EPITHAPIUM GEROLDI 1-4); gladius (ALCUIN 20, 57-58); $\mu \alpha ́ \chi \alpha 1 \rho \alpha$ (EUAGRIOS).

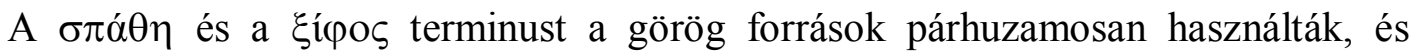
mindkettő általában hosszú vágófegyvert jelentett. Elsősorban lovassági fegyverek voltak. Ezeknek hosszú (70-100 cm), vastag, egy- vagy kétélü pengéjük volt (KoLIAS 1988, 136).

\footnotetext{
${ }^{221}$ Például Szeged-Csengele (CSAlláNY 1939, 148), Kiszombor O. 1 sír. (KalmÁR 1944-1945, 288-289), Környe 10., 18., 60., 66., 71., 78. sír (SALAMON-ERDÉLYI 1971, 15, 19, 20, 21), Mór 21. sír (TÖRÖK 1954, 55), Felgyö-Ürmös-tanya 197. sír (BALOGH 2010, 216), Zamárdi-Rétiföldek 225., 250/a. sír (BÁRDOSGARAM 2009, 41-42, 43-44), Kölked-Feketekapu A 107. sír (KISs 1996, 41-42).

${ }^{222}$ Például Környe 17., 60., 75., 100. sír (SALAMON-ERDÉLYI 1971，15, 19, 20, 23-24), Zamárdi-Rétiföldek 239., 350., 376/a sír (BÁRDOS-GARAM 2009, 43, 56, 59).

${ }^{223}$ Például Komárom-Hajógyár 119. sír (TRUgLY 2008, 45), Budapest IX. Régi Lóversenytér 1. sír (NAGY 1998, 59-60), Budapest X. Rákos-Ejtőernyös torony 25. sír (NAGY 1998, 74), Tiszafüred 594., 776. sír (GARAM 1995, 78, 96).

${ }^{224}$ Fémszerelékes nyíltartó tegezekről lásd LÁszló 1976, 94-96; H. Tóth-HoRvÁTH 1992, 155-160. Csontdíszes tegezekröl lásd TÖRÖK 1954, 55, 58-59; KISS 1997, 75-83; STRAUB 1997, 117-151; STRAUB 2006, 163-177.
} 
A $\mu \alpha ́ \chi \alpha ı \rho \alpha$ kifejezésen leggyakrabban a $\sigma \pi \alpha ́ \theta \eta / \xi i ́ \varphi$ os-nál rövidebb $(40-70 \mathrm{~cm}$ hosszú), egy- vagy kétélü fegyvert értettek. Ritkábban 'tőr' jelentésben is használták (Kolias 1988, 138).

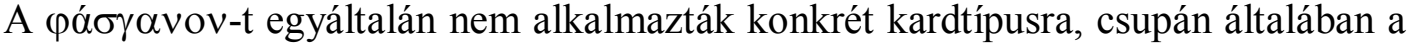
vágófegyverek jelölésére szolgált (KOLIAS 1988, 134).

A gladius a római korban fő támadófegyver volt a pilum (dobódárda) mellett. Ezek rövid, 40-70 cm hosszúságú, keresztvas nélküli kardok voltak, melyeket vágásra és szúrásra egyaránt használtak. A középkorra viszont elvesztette ezt a jelentését, és a kard szóra általában alkalmazták a szerzők. A sax pedig általában hasonló hosszúságú, egyélü vágófegyvert jelentett (KOLIAS 1988, 136; COUPLAND 1990, 42-43).

A nem kortárs szerzők közül a kora avar korra vonatkozólag Zonaras, Manasses és Nikephoros Kallistos Xanthopulos ugyanazon esemény leírásakor ${ }^{225}$ említette az avarok

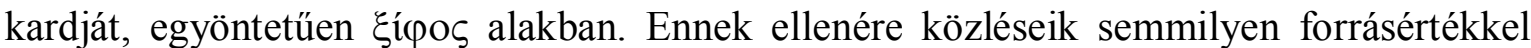
nem rendelkeznek a kardokról, mivel ez a három szerző Theophanestől szerezte értesüléseit, viszont nála az események leírása kapcsán nem található meg a kard terminus (THEOPHANES 6092. vö. SZÁDECZKY-KARDOSS 1998, 128).

A bizánci-avar háborúk korszakára vonatkozólag a kardokat két kortárs forrás

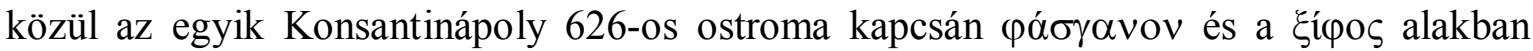
említi. A másik forrás pedig Maurikios műve, amely $\sigma \pi \alpha ́ \theta \eta$ terminust használja. A

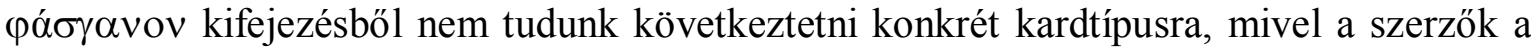

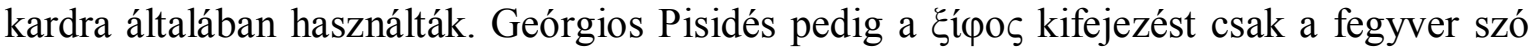
szinonimájaként alkalmazta. Jó forrásértékkel csupán Maurikios közlése bír. Az általa említett $\sigma \pi \alpha ́ \theta \eta$ terminusból arra következtethetünk, hogy az avaroknak voltak hosszú, egyés kétélü lovassági kardjaik (is). Az írott forrásokból nyerhető információt a régészeti adatok is teljes mértékben alátámasztják. A régészeti anyagban a kora avar kor első felében a vágófegyverek közül a hosszú kétélủ kardok használata volt a domináns, ${ }^{226}$ majd a 6-7. század fordulóján jelenhettek meg, és terjedtek el a leletanyagban a hosszú egyélü kardok. $^{227}$ A kora avar kor végére azonban a kétélü kardok használata teljesen

\footnotetext{
${ }^{225}$ Az avar kagán seregével 598-599-es hadjárata során Driziperáig (ma Büyükkariştiran, Törökország) nyomult elöre, a békekötés alkalmával a követek „ajándékai” és a megállapított évpénz mellett a hadifoglyokért is külön aranyat kért. Maurikios császár azonban ezt nem volt hajlandó megadni, és a kagán megölette a foglyokat (THEOPHANES 6092. vö. SZÁDECZKY-KARDOSS 1998, 128).

${ }^{226}$ Például Andocs-Újhalastó 21. sír, Bicske-Óbarok, Bóly, Sziebert puszta 21 sír, Csolnok 13. sír, Deszk O. 1., 2. sír, Kiszombor O. 2. sír, Pápa-Úrdomb 1. sír, Szegvár-Sápoldal (SIMON 1991, 286-306).

${ }^{227}$ Például Bágyog-Gyúrhegy 2. sír, Bugyi, Ürbőpuszta 14. sír, Csákberény-Orondpuszta 86. sír, Gátér 212. sír, Hajdúdorog-Városkert u. 1. sír, Környe 35. sír, Mór-Akasztódomb 25. sír (SIMON 1991, 286-306).
} 
visszaszorult, és az egyélűek alkalmazása vált dominánssá (SIMON 1991, 282-283; CSIKY 2009, 195-197). ${ }^{228}$

A frank-avar háborúk időszakára vonatkozó fegyverterminusok a vizsgált korszakra vonatkozólag már legtöbbször csak általános jelentéssel bírtak. A régészeti anyagból azonban megállapítható, hogy a közép avar korban széles körben elterjedt szablyák jelenléte még ebben az időszakban is megfigyelhető, ${ }^{229}$ de használatuk visszaszorult. A kései avar kor leletanyagában az egyélű kardok túlsúlya a jellemző, ${ }^{230}$ továbbá - bár az írott forrásokban található sax terminus nem sok információértékkel bír a korszakra vonatkozóan - a régészeti anyagban megfigyelhető még a langsaxok használata $^{231}$ is a késő avar korban (GARAM 1991, 156-157; CSIKY 2009, 199-200; CSIKY 2012, 382-384). ${ }^{232}$ A kard és a szablya közötti különbséget az írott források nem érzékeltetik. Nem ismerünk - sem latin, sem görög nyelven - olyan kifejezést, amelyet kizárólag a szablyára alkalmaztak volna az auktorok. Az írott forrásokból tehát nem következtethetünk a közép avar kor jellegzetes vágófegyverzetére.

Az írott forrásokból és a régészeti leletekből kitünik, hogy fontos szerepe lehetett a vágófegyvereknek az avarok harcászatában. Ezzel párhuzamosan a hunokhoz hasonlóan az avaroknál is megfigyelhető ennek a fegyvernek a szimbolikus jelentősége. ${ }^{233}$ Erre vonatkozóan egyrészt Menandros Protéktór történeti munkája szolgáltat bizonyítékot, mely részletesen megemlékezik az 579/580. évi bizánci-avar szerződéskötéskor alkalmazott esküformuláról. Baján először avar szokás szerint a kivont kardja előtt esküdött meg arról, hogy a Száván épülö hidat nem a bizánciak elleni hadba vonulásra akarja használni. Ezt követően az avar kagán azt hangsúlyozta, hogy kard által vesszen el ő maga és egész népe is, ha megszegi esküjét. ${ }^{234}$ Baján végül római szokás szerint is esküt tett (MENANDROS

\footnotetext{
${ }^{228}$ Azonban már a kora avar kor végén megfigyelhető olyan változás egyes egyélü kardokon, melyek a szablya kialakulása felé mutatnak. Ezek a ,protoszablyák” fokéllel vagy ívelt pengével rendelkeztek (SIMON 1991, 271, 285; CSIKY 2009, 198)

${ }^{229}$ Például Tiszafüred-Majoros 496. sír (GARAM 1995, 65), Komárom-Hajógyár 30., 71., 72., 107., 139., 142. sír (TRugly 2008, 19, 27. 28, 40, 53, 54-55, 112)

${ }^{230}$ Például Tiszafüred-Majoros 186. sír (GARAM 1995, 28-30)

${ }^{231}$ Devinska Nova Ves 124., 840., 412., 534. sír, Üllö II.-Vecsési Községhatár 77. sír, Zilingtal D-372, D418, D-451, D-469. sír (CSIKY 2012, 388).

${ }^{232}$ A saxok különböző típusainak a használata az egész avar koron át megfigyelhető (CSIKY 2012).

${ }^{233}$ Makkay János úgy véli, hogy a kard tisztelete a hun uralom alatt is továbbélt az eurázsiai steppén, és az avarok a délorosz steppén vagy ettől még keletebbre ismerkedhetek meg ezzel a szokással. Makkay ezenkívül még hangsúlyozza, hogy ez az eredetileg iráni szokás a 6. század második felére a steppei török nyelvü népek jellegzetes hitévé vált (MAKKAY 1995, 22-24)

${ }^{234}$ A forrásban további önelátkozási jegyek is szerepelnek: az Ég istene küldjön az avarokra tüzet, a környezö hegyek és erdők zuhanjanak rájuk, és a Száva áradata borítsa be öket (MENANDROS PROTÉKTóR 471, 25-476, 25. vö. SZÁDECZKY-KARDOSS 1998, 47).
} 
ProtéKTór 471, 25 - 476, 25. vö. SZÁDECZKY-KARdOSS 1998, 47). ${ }^{235}$ Más nomád népeknél is általában hasonló formulák szerinti szerződéskötési mód figyelhető meg (GÖCKENJAN 1997, 335). ${ }^{236}$ Az eskük és a hozzájuk kapcsolódó rituálék során közvetlen vagy közvetett szerep juthatott a kardoknak is. A kard közvetett szerepe figyelhető meg a kunok és a mongolok esetében, amikor is a karddal szétszabdalt kutyára vagy más állatra tettek esküt (GÖCKENJAN 1997, 338-339). ${ }^{237}$ Az eskütételek során a kard közvetlen szerepe figyelhető meg az avarok mellett más nomád népeknél, ${ }^{238}$ amely esetekben a kardra esküdtek (GöCKENJAN 1997, 342). A kortárs szerző, Menandros Protéktór híradása mellett érdemes megemlíteni még egy kései, 8. század végi - 9. századi szerzőt, Euagriost. A forrás értékelése kapcsán még hangsúlyozandó, hogy a szerző nem a Kárpát-medencei avarokról emlékezik meg, hanem a Dyrrachium és Athén környékén élő, bálványimádó „avarokról” ad hírt. ${ }^{239}$ A kései auktor szerint ezek az avarok a víz és a tüz mellett a kardnak mutattak be áldozatot ${ }^{240}$ (EUAGRIOS vö. OLAJOS 2001, 122, 124). ${ }^{241}$

\footnotetext{
${ }^{235}$ A békekötést követően az avarok mégis blokád alá vonták Sirmiumot (ma Sremska Mitrovica, Szerbia), és megkezdték a város ostromát.

${ }^{236}$ A szerződéskötések alkalmával általában a főszzerep az eskünek jutott, mely lényegében egy szakrális rituálénak tekinthető, és egy vagy több szimbolikus tevékenységből állt. Ezek föként a rituális önelátkozásra vonatkozó jegyeket tartalmazták, melyek következményeivel eskü- vagy szerződésszegés esetén az eskütevőnek számolnia kellett. Ha a szerződést kötő felek különbözö kultúrákból származtak, akkor a másik fél szokása szerint is esküt tettek, ezzel jelezve, hogy tisztelik annak jogfelfogását (GöCKENJAN 1997, 335).

${ }^{237}$ IV. Béla magyar király fiának, Istvánnak a kun fejedelem lányával kötött házassága a mongolok elleni szövetség keretein belül jött létre, melynek során a kunok egy része karddal kettévágott kutyára esküdött, hogy a magyarok földjét meg fogja védelmezni (GöCKENJAN 1997, 339; KATONA 1981, 283-284). IX. Lajos életrajzírója, Joinville emlékezik meg arról, hogy a kun fejedelmek és II. Balduin, az utolsó latin császár közötti szövetségkötés keretében végeztek egy szertartást, amely során egy kutyát karddal darabokra vágtak (GöCKENJAN 1997, 339). Rasíduddín a mongolok kapcsán írja le, hogy eskütételek során karddal levágnak egy csődört, egy bikát és egy kan kutyát (vö. GöCKENJAN 1997, 339).

${ }^{238}$ Például a szkítáknál, a dunai bulgárok és az oguzok esetében is tetten érhető ez a jelenség (GöCKENJAN 1997, 342). Hérodotos leírása szerint az eskütevők a saját vérüket egy nagy agyagcsészében borral összekeverik. A csészébe több más fegyverrel együtt egy kardot is belemártanak, majd az esküszöveg elmondása után megisszák ezt a folyadékot (HÉRODOTOS IV. 70. vö. Muraközi 2000, 289). I. Miklós pápa Borisz dunai bulgár uralkodóhoz írt levelében is megfigyelhetö, hogy a dunai bulgárok egy középre helyezett kardnak tesznek esküt (NICOLAI I. PAPAE Epistolae LXVII).

${ }^{239}$ Erősen kétséges, hogy a forrásban szereplő nép valóban avar lehetett-e. Nyelvük nagy valószínüség szerint szláv lehetett, azonban hagyományaik között fellelhető az egykori avar vezetök steppei hagyományai. Erre utalhat a forrásban található kardkultusz (OLAJOs 2001, 127).

${ }^{240}$ Makkay János ezt a kései, Kárpát-medencén kívül élő avaroknál megfigyelhető adatot összefüggésbe hozza a kora avar kori máglyaleletekkel (tajnyik), ahol a forrás szerinti leírás szerint elégették a temetési szertartás alakalmával feltorolt ló maradványait, a lószerszámzatot és fegyvereket. A tüz elhamvadása után megmaradt darabokat sekély mélységben elásták (MAKKAY 1995, 23-24). Az avar halotti áldozatokról lásd TOMKA 1986, 43-45.

${ }^{241}$ A kardnak bemutatott áldozatokról, a kard istenként történő tiszteletéről lásd a hun fegyverzetről szóló fejezet kardról értekező alfejezetét.
} 


\section{1. 4. Lándzsa}

A görög szerzők esetében a bizánci-avar háborúk időszakának lándzsáira vonatkozó

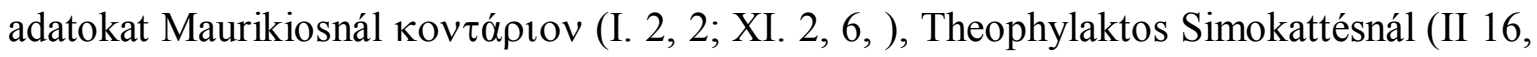

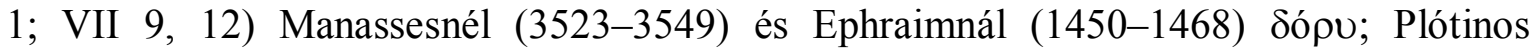

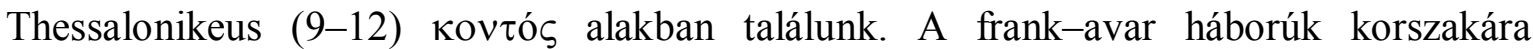
vonatkozó írott forrásokban nem bukkanunk lándzsára vonatkozó kifejezésre.

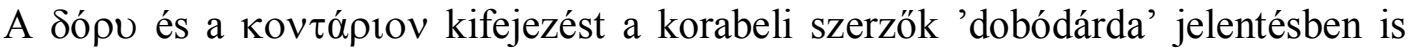
használták müveikben. Ez azonban valószínüleg nem a kifejezések tartalmán múlott, hanem a dárda és a lándzsa közti nem mindig egyértelmü formai és alkalmazásbeli különbségen (KOLIAS 1988, 192). ${ }^{242}$ Az avarok esetében azonban inkább a döfőlándzsa jelentése a mérvadó Maurikios leírásában (SzÁDECZKY-KARDOSS 1998, 80). Erre utalhat a hadászati munka szerzőjének három megjegyzése: az, hogy a lándzsa nyele zászlóval, középen szíjjal van ellátva, illetve, hogy az íjjal felváltva használták az avarok.

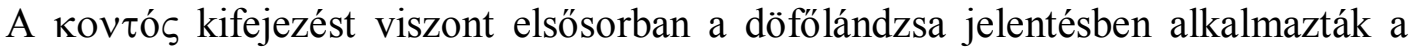
bizánci auktorok (KOLIAS 1988, 192). Ez az avarok esetében használt terminus csak egy kései szerző munkájában tünik fel, és az avarok Thessalonike elleni ostromakor sorol fel

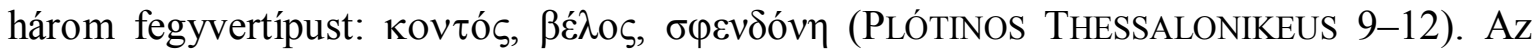

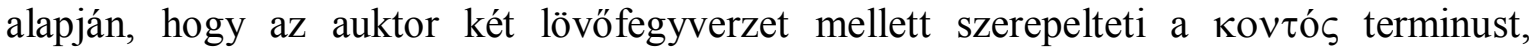
feltételezhető, hogy e kifejezésen is inkább lövőfegyverzetet érthetünk. Tehát ebben az

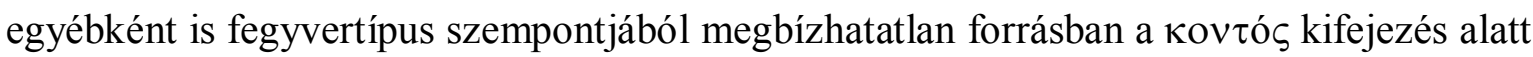
dobódárdát kell értenünk. ${ }^{243}$

A lándzsahegy alakjára, formájára és a hegynek a nyélhez való kapcsolódási módjára az írott források az avarok kapcsán nem adnak választ. Tehát kizárólag csak a régészeti anyagból következtethetünk az avar kori lándzsák típusaira. ${ }^{244}$ Maurikios hadászati munkájában az avarok lándzsájának jellemzéséből csupán az derül ki, hogy a

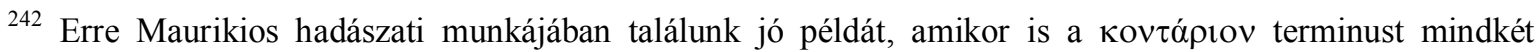
jelentésben használta a szerző. Míg az avarok esetében az I. 2, 2 passzusnál döfőfegyver jelentésben alkalmazta, addig a Stratégikon más részében, a II. 9, 1 passzusban az adott terminus dobódárdaként jelenik meg (MAURIKIOS I. 2, 2; II. 9, 1; SZÁDECZKY-KARDOSS 1998, 80).

${ }^{243}$ A régészeti anyagban szintúgy nehéz elkülöníteni egymástól a két típust. Legutóbb Csiky Gergely tett erre kísérletet. A szerző a viszonylag kisméretü és keskeny köpüjü példányokat sorolja a hajítódárdák közé (CSIKY 2009, 99).

${ }^{244}$ Az avar kori lándzsahegyeket Csiky Gergely tipologizálta, öt fő csoportot (nádlevél alakú lándzsacsúcsok, kihegyesedő, kónikus lándzsacsúcsok, levél alakú pengéjủ lándzsacsúcsok, háromszög alakú pengéjű lándzsacsúcsok, hajítófegyverek), ezeken belül pedig számos alcsoportot különített el (CSIKY 2007, 305-323; CSIKY 2009, 64-99).
} 
lándzsa nyelét középen szíjjal ( $\lambda \omega \rho$ íov), a lándzsahegyet pedig zászlóval ( $\varphi \lambda \alpha \dot{\mu} \mu \nu \lambda \alpha)$ (MAURIKIOS I. 2, 2) látták el.

Maurikios nem jellemzi bővebben az avar lobogókat. ${ }^{245}$ U. Kőhalmi Katalin a steppei nomád népek lobogója esetében elsősorban azt hangsúlyozza, hogy hadijelvényként szolgálhattak. A zászlók kapcsán több típust különített el: véleménye szerint lehettek téglalap alakúak, négyszögletesek, félkörösek. Ezeket a zászlókat rojtok, szalagok és különböző állatalakok (például hal, sárkány, farkas fej) díszíthették (U. KÖHALMI 1972, 115, 123). Legújabban Hansgerd Göckenjan foglalkozott a nomád népek lobogóival, véleménye szerint ezek a tárgyak kettős szerepet töltöttek be: harci jelvényként és uralkodói jelképként is szolgálhattak, emellett még méltóságjelző szerepük is lehetett (GÖCKENJAN 2004, 62-70). ${ }^{246}$ A késő avar korra vonatkozólag a nagyszentmiklósi kincs 2. számú korsóján figyelhető meg a Maurikios által említett lobogó a „győztes fejedelem” ábrázolásán, a lándzsa hegye ${ }^{247}$ alá erősítve [9. kép] (BÁLINT 2004, 364). ${ }^{248}$

\section{1. 5. Ütő- és sújtófegyverek}

Az avar-bizánci háborúk időszakában az avarok esetében baltára vonatkozó adatot a Miracula S. Demetriiben találunk ' $\alpha \xi$ ív $($ I. 14. 139, 147) alakban. A frank-avar háborúk korszakának baltahasználatáról nincs írott forrásos adatunk.

$\mathrm{Az}$ ' $\alpha \xi i ́ v \eta$ terminus egységes és egyértelmű jelentés nélkül fordul elő a bizánci

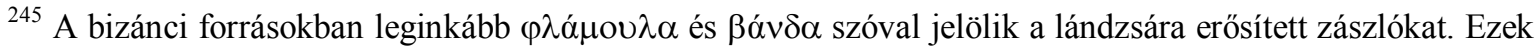
változó alakúak és színűek voltak, és a különböző katonai egységek jelölésére szolgáltak (KoLIAS 1988, 210).

${ }^{246}$ A dunai bulgárok esetében a lófarkas zászló elsősorban hadijelvényként szolgált (NICOLAI I. PAPAE Epistolae XXXIII). Az ujguroknál viszont a zászló az uralkodó uralmi jelképeihez tartozott (GABAIN 1973, 158; GÖCKENJAN 2001, 67). A Kubiláj parancsára összeállított kormányzási kézikönyvben is fellelhető adat, mely szerint a Mongol Birodalom kilenc jelvénye között található a fekete zászló (SAGASTER 1976, 295-299). Emellett a mongoloknál még a fehér zászló egyik változata a nomád uralkodó hadi és hatalmi jelképe mellett a jelentősebb méltóságot viselők szimbóluma is lehetett (OLBRICHT-PINKS 1980, 72-74; GÖCKENJAN 2001, 64-65).

${ }^{247}$ Bálint Csanád a ,győztes fejedelem” ábrázolásán látható lándzsahegyet az Erdély területén előkerült késő avar kori áttört pengéjü lándzsákkal (Tövis/Teius, Románia) hozta összefüggésbe. Emellett a lándzsahegyen látható két lyuk ábrázolását a III. Tiberios bizánci császár (698-705) arany solidusán látható lándzsacsúcsábrázolással is kapcsolatba hozta (BÁLINT 2004, 364).

${ }^{248}$ A belső-ázsiai türk kori ábrázolásokon, valamint Közép-Ázsia területéről származó nomádábrázolásokon is megfigyelhetők a lándzsákra erősített lobogók [10., 11., 12., 13. kép] (MOGILNYIKOV 1981, 126; DOSZIMBAJEVA-GOLDEN-OSZAVA 2013，12，14; TABALDIEV-BABAJAROV-UMIROV-JACENKO 2013，526, 555), valamint a dunai bulgárokhoz köthető ábrázolásokon is megtalálhatók a zászlóval ellátott lándzsák (VITLJANOV 1996, 19. tábla). De mongol kori ábrázolásokon is megfigyelhetö ez a fegyvertípus [7. kép] (HofFmANN 2005, 256). A steppei analógiák mellett Bálint Csanád kiemelte, hogy más népeknél is megfigyelhető ez a jelenség, például a langobardoknál és a bizánci hadseregben (BÁLINT 2004, 364).
} 
forrásokban. ${ }^{249} \mathrm{Az}$ írott források harci balta és famegmunkálásra szolgáló eszköz jelentésben is használták (KOLIAS 1988, 167). Az avarok esetében használt terminusból nem tudunk következtetni a balta típusára, felépítésére. A bizánci-avar háborúk korszakának baltára vonatkozó ' $\alpha \xi \xi i ́ v \eta$ terminusa a thessalonikei avar ostrom kapcsán tünik fel (Miracula S. Demetrii I. 14. 139, 147. vö. SzÁdeCZKY-Kardoss 1998, 115). Ez a kortárs forrás mindkét esetben megjelöli az eszköz funkcióját: vagyis az ellenség falának a megrongálása a cél. Arra, hogy konkrétan harci baltaként is használták volna, az írott forrásokból nem lehet következtetni. ${ }^{250}$ A régészeti anyagban megfigyelhető az auktor által említett egyszerü balta is, ${ }^{251}$ emellett számos típusa ismert az ütő- és sújtófegyvereknek a kora és a késő avar korból egyaránt. ${ }^{252}$ A régészeti anyagból úgy tűnik, hogy a késő avar korban az ütő- és sújtófegyverek jelentősége megnövekszik. Megfigyelhető, hogy ezeknek fegyvereknek a száma a kora avar kortól a késő avar korig fokozatosan emelkedik, a késő avar korban pedig jelentősen megnő a számuk (SIMON 1995, 119; SzÜCSI 2012, 121-129).

\section{1. 6. Parittya}

A bizánci-avar háborúk korszakának parittyahasználatára két forrásból következtethetünk:

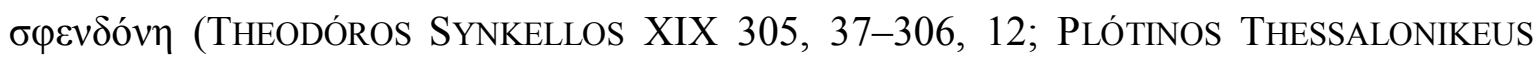
9-12). A frank-avar háborúk időszakára vonatkozólag az avarok parittyájáról egyetlen adatunk van: funda (PAUILNUS AQUILEIENSIS 10).

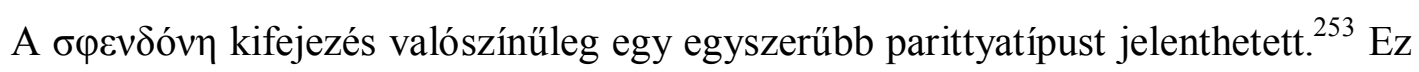
a fegyver két szíjból állt, melyek egy vastagabb bördarabot fogtak közre, ebbe helyezték a

\footnotetext{
${ }^{249}$ A vizsgált korszaknál jóval korábbra vonatkozólag Homéros ezt a kifejezést 'harci balta' jelentésben alkalmazza (KoliAs 1988, 167).

${ }^{250}$ A bizánci hadseregben a 9-10. századig nem volt nagy jelentősége a harci baltának. A kora bizánci századokban a bizánci seregek a baltát elsősorban hadigépek, hajók építésére és bozótos utak szabaddá tételére alkalmazták (KoLIAS 1988, 162-164). Ezzel párhuzamosan nem is alakult ki az ütö- és sújtófegyverek terminológiája

${ }^{251}$ Például Zamárdi-Rétiföldek 330., 516., 1135. sír (BÁRdos-GARAm 2009, 54, 76, ), Budapest III. Pusztadombi út 12. (NAGY 1998, 32), Veszprém-Jutas 130. sír (SZÜCSI 2012, 124).

${ }^{252}$ Például fokosok: Zamárdi-Réti földek 350., 535., 701., 1392. sír (BÁRDOS-GARAM 2009, 56, 80, 100 , 182-184), Budapest XXI. Csepel-Háros BVM 28. sír (NAGY 1998, 152), bárdok: Zamárdi-Réti Földek 1324. sír (BÁRDOS-GARAM 2009, 172), Budapest XXII.-Vöröskereszt u. 65. 13. sír (NAGY 1998, 191-197); szekercék: Zamárdi-Réti Földek 563., 738. sír (BÁRDOS-GARAM 2009, 83, 103), Környe 125., 147. sír (SAlAmON-ERdÉLYi 1971, 26, 28), Kölked-Feketekapu A. 21. sír (Kiss 1996, 25-26), Komárom-Hajógyár 128., 142. sír (TRUGLY 2008, 49, 55).

${ }^{253}$ Ezen egyszerủ változaton kívül még két típus ismert, ezek azonban az avarok fegyverzete kapcsán nem tünnek fel. A botparittya (fustibalus) esetében a lendítőszíj hiányzik, és ezt egy rőfnyi hosszú, kampós végü bot helyettesíti (KOLIAS 1988, 255). A szakállas parittya (mattiobarbulus) börszíjra erösített ólomgolyó volt, amit körülbelül úgy dobtak el, mint a kalapácsvetők a kalapácsot. Ezek a fegyverek nagyon súlyos sebet ejtettek (VEGETIUS I. 17. vö. Várady 1963, 766).
} 
lövedéket. ${ }^{254}$ A parittyás a lövedék belehelyezése után a két szíjat megfogva egyszer vagy többször megforgatta a feje körül, ezután pedig elengedte a szíjat, és a lövedék kirepült

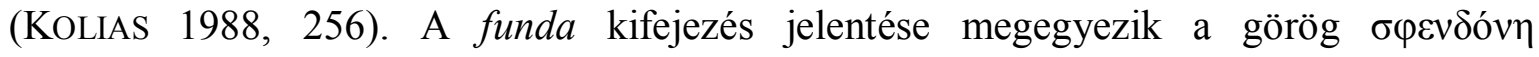
terminussal, vagyis egyszerü felépítésüek lehettek ezek az eszközök (KOLIAS 1988, 255).

Vegetius kiemeli ennek a fegyvernek a jelentőségét, véleménye szerint sokkal hatékonyabb volt, mint például a nyíl. Fémsisakot és fémvértezetet viselő harcosokon is halálos sebet lehetett vele ejteni (VEGETIUS I. 16. vö. Várady 1963, 765-766).

A korai avar hadsereg parittyahasználatáról egy kortárs és egy nem korabeli forrás szól, melyek a Maurikios idején történt thessalonikei ostrom és Konstantinápoly ostroma kapcsán említik az avar parittyát. A késő avar korra vonatkozólag csak egyetlen forrás örökítette meg Erich friauli gróf 799-es halála kapcsán az avarok parittyáit. A parittyák alkalmazására viszonylag kevés írott forrás áll rendelkezésünkre. Ennek az olcsón előállítható, egyszerü felépítésü fegyvernek a használata általános lehetett. ${ }^{255}$ Alkalmazták ezeket a fegyvereket a római hadseregben, és később a középkor folyamán a bizánci hadseregben, valamint Nyugat-Európában is (HAHN 1963, 87; COULSTON 2002, 13). Mivel egyszerü felépítésű volt, elsősorban a köznép fegyvere lehetett. ${ }^{256}$ Magát a parittyát könnyen el lehetett készíteni, és használatát megtanulni is viszonylag egyszerü volt. Föként a könnyüfegyverzetű gyalogság fegyvereként tünik fel a forrásokban. Emellett azonban a könnyüfegyverzetü lovasság fegyverzete között is megtalálható a parittya, valamint az ostromok esetében is bevetették (HAHN 1963, 87; KOLIAS 1988, 257-258; ANONYMUS 13., 32., 32., 35-37. vö. Dennis 1985, 41, 99, 100, 109; Nikephoros Ouranos 4., 65. vö. McGeer 1995, 91, 159; MCGEER 1995, 209). Vegetius a korábbi időszakra vonatkozóan szintén kiemeli ennek a fegyvernek a hasznosságát. Könnyen megtanulható, könnyen szállítható eszköz volt, kőben gazdag területeken pedig kifejezetten előnyös volt az alkalmazása (VEGETIUS I. 17. vö. VÁRADY 1963, 766). A nyílt csatákban esetében bevetett parittyásoknak föként az volt a szerepük, hogy az ellenfél egységes arcvonalát megbontsák. A források hangsúlyozzák, hogy a parittyák lövedékeitől nagyon megzavarodtak az ellenfél lovai, fékezhetetlenné váltak, és ez által bomlott meg az ellenfél hadrendje (ANONYMUs 13., 32., 35-37. vö. Dennis 1985, 41, 99, 100, 109). Tehát hasonló célt szolgáltak, mint a nomádok esetében a könnyüfegyverzetü lovasíjászok. A nomád

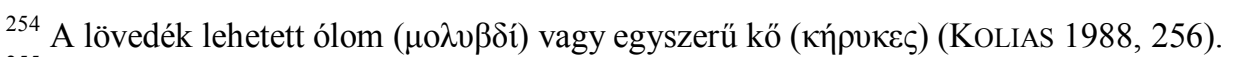

${ }^{255}$ A katonai összecsapások mellett a vadászok is előszeretettel használták ezt a fegyvert (MCGEER 1995, 209).

${ }^{256}$ Ahogy McGeer fogalmazta meg: a szegény ember fegyvere volt (MCGeER 1995, 209)
} 
népek hadseregében nem terjedt el széles körben ennek a fegyvernek a használata, ${ }^{257}$ valószínűleg Bizánból vagy Nyugat-Európából vehették át a parittyát az avarok.

\section{1. 7. Páncél}

A bizánci-avar háborúk korszakának fegyverzetét említő bizánci források a páncélt

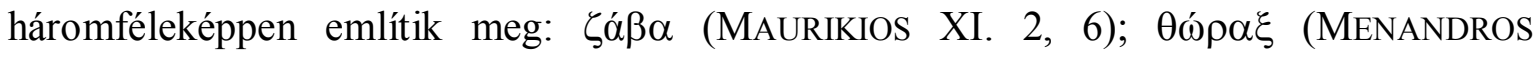
ProtéKTóR EL. 208, 11-210, 2; TheOdÓROS SyNKellos XVIII 305, 13-36; XXIV 308,

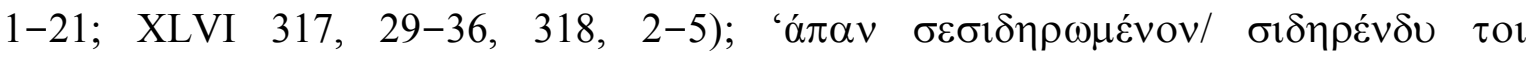

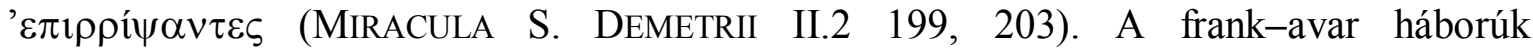
korszakának páncélhasználatára csak egy közvetett adatból következtethetünk Nagy Károly 805. évi dietenhofeni rendeletéből.

A középgörög forrásokban megjelenő $\zeta \alpha ́ \beta \alpha$ terminus a vas sodronypáncélt jelentette. ${ }^{258}$ Ez a kifejezés a 6. században tűnt fel a forrásokban, és csak a 7. század végéig volt domináns a használata ${ }^{259}$ (KoliAs 1988, 38-39). ${ }^{260}$ A Maurikios hadászati

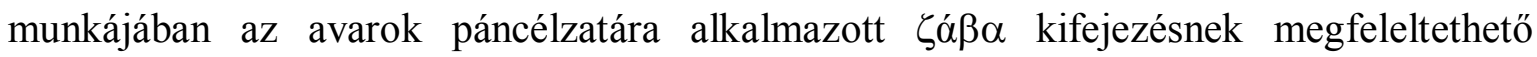
sodronypáncél megtalálható az avar régészeti anyagban, de ez a típusú vértezet viszonylag ritka leletnek számít, ${ }^{261}$ az avar korban a lemezpáncélzat használata volt a leginkább elterjedt.

Az ógörög eredetü $\theta \omega ́ \rho \alpha \xi$ terminus a páncélok minden fajtáját jelölte: gyürüs-

\footnotetext{
257 A honfoglaló magyaroknál Gerhard munkájából következtethetünk esetlegesen parittyahasználatra (GERHARD 12. vö. HKÍF 235). A kortárs forrás Augsburg ostrománál említi, hogy nyilak és kövek zúdultak a városra, és ez utóbbira a lapidus kifejezést alkalmazza (GERHARD 12), amely az egyszerü 'kő' jelentésen kívül kölövedéket is jelent. Ezt a lövedéket vagy parittyából vagy ostromgépbőll löhették ki. Ebben a passzusban ugyan megemlíti a szerző az ostromszerkezeteket (instrumentum), de elképzelhető, hogy mindkét kőhajító eszközt együttesen alkalmazták ostrom közben (GERHARD 12).

${ }^{258}$ A láncpáncélzatot a bizánciak a rómaiaktól vették át (KOLIAS 1988, 37-38).

${ }^{259}$ A 8. századtól a gyürüspáncél jelölésére föként a $\lambda \omega \rho i ́ k ı$ ov terminust alkalmazták. A 6-7. században ritkábban figyelhető meg ez a kifejezés a forrásokban, a $\zeta \dot{\alpha} \beta \alpha$ terminus háttérbe szorította (KoLIAS 1988, 37-38). Erre jó példa Bölcs Leó Taktika címủ munkájának honfoglaló magyarokra vonatkozó részlete. A bizánci császár szinte teljes egészében átvette Maurikios Stratégikon címü hadtörténeti munkájából az avarok fegyverzetére vonatkozó részt. A páncélzat esetében azonban változtatott, és a Maurikios által használt $\zeta \alpha \dot{\alpha} \beta \alpha$ terminust kicserélte a $\lambda \omega$ píkıov kifejezésre (BöLCS LEÓ XVIII. 47; MORAVCSIK 1951, 352-353; KovÁCS 2002, 316-317).

${ }^{260}$ Elkészítésük fejlett technológiát és magas költségráfordítást igényelt. Minél finomabb volt az egyes gyürük kivitelezése, minél sürübben összefonódtak, annál értékesebbnek számított egy páncél. A bizánci lovasok gyürüspáncélzata általában bokáig ért. Egyrészt azért, mert a lovasok lábát az ellenség fegyvere veszélyeztette, másrészt a gyalogosoktól eltérően ök nem igényelték a lábak teljes szabadságát. Kis szíjak, csatok lógtak rajtuk, amelyeknek a segítségével állíthattak a páncélok hosszúságán állítani (KOLIAS 1988, 41-43).

${ }^{261}$ Például Szeged-Kundomb 116. sír, Klárafalva-Kukutyin 7. sír, Jutas 79., 86. sír, Gátér 45., 174., 252. sír (CSALLÁNY 1972, 22-31), Zamárdi-Rétiföldek 738. sír (BÁRDOS-GARAM 2009, 103).
} 


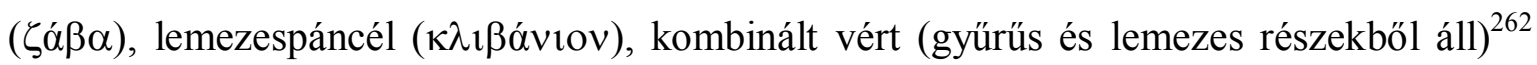
szinonimájaként is előfordul a forrásokban, de más összetételü páncélokra is alkalmazták. A $\theta \omega ́ \rho \alpha \xi$ elsősorban bokáig érő páncél volt, de épp általános jelentése folytán mellvértet is jelölhetett (KoliAS 1988, 37). A bizánci forrásokban az avarokra vonatkozó részekben a $\theta \omega ́ \rho \alpha \xi$ egyértelműen a lovasok vértezetét jelölte. ${ }^{263}$

A Miracula S. Demetriiben található terminust ('á $\pi \alpha \nu \sigma \varepsilon \sigma 1 \delta \eta \rho \omega \mu \varepsilon ́ v o v$ /

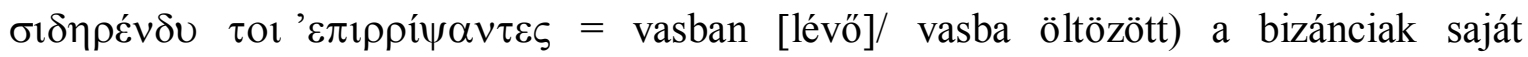
páncélzatukra nem alkalmazták (legalábbis hadászati müvekben nem jelenik meg ez a terminus). A kifejezésből nem tudunk következtetni arra, hogy milyen típusú vértről lehet szó, csak annyit tudunk biztosan megállapítani, hogy fémből készült.

A régészeti anyagból kiderül, mint ahogy már utaltam rá, hogy az avaroknál a lemezes vért darabjai gyakoribb leletek a gyürüsvértnél (CSALLÁNY 1960b, 17-22; CSAlláNY 1972, 9-41; CSAlláNY 1982, 5-11; PÁSZTOR 1995, 60-63). ${ }^{264}$ Egyértelműen lemezpáncélokra utaló kifejezést a bizánci források csak a 10. századtól kezdtek el

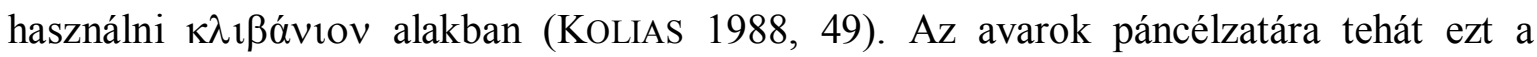
terminust nem alkalmazhatták (az avarok vértezetét csak kortárs források említik). Az

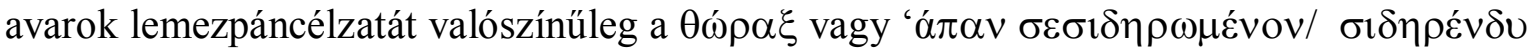

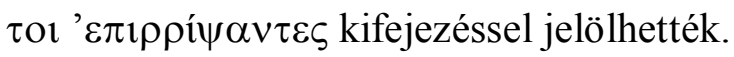

A frank-avar háborúk korszakában használt egyik páncéltípusára a 805. évi dietenhofeni rendeletből következtethetünk, ${ }^{265}$ amelyben a páncél szót brunia terminussal

\footnotetext{
${ }^{262}$ A két típus kombinálása ritkán, és leginkább a nehézfegyvereseknél fordul elő a bizánci hadseregben. Ebben az esetben a lemezes törzspáncélzat szegélyéhez gyürüspáncélzatot erősítettek. Vagyis a vastag lemezpáncélt a mozgás megkönnyítése miatt a karokon és a nyakon sodronypáncéllal helyettesítették (KolIAS 1988, 48). A lemezes és láncpáncélzat kombinálása a tiszavasvári-koldusdombi 1. sírban érhető tetten, ahol a lemezes törzspáncélzat szegélyéhez gyürüspáncélzatot erősítettek. Vagyis a vastag lemezpáncélt a mozgás megkönnyitése céljából a karokon és a nyakon sodronypáncéllal helyettesítették (CSALLÁNY 1960a, 64).

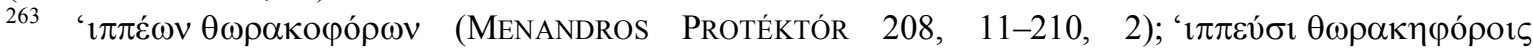

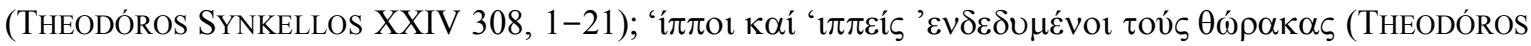
SYNKELLOS XLVI 317, 29-36; 318, 2-5)

${ }^{264} \mathrm{Az}$ avar kori sírokban többnyire csak néhány darab lamella került elő. Előfordulásukból megállapítható, hogy a kora avar korban sem tekinthetők gyakori leletnek, a 7. század második felétől pedig még kevesebb példány kerül elő a sírokból. Teljes lemezes vért a kunszentmártoni ötvössírban található, és egy nagyobb részlet került elő a hajdúdorogi 1. számú sírból. Ezeknek a páncéloknak a lamellái nem egysablonúak, hanem különböző típusúak, amelyek alakban, méretben és füzőlyuk-elosztásban is eltérnek egymástól; attól függően, hogy a lamellák milyen célt szolgáltak, és a páncél melyik pontjához tartoztak (CsALLÁNY 1960b, 17-22; CSALLÁNY 1972, 9-41; SZENTPÉTERI 1993a, 206-209; PÁSZTOR 1995, 60-63).

${ }^{265}$ A 9-10. század folyamán a Frank Birodalomból akkora mennyiségü fegyvert szállítottak Kelet-Európába, hogy Nagy Károly és utódai kénytelenek voltak rendeletekkel a fegyverkivitelt tiltani. Ilyen rendeletek születtek még 779-ben, 781-ben, 803-ban és 811-ben is. Még 864-böl is ismerünk ilyen tiltó rendeletet, mely szerint halálbüntetést kaphat az, aki királyi rendelet nélkül ad el páncélt és fegyvert (POLGÁR 2004, 93-94).
} 
jelölik. A forrás arról szól, hogy Nagy Károly megtiltja a páncélok (brunia) és a fegyverek $(a r m a)^{266}$ szállítását szláv és avar területekre (KAROLUs MAGNuS, Capitulare 44, 7). Ebből következtetni lehet arra, hogy korábban (805 előtt) valószínűleg szállítottak avar területekre frank típusú páncélokat, fegyvereket. ${ }^{267} \mathrm{~A}$ brunia és lorica terminust ${ }^{268}$ a páncélra általában használták: az írott forrásokban feltünik sodronyvérként és lemezpáncélzatként is (CouPLAND 1990, 39-40). A brunia szó 779-től jelenik meg először Nagy Károly Capitulareiban. Kezdetben csak törzspáncélzat volt, később, a 9. században a kart és a lábakat is védte (BRUENNE.htm). Tehát a frank-avar háborúk korszakának frank típusú páncélhasználatról egyetlen közvetett adatunk van, melyböl nem lehet általános következtetéseket levonni. Az azonban valószínü, hogy nyugati hatásra az avarok használhattak frank típusú vérteket (is). ${ }^{269}$

Tehát a forrásokból egyértelműen következtethetünk az avarok páncélhasználatára, valamint arra is, hogy többféle típusút alkalmaztak: ezek lehettek saját gyártmányok és importok is. ${ }^{270}$

\section{1. 8. Sisak}

Az avarok sisakjára utaló források közül egy közvetlenül $\pi \varepsilon \rho ı \kappa \varepsilon \varphi \alpha \lambda \alpha i ́ \alpha$ (THEODÓROS SYNKELLOS XVIII 305, 13-36), egy pedig közvetve $\pi \varepsilon \rho \iota \rho \alpha \chi \eta ́ \lambda ı$ (nyakvédő) (MAURIKIOS I. 2, 2) néven nevezte. A frank-avar háborúk korszakára vonatkozó források nem említik az avarok sisakját.

A bizánci szerzők a sisakra vonatkozó kifejezéseket minden lényeges különbség

\footnotetext{
${ }^{266}$ A forrás nem nevezi meg pontosan a támadófegyverek típusait. A lándzsák tekintetében erre jó példa a 8 . században az Avar Kaganátus nyugati peremterületén nyugati hatásra megjelenő, a szárnyas lándzsák előképének tekinthető keskeny pengéjü, kampós lándzsacsúcs (CSIKY 2009, 95, 225).

267 Ebben az időszakban nagymértékủ frank fegyvercsempészés folyt Skandináviába és a frankoktól keletebbre eső területekre (FISCHER-FABIAN 2000, 75). Valószínű tehát, hogy 805 után is kerültek az avarokhoz frank típusú páncélok.

${ }^{268}$ Nem teljesen világos, hogy vajon egymás szinonimájának tekinthető-e a két terminus vagy két, egymástól különböző páncéltípusra vonatkoztak. A frank rendeletekben található információk alapján azonban úgy tủnik, hogy a két kifejezés jelentése ugyanaz volt. Valószínüleg tehát csak nyelvi különbség lehetett a kettő között: a brunia germán eredetủ szó, a lorica pedig latin (CouPLAND 1990, 39).

${ }^{269}$ A régészeti anyagban a késő avar korban kevesebb számú páncéllelet került elő a kora avar korhoz lépest. Erre a korszakra vonatkozólag érdemes még megemlíteni a nagyszentmiklósi kincs 2. számú korsóján látható győztes fejedelem és a balatonszőlősi veret lovasának vértezetét (SZENTPÉTERI 1993a, 209; BÁLINT 2004b, 416-420; FANCSALSZKY 2004, 113).

${ }^{270}$ Bachrach már eléggé meghaladott nézete szerint az avarok nem voltak képesek nagy mennyiségú előállítására. A bizánci-avar háborúk időszakára vonatkozólag Menandros Protéktór munkájára (MENANDROS PROTÉKTÓR 443, 29-444, 31. vö. SZÁDECZKY-KARDOSS 1998, 22), a frank-avar háborúk időszaka esetében pedig a 805-ös dietenhofeni rendeletre hivatkozva (KAROLus MaGnus, Capitulare 44, 7. vö. SZÁDECZKY-KARDOSS 1998, 307), úgy véli, hogy az avarok ezeket a fegyvereket megvásárolták, és nem maguk készítették (BACHRACH 1984, 20).
} 
nélkül használták egymás mellett személyes ízlésüknek és stílusuknak megfelelően. Anyagukat tekintve vasból, ritkábban bőrből vagy nemezből készültek. A sisak két leggyakoribb formája a félgömbös pántos és a hegyesedő kónikus alakú ${ }^{271}$ (KOLIAS 1988, 75-76). Tehát az avarok sisakjára utaló terminusból sem következtethetünk konkrét típusra. Theodóros Synkellos leírásából - akinél konkrétan olvashatunk az avarok

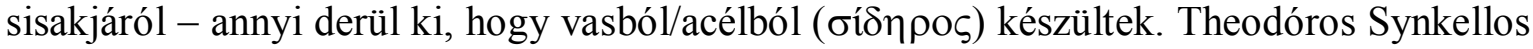
Konstantinápoly 626-os ostroma kapcsán említi az avarok sisakját. A forrásból kitűnik, hogy használata elterjedt volt az avar seregben. ${ }^{272}$ Ennek ellentmond két fontos momentum: más forrás nem említi konkrétan az avarok sisakját, másrészt SzádeczkyKardoss Samu véleménye szerint ez a részlet talán tartalmaz „valami biblikus reminiszcenciát” (SZÁDECZKY-KARDOSS 1998, 188). A régészeti források részben alátámasztják Theodóros Synkellos értesülését. A kora avar kori régészeti anyagban ismert néhány sisakra utaló lelet, azonban ez ritka jelenségnek tekinthető. ${ }^{273}$ A késő avar korra vonatkozólag azonban sem írott forrás, sem régészeti anyag nem tanúskodik az avar fejvédő meglétéről. Ugyanakkor néhány képi ábrázolás utal a sisakok használatára ebben a korszakban is. $^{274}$

A felvértezett katona a sisak és a páncél találkozásánál támadt résen sérülhetett a leggyakrabban csata közben, ennek ellensúlyozására alkalmazták a nyakvédőt. Ez a

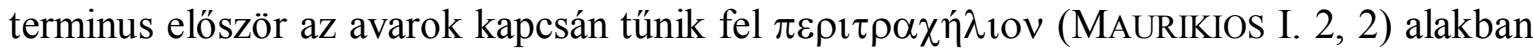
(Kolias 1988, 78-80):

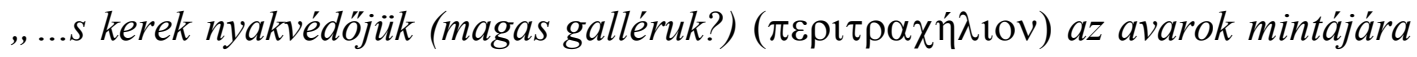
kívül len-, belül gyapjúszalagok (csíkok) sorából (?)” (MAURIKIOS I. 2, 2, ford. SZÁDECZKY-KARDOSS 1998, 80).

\footnotetext{
${ }^{271}$ A bizánci források megkülönböztetnek „teljes” ( sisakokat. Az előbbit a görög hadseregben a nehézfegyverzetü, az utóbbit a könnyüfegyverzetü lovasok használták. A kettő közötti különbség az, hogy a teljes sisakot ellátták arcvédővel. Az arcvédő elöl a szemekig ért, és fül-, illetve nyakvédővel volt ellátva (KoLIAS 1988, 77).

272, ,...Mindannyian sisakot viseltek ... Kelet felé rájuk tüzö nap, amely sugaraival megcsillogtatta az acélt, még félelmetesebbnek mutatta öket, és megrettentette a rájuk tekintöket (THEODÓROS SYNKELLOS XVIII 305, 13-36, ford. SZÁDECZKY-KARDOSS 1998, 186)

${ }^{273}$ A legteljesebb állapotban a kora avar korra datálható a mezöbándi pántos sisak (X. sír) maradt meg (KovÁCs 1913, 13. kép). Németszentpéter/Sânpetru German határában lovassírból került még elő lamellás vassisak töredéke (ERDÉLYI 1982, 175-177). Ezenkívül a bácsújfalusi arcvédő lemez (CSALLÁNY 1953, 134, 138-139) és a hajdúdorogi poncolt bronzkorong esetében feltételezhető biztosan, hogy sisakok részét képezhették. Ez utóbbi esetében egy bőr- vagy nemezlamellákból álló sisak rekonstruálható, melynek a tetején a lamellák összedolgozását fedhette, díszíthette ez a lelet (LŐRINCZY-STRAUB 2012, 399-400).

${ }^{274}$ A Stuttgarti és Chludovi Psalterium illusztrációin, a balatonszőlősi övvereten és a nagyszentmiklósi kincs 2. számú korsóján láthatók. A stuttgarti példányon azonban nem a korszakra jellemző pántos vagy lamellás típus figyelhetô meg, hanem egy egyszerü, fémlemezböl készült kónikus sisaktípus (BACHRACH 1984, 21).
} 
Maurikios nehezen értelmezhető leírását Bölcs Leó müvének egy részlete teszi világossá, melyből kiderül, hogy a len és a gyapjú is csak a nyakvédő béléséhez (' $\varepsilon v \delta \varepsilon \delta v \mu \varepsilon ́ v \alpha)$ tartozott, mely felett lánc- vagy lemezpáncél volt (BÖLCS LEÓ V. 5). Ez a

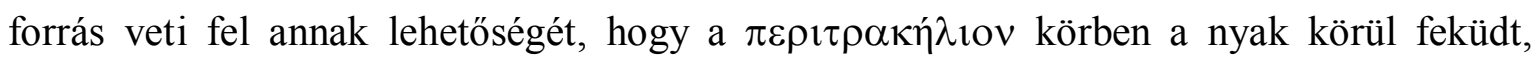
felnyúlt a sisakig, és a mellnél a páncéllal átfedésben végződött (KOLIAS 1988, 79-80). A forrásból tehát közvetve, de következtethetünk az avarok sisakjára is. Maurikios valószínűleg az avaroktól átvett újítást, a nyakvédőt akarta kiemelni, hangsúlyozni.

\section{1. 9. Pajzs}

Az avarok pajzsát háromféle elnevezéssel említik a görög nyelvü források a bizánci-avar háborúk időszakára vonatkozólag: ' $\alpha \sigma \pi ı \varsigma$ (Miracula S. DEMETRII I 123; GEÓRGIOS

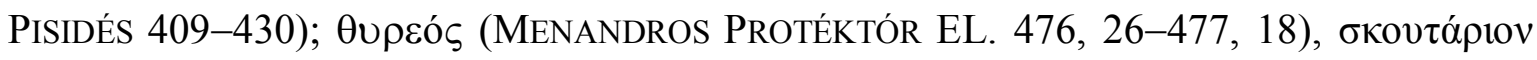
(MAURIKIOS XII. 10, 5-8). A késő avar korra vonatkozó írott források nem említik az avarok pajzsát.

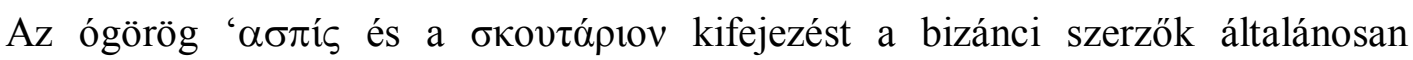
használják, alakjára, típusára pusztán a kifejezésből nem lehet következetni (KOLIAS 1988, 89).

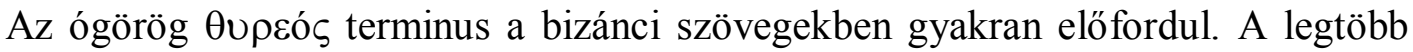
forrás nagy, hosszúkás pajzsnak határozza meg (KOLIAS 1988, 91).

Az avarok pajzsát említő források közül kettő a bizánci városok (Thessalonike, Konstantinápoly) ostromakor említi ezt a fegyvertípust, mely védelmül szolgált a városbeliek lövéseivel szemben. Ezenkívül Maurikios az avarok vadászata alkalmával emlékezik meg róla, és Menandros Protéktór az avar kagánt védelmező pajzsokról számol be. A források közül egyedül Menandros Protéktór munkájából következtethetünk a pajzs szerkezetére: a szerző szerint „,bőrpajzsaik”, vagyis bőrrel bevont pajzsaik voltak az avaroknak. Tehát a forrásból régészetileg nem megfogható, szerves anyagból készült, könnyűszerelékes pajzstípusra gondolhatunk. Emellett a kora avar korban fémszerelékes pajzsok is megfigyelhetők, melyek germán hatásra jelenhettek meg az avar régészeti anyagban. ${ }^{275}$ A frank-avar háborúk korszakára vonatkozólag a pajzsokra a sisakokhoz hasonlóan csak ábrázolásokból, az Utrechti és a Chludovi Psalterium illusztrációiból

\footnotetext{
${ }^{275}$ Például Környe 66., 44., 78., 99. sír (ERDÉlyi-SALAMON 1971, 56), Pókaszepetk 76. sír (SALAMON-Sós 1995, 74), Kölked-Feketekapu A. 14., 39., 211., 260. sír (KISs 1996, 238).
} 
következtethetünk [1. kép]. ${ }^{276}$

\section{1. 10. A lovak vértezete}

A bizánci-avar háborúk időszakában három esetben említik az auktorok - Maurikios és Theodóros Synkellos - az avarok lovainak páncélzatát. Maurikios müvében két helyen is találkozunk a lovak felvértezésével:

„,Kell, hogy a lovak elsösorban a vezetök és a válogatott harcosok lovai ... legyenek

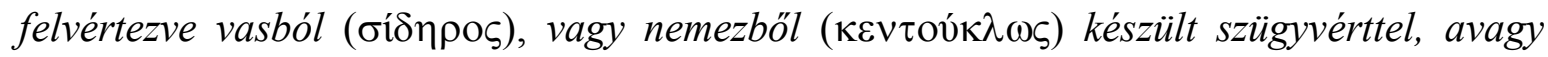
avar mintára legyen takarva szügyük és nyakuk, különösen az elsö harcvonalba állitottaké” (MAURIKIOS I. 2, 6. ford. SZÁDECZKY-KARDOSS 1998, 80).

Szádeczky-Kardoss Samu úgy véli, hogy másolási hiba kapcsán került bele a szövegbe a második „vagy” (fordításban avagy). Tehát a forrásban található „,vasból vagy nemezböl készült szügyvért” is az avarok lovaira vonatkozik. Ezt a véleményt támasztja alá Maurikios másik passzusa (SZÁDECZKY-KARDOSS 1998, 81):

„De nemcsak ők maguk viselnek fegyvert, hanem az elökelök lovainak szügyét is vas vagy nemez fedi” (MAURIKIOS XI. 2, 7. ford. SZÁDECZKY-KARDOSS 1998, 83).

Theodóros Synkellos is utal a lovak páncélzatára, melyet $\theta \omega ́ \rho \alpha \xi$ terminussal jelöl. Ez a terminus nem vonatkozik konkrét páncéltípusra, lehetett lemezes- és gyürüspáncél is.

A frank-avar háborúk korszakára vonatkozó írott források nem említik a lovak vértezetét. Az avar hadsereg lovainak vértezetére utaló leletek még nem kerültek elő. ${ }^{277}$

\section{1. 11. Kérdéses fegyverterminusok}

Az avarok fegyverzetére vonatkozólag egy kifejezés található, melyböl nem lehet pontosan meghatározni konkrét fegyvertípust: ßé̉os (THEODÓROS SYNKELLOS XIX 305, 37-306, 12; GEÓRGIOS PISIDÉS 197-225).

Mint azt már a nyilakról szóló alfejezetben jeleztem, a $\beta \varepsilon ́ \lambda o \varsigma$ terminusnak nem egyértelmű a jelentése, és ebben a két esetben a szövegkörnyezetből sem lehet egyértelmüen eldönteni, hogy nyílra vagy dobódárdára vonatkozhatott ez a kifejezés. Geórgios Pisidés Konstantinápoly ostromakor leírja, hogy mely fegyvereket vetettek be az

${ }^{276}$ Mindkét ábrázoláson látható pajzsok formája kerek, és az egyiken pajzsdudor látható (MESTERHÁZY 1968, 245-247; BÓNA 1984, 82. kép).

${ }^{277}$ Belsö-ázsiai türk kori ábrázolásokon láthatók a lovak szügy-, nyak- és fejvértjei [10., 11. kép] (DoszimBajeVA-Golden-OsZAVA 2013, 12; KuBAREV-KubAREV-BAJÁr 2013, 614). 
avarok, a felsorolásban kürtök és a kardok között említi meg a $\beta \varepsilon ́ \lambda o \varsigma$ terminust (GEÓRGIOS PISIDÉS 197-225), mely ugyanúgy vonatkozhat dobódárdára és nyílra is. Theodóros Synkellos szintén Konstantinápoly ostrománál emlékezik meg arról, hogy mely fegyvereket vetettek be az avarok, szerinte a fal teljes hosszában használták a $\beta \varepsilon ́ \lambda o s-t$ és a parittyát (THEODÓROS SYNKELLOS XIX 305, 37-306, 12), mely egyformán vonatkozhatott dobódárdára és nyílra is. Figyelembe véve, hogy az egyik forrás müfaja költemény, a másik pedig szentbeszéd, maguktól a szerzőktől sem várható el, hogy teljesen reális képet fessenek a Konstantinápolyt ostromló sereg fegyverzetéről.

\section{2. Harcmodor}

$\mathrm{Az}$ írott források többnyire, más nomád népekhez hasonlóan, negatív színben tüntetik fel az avar harcosokat a harcmodoruk kapcsán. ${ }^{278}$ Geórgios Pisidés és Theodóros Synkellos ravasz, gaz rókának, gonosz vadállatnak, fondorlatos, cselszövő kígyónak nevezi a 623-ban a bizánciakkal szemben meglepetésszerü támadást intéző nomád népet (GEÓRGIOS PISIDÉS 113-114; THEODÓROS SYNKELlOS 301, 24-302, 8. vö. SZÁDECZKY-KARDOSS 1998, 166, 176). Szintén Theodóros Synkellos, valamint Nikephoros Patriarcha hangsúlyozza, hogy az avarok megbízhatatlanok, szerződésszegők, hitszegő kutyafajzatok (THEODóROS SYNKELLOS 301, 40-302, 21. vö. SZÁDECZKY-KARDOSS 1998, 169). Hasonlóan jellemzi az avarokat Maurikios is: szerinte „,komiszok és kétszínüek.” A hadászatban jártas császár emellett hangsúlyozza, hogy a férfiak a harcászatban nagyon jártasak, ez a fö tevékenységük, máshoz nem értenek ${ }^{279}$ (MAURIKIOS XI. 2, 3. vö. SzÁdECZKY-KARDOSS 1998, 83). Theodóros Synkellos is erre utal azzal, hogy az avarok élete a háború (ßíos ó

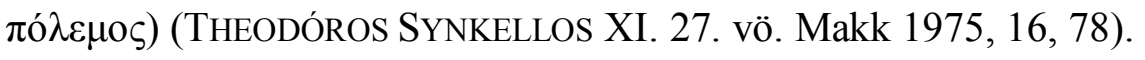

Az avar hadsereg hadjáratra, csatára való felkészülése kapcsán a gyakorlásra, fegyelemre, felderítésre, folyón történő átkelésre és az utánpótlásra vonatkozó adatok figyelhetők meg az írott forrásokban. A csaták leírásaiban viszonylag jelentős számú utalást találunk a hadrendjükre, hadseregük létszámára vonatkozólag. Valamint többféle típusa figyelhető meg a katonai jeladásoknak és a pszichológiai hadviselésnek. A

\footnotetext{
${ }^{278}$ Lásd a hun fejezet harcmodorral foglalkozó részének bevezető passzusát.

${ }^{279}$ Hasonló jellemzést ad Szema-Kien a hiung-nukról, úgy véli, hogy közülük minden férfi ért az ijkészítéshez, és mindegyikük páncélos lovas harcos (SzEMA-KIEN vö. Du Yaxiong-Horváth 1997, 17). Amint a hunoknál láttuk, a skandináv saga szerint minden 12 évesnél idősebb hun hadba vonult (ToLKIEN 1960, 52). Sinor Dénes ezzel kapcsolatban úgy vélte a források alapján, hogy a nomád népeknél minden férfi egyben harcos is volt. Erre utalhat az is, hogy a török és a mongol nyelvekben nem figyelhető meg külön szó a férfira, a „harcos” terminust alkalmazták háborúban és békében is (SINOR 1981, 135).
} 
hadjáratok során létesített táborok kialakításáról, védelméről viszont csak kevés információ áll a rendelkezésünkre. A hadsereg egységei közül az elővédről, a könnyü- és nehézfegyverzetü lovasságról és a tartalékhaderőről számolnak be a kútfök. Kevés, bizonytalan adatunk van az avarok gyalogságáról és a kagán testőrségéről.

\section{2. 1. Hadjáratra, csatára történő felkészülés}

A hadjáratra, csatára történő felkészülés esetében az avar hadseregnél megfigyelhető a gyakorlás, a fegyelem, a felderítés, valamint számos változata ismert a folyón történő átkelésnek, és az utánpótlás kérdését is többféleképpen oldották meg az avarok.

\section{2. 1. 1. Gyakorlás}

Mint már a hun harcmodorral foglalkozó fejezetben utaltam rá, a nomád népek esetében is fontos szerepet játszott a különbözö taktikai elemek begyakorlása. Természetesen az avaroknál sem volt másként: Maurikios röviden utal arra, hogy nagy gondot fordítanak a lóháton történő nyilazás gyakorlására is. ${ }^{280}$

Emellett a bizánci szerző beszámol a „szkíták” vadászati szokásairól is, és kiemeli, hogy ez lényegében hadigyakorlásnak is tekinthető. Több öt- vagy tízfős egységre oszlanak, és fó fegyverzetük az íj és a nyíl. A kis létszámú egységek a vadállattól megfelelő távolságban helyezkednek, hajtják a vadat, és le is nyilazzák. A forrás hangsúlyozza, hogy jó gyakorlást biztosít ez a „szkíták” számára, ezzel párhuzamosan azonban arra is felhívja a figyelmet, hogy közben veszélybe sodródhatnak a fiatal (gyakorlatlan) harcosok, és céltévesztés is előfordulhat ezeken az eseményeken, vagyis fennállhatott annak a veszélye, hogy a vad üldözése közben a több kisebb csoport harcosai esetleg egymást találhatták el (MAURIKIOS XII. 10, 33. vö. SzÁDECZKY-KARDOSS 1998, 84). Más nomád népeknél is megfigyelhető, hogy a vadászatnak jelentős szerepe volt a haditaktikai elemek gyakorlásában is. ${ }^{281}$

\footnotetext{
${ }^{280}$ Lásd bővebben a hunok harcmodorával foglalkozó fejezet gyakorlás alfejezetét.

${ }^{281}$ Például a mongoloknál írták le, hogy vadászat közben gyakorolják az íj használatát (Plano Carpini IV. 10. vö. GYÖRFFY 1965, 68). Rubruk szerint a mongolok a vadászatok alkalmával körbeveszik az adott területet, ahol vadállatok tartózkodnak, és ezt a kört fokozatosan szükítik, majd lenyilazzák az állatokat (Rubruk V. 4. vö. GYÖRFFY 1965, 127).
} 


\section{2. 1. 2. Fegyelem}

Ahhoz, hogy a csaták közben a különböző taktikai elemeket sikeresen végre tudják hajtani a több egységből felépülő nomád hadseregek - hasonlóan más népekhez - a gyakorlás mellett fontos szempont a fegyelem betartása. Az avarok esetében Maurikios hadászati munkájában találunk erre vonatkozóan információkat. A hadászatban jártas császár utal arra, hogy az avar hadsereget a félelem tartja egyben, és vezetőiktől esetleges hibák elkövetése esetén súlyos retorziókra számíthattak (MAURIKIOS XI. 2, 3. vö. SZÁDECZKYKARDOSS 1998, 83). Ez természetesen nem tekinthető nomád specifikumnak, más népeknél is megfigyelhető ez a jelenség. Maurikios általános sztereotipikus kijelentése mellett más nomád népeknél részletesebb információkat találunk arra vonatkozólag, milyen büntetések jártak a parancsmegtagadás és a csatában történő megfutamodás miatt. $^{282}$

\section{2. 1. 3. Felderítés}

Fontos szempont volt egy-egy hadjárat megindítása előtt és a hadjáratok közben is tájékozódni a megtámadni készülő területek földrajzi helyzetéről és népességéről stb., valamint az ellenfél hadseregének felépítéséről, létszámáról, hadmozdulatairól. Mint már azt a hunok esetében jeleztem, a felderítő egységeket két nagy csoportra lehet elkülöníteni a türk és a mongol hadseregben: rendelkeztek egy olyan egységgel, mely vagy még a hadjárat megindítása előtt feltérképezte a megtámadni készülő területeket, vagy legalábbis a hadjáratok közben, de a felvonuló hadseregüktől jóval távolabbi területeket derített fel. ${ }^{283}$ A másik típusú felderítő egységük pedig a közvetlenül a hadseregük közelében az ellenség csapatmozgását, manővereit figyelte. Valószínűsíthető, hogy az avaroknál is jelen lehetett mindkét típusú felderítő egység, vagyis a távol fekvő területeket és a közvetlen környezetet fürkésző hadiegységek. A Bizánc elleni sikeres hadjáratok egyik előfeltétele volt, hogy az avaroknak széles körü ismeretei legyenek a birodalom földrajzi viszonyairól, népességéről, településeiröl stb. Maurikios azonban ebben a témában is csak általánosságban nyilatkozik,

\footnotetext{
${ }^{282}$ A hiung-nuknál Szema-Kien munkájában lelhető fel egy történet, mely Mao-tun hatalomra jutását örökíti meg. Az auktor szerint, aki nem teljesítette a parancsát, azokat mind megölette (például azokat, akik nem löttek a legjobb lovára, kedvenc feleségére, apjára, a hiung-nu sanjüre) (SZEMA-KIEN vö. Du YaxiongHorváth 1997, 33). A mongolok esetében latin nyelvü, muszlim és belső források utalnak erre a jelenségre. Például Plano Carpini szerint a csatában megfutamodókat kivégzéssel büntetik (Plano Carpini VI. 3. vö. GYÖRFFY 1965, 79; MAY 2007, 47-50, 89-90, 106, 138).

${ }^{283}$ A nomád népek hadseregének felderítéséről lásd részletesebben a hun fejezet felderítésről szóló részében.
} 
miszerint „ügyesen kilesik” a megfelelő helyzetet, és azt ki is használják (MAURIKIOS XI. 2, 5. vö. SZÁDECZKY-KARDOSS 1998, 83). ${ }^{284}$

$\mathrm{Az}$ avarok is igénybe vehettek olyan, az adott területen jól tájékozódni képes embereket, akik a kívánt célpontig kalauzolták seregüket. Erre jó példa, hogy az avarok a térséget jól ismerő ,útikalauzokat” vettek igénybe, akik először a Sirmium ellen vonuló nomád hadsereget vezették az egykor gepida fennhatóság alatt is állt város ellen (SUDA vö. SZÁDECZKY-KARDOSS 1998, 37). ${ }^{285}$

Az információszerzésnek egyik fontos eleme volt, hogy a felderítők „nyelveket” fogtak, és információkat szereztek tőlük. Erröl a 592-ben Tzurullonig (ma Çorlu, Törökország) előrenyomuló avar hadseregnél két ízben is beszámol Theophylaktos Simokattés munkájában. Az avar kagán fogságába elöször bizánci felderítők kerültek, másodszor pedig a bizánci császár testőre. Az első esetben azonban a bizánci felderítők kínzások ellenére sem valós információkat osztottak meg az avar kagánnal. Az utóbbi esetben pedig hangsúlyozandó, hogy a bizánciak cseléről volt szó, és a „foglyul ejtett nyelv," vagyis a császár testőre szándékosan esett avar fogságba, és tudatosan vezette félre az avar kagánt (THEOPHYLAKTOS SIMOKATTÉS VI. 5. 2-3, 11-16. vö. Olajos 2012, 220222). ${ }^{286}$

\section{2. 1. 4. A folyón történő átkelés}

Amint már a hunok esetében utaltam arra, hogy a nomád népeknél számos módja ismert a forrásokból a folyón való átkelésnek. Az avaroknál föként a bizánci kútfők térnek ki többször erre a problémakörre. Ez a nomád nép is többféle módon oldotta meg a folyón történő átkelést. Megfigyelhető néhány esetben, hogy egyszerűen átúsztatnak a folyón a lovaikkal, vagy pedig bevárva a telet a befagyott folyón kelnek át. Emellett az alávetett népeikkel vagy pedig szövetségeseikkel építtettek átkelésre alkalmas eszközöket. Saját maguk is készíthettek az e célra megfelelő alkalmatosságokat. Néhány esetben a források

\footnotetext{
${ }^{284}$ Erre szolgáltathat példát Singidunum (ma Belgrád, Szerbia) városának bevétele. Valószínüleg az avarok rendelkeztek információkkal arra vonatkozóan, hogy a város nem volt felkészülve egy esetleges támadásra, és az őszi betakarítással voltak elfoglalva (THEOPHYLAKTOS SIMOKATTÉs I. 4, 1-2. vö. Olajos 2012, 78).

${ }^{285}$ A Suda lexikonban található Hégemón szó alatt található híradás esetében nem nevezik meg konkrétan az avarokat, Szádeczky-Kardoss Samu azonban feltételezi, hogy ez a történet összeköthető az avarok első, Sirmium elleni támadásával, amikor még e nomád nép számára ismeretlen volt a Száva vidéke. Továbbá nem kizárt, hogy ez a részlet Menandros Protéktór munkájából származhat (SZÁDECZKY-KARDOsS 1998, 37).

${ }^{286}$ Priskos hadvezére egy állevelet vitt, amiben az állt, hogy Priskos tartson ki Tzurullonban, mert rövidesen érkezik a jelentős erőt képviselő felmentő sereg. Az avar kagán - Theophylaktos Simokattés szerint - ennek hatására vonult vissza seregével bizánci területekröl (THEOPHYLAKTOS SiMOKATTÉs VI. 5, 11-16. vö. Olajos 2012, 222).
} 
bár megemlékeznek a folyón történő átkelésről, nem részletezik azt, hogy ez hogyan történt (MENANDros ProtéKTór 456, 12-458, 30. vö. SzÁdECZKY-KARDOSS 1998, 37).

Corippus írja munkájában, hogy az avar követek saját elmondásuk szerint a perzsa területek támadásakor a befagyott Eufráteszen keltek át (CORIPPUS III. 151-152, 231-401. vö. SZÁDECZKY-KARDOSS 1998, 29). ${ }^{287}$ Kisebb folyók esetében azonban valószínüleg nem bonyolították túl az átkelést, és egyszerűen átúsztattak a lovaikkal. ${ }^{288}$ Erre jó példát találunk Theophylaktos Simokattés munkájában, amikor 598 végén/599 elején az avarok a Iatroson átúsztattak a lovaikkal, és a rendezetlenül visszavonuló bizánciakat támadták meg (THEOPHYLAKTOS SimoKATTÉS VI. 14, 7. vö. Olajos 2012, 258).

Több alkalommal is olvasható a forrásokban, hogy az avarok a velük szövetséges népek segítségét vagy alávetett segédnépük szakértelmét vették igénybe a folyón történő átkelésben. A szövetséges népek közül a bizánciakról és a langobardokról vannak adataink.

Az avarok 578-ban Tiberios császár szövetségeseként támadták meg az al-dunai szlávokat, és a Dunán Baján seregét a rómaiak, azaz a bizánciak ,úgynevezett hosszú hajókon”, majd az akció végeztével a forrásból nehezen értelmezhető hajótípuson vitték vissza őket (MENANDros ProtéKTór 208, 11-210, 2. vö. SzÁdECZKY-KARdoss 1998, 46). A forrás tehát két különböző típusú hajóról emlékezik meg. Az egyik a hosszú hajó

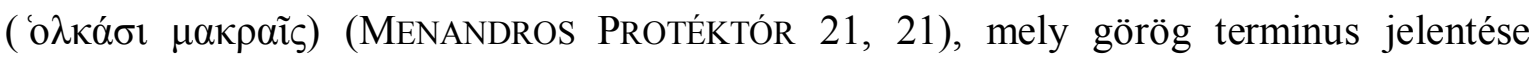
elsősorban hosszú teherhajóra utal (GYÖRKÖSY-KAPITÁNFFY-TEGYEY 1990, 724). A másik

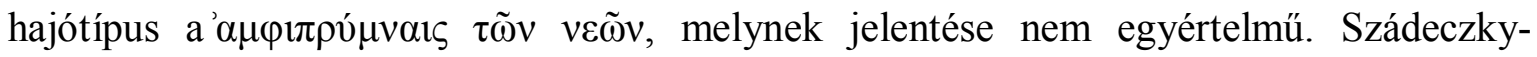
Kardoss két hátsó fedélzetünek, esetleg két kormánnyal rendelkezőnek fordította (SZÁDECZKY-KARDOSS 1998, 46). Blockley ezzel szemben dupla hajófarral rendelkező vízijármünek értelmezte ezt a kifejezést (BLOCKLEY 1985, 193). Az 579/580-as szlávok elleni sikeres hadivállalkozás után Zonaras ${ }^{289}$ és Ioannes Ephesinus együttesen emlékezik meg arról, hogy Sirmium elleni blokád kiépítésében az avarok bizánciakat is felhasználtak. ${ }^{290}$ A bizánci császártól - palota, fürdő létesítésére - kért építészek gerendából ácsolt, erős hidat hoztak létre a Száván (ZONARAS XIV. 11, 18 -19. vö.

\footnotetext{
${ }^{287} \mathrm{Az}$ erre vonatkozó nomád analógiákat lásd a hun fejezetben.

${ }^{288}$ Más nomád népekre vonatkozó adatokból egyértelmüen kitünik, hogy nagyobb folyók esetében ez az átkelési mód felettébb kockázatos volt, amivel veszélyeztethették a harcosok életét, fegyverzetük és egyéb eszközeik (például sátrak) épségét. A nagyobb folyókon ily módon történő átkelés legtöbbször kudarcba fulladt, például a honfoglaló magyarok és a krími tatárok esetében értesülünk arról, hogy elsodorta öket a Duna (FELFÖLDI 2004, 76).

${ }^{289}$ Ephraim - Zonaras munkáját felhasználva - utal erre az eseményre (SZÁDECZKY-KARDOSS 1998, 48).

${ }^{290}$ Mindkét forrás kitér arra, hogy az avar kagán építészeket kért a bizánci császártól azért, hogy számára palotát és fürdőt építsenek, majd ezt követően kényszeríttette öket arra, hogy hidat létesítsenek (SZÁDECZKYKARDOSS 1998, 48-49).
} 
SZÁDECZKY-KARDOSS 1998, 48; Pseudo-Ephraem VI. 24. vö. KMOSKÓ 2004, 136). ${ }^{291}$ A rómaiak által épített híd szerkezetéről kiegészítő információt találunk a Suda lexikonban, amelyből kiderül, hogy az avar kagán a bizánciakkal hullámtörővel ellátott hidat verettetett (SUDA vö. SZÁDECZKY-KARDOSS 1998, 49). ${ }^{292}$

Az avarokkal szövetséges langobardokra is találunk arra vonatkozóan utalást, hogy az avar hadsereg vízi szállítását segíttették. Paulus Diaconus történeti munkájából kiderül, hogy Agilulf langobard király hajóépítő mestereket küldött az avar kagánnak, kiknek segítségével Trákiában egy szigetet elfoglaltak az avarok (PAULUS DiACONUS IV. 20. vö. Galamb 2012, 132). ${ }^{293}$

$\mathrm{Az}$ alávetett segédnépek közül a szlávokról több adatot is ismerünk az írott forrásokból, mely szerint számos alkalommal aktívan segítették az avar hadsereg folyón történő átkelését. Az avarok 592-es, Bizánci Birodalom elleni támadása során a Száván és a Dunán történő átkeléskor a szlávok által épített csónakokat vett igénybe (TheOphylaktos Simokattés VI. 3, 9; 4, 1. vö. Olajos 2012, 218). A forrásból kiderül, hogy ez az alávetett segédnép nagy számban vett részt az építőmunkában, és jelentős mennyiségü csónakot épített. Konstantinápoly 626-os ostroma kapcsán a Húsvéti krónikában és Theodóros Synkellos munkájában találunk adatokat arra, hogy a szlávok ekkor is fatörzscsónakokat készítettek. Ezeknek kétféle szerepük volt, egyrészt a csónakok segítségével igyekeztek kapcsolatot teremteni a perzsákkal, másrészt a tenger felől csónakok segítségével vettek részt az ostromban a szlávok. A szlávok mindkét célkitüzése teljes kudarcba fulladt, a bizánci flottával szemben esélytelenek voltak ezek csónakok (Chronicon Paschale 722, 14-724, 7; 724, 9-725, 15; TheodóRos SynKellos XXII. 307, 8-17, XXIII. 307, 37-40. vö. SzÁDECZKY-KARDOSS 1998, 185, 187). A két utóbbi

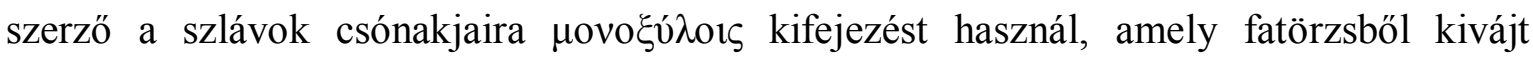
egyszerü 'csónak' jelentéssel bír. Theophylaktos viszont egy másik terminust használ: 'akátıov (THEOPHYLAKTOS SiMOKATTÉS VI. 3, 9), mely általánosságban kis hajót,

\footnotetext{
${ }^{291}$ Az erre az időszakra fö forrásunk Menandros Protéktór, aki nem utal arra, hogy ezt a hidat bizánciak (is) építették volna fel (MENANDRos ProtéKTór 471, 25-476, 25. vö. SzÁDECZKY-KARDOSS 1998, 48-49).

${ }^{292}$ Ezek a hullámtörök a forrás szerint a háromszögletü alakú építmények voltak (SUDA vö. SZÁDECZKYKARDOSS 1998, 49). A háromszög alakú, elöre nyúló hullámtöröknek az volt a feladatuk, hogy a folyómederbe épített pilléreket védjék a folyó által szállított jégtöl, uszadékoktól.

${ }^{293}$ Arra vonatkozóan, hogy Trákiában mely szigetet foglaltak el az avarok langobard hajóácsok segítségével, más forrás nem utal. Szádeczky-Kardoss Samu feltételezi, hogy (bár nem Trákia területén található) esetleg a Viminacium (ma Stari Kostolac, Szerbia) előtt fekvő Duna-szigetről lehet szó, mely 599-ben Priskos sikeres avarok elleni hadjáratában kiindulópontul szolgált. Szádeczky-Kardoss szerint Priskos hadjárata után az avarok a sziget elfoglalásával egy újabb, ilyen jellegü támadásnak akarták volna elejét venni (SZÁDECZKYKARDOSS 1998, 135). Ez utóbbi feltételezett eseményről azonban nem áll rendelkezésünkre forrás.
} 
bárkát jelent (GYÖRKÖSY-KAPITÁNFFY-TEGYEY 1990, 40). Valószínüsíthető, hogy ez esetben is monoxülonokról lehet szó (OLAJOS 2012, 218).

A szövetségesek és az alávetett segédnépek mellett azonban arról is vannak adataink, hogy az avarok saját maguk is képesek voltak vízi eszközöket gyártani. Maurikios hadászati munkájában is találunk erre vonatkozóan adatot: a hadászatban jártas császár a „szkíta” módra történő hídépítésre hívja fel a figyelmet (MAURIKIOS XI. 4, 1617. vö. SzÁdECZKY-KARdoss 1998, 84). Szádeczky-Kardoss Samu úgy véli, hogy a bizánciak az avarok építési technikáját Sirmium 579-582-es ostroma közben figyelhették meg (SZÁDECZKY-KARDOSS 1998, 84). Sirmium blokád alá helyezése kapcsán Menandros Protéktór munkájából kiderül, hogy az avarok a Száván történő átkeléshez és a város lezárásához hidat és hajókat alkalmaztak. Menandros kiemeli, hogy ennek a hídnak ( $\gamma \varepsilon ́ \varphi v \rho \alpha$ : MENANDROS PROTÉKTÓR 25. 1, 12) az építésében az avarok aktívan részt vettek (Menandros ProtéKtór 471, 25-476, 25. vö. SzÁdeCZKY-Kardoss 1998, 47-48). Az azonban sem Maurikios, sem Menandros munkájából nem derül ki, hogy a „szkíta módra” épített hídnak milyen sajátosságai voltak, és miben különbözött a bizánciakétól. ${ }^{294}$ Menandros munkájában a hídépítés mellett hajókról is említést tesz. Az auktor egyrészt leírja, hogy Felső-Pannonia területéröl nagyszámú masszív vízi járművet ( $\pi \lambda$ oĩov: MENANDROS PROTÉKTÓR 25. 1, 18) gyüjtöttek össze az avarok, másrészről hosszú katonai

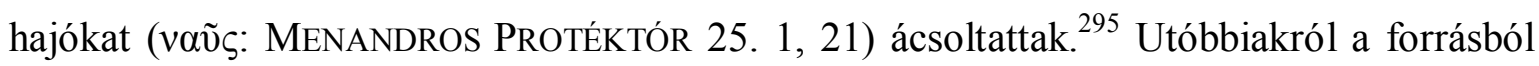
kiderül, hogy ezek a vízi alkalmatosságok evezős hajók voltak, a bizánci szerkezeteknél kezdetlegesebb felépítésüek (MENANDROs PROTÉKTÓR 471, 25-476, 25. vö. SZÁDECZKYKARDOSS 1998, 47). A kútfő nem nevezi meg konkrétan, hogy maguk az avarok vagy esetleg valamely segédnépük készítették ezeket a hajókat.

\section{2. 1. 5. Az utánpótlás kérdése}

A hadjáratokban részt vevő avar hadsereg is - a hunokhoz hasonlóan - többféleképpen oldotta meg az utánpótlás problémáját. Egyrészt a hadjáratok során zsákmányolásból

\footnotetext{
${ }^{294}$ A kínai források szerint a hiung-nu seregben voltak olyan speciális egységek, melyek értettek a hídveréshez. Lóbőrből készült tömlökböl állították össze ezeket a szerkezeteket, melyek a pontonhídakhoz hasonlóak voltak (KolLAUTZ-MiYAKAWA 1970, 43). Felmerülhet annak a lehetősége, hogy Maurikios is ehhez hasonló szerkezetre gondolhatott az avarok „szkíta módra” épített hídjai esetében. Azonban Sirmium ostromának leírásából inkább valós hídra kell gondolnunk. Mindenesetre mindkét szerzö, Maurikios és Menandros Protéktór a bizánciak által általánosan használt híd terminust, a $\gamma \varepsilon \dot{\varphi} \varphi v \rho \alpha-t$ alkalmazta az avarok által emelt hídra is (MAURIKIOS XI. 4, 17; MENANDros ProtéKTór 25. 1, 12)

${ }^{295}$ A forrásból nem lehet egyértelmüen eldönteni, hogy két különbözö hajótípust alkalmaztak az avarok az átkelésre, vagy pedig a Felső-Pannoniából összegyüjtött hajókat alakították át katonai járművekké.
} 
biztosíthatták az utánpótlásuk egy részét. Például 578-ban az al-dunai szlávok ellen vezetett hadjárat során Menandros szerint szláv falvakat fosztogattak az avarok (Menandros ProtéKtór 208, 11-210, 2. vö. SzÁdeczKY-KARdoss 1998, 46). Paulus Diaconus munkájából kiderül, hogy 602/603-ban az avarok szláv segédcsapataikkal és a langobardokkal szövetségben Istriában (Istra, Horvátország) raboltak (PAULUS DIACONUS IV. 24. vö. Galamb 2012, 134). Másrészröl békekötések alkalmával is biztosíthatták a maguk számára az ellátmányt. Erre példa a Kárpát-medencei honfoglalásukat megelőzően a frankokkal történő második összecsapásuk, amikor I. Sigibert (561-575) frank király is az avarok fogságába került. A frankok uralkodójukat ajándékok fejében kapták vissza (Gregorius TURONENSIS IV. 29. vö. Adamik-Mezei 2010, 292). Ugyan ezen esemény kapcsán Menandros munkájából kiderül, hogy ezek az ajándékok föként élelmet jelentettek: liszt, hüvelyesek, juh, szarvasmarha (MENANDROS PROTÉKTóR 454, 14-22. vö. SZÁDECZKY-KARDOSS 1998, 32). Ezenkívül a számukra szükséges dolgokat is magukkal vihették. Ide tartoznak a tartalék lovak, melyek Maurikios szerint táplálékul szolgáltak az avaroknak, és nagyobb létszámúnak tủnt tőlük a hadsereg. Míg ez utóbbira számos példát találunk a nomád népek körében, ${ }^{296}$ addig a ló fogyasztása nem nagyon volt jellemző körükben, csak kismértékben figyelhető meg náluk ez a jelenség. U. Köhalmi Katalin hangsúlyozza, hogy a steppei nomád népek ritkán esznek lovat, akkor is leginkább kultikus okokból (U. KÖHALMi 1972, 18; TOMKA 1997, 89; BARTOSIEWICZ 2009, 78-79). Tehát inkább tartalék lovakként funkcionálhattak a hadjáratok során. ${ }^{297}$ A tartalék lovakon kívül még egyéb dolgok szállítását is meg kellett oldaniuk az avaroknak, például fegyverek, sátrak, ostromeszközök egyes alkatrészei. Maurikios hadászati munkájában megemlíti az erre (is) vonatkozó málhákat, melyeket a csata helyszínétől két mérföldre megfelelő őrizet mellett helyeztek el az avarok (MAURIKIOS XI. 2, 9, 13-14. vö. SzÁDECZKY-KARDOSS 1998, 84). Ezekre a málhákra utalhatnak a hadjáratok során több alkalommal megemlített avar szekerek $^{298}$ is (CORIPPUS III. 231-401; THEODÓROS SYNKELlOS XIII. 303, 10. vö.

\footnotetext{
${ }^{296}$ Lásd a hun fejezet utánpótlással foglalkozó alfejezetét.

${ }^{297}$ Maurikios szerint a csaták alkalmával a tartalék lovakat a málhákkal együtt a csata színhelyétől 1 vagy 2 mérföldre helyezték el (MAURIKIOS XI. 2, 13. vö. SZÁDECZKY-KARDOSS 1998, 83).

${ }^{298} \mathrm{Az}$ avar szekerekre Theophylaktos Simokattés és Theodóros Synkellos a ọ́ $\mu \alpha \xi \alpha$ kifejezést használja (Theophylaktos Simokattés VII. 11, 7; VII. 13, 4; Theodóros Synkellos XIII. 303, 26-27), mely 'négykerekü szekér' jelentéssel bír (GYÖRKÖSY-KAPITÁNFFY-TEGYEY 1990, 56). Corippus pedig a plaustra terminust alkalmazza (CORIPPUS III 288), amelynek a jelentése 'társzekér, teherszekér' (FINÁLY 1884, 1509). Theophylaktos Simokattés az avarok szláv segédnépei esetében is az általa az avarok szekereire használt ‘́ $\mu \alpha \xi \alpha$ terminust alkalmazza (THeOPHYLAKTOS SimoKATTÉs VII. 2, 4). Szíriai Mihály az avarok szláv alávetett népe esetében szintén „erős szekereikröl” számol be (Michael Syrus X. 21. vö. SZÁDECZKYKARDOSS 1998, 61). Az avar szekértípusokkal legutóbb Kürti Béla foglalkozott. Egy a frank-avar háborúk időszakára vonatkozó forrást vett górcső alá. Az Annales Nordhumbrani 795. évi bejegyzése szerint Nagy
} 
SZÁDECZKY-KARDOSS 1998, 29, 176; THEOPHYLAKTOS SimOKATtÉS VII. 11, 7; VII. 13, 4. vö. Olajos 2012, 254, 256). ${ }^{299}$ Feltételezhető továbbá - bár az írott forrásokban erre csak egy adatot találunk -, hogy ha szövetségesekkel indítottak hadjáratot, akkor az avar hadsereg ellátásáról a szövetséges felük (is) gondoskodhatott. ${ }^{300} 567$-ben a gepidák ellen a langobardokkal kötött szövetség értelmében a teljes gepida fennhatóság alá eső területek megszerzése mellett a langobardok állatállományának 1/10-e az avarokat illette meg (MENANdRos ProtéKtór 454, 32-456, 5. vö. SZÁdECZKY-KARdoss 1998, 32).

\section{2. 2. A csaták közbeni jelenségek}

Az avaroknál néhány adatból következtethetünk a csaták megkezdésének időpontjára is. Maurikios Startegicon címü munkájában azt hangsúlyozza, hogy elsősorban kikémlelve a legkedvezőbb helyzetet rajtaütésszerüen támadnak, és már éjszaka csatarendbe állítják a seregüket az avarok (MAURIKIOS XI. 2, 5, 10. vö. SZÁdECZKY-KARDOSS 1998, 83). Valamint szintén Maurikios emlékezik meg arról, hogy Herakleia környékén a bizánciakat éjszaka támadták meg az avarok (MAURIKIOS IX. 2, 2-3. vö. SZÁDECZKY-KARDOSS 1998, 77). Ezzel párhuzamosan azonban az is megfigyelhető a forrásokban, hogy általános középkori szokás szerint némely esetben az avarok is előre megegyeztek az ellenféllel a

Károly elpusztította a „hunokat”, és onnan aranyat, ezüstöt és értékes selyempalástokat zsákmányolt, melyeket 15 darab 4-4 ökör által vontatott szekereken szállított el. Kürti Béla feltételezi, hogy a gazdag zsákmány mellett a forrás által említett szekerek is a kagáni székhelyről származtak. Véleménye szerint az avar kagáni háztartás és a kincstár tárgyait ezeken a szekereken tárolhatták, mint ahogy erre a jelenségre több analógiát hozott fel a nomád népek köréből. Úgy véli, hogy az avarok által használt kocsi alapja egy tengely, melyre egymással párhuzamosan két rudat helyeztek, s ezek közé fogták a vontató állatot. A tengely fölött alakították ki a kocsitestet. Kürti szerint ezt a típust keletről hozhatták magukkal az avarok (KÜRTI 2003, 3339). Megjegyzendő azonban, hogy bár több forrás is megemlékezik erről az eseményről, a többi auktor nem említi meg ezeket a szekereket. Maga az angol krónikás ezt az eseményt nem Erich friauli hercegnek tulajdonítja, hanem Nagy Károlynak (SZÁDECZKY-KARDOss 1998, 286-287). A nomád népeknél a szekerek használata általános jelenségnek tekinthető. Már a hiung-nuknál megfigyelhető a használatuk. A kínai források szerint a hiung-nuk szekereit marhák, tevék vagy lovak húzták, ezeken belül is elkülöníthető az a típus, melyet hat ló húzott (KollaUTZ-MiYAKAWA 1970, 43). A szekerek és különböző szekértípusok megfigyelhetők még a türköknél és a mongoloknál is. Erről bővebben lásd KÜRTI 2003. A belső-ázsiai türk kori ábrázolásokon föként kétkereküek ezek a szekerek, és két rúd közé fogták az igavonó állatot (BABAJAROV-UMIROV-TASAGIL-NOVOZSENOV 2013, 134-140).

299 Arra vonatkozóan, hogy az avarok kiválóan megoldották az utánpótlás kérdését bizánci területeken, jó példát találunk Theophylaktos Simokattés munkájában, amelyböl kiderül, Tomea városánál az avar kagán felajánlotta Priskosnak, ellátja a bizánci sereget élelemmel, ,hogy ne éhezzenek a keresztények legnagyobb ünnepük, a közelgő nagypéntek és húsvét idején”. Az avar kagán ,élelemmel megrakott szekereket küldött” a bizánci seregnek (THEOPHYLAKTOS SiMOKATTÉS VII. 13, 4. vö. Olajos 2012, 256). Az avar kagán szokatlan felajánlásának értékelésével kapcsolatban lásd OLAJOS 1977, 3-12; OLAJOS 2012, 256.

300 Például ez feltételezhető az 578-ban Bizánccal szövetségben az al-dunai szlávok ellenében vezetett hadjárat során is (MENANDROS PROTÉKTÓR 208, 11-210, 2. vö. SzÁDECZKY-KARDOSs 1998, 46) vagy pedig 663 és 668 közötti esemény kapcsán, amikor az avarok Grimuald langobard királlyal szövetségben támadták meg Friaulban, a Grimuald ellen fellázadó Lupust (PAUlus DiACONUS V. 18-21. vö. Galamb 2012, 161162). 
csata időpontjában. Erre jó példa Priskos 599-es avarok ellen vezetett hadjáratának negyedik összecsapása, amikor is a két haderő meghatározta az ütközet időpontját (THEOPHYLAKTOS SiMOKATTÉS VIII. 3, 9. vö. Olajos 2012, 271). ${ }^{301}$

Csakúgy, mint más nomád és nem nomád nép esetében, az avarok is bevetettek különböző cseleket a győzelem érdekében. Maurikios avar sajátosságnak tartja a cselvetést (Maurikios XI. 2, 5. vö. SzÁdeCZKY-Kardoss 1998, 83). Menandros Protéktór töredékesen fennmaradt munkájából kiderül, hogy a Sirmium ellen vonuló avarok 579/580 táján a bizánciak figyelmét azzal próbálták elterelni, hogy mint korábban, most is a szlávok ellen vonulnak (MENANDRos ProtéKTóR 471, 25-476, 25. vö. SzÁdECZKY-KARdOSS 1998, 47). Egy kései forrásból, Bíborbanszületett Konstantin De administrando imperio címü munkájából arról értesülünk, hogy az avarok bizánci fegyvereket, zászlót és egyéb hadijelvényeket viselve tévesztették meg a bizánciakat, és így foglalták el Salonát (KÓNSTANTINOS PORPHYROGENNÉTOS 29, 1-53. vö. Moravcsik 2003, 123-125). ${ }^{302}$

A csaták leírásakor a hadsereg létszámára és a hadrendjére vonatkozóan több adatot találunk az írott forrásokban. Továbbá az avarok katonai jeladásainak és a pszichológiai hadviselésnek is többféle módját említik a kúfők. Valamint az avar hadsereg táborának a védelmére is található utalás az auktorok munkáiban.

\section{2. 2. 1. Hadrend, létszám}

Az avar hadsereg hadrendjére vonatkozólag Maurikios munkájában bukkanunk általános információkra. A bizánci császár szerint az avarok nem egy egységes hadrendbe szerveződnek, hanem több egységre oszlanak, melyek egymástól függetlenül hajtják végre a megadott taktikai elemeket. Emellett hangsúlyozza, hogy a csatasor mélysége bár nem egyenletes, ennek ellenére valószínűleg több sornyi mély lehetett, így mégis tömörnek tűnt az arcvonaluk. Ugyanerre a jelenségre utal Maurikios egy másik passzusában is. A Stratégikon szerzője azt is fontosnak tartja megemlíteni, hogy a „bizánci mintájú” hármas felosztással (jobb- és balszárny, középvéd) szemben az avarok több, különböző ezredbe, egységbe tömörülnek, mely felállásukkor egységes, egyetlen csatarendnek tünik.

\footnotetext{
${ }^{301}$ Theophylaktos megemlékezik arról, hogy Komentiolos 598/599 táján Iatros városánál (Bulgária) titokban követet küldött az avar kagánhoz. Az auktor Komentiolos e cselekedetét egyértelmüen árulásnak tekinti (TheOPHYLAKTOS SimoKATtÉS VII. 13, 9. vö. Olajos 2012, 257). Olajos Terézia azonban felveti azt a lehetőséget, hogy ebben az esetben a csata időpontjáról tárgyalhattak a felek (OLAJOS 1977, 5-6).

${ }^{302}$ Theophylaktos Simokattés arról számol be, hogy az avar hadsereg bizonyos egységei a bizánciakhoz pártoltak át. Olajos Terézia szerint feltételezhető, hogy ez csel lehetett, aminek a segítségével a császári csapatok harci szellemét akarták aláásni (OLAJOS 1977, 9; OLAJOS 2012, 277).
} 
Végeredményben ez az egységesnek látszó hadrend bomlik fel a támadásuk során több egységre, melyek különböző taktikai utasításokat hajtanak végre (MAURIKIOS II. 1, 6-7; XI. 2, 12-15. vö. SZÁDECZKY-KARDOSS 1998, 81, 83). Néhány esetben más bizánci szerzőnél konkrét csatajelentek kapcsán is megfigyelhető ez a rendszer. Priskos 599-es, sikeres avarok elleni hadjárata során az avarok különböző hadrendi szerveződéséről számol be Theophylaktos Simokattés az egyes csaták nál. Az első összecsapásukkor tizenöt egységből állt az avarok hadrendje, és az utolsó előtti csatában tizenkét csapategységre oszlott a hadseregük. Emellett szintén e hadjárat egyik csatájában Theophylaktos szerint egy az avarok egyetlen csatarendben álltak fel (THEOPHYLAKTOS SIMOKATTÉS VIII. 2, 10 4, 3. vö. Olajos 269-272). Ez utóbbira jó párhuzamként hozható fel Maurikios azon híradása, hogy az avar hadsereg felállásakor több csapategységük, ezredük egységes arcvonalnak tünik (MAURIKIOS XI. 2, 12. vö. SZÁDECZKY-KARDOSS 1998, 83). A Theophylaktosnál megörökített csatában azonban az avarok már az ütközet kezdetekor kedvezőtlen pozícióban voltak a bizánciakkal szemben. ${ }^{303}$ A forrás szerint Priskos ezt tökéletesen kihasználta, és elsöprő győzelmet aratott az avarok felett. Valószínüleg az avaroknak már nem volt idejük és lehetőségük külön csapaegységekre válni, és a különböző taktikai elemeiket végrehajtani.

A bizánci források néhány esetben megemlékeznek az avar haderő létszámáról is. Menandros Protéktór szerint a türkök elől menekülő avarok húszezren lehettek. Szintén ugyanezen szerző tájékoztat minket arról, hogy 578-ban a bizánciak hatvanezer páncélos avar lovast szállítottak át a Dunán (MENANDROs ProtéKTóR 452, 6-10; 208, 11-210, 2. vö. SZÁDECZKY-KARDOSS 1998, 14, 46). Theophylaktos pedig az avarok 592-es hadjárata esetében tesz említést az avarok 8 ezer fös elővédjéről (THEOPHYLAKTOS SIMOKATTÉS VI. 4, 11. vö. Olajos 2012, 220). Szintén az avarok elővédjének létszámára találunk adatot a Húsvéti krónikában a Konstantinápoly ostromára készülő avar sereg esetében: a forrás szerint harmincezer fős előcsapata volt a kagánnak (CHRONICON PASCHALE 717, 1-22. vö. SzÁDECZKY-KARDOSS 1998, 174). Geórgios Pisidés pedig az összes, Konstantinápolyt ostromló - beleértve a perzsákat is - sereg számáról ír: véleménye szerint az avarok segédnépeikkel és a perzsákkal együtt nyolcszor tízezren voltak (GEÓRGIOS PISIDÉS 197225. vö. SZÁDECZKY-KARDOSS 1998, 179).

Az avarokra vonatkozó létszámadatokkal Bóna István foglalkozott részletesebben, aki szerint a Menandrosnál található húszezer fős létszámadat hitelesnek tekinthető,

\footnotetext{
303 A bizánci auktor szerint a rómaiak hátszélben, magaslati pozícióból támadtak, és az avarokat egy mocsaras területre szorították (THEOPHYLAKTOS SiMOKATTÉS VIII. 3, 5-6. vö. Olajos 2012, 271).
} 
melyhez még a csatlakozott segédnépek haderejét is hozzá kell számítani. Ugyanezen bizánci szerző hatvanezres adatával szemben azonban tízes osztószámot alkalmazott, és Bóna szerint ebben az esetben hatezer fö lehet a történetileg hiteles adat. A Konstantinápoly ostromakor említett harmincezer fós sereget viszont reálisnak tartja a szerző. Ezen adatokból összességében Bóna István úgy véli, hogy az avar férfilakosság százezer főnél nagyobb lehetett, a páncélos nehézfegyverzetü lovasság számát pedig 10002000 före becsülte (BÓNA 1984, 320-321). Ahogy már a hunok esetében utaltam rá, a középkori forrásokban fellelhető létszámadatok eléggé megbízhatatlanok, így messzemenő következtetéseket nem lehet levonni az avar hadsereg létszámáról sem. Ami azonban kitűnik a fent említett forrásokból, hogy az avarok hadi szerveződése is tízes rendszeren alapult, ahogy más steppei török és mongol nyelvü népek, valamint más kultúrkörből származó (például bizánciak) népek esetében is a hadsereg századokból, ezredekből, tízezredekből épült fel (ZIMONYI 2004, 108; ZIMONYI 2005, 89).

\section{2. 2. 2. Katonai jeladások}

A hunoknál már korábban említett katonai jeladások közül az avaroknál mindhárom típus megfigyelhető: emberi hangot, hangszerekkel vagy egyéb tárgyakkal kiadott hangjelzést használtak, valamint a hadijelvények, eszközök felmutatásával adhattak egymásnak jelet. Maurikios is említést tesz erről a jelenségről a hadászati munkájában: a színlelt megfutamodás taktikájának alkalmazásakor a megfutamodók megbeszélt jelre fordulnak vissza, és ők is támadásba lendülnek az ekkora már megbomlott hadrendü ellenséggel szemben. A bizánci császár azonban nem utal arra, hogy mi is volt ez a jel (MAURIKIOS IV. 2. vö. SZÁDECZKY-KARDOSS 1998, 81).

A hangjelekre csak néhány forrásból következtethetünk, amelyekből kiderül, hogy az avarok csata és ostrom közben kiabáltak, lármáztak (THEODÓROS SYNKELLOS XXXII. 310, 37-311, 16; SUDA II. 355, 6-16; vö. SZÁDECZKY-KARDOSS 1998, 188, 40). Feltételezhetően ezek között lehetett olyan kiáltás, mely az avar csapategységek közötti katonai jelzések továbbítására szolgálhatott.

Az avar hadsereg katonai jeladásai közül az írott forrásokban leghangsúlyosabban a kürtök szerepe figyelhető meg. ${ }^{304}$ Corippus egy esetben említi az avarok kürtjeit a hadba

\footnotetext{
${ }^{304}$ Az avaroknál még feltételezhető, hogy esetleg még dobok hangjai is szolgálhattak hadi jelzésekre. A dobok azonban csak egyetlen egy esetben tűnnek fel a forrásokban, ahol konkrét szerepük is megőrződött. A Suda lexikon szerint az avar sereg hadmozdulataik során kiabálással és a dobok verésével zajt csapnak azért,
} 
vonulás jelképeként, valamint a kagán harci jelvényeként jelenik meg ez az eszköz munkájában (CORIPPUS III. 345-349. vö. SZÁDECZKY-KARDOSS 1998, 27). ${ }^{305}$ Az 584 nyarán vagy őszén Bizánc ellen vonuló avar hadseregnél Theophylaktos Simokattés történeti müvében két helyen is megfigyelhető, hogy a magasra emelt vagy a megszólaltatott harci kürt a hadba vonulást jelképezi (THEOPHYLAKTOS SIMOKATTÉS I. 4, 1; VII. 11, 9. vö. Olajos 2012, 78, 254). Konstantinápoly ostromakor Theodóros Synkellosnál pedig egyértelmüen a kürtök harc közbeni használata jelenik meg (THEOdóros SyNKELlos XXXII. 311, 3. vö. SZÁDECZKY-KARDOSS 1998, 188), ${ }^{306}$ melyek egyrészt az avar hadseregen belüli csapategységek közötti kommunikációra, katonai jelzések továbbítására szolgálhattak, emellett elrettenthették az ellenfelet. ${ }^{307}$

A hadijelvényekkel történő jeladásra kétféle adatot találunk a forrásokban. Maurikios császár hadászati munkájában arról ír, hogy az avar hadsereg lovassági lándzsái zászlóval voltak ellátva. A késő avar korra vonatkozóan a nagyszentmiklósi kincs 2. számú korsóján látható „győztes fejedelem” fegyverzetében is megfigyelhető a zászlóval ellátott lándzsa (BÁLINT 2004, 364). Az eurázsiai steppe nomád népeinél széles körben elterjedt volt a zászlóval, lobogóval ellátott lándzsák használata, ezeknek hadijelvény szerepük is volt (U. KÖHALMI 1972, 115, 123; GÖCKENJAN 2004, 62-70). Az ilyen típusú lándzsák mellett még ebbe a csoportba sorolható a korbács vagy ostor is. Az írott forrásokban az avarokra vonatkozólag a Chronicon Paschaléban található egy részlet, miszerint 623-ban a Hosszú Falaknál a kagán a korbácsával adott jelt ${ }^{308}$ a támadásra (CHRONICON PASCHALE 712, 9-713, 11. vö. SzÁDECZKY-KARDOSS 1998, 165). A Húsvéti krónika szerzője az

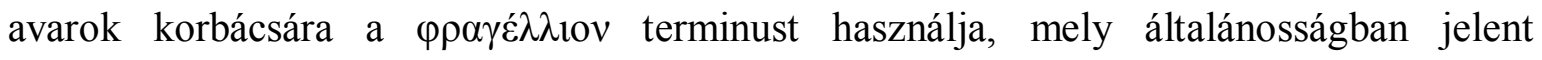
korbácsot, ostort (GYÖRKÖSY-KAPITÁNFFY-TEGYEY 1990, 1179), amelyből nem

hogy megfélemlítse, elrettentse az ellenfelet (SUDA II. 355, 6-16. vö. SZÁDECZKY-KARDOSS 1998, 188). Ennek ellenére nem zárható ki teljesen ez a szerepük az avarok kapcsán sem. A mongoloknál például egyértelmüen megfigyelhető a forrásokban, hogy dobokkal is adtak jelet a támadás megkezdésre és a visszavonulásra (OLBRICHT-PINKS 1980, 187, 190, GöCKENJAN 2004, 65-66).

${ }^{305}$ Például Al-Bakrinál a besenyők esetében úgy tűnik, hogy a kürt rangjelzésre is szolgált (GöCKENJANZIMONYI 2001, 165; GÖCKENJAN 2004, 67). A mongoloknál is az uralmi jelképek között szerepel ez az eszköz: a Kubiláj kán utasítására írt Fehér történet című munkában a kürt az uralmi jelképek között a zászló után a második helyen áll (SAGASTER 1976, 66).

${ }^{306}$ Konstantinápoly ostromának leírásakor még Geórgios Pisidés is megemlékezik az avarok kürtjéről, ő azonban csak felsorolja az avarok fegyverei, hadieszközei között, nem utal a használatuk okára, céljára (GEÓRGIOS PISIDÉS 197-225. vö. SZÁDECZKY-KARDOSS 1998, 179).

307 Theophylaktos Simokattés és Theodóros Synkellos a kürtre a $\sigma \alpha ́ \lambda \pi \imath \gamma \xi$ terminust alkalmazta (TheOPhYLAKTos Simokattés I. 4, 1; VII. 11, 9; THeOdóros SynKellos XXXII. 311,3.), mely 'csatakürt, trombita' jelentéssel bírt (GYÖRKÖSY-KAPITÁNFFY-TEGYEY 1990, 949). Corippus pedig a lituus terminust alkalmazza erre az eszközre (CORIPPUS III. 346), melyet szintén 'harcikürt' jelentésben használtak (FINÁLY 1884, 1149; GLARE 2000, 1037).

${ }^{308}$ Vegetius megemlíti az ostorokat is mint néma jeleket, amelyeket szerinte a barbárok használhattak (VEGETIUS II. 22. vö. Várady 1963, 791-792). 
következtethetünk az eszköz küllemére. ${ }^{309}$ A korbácsra utaló nyomok azonban a régészeti anyagban is felbukkannak. ${ }^{310}$ A steppei nomád népeknél ez a tárgy - a lovaglás folytán általános eszköznek tekinthető, már a szkítáktól megfigyelhető a használatuk (U. KÖHALMI $1972,67,92,122) .^{311}$

\section{2. 2. 3. Pszichológiai hadviselés}

A bizánci források néhány alkalommal kiemelik, hogy az avarok harc közben olyan félelmetes hangokat, zajokat hallattak, melyekkel megrémíthették az ellenséget. A Suda lexikon szerint az avar sereg hadmozdulatai során kiabálással és a dobok verésével ${ }^{312}$ zajt csapott azért, hogy megfélemlítse, elrettentse az ellenfelet. Az előbb említett forrásban olvasható az is, hogy az avarok támadásaik során farkasüvöltésszerü hangokat hallatnak (SUDA II. 355, 6-16. vö. SZÁdECZKY-KARDOSS 1998, 188). Ezenkívül Theodóros Synkellos Konstantinápoly ostromakor emlékezik meg arról, hogy az avarok ostromkor hatalmas csatakiáltásban törtek ki, és lármát csaptak, valamint a hadikürtjeiket fújták (TheOdóROS Synkellos XXXII. 310, 37-311, 16. vö. SzÁdECZKY-KARdosS 1998, 188). Ezek a harci kiabálások, csatazajok, dobverések sem tekinthetők specifikusan nomád jelenségnek. Természetesen más, letelepült népeknél is megfigyelhető mindez. A csatakiáltások kettős célt szolgálhattak: egyrészt ezzel próbálták az ellenfelet elrettenteni, megfélemlíteni, másrészt saját félelmüket is így leplezték, valamint így saját harci kedvüket is felszították. A középkor folyamán az is megfigyelhető, hogy a harcosok egy meghatározott szót kiáltottak ütemesen, ami alkalmas volt a csapat összefogására is. A

\footnotetext{
${ }^{309}$ U. Kőhalmi Katalin véleménye szerint a 6-8. században a korbácsnak kétféle típusa figyelhető meg: hosszú fonott szíjjal ellátott, rövid nyelü és rövid csapószíjjal rendelkező hosszabb nyelü forma (U. KöHALMI 1972, 122).

${ }^{310}$ A kunbábonyi sírban egy korbács sasfej alakú aranylemezborítása került elő (H. TóTH-HORVÁTH 1992, 36, 191-194).

311 Például a türkök lovagló ostora/korbácsa Menandros történeti munkájában figyelhető meg. A bizánci

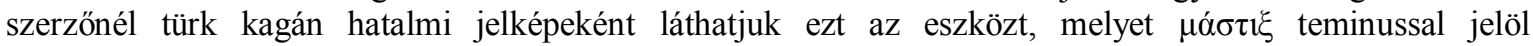
(MENANDROS PROTÉKTÓR 19. 1, 69). A Mongolok titkos történetében is megfigyelhető az ostor vagy korbács, ahol ez az eszköz a hatalom jelképeként tünik fel (SHM 125. vö. Rachewiltz 2006, 51-52). Ezenkívül mongol kori ábrázolásokon is szerepel a korbács (HOFFMANN 2005, 254, 272).

312 A mongoloknál is megfigyelhetö, hogy a dob dübörgése félelmet keltett az ellenfélben (SHM 106. vö Rachewiltz 2006, 37-38; GÖCKENJAN 2004, 65-66). Emellett ezeknek az eszközöknek a hangja jelezhette a harc kezdetét és a visszavonulást is (SHM 106. vö. Rachewiltz 2006, 37-38; GöCKENJAN 2004, 66). Több más eszközhöz hasonlóan a dob hatalmi jelképként is funkcionált. A Kubiláj parancsára írt Fehér történet szerint a dob az uralkodói jelképek között a negyedik helyen szerepelt (SAGASTER 1976, 59).
} 
közösen használt szó jelszóként is funkcionálhatott, ezzel lehetőséget teremtve arra, hogy elkülönüljenek az ellenségtől (HALMÁGYI 2007, 590). ${ }^{313}$

A pszichológiai hadviselés egyik formájaként értelmezhető az a jelenség is, hogy nagyobb létszámúnak próbálják feltüntetni a hadseregüket az ellenség szemében, mint amekkora valójában. Erre Maurikios Stratégikon címü munkájában találunk jó adatokat. A forrás szerint az avar hadsereghez jelentős számú lóállomány tartozott, mely lovak föként tartalékként, cserelovakként szolgáltak a harcosok számára, másrészt nagyobb számúnak tünhetett tőlük a hadsereg is (MAURIKIOS XI. 2, 9, 13-14. vö. SZÁDECZKY-KARDOSS 1998, 83). Maurikios egy másik passzusában ez utóbbira utal azzal, hogy felhívja a figyelmet arra: a bizánciak tapasztalt katonákat küldjenek felderítésre, ugyanis a gyakorlatlan harcost tapasztalatlansága folytán az avarok nagyszámú tartalék lova megzavarhatja, és nem tudja felmérni a „szkíta” hadsereg létszámát reálisan (MAURIKIOS IX. 5, 5. vö. SZÁDECZKYKARDOSS 1998, 82). ${ }^{314}$

Az avarok hadászatában megfigyelhető az is, hogy különböző varázslási praktikákhoz is folyamodtak a győzelem elérése érdekében. Tours-i Gergely történeti munkájában Baján kagán és I. Sigibert frank király második összecsapásakor az avarok győzelmét azzal magyarázza a szerző, hogy az avarok jártasak különféle mágikus praktikákban, és különféle kísértetalakokat jelenítettek meg, akiknek a segítségével diadalt arattak a frankok felett (GREGORIUS TURONENSIS IV. 29. vö. Adamik-Mezei 2010, 292). ${ }^{315}$ A forrás értékelésekor felmerülhet az a lehetőség, hogy a szerző a frank vereséget ily módon próbálta meg „szépíteni.” Azonban fontos hangsúlyozni, hogy a nomád népek körében nem példa nélküli ez a jelenség. ${ }^{316}$ Az avaroknál is megfigyelhető még egy másik, bár az avarokra vonatkozóan eléggé kétséges forrásértékü munkában, hogy a háborúban túlvilági erőket próbálnak a maguk oldalukra állítani. ${ }^{317}$

\footnotetext{
${ }^{313}$ A nomádokkal kapcsolatos további adatokat lásd még a hun fejezet pszichológiai hadviseléssel foglalkozó alfejezetében.

314 A T'ang-suból kiderül, hogy az ujgurok is hasonló taktikát alkalmazhattak. A támadó ujgur hadsereg létszámát 100 ezer före becsülték, azonban a felderítők híradásaiból kiderült, hogy csupán egy négyezer fös seregről van szó, amelyet 10 ezer családtag és 40 ezer ló kísért (MACKERRAS 1972, 70-71; ZIMONYI 2005, 87). A mongolokról pedig Plano Carpini írja, hogy az ütközet alkalmával a csata helyszínétöl messzebb, ahol a vezérkar áll fel, lóháton ülő gyermekekkel, asszonyokkal és olykor lóra ültetett emberalakokkal próbálták a „harcos tömeg” látszatát kelteni (Plano Carpini VI. 14. vö. GYÖRFFY 1965, 60).

315 A Tours-i Gergely történeti munkáját felhasználó Vita Vedastinumban is megtalálható ez a részlet, miszerint „démonok kísértetalakjai játszották ki a frankokat” (Vita Vedastinum 687. vö. SzÁDECZKYKARDOSS 1998, 32).

316 Egy kései szerző, Zonaras munkájából kitünik, hogy a bulgárok az 510-es években megtámadták Illyrikumot, és győzelmet arattak a bizánciak felett a különböző varázslási praktikák és „büvös ráéneklések” segítségével (ZONARAS XIV. 4, 8-9. vö. SZÁDECZKY-KARDOSS 1979-1980, 28).

${ }^{317}$ Euagrios Szent Pankratios életével foglalkozó munkájában olvashatjuk, hogy a Dyrrachium és Athén környékén élő avarok jelentősebb isteneiket is bevetették harc közben (EUAGRIOS vö. Olajos 2001, 125).
} 


\section{2. 2. 4. A tábor védelme}

Az avar hadsereg táborának a védelméről kevés adatunk van. Maurikios szerint nem létesítenek körülárkolt tábort, viszont őrszemeket állítanak ki, amivel biztosítják, hogy ne érje öket rajtaütés (MAURIKIOS XI. 2, 10-11. vö. Szádeczky-Kardoss 1998, 83). Theophylaktos munkájában található egy érdekes adat ezzel a témával kapcsolatban. 594ben, amikor Priskos támadást indított az avar fennhatóság alatt álló Singidunum ellen, az avarok szekerekkel próbálták elsáncolni a várost. ${ }^{318}$ Végül azonban mégsem várták be a bizánciak támadását, és megfutamodtak, mielőtt Priskos serege támadott volna (TheOPhYlaktos SimoKATtÉS VII. 11, 7. vö. Olajos 2012, 254). Ezenkívül az avar hadsereg szláv segédnépe esetében emlékezik meg Theophylaktos a szekérsáncról: 594ben az Al-Duna vidékén portyázó szlávok a szekérsáncuk mögül hajították a dobódárdájukat az ellenség felé (THEOPHYLAKTOS SiMOKATTÉS VII. 2, 1-5. vö. Olajos 2012, 235). A bizánci auktorok ezen két adaton kívül több esetben is megemlítik az avarok szekereit, valószínüsíthető, hogy más esetekben is alkalmazhatták táboraik védelmére ezeket a jármüveket (CORIPPUS III. 231-401; ThEODÓROS SYNKELLOS XIII. 303, 10. vö. SZÁdECZKY-KARDOSS 1998, 109, 176; THeOPHYlaKtos SimoKATtéS VII. 13, 4. vö. Olajos 2012, 256). Erre más nomád népek esetében is van példa. ${ }^{319}$

\section{2. 3. A hadsereg egységei}

$\mathrm{Az}$ írott forrásokban találunk adatot az avar hadsereg elővédjéről, könnyü- és nehézfegyverzetű lovasságáról, a gyalogságról, a testőrségről, az ostromtechnikát alkalmazókról, valamint tartalék egységeikről. Ez utóbbiaknak elsősorban két feladatuk volt. Maurikios szerint ezeket alkalmazták lesben állásra és az ellenféllel szemben vesztésre álló csapatrészek megsegítésére.

\footnotetext{
${ }^{318}$ Hasonló jelenség figyelhető meg a kazároknál 722-ben, amikor Balanğar, a kazár főváros arab ostromakor a védők háromszáz egymáshoz erősített szekérből védőgyürüt hoztak létre az erődjük körül. Ibn al-Atīr szerint ez a szekérsánc komoly problémát okozott az ostromló araboknak (POLGÁR 1998, 47).

${ }^{319}$ Lásd a hun fejezet tábor védelméről szóló részét.
} 


\section{2. 3. 1. Elővéd}

Más nomád és nem nomád néphez hasonlóan az avar hadseregben is megfigyelhető az elővéd, ${ }^{320}$ melyről három forrás emlékezik meg. Theophylaktos Simokattés az 587/588-as avar hadjárat kapcsán tudósít arról, hogy a Kastos vezette bizánci sereg Sabulente Kanalionnál ${ }^{321}$ megtámadta az avarok elővédjét, és megsemmisítő vereséget mért rájuk (TheOphylaktos SimOKATtÉs II. 11, 9-11. vö. Olajos 2012, 112). ${ }^{322}$ Szintén Theophylaktos munkájában található még egy adat az avar hadsereg elővédjére az avarok 592-es, Bizánci Birodalom elleni hadjárata kapcsán. A forrásból kitünik, hogy ezt a csapatot a kagán a hadjárat közben szervezte meg, közvetlenül a Száván történő átkelést követően, és a bizánci seregre kellett csapást mérniük. Ez az avar elővéd azonban kudarcot vallott. Ezt követően egy feltehetően az előzőhöz képest nagyobb létszámú, 8000 fős egységet küldött előre a kagán a bizánci sereg ellen. A bizánciak azonban újból győztesen kerültek ki az összecsapásból (THEOPHYLAKTOS SiMOKATTÉS VI. 4, 4-11. vö. Olajos 2012, 219-220). A Húsvéti krónikában pedig Konstantinápoly ostroma kapcsán találunk beszámolót az avar sereg elővédjéről. A forrás szerint az avar sereg 30 ezer fönyi előcsapata 626. június 29-én érkezett Konstantinápolyhoz, míg a fősereg a kagán vezetésével egy hónappal később, július 29-én tűnt fel a bizánci fővárosnál. Az elővéd feladata az volt, hogy elfoglalja a Hosszú Falat, ennek hatására a városon kívüli bizánci lovascsapatok pedig a Theodosiosi falak mögé húzódtak vissza. A nomád nép előcsapata megpróbálta megakadályozni, hogy a falakon kívülre jöjjenek, és takarmányt takarítsanak be az állatok számára. Míg a fösereg megérkezett, több kisebb összecsapás is történt a bizánci katonák és az avar előcsapat között, melynek során bizánci harcosok és polgárok is avar fogságba estek (CHRONICON PASCHALE 717, 1-22, 719, 5-16. vö. SzÁDECZKYKARDOSS 1998, 174, 184). A fent említett két forrásban nem történik utalás arra, hogy alávetett segédnépekből verbuválódott volna az avar kagán elővédje. Alkothatták ezt a csapategységet avarok is, azonban valószínübb, ahogy más nomád népeknél is megfigyelhető, hogy alávetett nomádok népekből, szlávokból, gepidákból szerveződhetett. Egy harmadik forrás egyértelmüen utal arra, hogy az avar hadsereg elővédjét szlávok alkották. Fredegar krónikájából kitünik, hogy a 623/624-ban az avaroktól függetlenedő

\footnotetext{
${ }^{320}$ A további nomád analógiákat lásd a hun fejezet elővédről szóló részében.

${ }^{321}$ Nem egyértelmü az azonosítása a területnek. Elsősorban a két folyóágból egyesült Kamčija folyóval környékével azonosítható (OLAJOS 2012, 112).

${ }^{322}$ Theophanes - Theophylaktos munkáját felhasználva - szintén megemlékezik a bizánci hadsereg által tönkrevert avar hadsereg elővédjéröl (THEOPHANES 6079. vö. SZÁDECZKY-KARDOSS 1998, 71).
} 
vendek az „összecsapáskor a küzdelemben kettős csatasort alkotva haladtak a hunok előtt” (Fredegar V. 48. vö. SZÁDECZKY-KARDOSS 1998, 173).

\title{
4. 2. 3. 2. Könnyüfegyverzetü lovasság
}

\author{
$\mathrm{Az}$ írott források adatait vizsgálva megállapítható, hogy az avar hadseregben a \\ könnyűfegyverzetủ lovasíjász ${ }^{323}$ harcmodor nem jelenik meg olyan hangsúlyosan.
}

${ }^{323}$ Az avarok lovainak a jellemzésére sem térnek ki a források. Maurikios is csak azt hangsúlyozza, hogy jelentős számú tartalék lovuk van. Viszont az avar kori lovastemetkezések jó adatokat szolgáltatnak e lovak küllemére. Ezek az állatok alacsony marmagasságúak voltak (135-140 cm) (BARTOSIEWICZ 2009, 77). A bizánci császár utal az avarok rideg lótartására: „télen-nyáron folyvást legeltetik a lovaikat”, továbbá az avar lovak vértezetére (MAurikios XI. 2, 7, 9, 10; I. 2, 6. vö. SzÁDECZKY-KARDoss 1998, 83, 80). A bizánci források közül Maurikios (I. 2, 7) müvében olvasható először a kengyel használata, melyet az eredetileg lépcsőt jelentő $\sigma \kappa \alpha \lambda \alpha$ szóval fejez ki (SzÁDECZKY-KARDOSS 1983, 323). Arra vonatkozóan, hogy a kengyelt az avaroktól vette volna át a Bizánci Birodalom, és később az ő hatásukra terjedt volna el ennek az eszköznek a használata Nyugat-Európában, megoszlik a kutatók véleménye. Szádezky-Kardoss Samu úgy véli, bár a Stratégikon kengyelt említő passzusában nem említi a hadászatban jártas szerző konkrétan, hogy a bizánciak az avaroktól vették volna át ezt az eszközt, ennek ellenére a szövegkörnyezetből erre lehet következtetni. Véleménye szerint Maurikios a bizánci hadsereg számára előírt vaskengyel használata esetében is az avar harcos felszerelésének utánzását ajánlja a császári hadvezetés figyelmébe, még ha nem is utal külön erre a körülményre. A kengyelről szóló paragrafust megelőző és követő részben egyértelmüen megnevezi az avarokat, akiknek példáját követnie kell a bizánci harcosoknak a lovak vértezete és a lovassági zubbony szabása kapcsán. Szádeczky-Kardoss hangsúlyozza, hogy Maurikios híradása egybecseng a régészeti anyag tanúságával, vagyis Európában az avarokhoz köthető régészeti anyagban tünik fel elöször a vaskengyel (SZÁDECZKY-KARDOSS 1983, 323-324). Az utóbbi időben azonban felvetődött annak a lehetősége, hogy a kengyel használatának európai elterjedése nem avar, hanem bizánci közvetítéssel történt. A fó érv erre vonatkozóan, hogy Maurikios ennél az eszköznél nem emeli ki egyértelműen, hogy az avarok mintájára kellene átvennie a használatát a bizánci hadseregnek. Míg más esetben a bizánci császár precízen megadja az egyes fegyverek, eszközök származását, addig a kengyelnél ezt nem tette meg. Freeden szerint a háromélü nyílhegyhez és nádlevél alakú döfölándzsahegyhez hasonlóan a kengyel esetében is elmondható, hogy ennek kapcsolatai a bizánci területen sokkal egyértelmübbek (például FREEDEN 1995, 622, 624). Felvetődött a lehetősége annak is, hogy Bizánc a Selyemút kereskedelmi kapcsolatain keresztül ismerkedhetett meg ezzel az eszközzel. Azonban ez a feltevés nem bizonyítható egyértelmúen (CSIKY 2013, 77). Mindenesetre Szádeczky-Kardoss filológia érvei meggyőzőbbnek tünnek az avar közvetítéssel kapcsolatban. További problémát vet fel a kengyel használatával kapcsolatos előnyök megítélése. A kengyel használatát sokáig tévesen a hátrafelé forduló nyilazó harcmodorral hozták kapcsolatba. Azonban a perzsiai ábrázolásokon egyértelműen kengyel nélkül ábrázolják a hátrafelé nyilazókat, emellett a gyakorlatban is bizonyított, hogy a hátrafelé nyilazásnak nem szükségszerű velejárója ennek az eszköznek a használata. Kürti Béla és Lőrinczy Gábor úgy vélik, hogy ezzel szemben a nehézpáncélos harcmodor esetében, ahol a páncéltörő döfőlándzsával való ütközésnél fontos volt az alapos megtámaszkodás, valóban nagy jelentőséggel bírt a kengyel használata (KÜRTI-LÖRINCZY 1992, 7). Ezzel kapcsolatban azonban hangsúlyozandó, hogy a nomádok között a szarmaták és az alánok jelentős nehézlovassággal rendelkeztek, mégsem használtak kengyelt, tehát a nehézfegyverzetü lovasságnak sem lehetett előfeltétele a kengyel (HAZANOV 1968, 183; HAZANOV 1971, 78; MielCZAREK 1993, 96). Ujabban Florin Curta vetette fel a maurikiosi idézettel kapcsolatban, hogy a kengyel segítségével vált lehetővé a harc közben az íj, a lándzsa és a kard cseréje (CURTA 2008, 313-314, 320). A kengyel ezenkívül a könnyüfegyverzetü harcmodorban, a közelharcban játszhatott még föszerepet. A viszonylag rövidre húzott szíjon lévő kengyelbe támaszkodva, a nyeregben behajlított lábbal ülő lovas a ló mozgási energiáját is hasznosította, s a törzsének és karjának összehangolt mozdulatával csuklóból irányította a szablyát (KOVÁCS 2003, 322-323). A szablya gyakorlati használatára lásd SzÖLLŐSY 2001, 279. A szablya azonban az avaroknál egyértelmüen csak a 7. század utolsó harmadától, a közép avar kortól adatolható (GARAM 1991, 142-160; CSIKY 2009, 198), vagyis a kengyel megjelenésénél későbbre datálható. A kengyel eredetével kapcsolatban lásd még IVANIŠEVIĆ-BUGARSKI 2012, 135-277. Az avar kori lószerszámzatra lásd például BóNA 1980, 31-95; KISS 1991, 431-462; KISS 1993, 197-224; SZENTPÉTERI 1993b, 49-77; GARAM 1995, 354-367; KISS 1996, 107-143; BENDE 1998, 195-230; CSUTHY 2012, 163-186. 
Maurikios hadászati munkájában is - amellett hogy a könnyüfegyverzetü lovas harcmodor sajátosságait hangsúlyozza - az íjat a lándzsával alapvetően egyenrangú fegyvernek határozza meg az avaroknál (MAURIKIOS XI. 2, 6. vö. SzÁDECZKY-KARDOSS 1998, 83). Maurikios munkáján kívül az íjat és a nyilat összesen öt forrás említi meg, melyből három a bizánci-avar háború, egy pedig a frank-avar háború időszakára vonatkozik. Ebből a Szent Demeter csodáiban és a kései szerző, Plótinos Thessalonikeus munkájában Thessalonike ostromának leírásakor található ijra és nyílra vonatkozó adat (MIRACULA S. Demetrit I (14) 139, II (2) 208; Plótinos Thessalonikeus 9-12. vö. SzÁdeCzKYKARDOSS 1998, 115, 160, 119). Geórgios Pisidés pedig egyszerűen „töltelékszóként” használja az íjat és a nyilat arra, hogy az avarok hirtelen, meglepetésszerü támadást intéztek 623-ban (GEÓRgIOS Pisidés 113-124, 197-225. vö. SZÁDECZKY-KARDOSS 1998, 166, 179). Az avar-frank háborúk időszakából Paulinus Aquileiensis Erich friauli gróf 799-ben történt megölése kapcsán említik a nyilat (PAULINUS AQUILEIENSIS 10. vö. SZÁDECZKY-KARDOSS 1998, 301). Ez természetesen nem jelenti azt, hogy az avaroknál a könnyüfegyverzetü lovasíjász harcmodor ne lett volna meghatározó. Egyrészt megjegyzendő, hogy az avarokról megemlékező források közül - kivéve Maurikiost hiányoznak azok a típusok, melyek általánosságban jellemzik a harcmodorukat. Másrészt az auktorok főként röviden emlékeznek meg az avarok sikeres támadásairól, nagyon ritkán írnak le részletesebben csatákat. Ez alól talán csak Theophylaktos Simokattés kivétel, aki a történeti munkájában háromszor is viszonylag részletesen beszámol az avarok és a bizánciak közötti összecsapásról, ${ }^{324}$ de amellett, hogy többször utal az avar sereg csapategységszámára, egyik esetben sem említi meg az avarok taktikai elemeit, fegyverzetét. ${ }^{325}$ Emellett a régészeti forrásokból is kitűnik, hogy az íjat és a nyilat az egész avar koron át általánosan használták (CS. SEBESTYÉN 1931, 178-304; CsALLÁNY 1939, 148-149; CSALLÁNY 1946-1948, 364; SzÖLLÖSY 2004). A távolharc mellett a közelharci fegyverek közül a könnyüfegyverzetü lovasságra jellemző szablya és ütő- és sújtófegyverek közül az előbbi csak a régészeti anyagban fogható meg a közép avar korszaktól kezdve (GARAM 1991, 142-160; CSIKY 2009, 198-199; CSIKY 2013, 82-83). Az ütő- és sújtófegyverekről ugyan megemlékeznek az írott források, azonban nem, mint a könnyüfegyverzetü lovasság eszközéröl (Miracula S. DEMETRII I. 14. 139, 147. vö.

\footnotetext{
${ }^{324}$ Az 587/588-ben Sabulente Kanalionnál történt ütközet (SZÁDECZKY-KARDOSS 1998, 67), az 589-es Iastros melletti csata (SZÁDECZKY-KARDOSS 1998, 126) és Priskos 599-es hadjárata (SZÁDECZKY-KARDOSS 1998, 132).

${ }^{325}$ Pohl ezt a jelenséget azzal magyarázza, hogy Theophylaktos nagyobb hangsúlyt fektetett a bizánci viszonyok ábrázolására (bizánci hadvezérek, bizánci császár tevékenységére), mint az ellenfél (avarok) jellemzésére (POHL 1988, 158).
} 
SZÁDECZKY-KARDOSS 1998, 115). A régészeti anyagban viszont tetten érhető a jelenlétük az egész avar koron át. Úgy tünik, hogy a késő avar korban gyakoribb a használatuk (SIMON 1995, 119; SzÜCSI 2012, 121-129). Tehát az írott források adataiból semmiképpen nem következtethetünk arra, hogy a könnyüfegyverzetü lovasság ne lett volna meghatározó az avarok harcmodorában. Erre utal végeredményben az is, hogy Maurikios ennél a nomád népnél részletesen kielemezte a könnyűfegyverzetủ lovasságuk taktikai elemeit.

Maurikios császár az avar hadsereg esetében hangsúlyozza, hogy jellemző rájuk a távolharc, lesben állás, bekerítés, színlelt megfutamodás és az ék alakú (szétszóródó) alakzat (MAURIKIOS XI. 2, 15. vö. SzÁDECZKY-KARDOSS 1998, 83). Az avar korszakot megelőző időszakokban ${ }^{326}$ már többször feltűnő színlelt megfutamodás taktikáját az avarok esetében szintén Maurikios írja le részletesen. A korábbi források nem tértek ki ennyire részletesen erre a taktikára. A hadászatban jártas tudós császár szerint „,az összecsapás megtörténtével azok, akiket elöre állitottak, szándékosan megfutamodnak, és ha az ellenség hadrend nélkül végzi az üldözést, miután azok túlhaladtak a leshelyen, a lesben állók elötörnek, és hátba kapják az ellenséget. Azután a megbeszélt jelre a megfutamodók is visszafordulnak és közrefogják öket” (MAURIKIOS IV. 2. ford. SZÁDECZKY-KARDOSS 1998, 81). Mint már utaltam rá a hun fejezetben, a hiung-nuktól kezdve az alánokon és a hunokon át megfigyelhető ez a taktika, amit más letelepült népek is átvettek és alkalmaztak. Ugyanakkor ennek a taktikai elemnek a lesben állás, bekerítés eleme az avaroknál tűnik fel először. ${ }^{327}$ A bekerítés, mint taktikai elem természetesen nem csak kizárólag a színlelt megfutamodáshoz kapcsolódik. ${ }^{328}$ Az avaroknál is megfigyelhető más kontextusban. Erre jó példa, hogy az avarok egy egysége 623-ban a kagán parancsára Konstantinápolynál, a Hosszú Falak feletti bozótos terepen rejtőzött el, hogy meglepetésszerüen rajtaüssenek Herakleios császáron (610-641) és kísérőin (NIKEPHOROS PATRIARCHA 12, 29-14, 10. vö. SZÁDECZKY-KARDOSS 1998, 165). ${ }^{329}$ Az avaroknál is megtalálható ék alakú alakzatra már részletesen kitértem a hunok harcmodorával foglalkozó fejezetben, amelyből kiderül, hogy szétszóródó, több egységből álló, laza

\footnotetext{
326 A színlelt megfutamodás taktikájára vonatkozó nomád párhuzamokat lásd a hun fejezet könnyüfegyverzetü lovassággal foglalkozó részében.

${ }^{327}$ A későbbiek folyamán megfigyelhető például a mongolok taktikai repertoárjában is (Plano Carpini VI. 13. vö. GYÖRFFY 1965, 81).

${ }^{328}$ Plano Carpini munkájában a mongoloknál figyelhető meg nyílt ütközet során ez a jelenség, amikor is kiváló harcosokból álló csapatok több irányból - az ellenfél látótávolságán kívül - bekerítő hadmozdulatokat hajtottak végre (Plano Carpini VI. 14. vö. GYÖRFFY 1965, 81-82).

${ }^{329}$ Herakleios császárnak ugyan sikerült elmenekülnie, azonban az avarok jelentős számú foglyot ejtettek ebben a hadivállalkozásukban (NIKEPHOROS PATRIARCHA 12, 29-14, 10. vö. SZÁdECZKY-KARDOSS 1998, $165)$.
} 
csatarendröl van szó. Megállapítható továbbá, hogy az avaroknál is nemzetségi, törzsi alapon szerveződő hadrendi egységekről lehetett szó az ékek esetében (NIKONOROV 2002, 241-242; NiKONOROV 2010a, 273-274). Bár az írott forrásokban nem érhető tetten az avarok kapcsán a hátrafelé nyilazás jelensége, ami más nomád népeknél hangsúlyosan jelenik meg a színlelt megfutamodás taktikájában, azonban egy az avarokkal azonosítható ábrázoláson szerepel ez a nyilazási mód a frank-avar háborúk időszakából (MESTREHÁzY 1968, 245-247; BÓNA 1984, 79. kép; BACHRACH 1984, 5-24). ${ }^{330}$

A frank-avar háborúk időszakában az avarok harcmodora szempontjából ellentmondó vélemények figyelhetők meg Nagy Károly 791-es hadjáratának elemzésekor. Nagy Károly serege három részre osztva vonult a Duna mentén kelet felé, és a frank források szerint a folyó déli részén a Bécsi erdőnél Cumeobergnél, az északi részen pedig Campnál lévő erődítményeknél lévő avarok rémülten elmenekültek, majd a frankok a Rába-torkolat vidékéig nyomultak előre. Majd ezt követően visszafordultak, és hazatértek (Annales regni Francorum 791.vö. SzÁDECZKY-KARDOSS 1998, 279). A cumeobergi kisebb összecsapástól ${ }^{331}$ eltekintve a források szerint nem ütközött meg egymással a frank és az avar sereg. A kutatók egy része úgy véli, hogy a források hitelt érdemlően mutatják be a hadjáratot, mely szerint összecsapásoktól mentes, eseménytelen volt, és az avarok nem mutattak ellenállást (POHL 1988, 315-317; WOLFRAM 1987, 256-257; SzŐKE 2006, 505-509). Váczy Péter ezzel szemben úgy véli, hogy az avarok a frankok ellenében a „meghátrálás taktikáját” alkalmazták. Véleménye szerint a 791-ben, 795-ben és 796-ban bekövetkezett frank, ,győzelmek” tudatos avar taktika következményei, amivel a „frankokat olyan győzelemhez juttatták, amelyet azok nem tudtak gyümölcsöztetni” (VÁCZY 1974, 1057). ${ }^{332}$ Hasonló az álláspontja Bóna Istvánnak is, aki szerint az avarok a felperzselt föld taktikáját alkalmazták, és a frank hadsereg útvonalában kutakat, vizeket mérgeztek meg, élelmiszert és takarmányt pusztítottak el, hogy ezzel visszavonulásra

\footnotetext{
${ }^{330} \mathrm{Az}$ eurázsiai-steppén is ritka jelenségnek tekinthető a hátrafelé íjazás ábrázolása, csak néhány esetben figyelhető meg. Például a közép-ázsiai Varashában vagy egy Mongolia területéröl származó kerámiatöredéken [3., 4., 5. kép] (MOGILNYIKOV 1981, 126; TABALDIEV-BABAJAROV-UMIROV-JACENKO 2013, 555; KUBAREV-KUBAREV-BAJÁR 2013, 648).

${ }^{331}$ Walter Pohl úgy véli, hogy a forrásokból nyerhető információk hitelt érdemlőek, és az avarok nem fejtettek ki ellenállást a frankok ellenében (PoHL 1988, 315-317). Váczy Péter szerint sem volt jelentős összecsapás Cumeobergnél, ugyanis véleménye szerint az avarok felperzselt föld taktikáját alkalmazva elhagyták ezeket a helyörségeket (VÁCZY 1974, 1049). Bóna István ezzel szemben úgy véli, hogy a Bécsi erdőnél jelentős összecsapás zajlott az avarok és a frankok között, melyben a frankok győzelmük ellenére jelentős veszteségeket könyvelhettek el (BóNA 1994, 70-72).

332 Váczy szerint a 796 és 803 közötti időszak háborús eseményei cáfolják azt a nézetet, hogy az avarok „elpuhultságából”, politikai széttagoltságuk miatt tudtak a frankok 791-ben, majd 795-ben és 796-ban győzni ellenük. Emellett hangsúlyozza azt is a szerző, hogy a frankok nem tudtak jelentős területeket sem megszerezni még ebben az időszakban az avaroktól (VÁCZY 1974, 1057).
} 
kényszerítsék Nagy Károly seregét. A kialakult helyzetet még súlyosbították a tömegesen elhulló lovak és az őszi esőzések, melyek hatására jelentősen megduzzadt a Duna, ami nehezítette a kapcsolattartást a seregrészek között. Bóna hangsúlyozza, hogy Nagy Károly hatalmas kudarcának tekinthető ez a hadjárat, melynek hatására többé nem vezetett hadat. Ennek az eseménynek tudja be Bóna a szászok lázadását is (BóNA 1984, 339-340). A Bóna István és Váczy Péter által feltételezett a taktika bár nem tekinthető nomád specifikumnak, nem ismeretlen a nomád népek körében sem. ${ }^{333}$

\section{2. 3. 3. Nehézfegyverzetü lovasság}

Az avar hadsereg nehézfegyverzetű lovasságára több forrás utal a bizánci-avar háborúk időszakából. Pusztán a vértezet említése mellett néhány esetben megfigyelhető a páncélozott lovasság hangsúlyozása is. Erre vonatkozóan találunk adatot a Maurikiosnál, Menandros Protéktórál és a Szent Demeter csodáiban egy, valamint Theodóros Synkellos munkájában két helyen. Mind a három forráshelyen páncélozott, vasba öltözött lovasságról van szó (Menandros ProtéKTór 208, 11-210, 2; Miracula S. DemetriI II.2 199; Maurikios XI. 2, 6; TheOdóros Synkellos XVIII 305, 13-36; XXIV 308, 1-21; XLVI 317, 29-36, 318, 2-5). ${ }^{334}$ Maurikios és Theodóros Synkellos egyértelmüen utal a lovak vértezetére is (MAURIKIOS I. 2, 6; XI. 2, 7). Menandros Protéktór, Theodóros Synkellos munkáiban és a Szent Demeter csodáiban egyértelmüen megfigyelhetö, hogy a szerzők hangsúlyozzák, ezek a páncélosok nagy létszámúak voltak. ${ }^{335}$ Annak ellenére, hogy miként a hunoknál már megfogalmaztam, kérdéses, mennyire utalhat pusztán egy harcos páncélozottsága nehézfegyverzetü lovasságra, ezekből az adatokból arra következtethetünk, hogy fontos szerepe lehetett a bizánci-avar háborúk időszakában a nehézfegyverzetű lovasságnak. A támadó fegyverzetek közül a nehézlovasságra jellemző hosszú kétélü kardok egyértelmüen tetten érhetők az írott forrásokban, a döfőlándzsa jelenléte azonban nem egyértelmü a kútfők adataiból. ${ }^{336}$ Mint ahogy a fegyverzet

\footnotetext{
333 Például a szkíták is ezt alkalmazták sikeresen a Kr. e. 510-es években a délorosz steppét megtámadó perzsák ellenében (HÉRODOTOS IV. 122-123. vö. Muraközi 2000, 308).

334 A régészeti anyag is egyértelmüen alátámasztja ezt: lásd az avar fegyverzet páncélzattal foglalkozó alfejezetét.

${ }^{335}$ Menandros Protéktór 60 ezer páncélos lovasról számol be Baján 578-as, al-dunai szlávok ellen indított hadjárata kapcsán (MENANDROs ProtéKTóR 208, 11-210, 2. vö. SzÁdECZKY-KARdoss 1998, 46). A létszámadatattal kapcsolatos értékelést lásd az avar hadsereg létszámával foglalkozó fejezetben.

${ }^{336}$ A régészeti anyagban mindkét fegyvertípus: hosszú kétélü kard (SIMON 1991, 269-270, 281; CSIKY 2009, 196-197; CSIKY 2013, 81) és döfölándzsa is megfigyelhető a kora avar korszakban. A lándzsák közül
} 
fejezetben említettem, a nehézfegyverzetű lovasság által használt hosszú döfőlándzsára következtethetünk esetleg a hadászati munka szerzőjének három megjegyzéséből: a lándzsa nyele zászlóval, középen szíjjal van ellátva, és az íjjal felváltva használták az avarok. Maurikios utal az avarok lándzsahasználatára is. A hadászatban jártas bizánci császár szerint az avarok az íjat és a lándzsát felváltva használták: ez arra utalhat, hogy első lépésként az ijat vetették be, amivel felbontották az ellenfél egységes arcvonalát, majd ezután támadhattak a hosszú döfölándzsával. ${ }^{337}$ A frank-avar háborúk időszakában azonban az avarok nehézfegyverzetű lovasságáról csak néhány, gyér adat áll a rendelkezésünkre, melyekből nem lehet messzemenő következtetéseket levonni. Erre az időszakra főként képi ábrázolásokból következtethetünk, legjobb példa erre vonatkozóan a nagyszentmiklósi kincs 2. számú korsóján látható „győztes fejedelem”, akit gyürüs páncéllal, sisakkal, lábvérttel és zászlós lándzsával ábrázoltak (BÁLINT 2004, 416-420, 424). ${ }^{338}$ Továbbá fontos megemlíteni Nagy Károly 805. évi dietenhofeni rendeletét, mely utalhat arra, hogy a frank-avar háborúk időszakában frank típusú páncélt és más fegyvereket is használhattak, például lándzsát, amelynek alkalmazását régészeti lelet is alátámasztja.

A Stratégikonban az avarok lándzsájához tartozó szíj szerepe, jelentősége nehezen

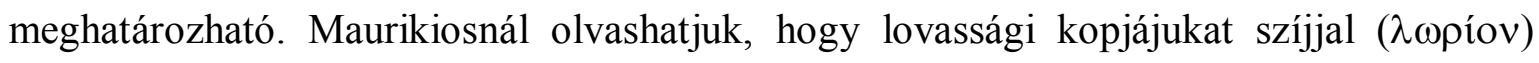
látják el középen. Már az sem egyértelmü a szövegből, hogy harc közbeni vagy szállításkori felerősítésről van-e szó. Ha ez előbbi lehetőség áll fenn, akkor jó párhuzamát találjuk Héliodoros müvében, aki leírja egy szaszanida harcosról, hogy lándzsanyele a ló nyakához és farához volt erősítve. ${ }^{339}$ Itt a harcos ereje alig játszott szerepet a lökés lendületében, csak a ló mozgásának a sebessége és az, hogy a rögzített lándzsa nem engedett (KoliAs 1988, 203). ${ }^{340}$ Ehhez a lándzsatartási módhoz azonban két szíjra volt szükség. Az avarok esetében viszont nem figyelhető meg egyértelmüen a forrásban az,

elsősorban a keskeny nádlevél alakú lándzsacsúcsok (BÓNA 1980, 47-48; CsIKY 2013, 76), valamint a kónikus hegyűek (CSIKY 2013, 76) a nehézfegyverzetű lovasság döfölándzsáival.

${ }^{337}$ Hasonló figyelhető meg az alánok harcmodorában is: az ellenség arcvonalát nyílzáporral bontották meg, amit pedig a lándzsás harcosok támadása követett (SZLANOV 2000).

${ }^{338}$ A késő avar korra datálható képi ábrázolások részletes elemzését lásd HuSÁr 2007, 29-41; FANCSALSZKY $2007,108-114$.

${ }^{339}$ Héliodoros a nehézfegyverzetủ lovasság egy speciális típusa, a cataphractariusok nehéz döfölándzsáinak a használatát írja le, miszerint a harcos kopja hegye erősen elörenyúlik, maga a kopja szíjjal van a ló nyakához kötve; a lándzsanyél vége pedig a ló farához van erősítve. Az összecsapásoknál a harcos kezének a segítsége nélkül nem használható, de irányítással az megfeszül, és keményen nekitámaszkodik. Súlyos sérülést okoz, és a lendületes elöretörés nem egy embert szúr át, hanem kettőt (Héliodoros IX, 5. vö. HAZANOV 1968, 182).

${ }^{340}$ Míg ezt a lándzsatartási módot Hazanov, Kolias és Szlanov elfogadja (HAZANOv 1968, 182; KoliAs 1988, 203; SzLANOv 2000), addig Mielczarek szerint ez inkább a fantázia szüleménye (MieLCZAREK 1993, 46). 
hogy két szíjat alkalmaztak volna. Maurikios viszont művének egy másik részében ezt írja az avarokról: „A harcokban legtöbbjük kétféle fegyvert visel, vállukon kopját hordanak, kezükben ijat tartanak, és ahogy a szükség megkívánja hol az egyiket, hol a másikat használják” (MAURIKIOS XI. 2, 6. ford. SZÁDECZKY-KARDOSS 1998, 83). A Maurikiosnál olvasható két említett adat (I. 2, 2; XI. 2, 6) együttesen is értelmezhető. Vagyis a lovasoknak gyorsan kellett váltani az íjat és a lándzsát, és amikor a harcos az íjat használta, addig szíjjal felerősítve a hátán/vállán vagy a lovára erősítve lóghatott a lándzsa, amit használatakor onnan vehetett elő. Ezenkívül a szövegkörnyezetből kevésbé feltételezhető az a lehetőség is, hogy Maurikios mindkét fegyver harc közbeni (külön-külön történő) használatát örökítette meg. Eszerint a lándzsát jobb kézzel a ,vállukon”/válluk fölött használták. Ez a lándzsatartási mód azonban felveti annak a lehetőségét is, hogy esetleg dobólándzsáként alkalmazták ezeket a fegyvereket (KOLIAS 1988, 203). De a nehézfegyverzetü lovasság is használhatta így a hosszú döfőlándzsát. Erre találunk példát a belső-ázsiai türk kori ábrázolásokon, ahol két kézzel a válla fölött tartja a zászlós lándzsáját a lovas [12. kép] (MOGILNYIKOV 1981, 126). ${ }^{341}$ Ez esetben felülről lefelé történő döfés rekonstruálható, mint az az afrasziai vadászatot megörökítő ábrázolásokon is látható [14., 15. kép] (Albaum 1975, 61, 67). ${ }^{342}$ Egy negyedik lándzsatartási mód is érvényesült az eurázsiai steppén (és azon kívül is), amely széles körben elterjedt volt ebben az időszakban. Ebben az esetben a lándzsanyelet beszorították a hónaljukba vagy a combjukhoz leszorították, és mindkét kezükkel fogták. A lándzsát vagy a ló nyakával párhuzamosan tartották, vagy a nyaka előtt keresztbe tették [11., 13., 16., 17., 18., 19. kép]. ${ }^{343}$ A lovas ereje így a fegyver tartásánál és a pontos célzásnál játszott szerepet. A döfési erő a ló gyorsaságán és az ebből eredő ütközési lendületen múlott. Az ilyen technikával tartott lándzsa annyira stabilan állt, hogy gyakran eltörött a nyél az ütközésnél a túlontúl sürű páncélzat miatt (Kolias 1988, 204; MielCZAREK 1993, 44-45). Ezen a tartási módot elősegíthette a fegyver "lándzsanyél-papucsa" (nyél végén található fémtokot). Ez ellensúlyozhatta a hegyet, és a fegyver súlypontja hátrébb került, ami által értékes hosszelőnyt nyertek a nyél esetében (KoliAs 1988, 199). A bizánci szerzők az

\footnotetext{
${ }^{341}$ A késő avar korra datálható Balatonszőlős-TSZ-istálló temető A. sírból előkerült korong alakú bronzvereten látható egy lándzsás harcos, aki jobb kezében tartja ezt a fegyvert. Az ábrázolt mozdulatból azonban nem lehet egyértelmüen eldönteni, hogy dobni akarja-e vagy felülröl lefelé akar szúrni [8. kép] (NÉMETH 1969, 154-156; FANCSALSZKY 2007, 113; CSIKY 2009, 239).

${ }^{342}$ Ez esetben felmerül annak a lehetősége, hogy a balatonszőlősi vereten sem dobódárdatartás látható, hanem a döfólándzsa, amellyel felülröl lefelé szúrhat a lovas, amint erre már Csiky Gergely is utalt [8. kép] (CSIKY 2009, 239).

${ }^{343}$ A közép-ázsiai pendzsikenti ábrázolásokon a ló nyakával párhuzamosan tartják a lándzsát a lovasok (BELENIZKI 1980, 116).
} 
avarok kapcsán nem említenek ilyen tárgyat, viszont a késő avar kori régészeti anyagban ${ }^{344}$ ismert néhány ilyen darab. Ezeknek a fegyvertartási módnak elöfeltétele volt a biztos nyeregben ülés, amit a magasított nyeregkápa tett lehetővé, és még feltehetőleg a steppén akkor már széles körben elterjedt kengyel használata is elősegített.

Az avar nehézfegyverzetü lovassággal foglalkozók közül Joachim Werner nevét érdemes elsőként kiemelni, aki a 6. századra datálható itáliai, Isola Rizzai kincslelet ezüsttálján látható nehézfegyverzetü lovas ábrázolásának értékelése kapcsán utal az avarok nehézfegyverzetű lovasságára [16. kép]. Az ábrázolás értékelése kapcsán felhasználta Maurikios Stratégikon címü munkáját, és a bizánci nehézfegyverzetű lovas esetében hangsúlyozza, hogy a páncél alatti alsóruházat és a lándzsa avar származású. A tálon látható harcos védő- és támadófegyverei közül a lemezes páncél, a pántos sisak és a hosszú döfőlándzsa figyelhető meg. Ez utóbbival a tálon látható jelenet alapján éppen egy gyalogos harcost döf át a páncélos lovas. A harcos lándzsáját két kézzel fogja, és a combjához szorítva, stabilizálva használja (WERNER 1974, 111, I. tábla 1. kép). Elsőként azonban Bóna István próbált átfogó képet rajzolni az avar nehézfegyverzetű lovasságról. Hangsúlyozta, hogy az avar hadsereget nem lehet pusztán csak könnyüfegyverzetü lovasíjászoknak tekinteni, véleménye szerint Maurikios Stratégikonja és a régészeti leletek tanúsága szerint az avar hadsereg magvát közép-ázsiai perzsa típusú nehézfegyverzetü lovasság alkotta. Ezen csapategység fegyverzete közül a lamellás vértezet mellet a lándzsa szerepét is kiemelte. Bóna szerint az avar régészeti anyagban megfigyelhető nádlevél alakú lándzsa sorolható a nehézfegyverzetü lovasság jellegzetes támadófegyverzetéhez, mely keleti eredetü, és már a szkítáktól, szarmatáktól kezdve fontos szerepet töltött be a nomád népek nehézfegyverzetü lovasságában (BÓNA 1984, 321; BÓNA 1980, 47-48). Csiky Gergely az avar kori lándzsatípusokat vizsgálva arra a következtetésre jutott, hogy a nádlevél alakú lándzsák mellett a kónikus lándzsahegyek is a nehézfegyverzetű lovasság jellegzetes fegyverei közé sorolhatók. Csiky úgy véli, hogy mindkét típus esetében a kiszélesedő köpü, a vastag nyak és a penge rombusz alakú metszete alapján sorolhatók a hosszú döfőlándzsák hegyei közé (CSIKY 2013, 79). Martin Husár elsősorban képi ábrázolások részletes elemzésével vizsgálta az avarok harcmodorát. A szerző úgy véli, hogy míg az Avar Kaganátus korai időszakában (568-650) az avar hadsereg központi elitjét a közép-ázsiai perzsa típusú páncélos lovasság alkotta, addig a késői időszakban (700-800/825) jelen van mindkét lovasság, köztük a lándzsával felszerelt

\footnotetext{
${ }^{344}$ Csiky Gergely úgy véli a lándzsanyél-papucsokhoz tartozó lándzsahegyek alakjából, hogy ezek inkább dobófegyverek lehettek (CSIKY 2009, 100).
} 
könnyüfegyverzetü lovasság. Hangsúlyozza továbbá, hogy ebben az időszakban több fegyvertípus (köztük a lándzsa) a Frank Birodalom területéről származik (HUSÁR 2007, 29-41).

$\mathrm{Az}$ írott források adataiból tehát egyértelműen tetten érhető az avarok nehézfegyverzetü lovassága, ezen páncélozott egység taktikai elemei azonban már nehezebben rekonstruálhatók. Az viszont megállapítható, hogy a korai avar időszak első felében - vagyis a Bizánc elleni támadások korszakában - nagyobb jelentősége lehetett a nehézfegyverzetü lovasságnak. ${ }^{345}$ Ezen csapategységnek a védőfegyverzete főként lamellás páncél volt, de megfigyelhető a gyürüsvértezet is. Ez utóbbit a gyér számú régészeti adatokon kívül Maurikios hadászati mủve is alátámasztja. Jellegzetes támadó fegyverek közül elsősorban a hosszú döfőlándzsa hangsúlyozandó, de hosszú, kétélü kardok is ide sorolhatók. A kora avar korszak után sem szünhetett meg azonban teljesen a nehézfegyverzetü lovasság, csak az avar hadseregen belüli szerepe csökkenhetett. A késő avar kor legvégén a forrásokban (főként a képi ábrázolásokban) ismét több adatot találunk a nehézfegyverzetü lovasságra (bár korántsem annyit, mint a kora avar kor esetében). Az új ellenfél nehézfegyverzetü lovasságának egy-egy fegyvertípusát is átvehette az avar hadsereg (frank típusú „szárnyas” lándzsa, frank típusú páncél). Az viszont kérdéses, hogy az ilyen fegyvertípusokkal harcolóknak mekkora jelentőségük volt az avar hadseregben (BÓNA 1984, 321; NAGY 2005, 135-148).

\section{2. 3. 4. Gyalogság}

Az avar hadseregen belüli gyalogság jelenlétére az írott forrásokból kevésbé következtethetünk. Maurikios egyértelmủen cáfolja, hogy az avarságnak lenne gyalogsága. Ezzel kapcsolatban a bizánci császárnál is megtalálható az a toposz, ami a legtöbb nomád nép esetében megfigyelhető az írott forrásokban, ${ }^{346}$ hogy gyalogosan nem tudják felvenni a harcot, mivel lovon nőttek fel, és így járni sem képesek (MAURIKIOS XI. 2, 19. vö. SZÁDECZKY-KARDOSS 1998, 83). Ahogy más nomád népek esetében tetten érhető a gyalogságuk (türkök és szabirok), ${ }^{347}$ úgy az avarok esetében sem zárható ki ez a

\footnotetext{
${ }^{345}$ Ezzel kapcsolatban legújabban B. Szabó János tett kritikai észrevételt, aki kiemelte az avar kori régészeti anyagban a védőfegyverzet elenyésző számát (B. SzABÓ 2010, 43-44).

${ }^{346} \mathrm{Az}$ erre vonatkozó példákat lásd a hun fejezet gyalogságával foglalkozó részében.

${ }^{347}$ Lásd bővebben a hun fejezet gyalogságával foglalkozó részében.
} 
jelenség. ${ }^{348}$ Erre vonatkozóan azonban csak egy nagyon bizonytalan adat áll a rendelkezésünkre. Menandros Protéktór az avarok 578/580-as, Sirmium ellen vonulásakor említi meg az „avar gyalogságot” (MENANDROS PROTÉKTóR 471, 25-476, 25 . vö. SZÁDECZKY-KARDOSS 1998, 47). A forrásból nem lehet egyértelműen eldönteni, hogy ténylegesen avar gyalogságról van-e szó, vagy pedig az avar hadsereg alávetett segédnépeiből szervezett gyalogos kontingensröl. Míg az előbbit nem támasztja alá más forrás, addig az utóbbira vonatkozóan több forrás adata is rendelkezésünkre áll. Főként a szlávokból és a gepidákból verbuválódhatott az avar hadsereg gyalogsága, voltak közöttük nehéz- és könnyüfegyverzetü gyalogosok is. ${ }^{349}$

Lindner - hasonlóan a hunokhoz - az avarok esetében is feltételezte, hogy a hadseregük felhagyott a lovas harcmodorral, és gyalogsággá alakult át. Véleménye szerint az avarok nagy csatáikban gyalogosokként küzdöttek. Ezt az elméletét forrásokkal is alátámasztotta: úgy vélte, hogy a bizánci források alapján az 580-as, 593-as, 596-as és az 599-es összecsapásokban az avarok gyalogos harcmodort alkalmaztak (LINDNER 1981, 17). Megvizsgálva az általa említett évszámokhoz köthető eseményeket, megállapítható, hogy az 580-as évet kivéve vagy egyáltalán nem található utalás az avarság gyalogságára, vagy a forrásból egyértelmüen kitűnik, hogy az avar hadsereg segédnépéről van szó (például a szlávokról). ${ }^{350}$

\section{2. 3. 5. Testörség}

A más nomád birodalmak uralkodói esetében általában testőrségre ${ }^{351}$ az avarok esetében csak néhány bizonytalan adatból következtethetünk. Sirmium ostroma során Menandros Protéktór megemlékezik arról, hogy bőrpajzsokat tartottak az avar kagán arca és mellkasa elé, hogy így védjék meg a rómaiak fegyvereivel szemben (MENANDROS PROTÉKTÓR 476, 26-477, 18. vö. SZÁDECZKY-KARDOSS 1998, 50). Az avarok 623-as meglepetésszerü támadása kapcsán a Húsvéti krónikából kiderül, hogy az avar kagán jelt adott a támadásra, és a sereg benyomult a Hosszú Falon át. A Hosszú Falon kívül csak a kagán maradt néhány emberével (Chronicon PASCHALe 712, 9-713, 14. vö. SzÁdeCZKY-Kardoss 1998, 164).

\footnotetext{
${ }^{348}$ Bachrach úgy véli, hogy ez Ammianus Marcellinus hunokra vonatkozó jellemzésének a továbbélése Maurikiosnál. Véleménye szerint az avarok képesek voltak gyalogosan is harcolni (BACHRACH 1984, 15).

${ }^{349}$ Lásd bővebben az avar hadsereg segédnépeivel foglalkozó fejezetben.

${ }^{350}$ Nikonorov tételes cáfolatát Lindner véleményével szemben lásd a hun fejezet gyalogsággal foglalkozó részében.

${ }^{351}$ Lásd bővebben a hun fejezet testőrséggel foglalkozó alfejezetét.
} 
Bár a források nem nevezik meg, hogy milyen szerepet töltöttek be az avar hadseregen belül, ennek ellenére esetleg feltételezhető, hogy ők alkothatták az avar kagán testőrségét.

\section{2. 3. 6. „Müszaki” alakulatok (ostromtechnika)}

Az avarok történetével, hadszervezetével foglalkozó munkák többsége vagy nem említi, vagy csak felsorolásszerüen írja le az avarok ostromgépeit, de nem jellemzi azokat (POHL 1988，173; SzÁdECZKY-KARdOSS 1994，211; SZÁDECZKY-KARDOSS 1996，21; GOLDEN 2002, 152). Kivételnek tekinthetők Friedrich Lammert, Speros Vryonis, Michael Whitby és Stephen McCotter munkái. Lammert az ókori ostromtechnikák továbbéléséről szóló cikkében megemlítette az avarok kapcsán Sirmium ostromát, Busas történetét, valamint Konstantinápoly ostromát (LAMMERT 1938, 408-409). Vrynois az avar hadsereg hajítógépeit vizsgálta Thessalonike első ostromának datálása kapcsán (VRYONIS 1981, 378-390). Whitby az avarok Miracula S. Demetrii-ben található hajítógép-leírását és Busas történetét elemezte (WhiтBY 1988, 118-119, 173). McCotter pedig az avar és bizánci kőhajítógépek típusaival foglalkozott behatóbban (MCCOTTER).

Az avar hadsereg ostromgépeinek bevetése kizárólag a Bizánci Birodalom városai elleni támadások esetében szerepel a forrásokban. Ez alól csak Corippus munkája kivétel, amelyben a Bizáncban járó avar követek elmondják, hogy az avar kagán áttört az Eufráteszen, és több „erődített helyet” vett be (CORIPPUS 298-302, vö. SzÁDECZKYKARDOSS 1998, 16). E szerző költeménye kortárs munka, amely jó forrásértékkel bír a 6. századi bizánci szertartásokra vonatkozólag (BOURAS 1991, 533). Az avar követek az Eufráteszen túli erődített városok bevételéről szóló történetének forrásértéke azonban kérdéses, más forrás nem erősíti meg ezeket az eseményeket. A források (Menandros Protéktór, Theophylaktos Simokattés) tanúsága szerint az avarok által ostromlott első város Sirmium volt, melyet 581-582 táján sikerült is elfoglalniuk két évig tartó ostrom eredményeként (SZÁDECZKY-KARDOSS 1986, 71; SZÁDECZKY-KARDOSS 1998, 47-54). 584 őszén bevették Singidunumot, Augustae-t (Bulgária) és Viminaciumot, és egészen Anchialosig (ma Pomorje, Bulgária) nyomultak elöre. 586-ban (vagy 587-ben) a Bizánci Birodalomra törö avar hadsereg ,sok várost is elfoglalt”, így Ratiariát (ma Arcsar, Bulgária), Bononiát (ma Vidin, Bulgária), Aquae-t (Bulgária), Durostorumot (ma Szilisztra, Bulgária), Zaldapát (ma Abrit, Bulgária), Panassát (Bulgária), Marcianopolist (ma Devnja, Bulgária) és Tropaeumot (Adamclisi, Románia). 587-ben (vagy 588-ban) sikertelenül ostromolták Appiareiát (Bulgária), Diocletianopolist (ma Hiszarja vagy 
Csirpan, Bulgária), Philippopolist (ma Plovdiv, Bulgária), Adrianopolist. Herakleia városát 590-591 táján érte avar támadás, majd 592-ben Driziperát és Truzullont próbálták bevenni. Thessalonike városát kétszer is ostromolták eredménytelenül: 597-ben (vagy 586-ban) és 618-ban. 598-599 táján viszont Driziperát sikerült feldúlniuk az avaroknak. 603-ban az avar kagán Agilulf langobard király megsegítésére küldött szlávokat, akiknek támogatásával bevette Cremona és Mantua (Olaszország) városát. Csellel foglalták el a friauli tartomány erődjét (Cividale) 610 körül. 614 körül Salonát (ma Solin, Horvátország), majd pedig 614-615 táján Naissust és Serdicát (ma Szófia, Bulgária) vették be ostrommal. Az avar hadsereg legnagyobb - és az utolsó - hadi vállalkozása Konstantinápoly tíznapos, sikertelen ostroma volt 626-ban (SZÁDECZKY-KARDOSS 1986, 72-74, 81, 85-88, 91-92; SZÁDECZKY-KARDOSS 1998, 59-62, 65, 70, 94-95, 126, 146, 148-149, 152-153, 156, 159, 184-207).

$\mathrm{Az}$ avar hadsereg által megtámadott városok ellen az ostromgépek használatán kívül más taktika is megjelenik a forrásokban. Az egyik ilyen módszer a város körülzárása és a városlakók kiéheztetése, ami az avarok hadmüvészete kapcsán Maurikios Stratégikon címü munkájában is szerepel: „Ha pedig valamely üldözött ellenségük megerösitett helyre menekül, azon vannak, hogy pontosan kipuhatolván, hogy akár a lovak, akár az emberek miben szenvednek hiányt, mindent elkövessenek, hogy az ezekben való megszoritás útján ellenfeleiket kézre keritsék, vagy ezeket a nekik megfelelö egyezségre rábírják..." (MAurikios XI. 2, 17. ford. SZÁDECZKY-KARDOSS 1998, 83). Erre nagyon jó példát találunk Sirmium ostroma kapcsán Menandros Protéktór leírásában: az avar kagán hidat építtetett a Száván, teljesen körülzáratta a várost, és így megakadályozta az „élelem és más támogatás" oda történő eljuttatását (MENANDROS PROTÉKTÓR 471, 25-476, 25 . vö. SZÁDECZKY-KARDOSS 1998, 47-48). Ezen ostromtechnika egyik hátránya, hogy túlságosan sok időt vett igénybe, Sirmiumot például két-három év alatt sikerült bevenniük. ${ }^{352}$ Másrészről kockázatos is volt abban az esetben, ha felmentő csapatot küldtek a város megsegítésére. A másik városostrom-technika a hirtelen lerohanás, a városlakók meglepetésszerü támadása. Singidunum elfoglalásának esetében Theophylaktos Simokattés leírja, hogy a városbeliek „éppen a szabadban, a földeken tartózkodtak”, amikor az avarok hirtelen rájuk törtek (THEOPHYLAKTOS SIMOKATTÉS I. 3, 13-4, 8. vö. SzÁdECZKY-

\footnotetext{
${ }^{352}$ Sirmium sikeres ostroma esetében a kiéheztetés mellett szerepet játszott az is, hogy az avarok azt színlelték: a szlávokra támadnak a Száván túl, és nem Sirmiumot akarják bevenni. Másrészről a bizánci császárnak nem állt rendelkezésére szabad mozgósítható egysége, mivel a perzsák elleni harc elvonta a haderejének nagy részét (MENANDros ProtéKTóR 471, 25-476, 25. vö. SzÁDECZKY-KARDOss 1998, $47-$ 48).
} 
KARDOSS, 1998, 59-60). Az auktor emellett más városok ostroma esetében is kiemeli az avarok ostromtaktikájában a gyors, hirtelen lerohanás szerepét. ${ }^{353}$ Néhány forrás megemlíti, hogy az avarok csellel próbáltak bevenni erődített településeket. A friauli erődítmény (Cividale) esetében Paulus Diaconus leírja, hogy az avar kagán Gisulf friauli herceg feleségének ígéretet tett arra, hogy „,asszonyául” veszi, erre ő az ígéret hatására beengedte az avarokat a friauli erődbe (PAULus DiACONUS IV. 37-38. vö. SzÁDECZKYKARDOSS 1998, 148-149). ${ }^{354}$ Sirmium már említett ostroma kapcsán Menandros Protéktór leírja: az avarok azt színlelték, hogy a szlávokra támadnak a Száván túl, és nem Sirmiumot akarják bevenni (MENANDros PROTÉKTóR 471, 25-476, 25. vö. SZÁdECZKY-KARdOSS 1998, 47-48). Egy kései forrásunk, Kónstantinos Porphyrogennétos munkájában található, hogy az avarok miként vették be Salonát: a foglyul ejtett salonaiak ruháját öltötték fel, és így akadálytalanul bejutottak a városba. ${ }^{355}$

Az ostromgépekröl az írott forrásokban Thessalonike 597-es (vagy 586-ban), 618as és Konstantinápoly 626-os ostroma kapcsán találunk részletes jellemzést. E téma vizsgálata kapcsán legfontosabb forrásunk a Miracula S. Demetrii, a Chronicon Paschale, valamint Theophylaktos Simokattés, Theodóros Synkellos és Geórgios Pisidés munkája. A forrásokban több esetben csak az ostromgépekre általában vonatkozó kifejezések találhatók, melyek nem jelölnek konkrét típust: így ' $\varepsilon \lambda \varepsilon \dot{\pi} \pi \mathrm{o} \lambda \mathrm{s}$ (MIRACULA S. DEMETRII I.

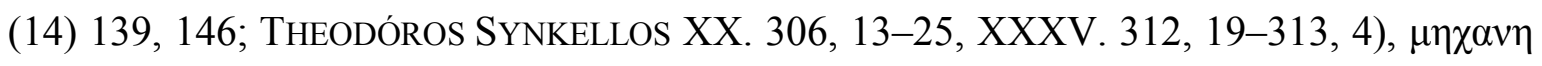
(Miracula S. DemetriI I. (14) 145; Theodóros Synkellos XXXV. 312, 19-313, 4), és $\mu \alpha \gamma \gamma \alpha v i \kappa \alpha$ (Miracula S. Demetrit II. 2. 211; Chronicon PASCHALE 719, 16-721, 4; 724,

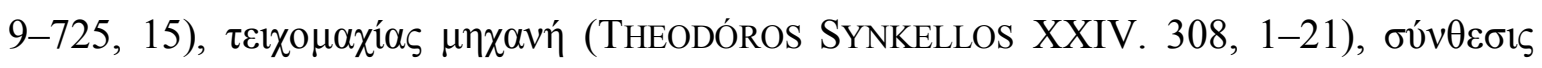
(GEÓRGIOS PISIDÉS 197-225) terminust találunk. Emellett a korabeli szerzők több esetben említenek különféle ostromgéptípusokat, úgy, mint hajítógép, ostromtorony, faltörő kos, ostromtető, ostromlétra, lánggyújtó szerkezet, karók.

Theodóros Synkellos munkájából kiderül, hogy ezeket az ostromgépeket helyben készítették, és a felépítésükhöz szükséges faanyagot az adott környékről szerezték be. A nehezen elkészíthető, bonyolult alkatrészeket viszont szekereken szállították a helyszínre (TheOdóRos SynKellos XX. 306, 13-25. vö. SZÁDECZKY-KARDOSS 1998, 187). A

\footnotetext{
${ }^{353}$ Ratiaria, Bononia, Aquae, Durostorum, Zaldapa, Panassa, Marcianopolis, Tropaeum (THEOPHYLAKTos SiMOCATTÉs I. 8, 1-11. vö. SZÁDECZKY-KARDOSS 1998, 65).

${ }^{354} \mathrm{Az}$ árulásért a friauli herceg felesége csúnyán megfizetett, ugyanis az avar kagán nem tartotta be a szavát, megkínoztatta és megölette (PAUlus DiACONUS IV. 37-38. vö. SZÁDECZKY-KARDOSS 1998, 148-149).

${ }^{355}$ Ezen forrás esetében megjegyzendő, hogy az említett események után jóval később keletkezett, és kortárs forrás sem erősíti meg a történteket, így nem tekinthető teljesen hitelesnek a csel leírásának története. Szádeczky-Kardoss Samu ezt a viseletcserés cselt novellisztikus elemnek, irodalmi színezésnek tartja (SZÁDECZKY-KARDOSS 1998, 152-153).
} 
helyben történő felépítést támasztja alá az is, hogy az ostrom harmadik vagy negyedik napján vetették be elöször ezeket a gépeket (MiRACULA S. DEMETRII II. 2. 202-203, Chronicon Paschale 719, 5-725, 15, Theodóros Synkellos XX. 306, 13-25. vö. SzÁDECZKY-KARDOSS 1998, 159, 184, 187). ${ }^{356}$ Theodóros Synkellos leírása szerint ezeket a szerkezeteket nagyon gyorsan és gördülékenyen szerelték össze (THEODÓROS SYNKELlOS XX. 306, 13-25. vö. SzÁDECZKY-KARDOSS 1998, 187). Sikertelen ostrom esetén a gyors elvonulás miatt nem vihették őket magukkal, viszont az ellenségre sem akarták ráhagyni. A Chronicon Paschale-ból és Theodóros Synkellos munkájából tudjuk, hogy elvonulás előtt az ostromgépekről leszedték a nyúzott bőrt, és elégették a faszerkezeteket (Chronicon PASCHALE 724, 9-725, 15, THeOdóros SynKellos XXXV. 312, 19-313, 4. vö. SzÁDECZKY-KARDOSS 1998, 185, 188). Arra, hogy az avar hadsereg egy-egy város ostromára mennyi időt fordított, kevés adatot találunk a forrásokban. A sikeresen bevett városok közül csak Sirmium esetében jelöli a forrás az ostromra fordított időt. Az avar hadseregnek két évébe telt a város elfoglalása (Iohannes Ephesinus VI. 30 32. vö. SZÁDECZKY-KARDOSS 1998, 50). A sikertelen ostromok közül három esetben említik az időintervallumot: ez Thessalonike első ostromakor hét nap, második ostromakor valamivel több, mint egy hónap volt (MiRACUla S. DEMETRII I. (14) 157, II. 2. 213. vö. SzÁDECZKY-KARDOSS 1998, 116, 160), Konstantinápolyt pedig tíz napig ostromolták (TheOdóRos Synkellos XXV. 308, 22-36. vö. SZÁDECZKY-KARdoss 1998, 187). Valószínüleg a Bizánci Birodalom határainál még megengedhette magának az avar hadsereg, hogy ilyen hosszú ideig ostromoljon egy várost, mint például Sirmiumot. ${ }^{357}$ A birodalom belsejében azonban, ahová a bizánci seregeket is könnyebben lehetett mozgósíthatni, az avar hadsereg kénytelen volt hirtelen meglepetésszerü lerohanással és (vagy) ostromgépek bevetésével gyorsítani az ostromot, sikertelenség esetén pedig inkább elvonulni.

\section{A hajitógépek}

Az avar hadsereg hajítógépeiről három forrás tesz említést négy különböző terminussal

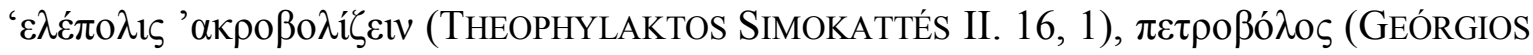
PisidÉS 719, 16-721, 4; MirACULA S. DEMETRII I. (14) 139, 146, 150, 151, 153; II. 2. 203,

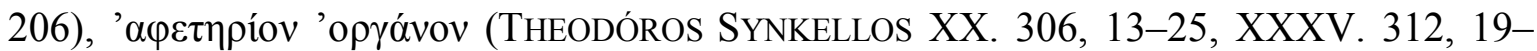

\footnotetext{
${ }^{356} \mathrm{Az}$ a lehetőség, hogy az avarok a hadjárataik során végig vonszolták volna az ostromgépeiket az egész Balkánon, nem tekinthető reálisnak. Ez nagyon elnyújtotta volna hadsereg vonulási idejét.

${ }^{357}$ Sirmium ostromakor a bizánci császárnak nem állt rendelkezésére szabad mozgósítható egység, mivel a perzsák elleni front a hadsereg nagy részét lefoglalta.
} 


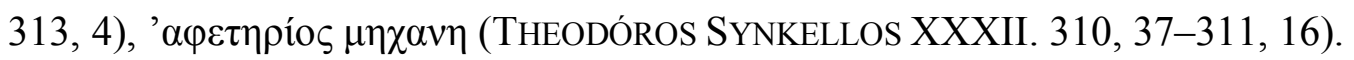

A hajítógéptípusok közül kettő hozható kapcsolatba az avarokkal. Mint a hunokról szóló fejezetben már utaltam rá, az ókori és a kora középkori Európában torziós hajítógépeket használtak, ezek közül megfigyelhetők a nyílvesszőt, követ, sőt gyújtószerkezetet kilövő szerkezetek is [22., 23. kép] (LÁSZLÓ 1909, 779; MARSDEN 1969, 24-33; BenNETT 2001, 33, 61). Több kérdést vet fel a Kínában feltalált hajítógéptípus megjelenése Európában. Két változata közül az egyszerübb szerkezetủ hajítógép hozható közvetlenül kapcsolatba a Bizánci Birodalmat támadó avarokkal: ${ }^{358}$ a hajítógép parittyájában lévő kőlövedéket a kar másik végén lelógó kötelek meghúzásával több katona tudta kilőni. Ez az eszköz a torziós szerkezeteknél nehezebb lövedékeket tudott elhajítani, bár hatótávolsága és a pontossága rosszabb volt a torziósokénál [24. kép] (HILL 1973, 99-100; MCCOTTER). D. R. Hill szerint ez a típus csak a 7. század végén, arab közvetítéssel került Európába (HILl 1973, 99-100). M. Bennet szerint viszont már jóval korábban, az 5. században eljutott kontinensünkre ez a szerkezet (BENNETT 2001, 321).

A torziós gépek használatáról az avarok esetében Theophylaktos Simokattés tesz említést, miszerint Appiareia ostromakor 587 táján az avarok elfogtak egy Busas nevü katonát, aki megtanította őket ostromgépek készítésére (THEOPHYLAKTOS SIMOKATTÉS II. 16, 1. vö. SzÁDECZKY-KARDOSS 1998, 69). A szerző pontosan lejegyzi a Busas által elkészített ostromgép típusát, vagyis a hajítógép (' $\varepsilon \lambda \varepsilon \dot{\pi} \pi \circ \lambda ı{ }_{1 \varsigma}$ ' $\alpha \kappa \rho \circ \beta о \lambda i \zeta \zeta \varepsilon v$ ) szerkezeti felépítését sajátították el az avarok szerinte (THEOPHYLAKTOS SIMOKATTÉS II. 16, 1). Mivel ebben az időszakban a torziós hajítógépek használata terjedt el széles körben a Bizánci Birodalomban, így ez a forrás a torziós gépek avar átvételére vonatkozhat. Míg Lampert, Vryonis és Kardaras elfogadta Theophylaktos azon híradását, hogy a „barbárok” a bizánciaktól tanulták meg ezt az ostromtechnikát (LAMMERT 1938, 409; VRYONIS 1981, 378-390; KARDARAS 2005, 60), addig Whitby és Whitby nyomán McCotter azon a véleményen volt, hogy a munka szóban forgó részletének forrásértéke erősen kétséges arra vonatkozóan, hogy az avarok ekkor sajátították volna el az ostromgépek készítését a bizánciaktól. Véleményük szerint egyrészt már a Bizánci Birodalom elleni támadások elött is jártasak lehettek az avarok e technikákban, másrészt már korábban is, legalább 578-tól hozzáférhettek a bizánci hadmérnökség vívmányaihoz (WHITBY 1988, 118; MCCOTTER). ${ }^{359}$ Akár elfogadjuk, akár elvetjük azt a lehetőséget, hogy az avarok 587-ben vehették át ennek

\footnotetext{
${ }^{358}$ Másik típusa, az ellensúllyal rendelkező hajítógép csak a 12. század végétől terjedt el [25. kép] (LÁszLó 1909, 779; Hill 1973, 103).

${ }^{359}$ Emellett azonban felmerül az a kérdés is, hogy vajon egy átlagos bizánci katona képes volt-e elkészíteni egy viszonylag bonyolult szerkezetű torziós gépet.
} 
az ostromgéptípusnak a használatát, a forrás legfontosabb információtartalma az, hogy az avarok bizánci hatásra torziós hajítógépeket (is) használtak.

Az avarok hajítógéptípusainak a vizsgálatába Theophylaktos fent említett részlete mellett érdemes bevonni egy másik forrást is. A Szent Demeter csodáiban is fellelhető egy, az avarok által használt hajítógép típus. A forrás nagyon részletesen leírja a gépezet szerkezetét: „A kőhajítógépek négyszögüek voltak, a szélesebb alapzattól a keskenyebb csúcsok felé elvékonyodóak. Itt, a tornyok tetején helyezkedtek el a két végükön erősen megvasalt zömök hengerek. Eme hengerekre nagy házgerendákhoz hasonló fa alkatrészeket szegeztek. Ezek hátul felerösítve a parittyaszerü kőtartókat hordozták, elöl pedig azokat az erős köteleket, amelyekkel lehúzva és megfeszítve a levegőbe kiröpítették a sivítva elszálló köveket" (MIRACUla S. DEMETRII I. (14) 151. ford. SzÁDECZKYKardoss 1998, 116). Whitby és McCotter szerint a Miracula S. Demetrii-ben található részletes leírás az egyszerübb kínai típusú hajítógépekre vonatkozik (WHITBY 1988, 118;

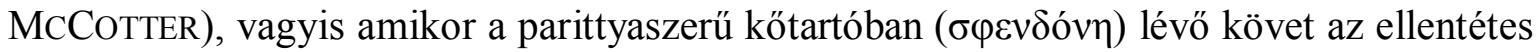

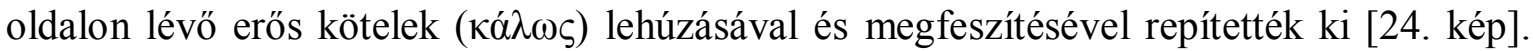
Whitby és McCotter nem tartják kizártnak, hogy ez az addig még Európában ismeretlen ostromgéptípus elterjedése az avarokkal hozható összefüggésbe. A forrásból kiderül, hogy az avar hadsereg Thessalonike ostromakor nagy valószínűséggel ezt az egyszerübb felépítésủ hajítógépet használhatta, az viszont kétséges, hogy ennek az ostromgéptípusnak a megjelenése Európában valóban az avarokhoz köthető-e. A közép bizánci korszakban a bizánci hadtudományi irodalom keveset foglalkozott az ostromtechnikával, Maurikios is csak röviden, általánosságban értekezik e témáról (MAURIKIOS X. 1, 3. vö. DennisGamillscheg 1981, 337-341, 343-347; TőSÉR 2006 459). Ennek ellenére a haditaktikában jártas császár valószínűleg hangsúlyozta volna az avarok jellemzése kapcsán, hogy más újítások (például zászlóval ellátott kopja, nyakvédő, szügyvért, sátor ${ }^{360}$ ) mellett ezt a bizánciak számára ismeretlen hadigéptípust is át kellene vennie a bizánci hadseregnek az avaroktól. Ezzel szemben pont egy toposzt emel ki az avarok kapcsán azzal, hogy erődített helyekkel szemben csak a kiéheztetés taktikáját ismerik. Viszont Whitby és McCotter elmélete mellett szól az megállapítás is, hogy ez az egyszerübb szerkezetủ hajítógéptípus ebben a forrásban, az avarok kapcsán tünik fel elöször a bizánci irodalomban. Akár az avaroktól vették át a bizánciak ezt a hajítógéptípust, akár nem, az avarok a gép felépítésének a tudását keletről hozhatták magukkal. 360 Az avarok sátrára vonatkozó ismereteket lásd SZÁDECZKY-KARDOSS 1986, 212-213; SZÁDECZKY-
KARDOSS 1998, 80-81; ANDREWS 1999, 1273-1274; NAGY 2012, 185-195. 
Az avarok hajítógépeire vonatkozó kifejezések közül jó kora középkori és ókori

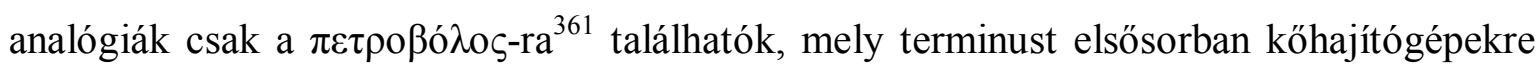
használtak (MARSDEN 1969, 1, 61-62, 70). ${ }^{362}$ A Miracula S. Demetrii-ben konkrétan

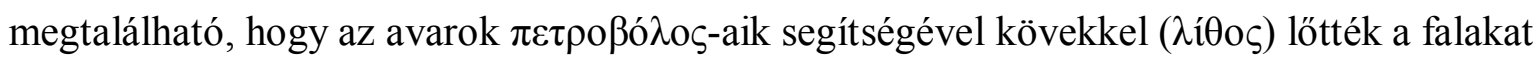
(Miracula S. Demetri I. (14) 139, 151, 155; II. 2. 206). A többi terminusból nem lehet egyértelmüen eldönteni, hogy kő- vagy nyíllövőgépre utal a forrás. Ez azért is nehezen dönthető el, mert némelyik torziós hajítógépet egyaránt nyíl és kő kilövésére is alkalmazhatták az ostromlók a források szerint (MCGEER 1991, 195). Visszatérve a Miracula S. Demetrii részletes jellemzésére, a leírásból kiderül, hogy ezek a szerkezetek fából készültek, négyszögletes alakúak, az ostromlott város felőli oldalán deszkákkal kerítették be őket, ami védelmül szolgált az ostromgép müködtetőinek. Szintén ez a forrás említi, hogy ezek a szerkezetek magasabbak voltak a városfalaknál. A hajítógépet az ostromlottak tűzcsóvái és fortyogó szurokja ellen frissen leölt marhák és tevék bőrével fedték be (Miracula S. DEMETRII I. (14) 151; II. 2. 203. vö. SZÁdECZKY-KARDOSS 1998, 116, 159). A kőhajítógépek szerepe a városfalak és az ostromlott település egyéb épületeinek megrongálása volt (MARSDEN 1969, 86-87). ${ }^{363}$ A kőhajítógépek számára vonatkozólag Miracula S. Demetrii-ben találunk utalást, miszerint Thessalonike avar ostromakor a város keleti oldalán ötvennél is több kőhajítógép volt felállítva (MIRACULA S. DeMETRII I. (14) 154. vö. SzÁdECZKY-KARdOSS 1998, 116). Egy kései forrás, Iohannes Stauracius szerint Thessalonike ostrománál tízezernyi hajítógépet vetettek be (Iohannes Stauracius (12) 22. vö. SZÁDECZKY-KARDOSS 1998, 120). Ez a szám azonban erősen túlzó, nem tekinthető hitelesnek. Fontos kérdés, akárcsak a hunok esetében, hogy vajon ezeket a szerkezeteket magukkal hozhatták-e az avarok, vagy pedig helyben építették fel őket. A Szent Demeter csodáiból következtethetünk arra, hogy ezeket a szerkezeteket a városfalaktól távol építették fel, és később vontatták a falakhoz (MIRACULA S. DEMETRII I. (14) 139, 146. vö. SzÁDECZKY-KARDOSS 1998, 115). A hajítógépek bevetésének a

\footnotetext{
${ }^{361}$ Latin megfelelöje a ballista kifejezés (MARSDEN 1969, 1).

${ }^{362}$ A 6. század közepén keletkezett, egy ismeretlen szerző által készített hadászati munkában is a $\pi \varepsilon \tau \rho o ß o ́ \lambda o \zeta-t$ elsősorban kőhajítógépnek nevezték (ANONYmus 12. 5, 13. 58, 13. 115. vö. Dennis 1985, 3435, 40-41, 42-43), bár néhány esetben tüzgyújtó lövedékeket kilövő szerkezetként is említi az ismeretlen szerző (ANONYMUS 19. vö. Dennis 1985, 63). A kortárs Maurikios munkájában azonban egy helyen a $\pi \varepsilon \tau \rho o \beta o ́ \lambda o \varsigma$-t nyílvetőgép használatban is említi a bizánci szerző (MAURIKIOS X. 1, 52, 55. vö. Dennis-

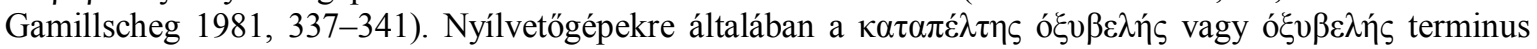
található a görög nyelvü forrásokban, a latin forrásokban pedig catapulta terminussal jelenik meg ez az ostromgéptípus (MARSDEN 1969, 188).

${ }^{363}$ A kortárs Maurikios kiemeli a hajitógépek hatásosságát különösen akkor, ha az ostromlott város/vár földrajzi elhelyezkedése folytán nem ostromolható fatornyokkal, faltörő kosokkal (MAURIKIOS X. 1, 52, 55. vö. Dennis-Gamillscheg 1981, 337-341).
} 
módszerére Theodóros Synkellos munkájában találunk utalást, a szerző szerint Konstantinápoly ostromakor a hajítógépeket egyszerre hozták müködésbe, így a lövedékek áradatával támadták a várost (THEODÓROS SYNKELLOS XXXII. 310,37-311,16. vö. SZÁDECZKY-KARDOSS 1998, 188). ${ }^{364}$

\section{Az ostromtornyok}

Az avarok ostromgépei közül az ostromtornyokat is több szerző említi $\pi u ́ \rho \gamma o \varsigma$ (Theodóros Synkellos XX. 306, 13-25, XXXV. 312, 19-313, 4; Chronicon PASChale 719, 16-721, 4, 724, 9-725, 15; GeÓRgiOS PISIDÉS 222; MirACULA S. DEMETRII II. 2. 203) és $\xi v ́ \lambda o \pi v ́ \rho \gamma o \varsigma$ (Miracula S. Demetrii II. 2. 211) terminussal.

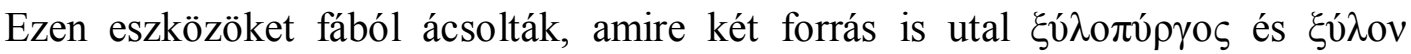
kifejezéssel (Miracula S. DemetriI II. 2. 203, 211; Theodóros SynKellos XXXV. 312 , 19-313, 4). Az írott források információi alapján megállapítható, hogy magasságuk körülbelül a városfalak magasságával egyezett meg, illetve a hajítógépekhez hasonlóan bőrökkel fedték be öket az ellenfelek gyújtófegyverei ellen (MIRACULA S. DEMETRII II. 2. 203, Chronicon Paschale 719, 16-721, 4. vö. SzÁdeczKy-Kardoss 1998, 159, 184). Szintén a Szent Demeter csodáiból tudjuk, hogy ezeket az ostromtornyokat különböző

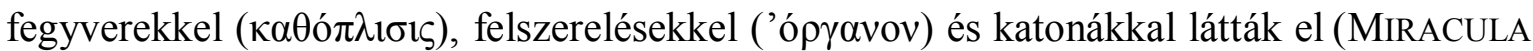
S. DEMETRII II. 2. 211). Arra azonban nem ad konkrét választ a forrás, hogy egy- vagy többszintesek voltak-e ezek a tornyok, és hogy milyen felszerelésekkel és fegyverekkel rendelkeztek. Valószínüleg többszintesek lehettek, erre utal a magasságukra vonatkozó leírás (közel egy szintben voltak a városfallal vagy magasabbak voltak), s nehezen képzelhető el, hogy ilyen magas tornyoknak csak a tetejét használták volna ki. Korábbi latin források is arról tanúskodnak, hogy ezek az ostromtornyok több emelettel rendelkeztek, és minden szintnek megvolt a sajátos szerepe az ostromban (MARSDEN 1969, 188, 198). ${ }^{365}$

$\mathrm{Az}$ ostromtornyok bevetésével a tornyok magasságának köszönhetően sokkal

\footnotetext{
${ }^{364}$ Maurikios írja le, hogy az ostromlottak a kőhajítógépek ellen bőrből, zsákból készült anyagot akasztottak a falakra, mellvédekre, hogy ezek tompítsák a kilőtt kövek ütéseit (MAURIKIOS X. 3, 9, 17. vö. DennisGamillscheg 1981, 343-347). A 6. századi ismeretlen szerző szerint ugyanemiatt újnyi vagy attól vastagabb kötélböl készült hálót akasztottak a falra (ANONYMus 13. 115. vö. Dennis 1985, 43).

${ }^{365}$ A hunokkal foglalkozó fejezetben már utaltam Vegetius munkájára, amelyböl kiderül, hogy az ostromtornyok alsó részén faltörö kos müködik, felsőbb részein lándzsások, íjászok, parittyások támadásával, és kisebb hajítófegyverek bevetésével vették fel a harcot a városok védőivel (VEGETIUS IV. 17, 21. vö. Várady 1963, 751-865, 848, 850).
} 
könnyebben vehették fel a harcot a városfalakon harcolókkal. ${ }^{366}$ Szintén a Szent Demeter csodáiból tudjuk, hogy az ostromtornyokat a falaktól távol ácsolták össze, és ezután vontatták őket a falak mellé (Miracula S. DemetriI I. (14) 139; II. 2. 203. vö. SZÁdECZKY-KARDOSS 1998, 115, 159). A Chronicon Paschale-ben Konstantinápoly ostroma kapcsán említik a fatornyok számát, eszerint az avarok tizenkét ostromtornyot építettek (CHRONICON PASCHALE 719, 16-721, 4. vö. SzÁDECZKY-KARDOSS 1998, 184).

\section{A faltörö kos}

Az avar hadsereg faltörőkos használatára kizárólag a Miracula S. Demetrii-böl

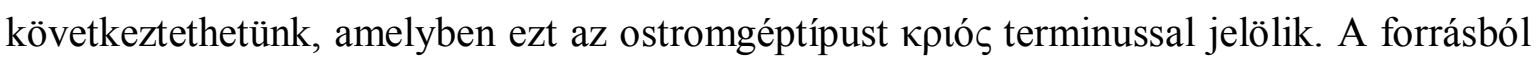
kitünik, hogy fából készültek ( $\xi u ́ \lambda o v)$, és a fejrészük vassal ( $\sigma i ́ \delta \rho o \varsigma)$ volt beborítva (Miracula S. DeMETRII I. (14) 139, 146, II. 2. 203). ${ }^{367}$ Ezek a faltörő kosok általában fel voltak függesztve egy-egy keretbe, ${ }^{368}$ amelyből lengtek elöre-hátra a célponttal szemben (MCGEER 1991, 195). ${ }^{369}$ Ezt támasztja alá az avarok kapcsán a Thessalonike 618-as ostroma kapcsán tett megjegyzés, miszerint gördülö kerekeken ( $\tau \rho \circ \chi o ́ \varsigma)$ vontatták őket a kapuhoz (Miracula S. DemetriI II. 2. 203). A Szent Demeter csodáiban azonban nem találunk utalást arra, hogy a faltörő kosok kezelöit védte volna-e valami az ostromlottaktól. ${ }^{370}$ Hasonlóan más hadiszerkezetek kezelőihez valószínűleg ezeket az ostromlókat is ostromtetők vették körül az avarok esetében, vagy esetleg egy-egy ostromtorony alsó szintjére helyezték el őket. Az ilyen típusú ostromgépet elsősorban a városkapuk betörésére (MCGEER 1991, 195) és esetleg a falak megrongálására

\footnotetext{
366 Maurikios is kiemeli az ostromtornyok hatásosságát az ostromok kapcsán. Úgy véli, hogy a gyújtólövedékekkel, kőhajítógépekkel és ellentornyok építésével lehet védekezni ellenük (MAURIKIOS X. 3. 17, 19, 22. vö. Dennis-Gamillscheg 1981, 343-347).

${ }^{367}$ Josephus Flavius Kr. u. 1. századi szerző a Zsidó háború címủ munkájában részletesen jellemzi ezeket a faltörő kosokat, melyek nem sokban különbözhettek az avar kori ostromeszközöktől. A szerző leírja, hogy ennek az ostromgéptípusnak az alapját egy hajóárbochoz hasonló hatalmas gerenda képezte, amelynek az elején egy kosfej alakú erös vasveret van (Josephus Flavius III. 7. vö. Révay 1999, 269). Hasonlóan jellemzi a faltörő kosokat a 4. század második felében Ammianus Marcellinus is, aki szerint ezek az ostromgépek hosszú fenyö- és kőrisfából készülnek, és az első részüket erös vasba foglalják (AMMIANUS MARCELlinUS XXIII. 4. vö. Szepesy 1993, 325-326).

368 Josephus Flavius és Ammianus Marcellinus leírásából kitünik a keretbe foglalt, ezáltal előre-hátra lengethető faltörö kosok használata (JOSEPHUS FlavisuS III. 7. vö. Révay 1999, 269; AMMIANUS MARCELLINUS XXIII. 4. vö. Szepesy 1993, 325-326). Hasonló szerkezetű faltörö kosokról számol be a 6 . századi ismeretlen szerző is (ANONYMUS 13. 121-135. vö. Dennis 1985, 42-43).

${ }^{369}$ Maurikios leírja a faltörő kosok elleni védekezést, miszerint homokkal, szalmával megtömött zsákokat kell a célpont elé lelógatni, ami tompítja a faltörö kosok ütéseit (MAURIKIOS X. 3, 12. vö. DennisGamillscheg 1981, 343-347).

370 Josephus Flavius írja le, hogy a faltörő kosokat és kezelőiket vesszőfonattal vették körül, és marhabőrökkel vonták be a fegyver tetejét (JoSEPHUS FLAVISUS III. 7. vö. Révay 1999, 269-270).
} 
alkalmazták. ${ }^{371} \mathrm{Az}$ avarok esetében Thessalonike ostroma kapcsán a forrás jelzi, hogy a faltörő kosokat a kapuk ellen építették, egy esetben konkrétan említik, hogy a Kas(s)andreiai Kapu ellenében vetették be ezt az ostromeszközt (MIRACULA S. DEMETRII I. (14) 146. vö. SZÁDECZKY-KARDOSS 1998, 115).

\section{Az ostromtetö}

A városostrom szempontjából szintén fontos szerkezet volt az ostromtető, melyet egységesen $\chi \varepsilon \lambda \omega ́ \vee \eta$ terminussal jelölnek a korabeli szerzők az avarok kapcsán (MIRACULA S. DemetriI I. (14) 139, 146, 147, 148, 150, II. 2. 203, 211; TheOdóROS SyNKellos XVIII. 305, 13-36, XXXV. 312, 19-313, 4; Chronikon PAschale 719, 5-16, 724, 9725, 15; GEÓRgIOS PISIDÉS 221).

Ezek az ostromtetők faágakból ( $\rho \alpha ́ \beta \delta o \varsigma)$ épültek fel, és nyers marha- vagy tevebőrökkel fedték le öket, hogy az ellenség tüzfegyvereitől megvédjék öket (MIRACULA S. DemetriI I. (14) 146; II. 2. 203). A Szent Demeter csodáiból az tünik ki, hogy ezek az ostromtetők - vagy ahogy a források említik: teknőcpáncélok - olyan, csapatok által hordozott védtetők voltak, amelyek a falhoz közeledő ostromlókat védték a városbeliek lövedékeitől. Az ostromtető alatt a fal mellett védetten tudták megrongálni a falalapzatot

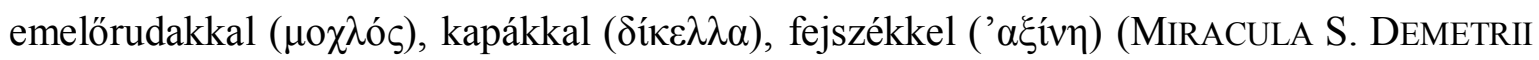
I. (14) 147,150$).{ }^{372}$ E szerkezetek száma Thessalonike ostroma esetében a Miracula $S$. Demetrii szerzője szerint ezernél is több lehetett (MiRACUlA S. DEMETRII I. (14) 139). Theodóros Synkellos leírásából is nagyszámú ostromtetőre következtethetünk. Szerinte Konstantinápoly ostromakor az avarok az ellenfelek közötti területet telerakták ostromtetővel, így teljesen védettek voltak a várbeliekkel szemben (THEODÓROS SYNKELLOS XVIII. 305, 13-36).

\section{Az ostromlétra}

Az avar hadsereg ostromlétra-használatára csupán egyetlen forrás utal, amelyben $\kappa \lambda i ́ \mu \alpha \xi$

\footnotetext{
${ }^{371}$ Josephus Flavius és Ammianus Marcellinus, valamint egy 6. század közepén keletkezett ismeretlen szerző által készített hadászati munka is megemlíti, hogy a falak megrongálására alkalmazták a faltörö kosokat (Josephus FlaVius III. 7. vö. Révay 1999, 269-270; AMmianus MARCELlinus XXIII. 4. vö. Szepesy 1993, 326; ANONYMus 12. vö. Dennis 1985, 34-35).

${ }^{372}$ Vegetius is hasonlóan jellemzi a „teknősöket”, a szerző ezenkívül két speciális típust is megnevez. Az egyik esetben a teknős belsejébe egy gerendát helyeznek, és a hegyére horgas vasat erősítenek, amivel ki tudták fejteni a köveket a falakból. A másik esetben a gerenda hegyét vassal borítják be, és így próbálják a falakat betörni (VEGETIUS IV. 14. vö. Várady 1963, 846). Az avarokra vonatkozó forrásokból azonban ezekre nem lehet következtetni. A 6. század közepén íródott bizánci hadászati munka is megemlíti a $\chi \varepsilon \lambda \omega ́ v \eta-k a t$, melyek segítségével az ostromlók védve voltak közvetlenül a falak mentén a várbeliek támadásaitól (ANONYMUS 13. vö. Dennis 1985, 38-39).
} 
terminussal jelölik az eszközt (Miracula S. DeMETRII II. 2. 203). Ennek ellenére valószínüsíthető, hogy használatuk általános lehetett az avar ostromok esetében, mivel könnyen elkészíthetők voltak, és a hajítógépek rombolása után a falat ostromló katonák elengedhetetlen eszközének tarthatjuk ezeket. Ezek a szerkezetek fából készültek, és

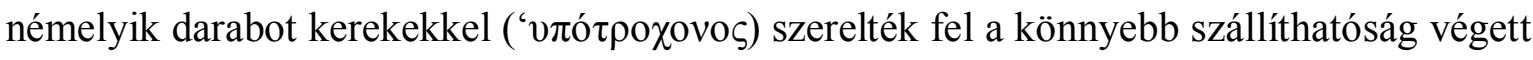
(Miracula S. DemetriI II. 2. 203). A létrák egyértelmüen a városfalak megmászásában nyújtottak segítséget. ${ }^{373}$

\section{Egyéb eszközök}

A Miracula S. Demetrii-ben található egyetlen egy helyen egy kifejezés, mely lánggyújtó szerkezetre utal ( $\delta i \alpha ́ \pi v \rho \circ \varsigma \mu \alpha \gamma \gamma \alpha v \varepsilon i ́ \alpha)$, amely az ostromlott város faszerkezetủ részeinek a felgyújtására szolgált (MIRACULA S. DEMETRII II. 2. 203). A forrásból nem lehet eldönteni, hogy milyen típusú lánggyújtó szerkezetről van szó. ${ }^{374}$

Szintén a Miracula $S$. Demetrii-ben található egy feljegyzés, miszerint Thessalonike ostromakor az ostromlók karókat ('ó $\rho \pi \eta \xi)$ szögeztek le (MIRACULA S. DEMETRII II. 2. 203). Ezeket a nyársszerü, kihegyezett karókat leszögelés után valamivel általában letakarták, hogy az ellenfél ne vegye észre, és beleesve felnyársalódjon. Ezt a csapdát az ostromlók azért állíthatták fel, hogy az ostromeszközeiket a várbeliek esetleges kirohanásai ellenében ily módon is biztosítsák (SzÁDECZKY-KARDOSS 1998, 161).

Tenger- vagy folyóparti települések esetében az avar hadsereg a vízfelületeken is próbált támadni. Sirmium bevételekor a Száván épített híd meggátolta az „élelem és más támogatás" bevitelét a városba (MENANDROS PROTÉKTÓR 471, 25-476, 25. vö. SZÁDECZKY-KARDOSS 1998, 47-48). Thessalonike első ostromakor fapadozatot és fajárdát ( $\xi u ́ \lambda ı v o \varsigma \gamma \tilde{\eta} \kappa \alpha \iota \pi \lambda \alpha \tau \varepsilon \tilde{\imath} \alpha$ ) próbáltak a tengerre fektetni, és így az öblön keresztül is támadást intézni a város ellen (Miracula S. DEMETRII I. (14) 145). Theodóros Synkellos szerint

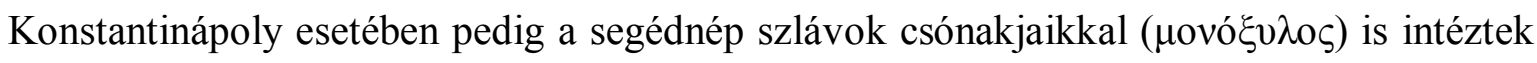
támadást a város Aranyszarv-öböl felöli részén (THEOdóROS SYNKELLOS XXIV. 308. 121).

\footnotetext{
${ }^{373}$ Szintén Vegetius írja le, hogy az ostromlétrákat általában akkor vetik be az ostromlók, miután az íjászok, parittyások, hajítógépek kezelői visszaszorítják a falakról a védőket (VEGETIUS IV. 14. vö. Várady 1963, 846). Maurikios is hangsúlyozza, hogy az ostromlétrák bevetése abban az esetben indokolt, ha a tüzgyújtó lövedékek használatát követően az ostromlottak a tüz eloltásával vannak elfoglalva (MAURIKIOS X. 1, 13. vö. Dennis-Gamillscheg 1981, 337-341).

${ }^{374}$ A gyújtólövedékek két típusa különíthető el. A malleolus esetében égő nyílhegyet lőnek ki a célpontra. A phalarica esetében a dárda hegyét olajjal öntik le, és a lándzsahegy köpüjét gyantával, szurokkal, ronggyal borítják be. Ha így lövik ki ezeket a dárdákat, képesek áthatolni a nedves bőrön, és égve hatolnak be a fába (LÁSZLÓ 1909, 778).
} 


\section{2. 4. Az alávetett segédnépek szerepe}

Az avar hadsereg vizsgálata kapcsán megállapítható, hogy a bizánci-avar háborúk időszakában találhatók meg főként és nagy számban a forrásokban az avarok segédnépei. A Bizánci Birodalom elleni hadjáratok időszakára jellemző a legnagyobb forrásbőség az Avar Kaganátus esetében, több népet is megemlítenek az auktorok. A 7. század második felét követően viszont már egyáltalán nem figyelhetők meg az írott forrásokban az avar hadsereg segédnépei. ${ }^{375}$ A bizánci-avar háborúk időszakában görög nyelvü auktorok müvei állnak rendelkezésünkre, de emellett néhány latin nyelvü forrás is utal az avarok segédnépeire. Az avarok segédcsapatait néhányszor a csata/hadjárat leírása esetében említik a kútfök, és néha konkrétan a harcmodorukra is utalnak az auktorok. Leggyakrabban az Avar Kaganátus kialakulásakor és felbomlásakor beolvadó, illetve kiváló népekre utalnak a források a segédnépek kapcsán. Az avar segédcsapatokat több csoportba sorolhatjuk: megfigyelhetőek közöttük életmód alapján nomád (elsősorban török nyelvü) és letelepült (germán, illetve szláv nyelvü) népek. A vizsgált alávetett népek esetében megállapítható, hogy az avar hadsereg hadi repertoárját számos - a korábbi sztereotípiák szerint egyébként a nomád népekre nem jellemző - taktikai elemmel (úgy, mint nehézfegyverzetű és könnyüfegyverzetű gyalogság, valamint az erődített városok szárazföld és folyó/tenger felőli ostroma) gazdagították. Emellett a segédnépek bevetése kockázattal is járt: Maurikios írja azt az avarok hadseregéről, hogy nagymértékben meggyengíti az alávetett népek ellenséghez történő átpártolásának lehetősége (MAURIKIOS XI. 22-23. vö. SZÁDECZKYKARDOSS 1998, 83). Erre utal Theophylaktos Simokattés híradása is, mely szerint 602-ben az avar hadseregből több egység elpártolt és átállt a bizánci császárhoz (THEOPHYLAKTOS SIMOKATTÉS VIII. 6, 1-8. vö. Olajos 2012, 277). ${ }^{376}$

\footnotetext{
${ }^{375}$ A régészeti anyagban is tetten érhető ez a sokszínűség. Az avar honfoglalással nem egy egységes homogén kultúra bontakozott ki a Kárpát-medencében. A különböző kultúrköröknek az írott forrásokban feltünő népekkel történő azonosítása - annak ellenére, hogy számos kísérlet történt erre vonatkozólag eléggé nehézkes és problematikus (BÁLINT 1995, 262-319; BÁLINT 2010, 160-161). Többnyire ezek a próbálkozások nem vezettek eredményre. Lásd a következő lábjegyzetekben az alávetett segédnépek régészeti anyaghoz kötéséhez történő kísérleteket. Az avar honfoglalást követően körülbelül száz évvel homogenizálódik, egységesül a leletanyag (BÁLINT 2010, 160-161). Tomka Péter szerint a késő avar kor kultúrájának ez az egységessége csak látszólagos, politikai hatásnak tekinthetö, nem pedig „etnikai” uniformizálódásra vezethetỏ vissza (TOMKA 1990, 173).

${ }^{376}$ Olajos Terézia ezzel az eseménnyel kapcsolatban felveti annak a lehetőségét, hogy az avar csapattestek dezertálása csel lehetett, és a céljuk a bizánci hadsereg hadrendjének felbontása, fellazítása volt (OLAJOS 1977, 9; OlAJOS 2012, 277).
} 


\section{2. 4. 1. Nomád segédnépek}

Az avarok délorosz steppei vándorlása során Theophylaktos Simokattés és Menandros Protéktór leírása alapján a szabir, ${ }^{377}$ onogur, ${ }^{378}$ kutrigur és utigur ${ }^{379}$ nomád népeket hódoltatták meg (MENANDROS PROTÉKTÓR 196, 26-198, 10, 444, 28-443, 9, vö. SzÁdECZKY-KaRdoss 1998, 19-20. 38; THeOPhYlaKtos SimoKATtÉS VII. 8, 1-5. vö. Olajos 2012, 246-247; POHL 1988, 39-40; SZÁDECZKY-KARDOSS 1994, 207; SZÁDECZKYKARDOSS 1996, 21). E népek közül a szabirokra és utigurokra vonatkozó adatokat már nem találunk a későbbiek folyamán az Avar Kaganátus történetével kapcsolatban. Ennek ellenére mégsem zárható ki teljesen, hogy a szabirok és az utigurok szolgáltak volna az avar hadseregben, kisebb egységeik jelen lehettek, de nem tölthettek be jelentősebb szerepet az avarok hadseregében. A kutrigurokra valamivel több adat áll a rendelkezésünkre. Egy kutrigur már az avarok Kárpát-medencei honfoglalása előtt feltünik a forrásokban, mint az avar kagán egyik tanácsadója (MENANDROS PROTÉKTÓR 443, 10 28. vö. SZÁDECZKY-KARDOSS 1998, 21; SZÁDECZKY-KARDOSS 1996, 25). Ezenkívül ez a népesség még egyszer és utoljára jelenik meg az avarok Bizánci Birodalom elleni hadjárataiban, az 568/569-es, Dalmácia elleni támadáskor (MENANDROS PROTÉKTÓR 456, 12-458, 30. vö. SzÁDECZKY-KARdoss 1998, 37; SzÁDECZKY-KARDOSS 1994, 207-208; SZÁDECZKY-KARDOSS 1996, 23). A bulgárok viszont többször megtalálhatók a forrásokban a különböző avar-bizánci összecsapások során: Thessalonike (MIRACULA S. DEMETRII II. 2. 198. vö. SZÁDECZKY-KARDOSS 1998, 159), illetve Konstantinápoly ostromakor (GeÓRgIOS PisidÉS 197-225. vö. SZÁDECZKY-KARDOSS 1998, 190; SZÁDECZKY-KARDOSS 1994, 213; SzÁDECZKY-KARDOSS 1996, 25-26), és az 594-es (THEOPHYLAKTOS SiMOKATTÉS VII. 4, 2-5. vö. Olajos 2012, 238; SzÁDECZKY-KARDOSS 1996, 23), valamint az 598/99-es harcok kapcsán (Michael Syrus X. 24. vö. SzÁDECZKY-KARDOSS 1998, 127). A 6. század végén újabb nomád elemek csatlakozásával számolhatunk. A türk fennhatóság alól 595 körül megszökő nomád népekkel (tarniachok, kotragérok, zabenderek) ${ }^{380}$ bővült az avar kagán hadserege (THEOPHYLAKTOS SiMOKATTÉS VII. 8, 16-17. vö. Olajos 2012, 249; SzÁDECZKY-KARDOSS 1996, 23). A 7. század legelején újból átrendeződtek a hatalmi

\footnotetext{
377 A szabirok történetére lásd CZEGLÉDY 1959, 124-125; CZEGLÉDY 1969; NÉMETH 1991, 149-155; ZIMONYI 1990, 44-45; VRYONIS 1991, 1824; GOLDEN 1992, 104-106.

${ }^{378} \mathrm{Az}$ onogurok történetére lásd MORAVCSIK 1930; GOLDEN 1992, 100-104; VÁSÁRY 1993, 127-131; ZIEMANN 2007, 73-76.

${ }^{379}$ A kutrigurok és utigurok történetére lásd GolDEN 1992, 99-100; ZIEMANN 2007, 95-102; SzEMJONOV 2013, 45-67.

${ }^{380}$ Szádeczky-Kardoss Samu és Olajos Terézia feltételezi, hogy a kotragér népnév kutrigurokat, a zabender pedig esetleg szabirokat takarhatja (SZÁDECZKY-KARDOSS 1990, 22; OlAJOS 2012, 249).
} 
viszonyok a délorosz steppén, a Türk Kaganátus gyengülésével a türkök kiszorultak a térségből, az avarok pedig fokozatosan kiterjesztették hatalmukat a szóban forgó terület egy részére (SzÁDECZKY-KARDOSS 1996, 25; SzÁDECZKY-KARDOSS 1998, 108; FARKAS 2001, 65). Így a Kárpát-medencétől keletre élő nomád népek egy része szintén az avar hadsereg segédnépeit képezhette egészen a 630-as évek elejéig, amikor is Kuvrat önálló birodalmat alapított ezen a területen, ${ }^{381}$ és ezzel megszünt az avar fennhatóság a délorosz steppén (NIKEPHOROS PATRIARKHA 24,9-15. vö. SZÁDECZKY-KARDOSS 1998, 213; BÓNA 1984, 316; SZÁDECZKY-KARDOSS 1994, 214.; SZÁDECZKY-KARDOSS 1996, 26). ${ }^{382}$ A Fredegar-krónika tudósít bennünket arról, hogy 631/32 körül az Avar Kaganátus belsö területén, Pannoniában belviszály alakult ki, és egy avar és egy bulgár jelölt küzdött egymással a kagáni címért (Fredegar IV. 72. vö. SZÁDECZKY-KARDOSS 1998, 212; BÓNA 1984, 316; SzÁDECZKY-KARdoss 1994, 214; SzÁdECZKY-KARdoss 1996, 26). A hatalmi harc vesztesei a bulgárok lettek, akik elmenekültek Pannoniából. Az utolsó információnk a délorosz steppéről a Kárpát-medencébe érkező újabb nomád elemekről a 670-es évekből származik, amikor is Kuvrat - halála után - felbomló birodalma területéröl a negyedik fia és kísérete érkezett az Avar Kaganátus területére, és vált az avar kagán alattvalójává Nikephoros Patriarcha és Theophanes tudósítása alapján (NIKEPHOROS PATRIARKHA 33, 13-34, 19; TheOphanes 357, 8-358, 11. vö. SzÁDECZKY-KARDOSS 1998, 218-219; SZÁDECZKY-KARDOSS1968, 84-87).

Az írott források által említett nomád segédnépek lokalizációja és a régészeti anyagban történő elkülönítése eléggé problematikus. A bulgárok Kárpát-medencei megjelenésének időpontja szintén kérdéses. Az írott források erről nem szolgáltatnak pontos információt számunkra. ${ }^{383}$ A bulgárok avar segédnépként szinte az egész kora avar korban megfigyelhetők az írott forrásokban. Ezzel szemben a kutrigurokat 568/569 után már nem említik az avarok segédnépei között az auktorok, tehát kérdéses a későbbiek folyamán a kutrigur jelenlét az avar hadseregben(BóNA 1981, 104-105). Szintén nehézkes az avar kori régészeti anyagban ezeknek a nomád népeknek az azonosítása. ${ }^{384}$

\footnotetext{
${ }^{381}$ Kuvrat birodalma földrajzi területének lokalizációjához lásd MORAVCSIK 1930, 14; RÓNA-TAS 2001, $67-87$.

${ }^{382}$ Walter Pohl ezzel szemben úgy véli, hogy Kuvrat nem az avar, hanem a türk uralom alól vonta ki magát (PoHL 1988, 270-273).

${ }^{383}$ Ennek ellenére néhány kutató megpróbálta lokalizálni ezeket a nomád népeket. Fehér Géza úgy véli, hogy a bulgár, kutrigur elemek csak az Avar Kaganátus déli és nyugati határterületein találhatók meg 630-ig (FEHÉR 1955, 47). Bóna István szerint ezek a bulgár segédcsapatok a 620-as évekig keletről, a délorosz steppéröl jöttek, és álltak az avar hadvezetés szolgálatába, s csak Samo felkelése (623) után települhettek be kis, jelentéktelen létszámú csapataik a Kárpát-medencébe. Bóna szerint ezeket a betelepülő bulgárokat valahova a (nyugati) határvidékre telepíthették az avarok (BóNA 1981, 106).

${ }^{384}$ Csallány Dezső már az 1950-es években elkülönített egy csoportot a Maros-Körös vidékén, melyet az „,igazi” avarokkal azonosított, és a többi Kárpát-medencei terület (Dunántúl, Duna-Tisza közének északi
} 
Az írott források szerint az avar hadseregben nagy számban voltak jelen nomád segédnépek. Erre utal Menandros Protéktór leírása a 10.000 fös kutrigur (MENANDROS ProtéKTÓR 456, 12-458, 30. vö. SzÁDECZKY-KARDOSS 1998. 37), ${ }^{385}$ Theophylaktos Simokattésé az 1000 fős bulgár (THEOPHYLAKTOS SiMOKATTÉS VII. 4, 1. vö. Olajos 2012, 238), ${ }^{386}$ illetve Fredegaré a 9000 fős bulgár egységről (Fredegar IV. 72. vö. SZÁDECZKYKARDOSS 1998. 212), ${ }^{387}$ valamint a szintén Theophylaktos tudósításában szereplő, a 6. század legvégén keletről beköltöző 10000 harcos (THEOPHYLAKTOS SIMOKATTÉS VII. 8. 16-17. vö. Olajos 2012, 250). ${ }^{388}$ A fent nevezett auktorok számadataival kapcsolatban elsősorban Bóna István fogalmazott meg kritikát (BÓNA 1981, 106). Figyelembe véve a középkori források hadilétszámra vonatkozó adataiknak megbízhatatlanságát nem tekinthetők hitelesnek ezek a létszámadatok. Ugyanakkor a négy forrás számadataiból

része, Dél-Alföld) leletanyagának egy részét a kutriguroknak („,kutrugur-bolgárok /-hunok/”) tulajdonította (CSAllánY 1953, 140; CSAlláNY 1963, 32-38). Ezzel szemben Kovrig Ilona hangsúlyozta, hogy a keleti párhuzamok és az írott források alapján éppen a Maros-Körös-vidéki csoportban gyaníthatjuk a kutrigurokat, és a Csallány véleménye szerinti kutrigur leletanyag az avarság belső-ázsiai rétegével azonosítható. Kovring szerint azonban a kutrigurok csak a 630-as évek elejéig vannak jelen a Kárpát-medencében, mivel kiüzték őket az Avar Kaganátus területéről (KovRIG 1955, 43-44). Ezzel a véleménnyel szemben Bóna István fogalmazott meg kritikát, miszerint Fredegar szóban forgó tudósításában az avar-bulgár hatalmi harc kapcsán egyértelmüen bulgárok találhatók, és nem kutrigurok. Az írott forrásokban szereplő kutrigurok és bulgárok nem feleltethetők meg egymással (BóNA 1981, 106). Legutóbb Bálint Csanád hangsúlyozta, hogy az avar fennhatóság alatt élő kutrigurok régészeti azonosítása problematikus, föként, mert a délorosz steppei jelenlétük sem fogható meg régészetileg (BÁLINT 2010, 160). Újabban Lőrinczy Gábor foglalkozott a KörösTisza-Aranka folyók közötti vidék kora avar kori anyagával, és arra a következtetésre jutott, hogy ezeknek a leleteknek a párhuzama a délorosz steppén található meg. Véleménye szerint ennek a területnek Tisza menti sávját a 6. század utolsó harmadában népesítették be a délorosz steppéröl, s a betelepülő csoport a 7. század elejétől terjeszkedett a Köröstől északra, illetve a Tiszától keletebbre. Lőrinczy Gábor tehát úgy véli, hogy ennek a népességnek a délorosz steppei származása bizonyított, viszont a korábbi elméletekkel szemben nem törekedik arra, hogy mindenáron etnikumhoz kösse a leletanyagot (LÖRINCZY 1998, 351-355; LÖRINCZY 2001, 40-47). A 7. század második felében a Kárpát-medencei avar leletanyagban jelentős változás figyelhető meg, amit a kutatók egy része új népesség bevándorlásával magyaráz. Ezt a bevándorlást az írott forrásokban fellelhető konkrét eseményhez is kötik: Kuvrat birodalmának felbomlása után újabb népelemek (feltehetően onogur-bulgár és egyéb délorosz steppei népesség) érkezhettek a kelet-európai steppéről. László Gyula, majd Bóna István a régészeti megfigyeléseken alapuló érvek mellett az írott források adatait is felhasználta, és próbálta összhangba hozni a régészeti megfigyelésekkel: LÁszLó 1940, 145-158; BóNA 1970, 259-261; BÓNA 1984, 325-327. Bóna István úgy véli, hogy a bulgárok nagyobb tömbben települtek be a Kárpát-medencébe 670 körül (BÓNA 1981, 104-105, 111). Bálint Csanád fogalmazott meg legutóbb tételes kritikát azzal kapcsolatban, hogy a közép avar kor kezdetének régészetianyag-változását egyértelmüen Kuvrat fiának a Kárpát-medencébe bevándorlásával lehet-e magyarázni: BÁLINT 2004a, 35-65. Bálint Csanád hangsúlyozza, hogy a kora avar kor sokszínü, heterogén kultúrának a 7. század második felétől történő egységesülését, homogenizálódását nem újabb betelepülés vagy etnikai változás okozta (BÁLINT 2010, 160-161).

385 Bóna István hangsúlyozza, hogy a „középkori krónikások” egyik leggyengébb oldala a haderők létszámának meghatározása volt (BóNA 1981, 103-104.).

${ }^{386}$ Bóna István szerint ez a számadat a legmegbízhatóbb a bulgár haderő létszámát illetően (BóNA 1981, 106).

${ }^{387}$ Bóna István úgy véli, hogy az ebben a forrásban szereplő, menekülő bulgárok létszáma inkább 1000-re vagy 900-ra tehető (BÓNA 1981, 106).

${ }^{388}$ Ezen számadattal kapcsolatban a szakirodalomban nem található kritika. Szádeczky-Kardoss Samu szerint az első Avar Kaganátus hatalma 600-620-as csúcspontjának elérésében nagy szerepe volt ennek a tízezer steppei harcosnak (SZÁDECZKY-KARDOSS 1998, 108). 
kiderül, hogy a hadi szerveződésük - mint a legtöbb nomád nép esetében is - tízes rendszeren alapult. Az auktorok híradásai arra utalnak, hogy ezek a nomád népek nemcsak az avar hadseregen belül, a többi alávetett néppel együtt vettek részt a hadjáratokban, hanem önálló akciókat is végrehajtottak. Az imént említett két forrás, Menandros Protéktór és Theophylaktos Simokattés leírása is arra utal, hogy bár a kagán utasítására, de önálló akciót indítottak. Ennek oka a kagán szemszögéböl nemcsak a feltétlen bizalom lehetett, vagyis, hogy biztosra vette nomád alávetettjei hüségét, hanem az is, amiről Menandros Protéktór tudósít bennünket, hogy a kagán az 568/569-es, Dalmácia elleni megtorló hadjáratra (amiért a császár nem küldött neki ajándékokat) csak azért küldte kizárólag a kutrigurokat, mert biztosra vette a vereségüket és a pusztulásukat (MENANDROS PROTÉKTÓR 456, 12-458, 30. vö. SzÁDECZKY-KARDOSS 1998, 37). Az írott kútfőkből nehezen következtethetünk e népek tényleges harcmodorára és fegyverzetére az Avar Kaganátuson belül. Az avarok délorosz steppei támadását megelőzően a szóban forgó nomád népek kapcsán többnyire csak a támadásaikat emelik ki az auktorok, harcmodorukra, fegyverzetükre nem térnek ki. Agathias a kutrigurok Bizánci Birodalom elleni 559-es hadjárata esetében utal arra, hogy váratlan, rajtaütésszerü támadást intéztek a rómaiak ellen, és hadjáratuk során főként a kevésbé erődített településeket igyekeztek megtámadni (Agathias V. 11, 6-7. vö. Frendo 1975, 144-145). A már avar fennhatóság alatt álló nomád népek közül a bulgárokra vonatkozóan Theophylaktos Simokattés munkájából kiderül, hogy az 594-ben a bizánciak által megtámadott bulgár sereg fegyelmezetten, egységes, zárt hadrendben vette fel a harcot a bizánci hadsereggel, és a végén le is győzte azt. A győzelem után a forrásrészlet utolsó szakasza szerint a bolgárok lassan, térdüket emelve, apró lépésekkel húzódtak vissza (THEOPHYLAKTOS SIMOKATTÉS VII. 4, 1-5. vö. Olajos 2012, 238). Ebből az utolsó elembö1 elsősorban a nehézfegyverzetü lovasságra következtethetnénk, azonban ezt az utolsó részletet Theophylaktos Homérosz Iliász eposzából kölcsönözte (HomÉROS, Ilias XI. 547. vö. Devecseri 1967, 197; OLAJOS 2012, 238). Tehát a forrásból csak azt állapíthatjuk meg, hogy egységes, zárt hadrendben támadtak a bulgárok, az viszont nem egyértelmű, hogy nehézfegyverzetủ lovasság vagy nehézfegyverzetű gyalogság győzte-e le a bizánciakat. ${ }^{389}$

\footnotetext{
${ }^{389}$ Az írott forrásokban fellelhető nomád segédnépek anyagi kultúrájának a kora avar kori régészeti anyagban történő azonosítási kísérletei alapján a következő jellegzetes fegyverek köthetők hozzájuk: egy- és kétélü kardok, szablyák. A délorosz steppéről származó alávetett segédnépeknek tulajdonított leletanyag (a MarosTisza-Aranka-vidéki csoport) fegyvermellékletei közül kiemelendőek az egy- és kétélü kardok, viszonylagos nagy számuk és egyenletes elterjedésük miatt (LÖRINCZY 1998, 354; LÖRINCZY 2001, 44). A 7. század második felétöl bekövetkező leletanyag-változás a fegyverzet terén is megfigyelhetö. A vágófegyverek közül ebben az időszakban jelennek meg a szablyák a Kárpát-medencében. Természetesen ahogy ezeknek a
} 
A nomád segédnépek esetében az írott források és a régészeti anyag alapján könnyüfegyverzetü és nehézfegyverzetü lovasságot, valamint esetleg nehézfegyverzetü gyalogságot feltételezhetünk az avar korban. Thessalonike ostromának Johannes Stauracius-féle leírásából pedig arra következtethetünk, hogy a bizánci városok ostromában is aktívan részt vehettek a nomád segédnépek.

\section{2. 4. 2. Szláv segédnépek}

Az alávetett népek közül a szlávokat gyakran említik az írott kútfők. Az avarok már a délorosz steppei vándorlásuk során meghódoltattak egy szláv nyelvü népességet, az antokat (MenANDros ProtéKTór 443, 10-28. vö. SzÁdeCZKY-KARdoss 1998, 21; POHL 1988, 40.; SZÁDECZKY-KARDOSS 1994, 207; SZÁDECZKY-KARDOSS 1996, 21). Menandros Protéktór munkájából azonban úgy tünik, hogy ez a nép elsősorban a rabszolgaszerzés céljából érdekelte az avarokat, és kevésbé lehettek fontosak segédnép funkcióban a hadseregükben. Ezenkívül még néhány adat található a forrásokban a langobard-avar kapcsolatok $^{390}$ és a bajor-avar összecsapások (PAULus DiACONUS IV. 10. vö. Galamb 2012, 129; SZÁDECZKY-KARDOSS 1994, 212; SZÁDECZKY-KARDOSS 1996, 23) esetében a szlávokról, valamint az Avar Kaganátus gyengülésekor a birodalomtól elszakadó szláv népekről esik szó a forrásokban: Samo vendjei (Fredegar V. 48. vö. SZÁDECZKY-KARDOSS 1998, 173; BÓNA 1984, 316; POHL 1988, 256-261; SzÁDECZKY-KARDOSS 1996, 25) és a délszlávok (KÓNSTANTINOS PORPHYROGENNÉTOS, De administrando imperio 30, 60-73, 32, 7-13, 15-9, 146-148. vö. SZÁDECZKY-KARDOSS 1998, 214; BÓNA 1984, 316; SZÁDECZKY-KARDOSS 1996, 26). A legtöbbször azonban a bizánci-avar összecsapások kapcsán említik őket az auktorok: ${ }^{391}$ az 584-es (Michael Syrus X. 21. vö. SzÁDECZKYKARDOSS 1998, 61; SzÁDECZKY-KARdOSS 1996, 22), az 585-ös (Theophylaktos SiMOKATTÉS I. 6, 6-7, 6. vö. SZÁDECZKY-KARDOSS 1998, 64; SZÁDECZKY-KARDOSS 1996,

népeknek a régészeti anyagban történő azonosítása, úgy a régészeti anyagban megfigyelhető jellegzetes fegyverek nomád népekhez történő kötése is nagyon problematikus.

${ }^{390} 602$ körül a langobardokkal szövetségben támadták Isztriát az avarok és a szlávok (PAULUS DIACONUS IV. 24. vö. Galamb 2012, 134; SZÁDECZKY-KARDOSS 1996, 24). 603-ban az avar kagán szláv segédcsapatokat küldött a langobard királyhoz, Bizánc elleni hadmüveleteihez (PAULUS DiACONUS IV. 28. vö. Galamb 2012, 135; SZÁDECZKY-KARDOSS 1990, 212; SZÁDECZKY-KARDOSS 1996, 24).

${ }^{391}$ A közös szláv-avar hadjáratok kapcsán a hadsereg nagy részét a szláv segédnép alkothatta, az avarok pedig a hadjáratokat szervezhették, vezethették. Ez a jelenség különösen a Peloponnésos-félszigetre történő támadás és letelepedés esetében figyelhető meg a forrásokban, amelyek a szlávokat is avar néven nevezik. A térségben történő letelepedést követően a kisszámú avar vezetöréteg asszimilálódhatott a szláv segédnépéhez. Az Avar Kaganátus gyengülésével Bizánc újból hatalma alá hajtotta ezt a területet, és az ott lévő népességet már ismét szlávoknak nevezték az auktorok (OLAJOS 1987, 82-83). 
22), az 588-as (Chronicon Monembasiae 86-97, 116-121, 13-140. vö. SzÁDECZKYKARdoss 1998, 72-73; SzÁdECZKY-Kardoss 1996, 22), az 592-es (ThEOPHYLAKTOS SIMOKATTÉS VI. 3, 9-4, 5. vö. Olajos 2012, 218-219) Bizánc elleni támadásoknál. 593-ban viszont Bizánc támadta meg az avar hatalmi szférához tartozó al-dunai szlávokat (THEOPHYLAKtos SimOKATtéS VI. 7, 1. vö. Olajos 2012, 224; BóNA 1984, 314)' 594-ben pedig az Al-Duna vidékén portyázó szláv csapatot semmisítették meg a bizánci egységek (TheOPHYLAKtos SimoKATtÉS VII. 2, 2-9. vö. Olajos 2012, 235-236). Thessalonike első avar ostromakor is számolhatunk nagyszámú szláv segédcsapatokkal (MIRACULA S. DEMETRII I. 13. 117. vö. SZÁDECZKY-KARdoss 1998, 113-114; SZÁdECZKY-KARDOSS 1996, 23). Priskos 599-es avarok elleni hadjáratakor Theophylaktos Simokattés szerint a Tisza (vagy esetleg a Temes) környékén történt avar-bizánci összecsapásban az avarok oldalán nagyszámú szláv csapat is részt vett, melyből 8000 szláv harcos esett fogságba (TheOPhylaktos Simokattés VIII. 3, 15. vö. Olajos 2012, 272; SzÁdeCZKY-Kardoss 1996, 24). Thessalonike városának 609-es ostromakor csak szláv csapatokat említ a forrás (Miracula S. DemetriI I. 12. 107-108. vö. SzÁdECZKY-Kardoss 1998, 147). Az Isztria elleni 611-612 körüli támadás kapcsán szintén ezek a népek szerepelnek Paulus Diaconus munkájában (PAUlus DiACONUS IV. 40. vö. Galamb 2012, 143). 614-ben az avarok szláv segédnépeikkel együtt foglalták el Salonát, és a szlávok elárasztották egész Hellast (KóNSTANTINOS PORPHYROGENNÉTOS, De administrando imperio 29, 1-53; 30, 6-61. vö. Moravcsik 2003, 123-125; SZÁDECZKY-KARDOSS 1996, 24). Thessalonike 615-ös sikertelen szláv ostroma után 618-ban az avar hadsereg segítségével próbálták újból bevenni a várost, ami ismét nem járt sikerrel (MIRACULA S. DEMETRII II. 1. 179, 182-192; II. 2. 198-214. vö. SZÁDECZKY-KARDOSS 1998, 157-158, 159-160; SZÁDECZKY-KARDOSS 1996, 24). Az avarok Bizánci Birodalom elleni utolsó nagy vállalkozásában, Konstantinápoly ostrománál szintén említik a források a szlávokat (GEÓRGIOS PISIDÉS 197-225; Chronicon Paschale 719. 5-16; Theodóros Synkellos XXII. 307, 8-17, XXIII. 307, 37-40; XXIV. 308, 1-21. vö. SzÁDECZKY-KARDOSS 1998, 178, 184, 187; BÓNA 1984, 315; SZÁDECZKY-KARDOSS 1996, 26)

A szlávokhoz köthető régészeti anyag elkülönítése, meghatározása szintén több problémát vet fel. Az azonban megállapítható a Kárpát-medence 6. századi régészeti anyagának vizsgálata alapján, hogy a mai Magyarország területén 568 előtt nem voltak szlávok. Az írott forrásokban egyértelműen megfigyelhető szlávok a régészeti anyagban csak a 7. század első felétől tünnek fel a Dunántúl területén. A szlávok régészeti hagyatékához elsősorban a hamvasztásos sírok köthetők, melyek a 7. század elejétől 
figyelhetők meg a Dunántúl területén (Cs. Sós 1968, 221-225; BÓNA 1971, 304; SzŐKE 1998, 260). ${ }^{392}$

A szláv segédcsapatok létszámára csak néhány forrás utal. 594-ben a bizánci hadsereg egy 600 fös portyázó szláv egységet semmisített meg (THEOPHYLAKTOS SiMOKATTÉS VII. 2, 1-3. vö. Olajos 2012, 235). A Miracula Sancti Demetriiből értesülünk egy 5000 főből álló szláv sereg 609-es, Thessalonike elleni önálló ostromáról (MIRACULA S. DeMETRII I. 12. 107. vö. SzÁdECZKY-KARDOSS 1998, 147). Theophylaktos Simokattés szerint Priskos 599-es hadjáratakor 8000 szlávot ejtett foglyul (amellett, hogy nagy létszámú szláv csapatot semmisített meg) (TheOPHYLAKTOS SimOKATTÉS VIII. 3, 1-15. vö. Olajos 2012, 272). ${ }^{393}$ Azon kívül a szemponton kívül, hogy a középkori források létszámadatai a legtöbb esetben megbízhatatlanok, megjegyzendő, hogy győztes csata esetében igyekeztek felnagyítani az ellenség veszteségeit, hogy ezzel is kiemeljék a győzelmük jelentőségét (OLAJOS 2012, 271). A szláv segédcsapatok többféle módon viszonyultak az avar sereghez. ${ }^{394}$ A forrásokból úgy tünik néhány esetben, hogy a szlávok önálló akciójáról lehet szó. A Szent Demeter csodáiból nem derül ki egyértelmúen, hogy az avar kagán megbízását teljesítették volna a Thessalonikét ostromló szlávok vagy önálló akcióról volt szó (MiRACUla S. DEMETRII I. (12) 107. vö. SzÁdECZKY-Kardoss 1998, 147). Vannak adataink arra vonatkozólag is, hogy szintén önálló csapattestként önálló hadi tevékenységet folytatnak, de egyértelmủen a kagán akaratát teljesítik. Erre jó példát találunk Paulus Diaconus munkájában, amikor arról tudósít, hogy 603-ban az avar kagán

${ }^{392}$ Cs. Sós Ágnes volt az, aki először az oroszlányi temető három sírjának anyagából kiindulva - keleti párhuzamok alapján - próbálta azonosítani a keleti szláv népességet. Véleménye szerint ez a szláv csoport az avarokkal közösen a 6. század második felében települt be a Dnyeper környékéröl. Hasonló keleti párhuzamra utaló leletet gyüjtött még össze más dunántúli lelőhelyekröl is (Pécs-Köztemető, Cserkút, Sióagárd-Mocfacsárda) (Cs. Sós 1958, 116-124). Bóna István ellenben úgy gondolja, hogy Cs. Sós Ágnes túlságosan nagy szerepet tulajdonít a keleti szláv etnikumnak, és Pannoniában Oroszlány és Pécs-Köztemető esetében tartotta megalapozottnak a keleti szláv jelenlétet (BÓNA 1971, 306). A 6. század második felében vázas temetkezésekben megfigyelhetök olyan viseleti elemek, mellékletek (például a trapéz alakú hajdíszek, ón- vagy ólomcsövecskék), melyek a szláv kulturális miliőhöz köthetők, ez azonban nem jelenti azt, hogy ténylegesen is a szláv etnikumhoz tartoztak volna. Szőke Béla Miklós szerint a kora középkori szlávok legmarkánsabb etnikumjelző sajátossága a hamvasztásos temetkezés a Kárpát-medencében, ez azonban csak a 7. század első felétől figyelhető meg az egykori Avar Kaganátus területének egy részén (SzÖKE 2000, 477479).

${ }^{393}$ A bizánciak győzelmének leírásakor a foglyul ejtettek létszáma szövegromlással torzítottan maradt fenn (SZÁDECZKY-KARDOSS 1998, 134). Ugyanakkor Walter Pohl úgy véli, hogy ezek a számadatok jól mutatják az avarok és a szláv segédcsapataik létszámának aránybeli különbségét: a szláv segédcsapatok jóval több harcosból álltak, mint az avar egységek (POHL 2000, 348). Összehasonlításképpen az avar foglyok létszáma 3000 fö volt Theophylaktos szerint (OLAJOS 2012, 272).

${ }^{394}$ Az avar-szláv viszony kapcsán Walter Pohl megjegyzi, hogy a szláv társadalomban is voltak a katonai elit kialakulását jelző tendenciák, melyek igen sokszor az avarokkal szembeni összeütközésekhez vezettek. Gyakran azonban megfeleltek az avar kagán stratégiai elképzeléseinek. A szlávokat rendszeresen bevetették segédcsapatként. Az avarok, amíg ez egyezett az érdekeikkel, eltürték vagy akár támogatták saját önálló hadmüveleteiket (POHL 2000, 350-351). 
szláv segédcsapatokat küldött a langobard királyhoz Bizánc elleni hadmüveleteihez (Paulus Diaconus IV. 28. vö. Galamb 2012, 135). A Bizánc elleni önálló szláv akció esetében pedig az 585-ös és az 594-es szláv támadást lehet még megemlíteni (Theophylaktos Simokattés I. 6, 6-7, 6; VII. 2, 1-9. vö. Olajos 2012, 82, 236-237). Ezek mellett a szláv csapatok a legtöbb esetben az avarokkal, az avar hadseregen belül vettek részt különféle hadi vállalkozásokban. 602-ben a langobardok az avarokkal és a szlávokkal Isztriát támadták meg és dúlták fel (PAULUS DiACONUS IV. 24. vö. Galamb 2012, 134). Erre a jelenségre a Bizánci Birodalom elleni avar támadások során több példát találunk: az 584-es és az 592-es Bizánc elleni hadjáratok, valamint az 599-es bizánci támadáskor a források szerint az avar hadsereg rendelkezett szláv csapategységekkel is (Michael Syrus X. 21. vö. SzÁdECZKY-KARdOSS 1998, 61; THEOPHYLAKTOS SimOKATTÉS VI. 3, 9-5, 16; VIII. 2, 10-15. vö. Olajos 2012, 218-222). Ezenkívül a Húsvéti krónika és a Szent Demeter csodáinak adatai is erre utalnak Konstantinápoly és Thessalonike ostroma kapcsán (Geórgios Pisidés 197-225; Chronicon PAschale 719, 5-16; TheOdóros SYNKELlOS XXII. 307, 8-17, XXIII. 307, 37-40; XXIV. 308, 1-21; Miracula S. DEMETRII I. (13) 117; (II. 1.) 179, 182-192; (II. 2.) 198- 214. vö. SZÁDECZKY-KARDOSS 1998, 178, 184, 187, 113-114, 157). A szláv népek harcmodorának, fegyverzetének általános jellemzése a vizsgált korszakra vonatkozóan Maurikios munkájában lelhető fel, melyből kitűnik, hogy kerülik a nyílt összecsapást, és inkább hirtelen, meglepetésszerü támadásokat alkalmaznak nappal és éjszaka az ellenséggel szemben. Erdőkben és szük területeken jobban tudnak harcolni, és folyón való átkelésben is nagy tapasztalatuk van. A fegyverzet kapcsán megemlíti a bizánci szerző, hogy minden szláv férfi két dobódárdával ${ }^{395}$ rendelkezik, és csak néhányan használnak nehéz pajzsokat. Emellett szintén a fegyverzetükhöz tartozott a fából készült ij ${ }^{396}$ és a mérgezett nyíl (MAURIKIOS XI. 4). Fügedi Erik szerint az avar fennhatóság alá kerülő szlávok hódítóik hatására felhagytak a Maurikios által leírt taktikájukkal, és zárt hadrendben, fegyelmezetten, könnyü- és nehézfegyverzetü gyalogosként vettek részt nyílt ütközetekben, illetve a városok ostromában. Tehát az avar hadseregben azokat a szerepeket töltötték be, amelyek az avarságnál a szerző szerint „hiányoztak” (FüGEDI 1946-1948, 320-321). Azonban ha az

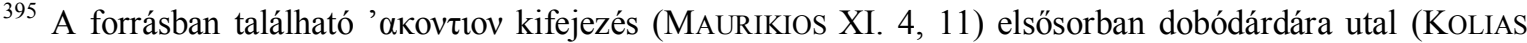
1988, 187).

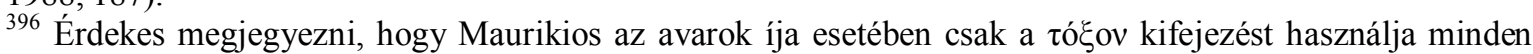
jellemzés nélkül (MAURIKIOS XI. 2, 6). A szlávok kapcsán viszont hozzáteszi, hogy fából készült (MAURIKIOS XI. 4, 11). Mivel a tółov kifejezés általában vonatkozott az íjra, de ebben az időszakban elsősorban az összetett reflexíjat jelentette (KoLIAS 1988, 214-215), elképzelhetö, hogy ezzel akart különbséget tenni a szerző az avarok által használt összetett reflexíj és a csak fából készült egyszerü botíj között.
} 
avar kori szlávokra vonatkozó forrásokat megvizsgáljuk, akkor azt látjuk, hogy harcmodoruk sokkal változatosabb, összetettebb. Maurikioshoz hasonlóan Theophylaktos Simokattés is megemlékezik a dobódárdájukról: 594-ben az Al-Duna vidékén portyázó szlávok a szekérsáncuk mögül hajították a dobódárdájukat az ellenség felé (TheOphylaktos SiMOKATtÉS VII. 2, 1-5. vö. Olajos 2012, 235). ${ }^{397}$ Szintén Theophylaktos Simokattés munkája utal arra, Maurikios leírásához hasonlóan, hogy kerülték a nyílt ütközetet, az al-dunai szlávok például 593-ban a bizánciak támadása elől az erdőbe és a mocsarakba menekültek, ahová a bizánci sereg nem tudta követni öket (TheOPhylaktos SimOKATTÉS VI. 8, 10-12. vö. Olajos 2012, 227). 594-ben pedig az egyébként lovassággal (is) rendelkező szlávok, miután elfogott bizánci felderítőktől értesültek a bizánciak tervezett vonulási irányáról, egy folyó átkelőhelyénél az erdőbe elrejtőzve várták be bizánci sereget, és rajtaütésszerü támadást intéztek ellene. Az összecsapásból, a kezdeti sikerek ellenére, a bizánciak kerültek ki győztesen (TheOphylaktos SimOKATtÉS VII. 4, 10-5, 4. vö. Olajos 2012, 239). A forrásokban megfigyelhető, hogy az avarok a szláv segédnépeik - Maurikios által említett - folyón történő átkelésben leírt jártasságukat is felhasználták a hadjárataik során. Theophylaktos híradásából kitủnik, hogy 592 táján az avar kagán megparancsolta a szlávoknak csónakok készítését az avar hadsereg Dunán történő átszállítása céljából (THEOPHYLAKTOS SIMOKATTÉS VI. 3, 9. vö. Olajos 2012, 218). Thessalonike ostromakor a tenger felől fatörzsből készült csónakjaikon próbálták bevenni a várost (MIRACULA. S. DEMETRII II. 179-189. vö. SzÁDECZKY-KARDOSS 1998, 157). Ezenkívül még Konstantinápoly 626-os ostromakor a szláv csónakosoknak kellett volna a perzsa sereget átszállítaniuk a Bosporus európai partjára. A történet rávilágít arra, hogy míg folyón való átkelésre jól lehetett használni ezeket a vízi jármúveket, addig hadi célokra teljesen alkalmatlanok voltak. A bizánci flotta teljesen megsemmisítette őket (CHRONICON PASCHALE 722, 14-725, 15. vö. SzÁDECZKY-KARDOSS 1998, 185). Walter Pohl szerint az Avar Kaganátus gyengülése idején az avar hadseregben lévő szláv segédcsapatoknál számolhatunk lovassággal is (PoHL 2000, 349), ${ }^{398}$ mely már korábban is kimutatható az írott forrásokban. Az 594-es bizánci-szláv összecsapás kapcsán említi a szerző, hogy a lovaikról leszálló, hűsölni készülő szlávok fogtak el néhány bizánci felderítőt (THEOPHYLAKTOS SIMOKATTÉS VII. 4,

\footnotetext{
${ }^{397}$ Ezt a fegyvert - akárcsak Maurikios - a dobódárda jelentéssel bíró 'akovtıov-al jelöli az auktor (THEOPHYLAKTOS SimOKATTÉS VII. 2, 1-5).

${ }^{398}$ Úgy véli, hogy elsősorban az Avar Kaganátus gyengülésekor, a birodalom perifériáján lévő szláv népcsoportok esetében feltételezhetö, akik új regionális közösségeket alakítottak, és átvettek bizonyos avar tradíciókat is (POHL 2000, 349).
} 
1. vö. SZÁDECZKY-KARDOSS 1998, 104). Emellett a Fügedi által hangsúlyozott taktika is markánsan kirajzolódik a forrásokban. A Húsvéti krónika egyértelmüen utal Konstantinápoly ostromakor az avar hadsereg szláv könnyüfegyverzetű gyalogságára. A forrásban megfigyelhető, hogy közvetlenül a szláv könnyüfegyverzetü gyalogság mellett a nehézfegyverzetü gyalogság is szerepel, ez utóbbit azonban nem köti konkrét néphez. Lehetnek ezek is szlávok, de más népek sem zárhatók ki ebből a harcmodorból. ${ }^{399}$ A Húsvéti krónika ezeknek a csapategységeknek a felállásáról is megemlékezik: a seregrész mélységi felállásában az első vonalban voltak a szláv könnyüfegyverzetü gyalogosok, a második vonalban pedig a nehézfegyverzetü gyalogság helyezkedett el (CHRONIKON PASCHALE 719, 5-16. vö. SZÁDECZKY-KARDOSS 1998, 184). Fredegar krónikájában a vendeknek az avar hadseregen belül betöltött szerepére is találunk utalást, miszerint ez a népesség képezte az elővédet (Fredegar V. 48. vö. Szádeczky-Kardoss 1998, 173). Ezenkívül a 615-ös önálló szláv ostrom leírásából kiderül, hogy a támadók ostromgépeket is használtak.

\section{2. 4. 3. Germán segédnépek}

A letelepült népek közül szintén jelentős szerepet tölthettek be az avar hadseregen belül a gepidák, bár jóval kevesebb forrás emlékezik meg Kárpát-medencei jelenlétükről, mint az előbb említett másik két csoportról. Paulus Diaconus munkájából egyértelműen kitűnik, hogy a Gepida Királyság 567-es bukása után a gepidák egy része avar fennhatóság alá került (Paulus Diaconus I. 27. vö. Galamb 2012, 81-82). Erre utal egy, Menandros Protéktór munkájában található részlet is, mely szerint a Bizáncban lévő avar követek 569/570 táján azt hangsúlyozták, hogy a gepidák az avarok fennhatósága alá tartoznak (MENANDRos ProtéKtóR 195, 26-198, 10. vö. SzÁdECZKY-KARDOSs 1998, 38). Az írott források föként a Bizánci Birodalomba menekülő gepidákról emlékeznek meg, valamint néhány esetben feltűnnek az avarok Bizánc elleni hadjáratában is. A fent említett 569/570es követjárás során követelték az avarok a gepida Usdibados kiadatását a bizánciaktól (MEnANdros ProtéktóR 195, 26-198, 10. vö. SzÁdECZKY-KARdoss 1998, 38). Theophylaktos Simokattés híradásából értesülünk arról, hogy 586 vagy 587 körül az alávetett gepidák közül hét a menekülö Bookolabrassal tartott a Bizánci Birodalom

\footnotetext{
${ }^{399}$ Fügedi Erik szerint ez az egység elsősorban szlávokból állhatott (FÜGEDI 1946-1948, 321), Pohl a szlávok mellett bulgár elemeket is feltételez a nehézfegyverzetủ gyalogságban (POHL 2000, 348). Emellett a nehézfegyverzetủ gyalogság esetében nem zárhatók ki a gepidák sem (lásd lentebb).
} 
területére (TheOPHYLAKTOS SimOKATtÉS I. 8, 1-11. vö. Olajos 2012, 83-84; POHL 1988, 229). Ugyancsak ő tudósít bennünket arról, hogy 593-ban a bizánciakhoz szökött egy avar uralom alá tartozó gepida férfi, akinek az aktív segítségével Priskos győzelmet aratott az avar fennhatóság alatt álló szlávokon (THEOPHYLAKTOS SimOKATtÉS VI. 8, 13-9. vö. Olajos 2012, 227). Valószínűleg szintén az avar fennhatóság alól menekült az a gepida férfi, aki egy vadászat során arany övszerelékeiért és lovának arany lószerszámvereteiért megölt egy császári testőrt (THEOPHYLAKTOS SIMOKATTÉS VI. 2, 3-9; VI. 10, 4.-18. vö. Olajos 2012, 215). Theophylaktos Priskos 599-es avarok elleni sikeres hadjáratának leírásakor megemlékezik arról, hogy a bizánci felderítők három gepida helységet fedeztek fel, és a helyi ünnepüket ülő, mit sem sejtő gepidák felett megsemmisítő győzelmet arattak. Az auktor erősen túlzó számadatot közöl arról, hogy hány gepidát öltek meg a bizánciak: szerinte 30 ezer „barbárt”, sokukat pedig fogságba ejtettek (THEOPHYLAKTOS SIMOKATTÉS VIII. 3, 1-15. vö. Olajos 2012, 271-272; POHL 1988, 229-230). A szerző a hadjárat során felsorolja az avar hadsereg a hadjárat során fogságba esett egységeinek létszámát, viszont nem említi meg név szerint a gepidákat az avar hadseregben. ${ }^{400}$ A Theophylaktos munkáját felhasználó, a 8. század második felében, a 9. század elején élő Theophanes viszont megemlékezik a gepidákról is az ezen esemény kapcsán. ${ }^{401}$ Emellett szintén Theophanes tudósít arról, hogy Konstantinápoly 626-os ostromában gepidák is részt vettek (Theophanes 6117. vö. SzÁdeCZKY-Kardoss 1998, 180; PoHL 1988, 230). Az írott források tehát egyértelműen utalnak gepida jelenlétre az Avar Kaganátuson belül, viszont csak két esetben tünnek fel az avarok hadi vállalkozásaiban. Valószínüsíthető, hogy több alkalommal részt vettek az avar hadsereg hadjárataiban, csak az írott források nem említették őket. ${ }^{402}$

A régészeti anyagban is fellelhetők a gepidákhoz köthető emlékek az avarok Kárpát-medencébe történő beköltözése után is. Az egykori Gepidia területei közül Erdélyben a kora avar kori Mezőbánd-Marosveresmart csoporthoz tartozó temetők sírjai köthetők a gepida továbbéléshez (BÓNA 1986, 162-136; NAGY et al 2000, 172-173;

\footnotetext{
${ }^{400}$ Theophylaktos az avarokon kívül szlávokat és „egyéb barbárokat” említ az avar hadseregen belül. A forrás szerint 3000 avar, 8000 szláv és 4000 és 2200 egyéb barbár került bizánci fogságba (THEOPHYLAKTos SIMOKATTÉs VIII. 3, 1-15. vö. Olajos 2012, 271-272).

${ }^{401}$ A kései szerző 3000 avar, 800 szláv, 3200 gepida és 2000 barbár hadifoglyot említ. Szádeczky-Kardoss Samu és Olajos Terézia mutatott rá arra, hogy a Theophylaktos kézirati hagyományában található hadifogolylétszám-adatokat tartalmazó rész szövegromlással torzítottan maradt fenn, csakúgy, mint Theophanes munkájának erre vonatkozó részlete (SZÁDECZKY-KARDOSS 1998, 134; OlAJOS 2012, 272).

${ }^{402}$ Ezenkívül a gepidák említése még két forrásban lelhető fel: a 8. század végi Theodulfus orleans-i püspök egyik költeményében és a Conversio Bagoariorum et Carantanorumban is. A két forrásrészletre vonatkozó kritikai észrevételeket lásd KISS P. 2010b, 125-129.
} 
DoBos 2013, 98-101). ${ }^{403}$ A Tisza-vidéken pedig, a korábban általánosan elfogadott véleménnyel ellentétben, úgy tűnik, hogy a gepida temetők (egy részének a) ${ }^{404}$ használata nem szünt meg az avar honfoglalással. ${ }^{405}$

A gepida segédcsapat létszámára csak Theophanes munkája utal, melyből semmiféle következtetést nem tudunk levonni erre vonatkozóan, leírása szerint Priskos 599-es sikeres, avarok elleni hadjárata során 3200 gepida került bizánci fogságba (THEOPHANES 6093. vö. SzÁDECZKY-KARDOSS 1998, 134-135). ${ }^{406}$ A korabeli szerzők nem emlékeznek meg a gepidák harcmodoráról, fegyverzetéröl, avar hadseregben betöltött szerepéről. Azonban a korábbi időszakra vonatkozó forrásokból és a régészeti anyagból kitünik, hogy a gepidák harcmodorában elsősorban a közelharc, ezen belül is a lándzsát vagy hosszú kétélü kardot alkalmazó gyalogság volt a meghatározó, emellett azonban a lovasságukkal is kell számolnunk (SEVIN 1955, 122-125; BóNA et al. 1993, 61-63). Legutóbb Kiss P. Attila a Tisza-vidéki gepida fegyveres sírok vizsgálata során kiemelte, hogy ezekben a temetkezésekben a közelharc fegyverei dominálnak (spatha, lándzsa, sax, pajzs). Ezzel párhuzamosan a szerző felhívja a figyelmet, hogy a sírokban található fegyvermellékletek nem minden esetben tükrözhetik a valós életben használt fegyvereket (KISS P. 2012, 154). Valószínűsíthető, hogy a kora avar korban elsősorban a nehézfegyverzetü gyalogság szerepét tölthették be a gepidák az avar hadseregben. Feltételezhető, hogy a Húsvéti krónika által említett nehézfegyverzetű gyalogság alatt őket is kell érteni (CHRONICON PASCHALE 719, 5-16. vö. SzÁDECZKY-KARDOSS 1998, 184).

A gepidák segédnépi funkciója két nomád birodalom keretein belül is

\footnotetext{
${ }^{403}$ Például Marosnagylak, Marosveresmart, Mezőbánd, Baráthely (BóNA 1986, 162-136; NAGY et al 2000, 172-173; DoBOs 2013, 1. térkép).

${ }^{404}$ Például Tiszagyenda-Búszerző II. (Kocsis 2010, 17), Hódmezővásárhely-Kishomok 1., 7. sír (BÓNANAGY 2000, 149; NAGY 2004, 174).

${ }^{405}$ Felmerült a kutatásban annak a lehetősége is, hogy az avar korban a gepidákat áttelepítették korábbi területükről a Dunántúlra, Kiss Attila föként régészeti adatok alapján, de az írott források adatait is bevonva jutott erre a következtetésre (KISS 1992, 50; KISS 1996, 304-305; KIss 2001, 103-405). Kiss Attila hangsúlyozta, hogy néhány erdélyi kivételtől eltekintve nem az egykori települési terület helyén kell keresni az avar kori gepidákat. Számos germán jellegű lelőhelyet felsorol Pannonia területéről, amelyek régészeti anyaga véleménye szerint kapcsolatokat mutat az 567 előtti Tisza- és Maros-parti gepida lelőhelyekkel. Például Kölked-Feketekapu A., Kölked-Feketekapu B., Bóly-Sziebertpuszta B, Nagyharsány-Szakás dülö, Pécs-Köztemető, Környe, Budakalász-Dunapart, Csákberény-Orondpuszta, Várpalota-Gimnázium, Zamárdi-Rétiföldek, Andocs-Németsürü, Szekszárd-Bogyiszló (KIss 1992, 50; Kiss 1996, 304-305; Kiss 2001, 103-405). Ezzel az elmélettel szemben azonban több ellenvélemény is született, amelyek több ponton cáfolták Kiss Attila teóriáját (BÓNA et al. 1993, 75; BÁLINT 1995, 310-312; VIDA 2008, 29-31; KISS P. 2010b).

406 A gepida népesség létszámára vonatkozóan csak egy erősen túlzó számadat áll rendelkezésünkre. Theophylaktos Simokattés a bizánciaknak az avarok elleni 599-es hadjárata kapcsán említi, hogy 30000 gepidát öltek meg (TheOPHYLAKTOS SimOKATTÉs VIII. 3, 1-15. vö. Olajos 2012, 271-272). SzádeczkyKardoss ezt a számadatot nem tartja hitelesnek, szerinte inkább néhány ezer före kell gondolnunk (SZÁDECZKY-KARDOSS 1998, 134). Hasonló véleményen van Walter Pohl is (POHL 1988, 229-230).
} 
megfigyelhető: a hunok és az avarok esetében. Walter Pohl mutatott rá először egy lényeges különbségre ezzel kapcsolatban. Míg a Hun Birodalomban az alávetett segédnépek - így a gepidák is - vezetői saját népükből kerültek ki, és a hun uralkodó közvetlen környezetéhez tartoztak, addig az avaroknál az írott források tanúsága szerint alávetettjeik „,névtelenek”, vagyis a segédnépek vezetői közül egy sem töltött be fontos szerepet a kagán szükebb környezetében (PoHL 1988, 225-227). ${ }^{407}$

Kevés írott forrásos adat áll rendelkezésünkre az avar fennhatóság alatt élő langobardokra. A források ugyan nem emlékeznek meg arról, hogy az 568-ban történő kivonulásukkor maradt volna langobard népesség a Kárpát-medencében, de ennek ellenére egyáltalán nem zárható ki ez a lehetőség sem (PoHL 1988, 229). Emellett néhány adatunk van arra is, hogy a későbbiekben is települtek be langobardok a Kárpát-medencébe. ${ }^{408}$ Emellett a források megemlékeznek arról is, hogy az itáliai langobardok és az avarok időnként közös hadi vállalkozásokat folytattak, vagy „segítették” egymást a hadjárataik során. Erre jó példát találunk a 6. század végén, amikor Agilulf langobard király hajóácsokat küldött az avar kagánnak, és ezeknek a segítségével a kagán egy Trákiában található szigetet foglalt el (PAULuS DiACONUS IV. 20. vö. Galamb 2012, 132). ${ }^{409}$ Az avar kori langobard jelenléthez kevés, bizonytalan régészeti anyag köthető. ${ }^{410}$ Bár a források nem említik konkrétan a langobardok esetében, hogy az avar hadsereg részét képezték volna, ennek ellenére valószínűsíthető, hogy ha kis számban is, de részt vehettek az Avar Kaganátus hadjárataiban.

\section{2. 5. Csatajelenetek Priskos 599-es hadjáratából}

Az Avar Kaganátus korai szakaszában, az avar-bizánci háborúk időszakában az összecsapások döntő többségét természetesen az avarok Bizánci Birodalom ellen vezetett

\footnotetext{
${ }^{407}$ Ezzel a megfigyeléssel kapcsolatban Kiss P. Attila mutatott rá egy fontos momentumra. Véleménye szerint ezt a differenciát föként a „forrásadottságbeli különbségek” okozzák: a hunok vezetőrétegének „etnikai” összetételére a gót származású Iordanes tért ki. Az avaroknál viszont nem áll rendelkezésünkre olyan szerző, akinek germán származása révén érdekében állt volna kitérni ilyen dolgokra (Kiss P. 2010b, 125).

${ }^{408}$ 615-616 táján a friauli hercegség sikeres támadásakor langobard foglyokat hurcoltak az avarok a Kárpátmedencébe (PAulus Diaconus IV. 37-38. vö. Galamb 2012, 138-143). 661-ben pedig Perctarit korábbi langobard király rövid idöre az avar kagánhoz menekült (PAULUS DiACONUS IV. 51; V. 2. vö. Galamb 2012, $148-150)$.

${ }^{409}$ A trákiai sziget beazonosítása problematikus. Szádeczky-Kardoss Samu felveti annak a lehetőségét, hogy ez a sziget esetleg a Viminacium előtt fekvő Duna-szigettel azonosítható, bár ez a terület Trákiától nyugatabbra fekszik (SZÁDECZKY-KARDOSS 1998, 135).

${ }^{410}$ Rosner Gyula a Szekszárd-Bogyiszló temető néhány sírját langobard etnikumhoz köti (RoSNER 1999, 154-156). Straub Péter pedig a Keszthely kultúra esetében feltételez langobard elemeket (STRAUB 1999, 195-224).
} 
hadjáratai képezték. Egyetlen hadjárat kivétel ez alól, amikor is 599-ben Priskos fővezér vezetésével a bizánci sereg sikeres támadást indított az avarok ellen, több csatában megverte az avar kagánt és fiait; és mélyen benyomult az Avar Kaganátus területére. Theophylaktos Simokattés részletesen megörökítette ezt a hadjáratot történeti munkájában, emellett további három kései szerzőnél is fennmaradt az esemény rövidebb leírása (Theophanes, Cedrenus, Nikephoros Callistos Xanthopulos). Ez utóbbi szerzők müveinek forrásértéke azonban igen csekély, ugyanis vagy Theophylaktos Simokattéstöl, vagy pedig egymástól vették az adataikat.

Miután Maurikios császár az avarokkal 599 tavaszán kötött békét semmisnek tekintette, Komentiolos és Priskos vezérletével megindult a bizánci sereg az avarok ellen. A bizánciak Viminaciumnál (ma Stari Kostolac, Szerbia) tervezték a Dunán való átkelést, és itt, a Viminacium melletti dunai szigeten rendezte be a két vezér az első főhadiszállását. Az avarok észlelték a bizánciak hadi készülődését, és a kagán a bizánci területek ellen vonult, míg a korábbi pestisjárványt túlélő négy fia a dunai átkelőhelyeket próbálta tartani. Azonban a tutajokon, hajókon átkelő bizánciak legyőzték a Duna bal partját védő avarokat (TheOPHYLAKTOS SimoKATtÉS VIII. 2, 3-4. vö. Olajos 2012, 269). A két avar sereg közül a Bizánci Birodalom területét támadó egységnek valószínüleg az volt a célja, hogy elterelje a figyelmet az avar fennhatóság alatt álló területekről, és így rábírja Priskost, hogy forduljon vissza, és a limesen belüli részek védelmével foglalkozzon. Az avar kagán terve nem valósult meg, a forrásban a továbbiakban nem szerepel ez az egység. Feltehetően viszonylag rövid időn belül csatlakozott a Duna bal partján védekező seregrészekhez. Komentiolos azonban betegségre hivatkozva a továbbiakban nem vett részt a hadjáratban, ${ }^{411}$ így a hadsereg irányítása teljes mértékben Priskosra hárult (THEOPHYLAKTOS SiMOKATTÉS VIII. 2, 5-7. vö. Olajos 2012, 269-270).

A Duna északi partját elfoglaló bizánciak először erődített tábort építettek. Priskosnak a Duna északi partjára történő megérkezése előtt az avarok ki akarták használni, hogy a bizánciak fővezéri irányítás nélkül vannak, és támadást intéztek a táboruk ellen. Az ennek az avar támadásnak a hírére megérkező Priskos vezetésével készültek fel az első összecsapásra a bizánciak. Priskos a Duna bal partján elhelyezkedő tutajokat és csónakokat visszaküldte a dunai szigetre. Az volt a célja ezzel az

\footnotetext{
411 Komentiolos a harcoktól történő távolmaradását Theophylaktos gyávaságával magyarázza (TheOPHYLAKTOS SimoKaTtés VIII. 2, 5. vö. Olajos 2012, 269). Olajos Terézia úgy véli, hogy a bizánci szerző ezen értesüléseit Priskos egyik hívének hadinaplójából szerezhette. Olajos Terézia feltételezi, hogy Komentiolos nem kívánt ezen hadjáratban másodlagos szerepet játszani Priskos fövezér mellett. Mivel a harci sikerek a fövezér presztízsét növelték, így a Komentiolos úgy gondolkozhatott, hogy neki, mint Priskos riválisának nem érdeke a bizánci haderő sikere (OLAJOs 2012, 270)
} 
intézkedéssel, hogy a bizánci katonákat az újonnan épített táborban tartsa, és ne hagyják el engedély nélkül a Duna bal partját, nehogy meggyengüljön a tábor védelme (TheOPHYLAKTOS SimoKATtÉS VIII. 2, 8-10. vö. Olajos 2012, 270). Érdekes momentum Priskosnak ez az intézkedése, hogy a hajókat és tutajokat átküldte a túlpartra. Ezzel ugyan lehet, hogy megakadályozta a bizánci katonák illegális táborelhagyását, de emellett jóval sebezhetőbbé tette saját seregét. A bizánci auktor a hadjárat első periódusában többször erőteljesen hangsúlyozza a tábor védelmét, úgy tünik tehát, a bizánciak is tartottak attól, hogy egy esetleges vereség esetén a sereg komoly veszélybe kerülhet.

Az első összecsapásra Priskosnak a Duna bal partjára történő érkezésétől számolva a negyedik napon került sor. Az avar hadsereg több kisebb, pontosabban 15 egységre osztva támadott, a bizánciak pedig három csapatba tagolva harcoltak. Theophylaktos nem részletezi az összecsapást, csak annyi derül ki, hogy az avarok minden oldalról támadtak, és a bizánciak távolharc helyett inkább a lándzsás közelharcot részesítették előnyben. Az avarok fegyverzetére, a harcmodorára azonban nem utal a szerző. A bizánci forrás szerint a küzdelem Priskos seregének győzelmével végződött, és főként az avaroknak voltak jelentős veszteségeik (TheOPHYLAKTOS SiMOKATTÉS VIII. 2, 10-12. vö. Olajos 2012, 270). ${ }^{412}$ Theophylaktosnak az avarok seregfelépítésről adott leírása a Maurikios Stratégikon című munkájában található általános jellemzéssel függ össze. Vagyis az avar sereg más nomád népekéhez hasonlóan több egységből épült fel, amelyek nem egységes arcvonalban álltak fel, hanem különböző taktikai utasításokat hajtottak végre (MAURIKIOS II. 1, 6-7. vö. SZÁDECZKY-KARDOSS 1998, 81). Theophylaktos munkájából azonban nem derül ki, hogy mik voltak ezek. A bizánci szerzőnek abból az utalásából kiindulva, hogy minden oldalról támadtak, valószínüsíthető, hogy be akarták keríteni Priskos seregét. Ezzel a felállással szemben a bizánci sereg klasszikus, jobb és bal szárny, valamint középvéd szerkezetet mutat, melyek egységes arcvonalban álltak fel az ellenséggel szemben (TheOPHYLAKTOS SimOKATTÉS VIII. 2, 10. vö. Olajos 2012, 270).

A második csatájuk alkalmával a bizánci sereg szintén három egységre tagolva harcolt, a szárnyak erőteljes széthúzásával bekerítette az avarokat. Az ütközet ezúttal is bizánci győzelemmel és jelentős avar veszteséggel zárult (THEOPHYLAKTOS SIMOKATTÉS VIII. 3, 1-3. vö. Olajos 2012, 270-271). ${ }^{413}$

\footnotetext{
${ }^{412}$ Theophylaktos szerint 4 ezer avar és 300 bizánci esett el a csatában (THEOPHYLAKTOS SIMOKATTÉS VIII. 2, 12. vö. Olajos 2012, 270).

${ }^{413}$ A bizánci auktor szerint 9 ezer avar esett el ebben a csatában (THEOPHYLAKTOS SiMOKATTÉS VIII. 3, 3. vö. Olajos 2012, 271).
} 
A harmadik összecsapásukra a tizedik napon került sor. A bizánciak ez esetben is három egységben harcoltak, és földrajzi szempontból kedvezőbb fekvésü területekről, magaslatról ${ }^{414}$ és hátszélben támadtak az egy tömbben harcoló avarok ellen. ${ }^{415}$ Priskos serege a környező vizes, mocsaras területre szorította az avar sereget. Ez az ütközet is avar vereséggel és jelentős avar veszteséggel ért véget, ${ }^{416}$ a kagán fiai is elestek a harcban (TheOPhylaktos Simokattés VIII. 3, 4-7. vö. Olajos 2012, 271). A mocsaras terület lokalizációja kapcsán több lehetőség is felmerül a kutatásban: Viminaciumtól északabbra, a Temes és Béga alsó folyásához helyezik, esetleg Viminacium közelébe, a dél-bánsági Kevevára és Alibunár települések környékére teszik a kutatók (POHL 1988, 156; OLAJOS 2012, 271).

A vereségeket követően a kagán északnyugati irányba, a Tissos folyóhoz menekült, ${ }^{417}$ Priskos pedig seregével együtt követte, és a következő összecsapásra a viminaciumi harcok után egy hónappal került sor. A kagán és Priskos ebben az esetben előzetesen megegyeztek az ütközet időpontjában. ${ }^{418} \mathrm{~A}$ bizánci fővezér átalakította a csatarendjét: a bal oldali csatasort a jobb oldalra állította, a középsőt pedig balra. ${ }^{419} \mathrm{~A}$ tizenkét különálló csapategységgel hadrendbe álló avarok azonban ezúttal is kudarcot vallottak (THEOPHYLAKTOS SIMOKATTÉS VIII. 3, 8-10. vö. Olajos 2012, 271). Walter Pohl ezt a csatát erőteljesen kiemeli, véleménye szerint ebben az esetben igazán nagyszabású

\footnotetext{
${ }^{414}$ Pohl szerint ez a magaslat egy római sánc lehetett Alibunár (ma Alibunar, Szerbia) és Kevevára (ma Kovin, Szerbia) között (PoHL 1988, 156).

${ }^{415} \mathrm{Az}$ avarok egységes hadrendje kapcsán párhuzamként hozható fel Maurikios azon híradása, ami szerint az avar hadsereg felállásakor csapategységeik, ezredeik egységes arcvonalnak tünnek (MAURIKIOS XI. 2, 12. vö. SZÁDECZKY-KARDOSS 1998, 83), amelyek a későbbiekben válnak szét. Valószínűleg az avaroknak ebben az esetben már nem volt idejük és lehetőségük külön csapaegységekre válni, és a különböző taktikai elemeiket végrehajtani.

${ }^{416}$ A forrásban 15 ezer elesett avar harcosról van szó (THEOPHYLAKTOS SimOKATTÉs VIII. 3, 7. vö. Olajos 2012, 271).

${ }^{417}$ A Tissos folyó azonosításakor a Tisza mellett a Temes folyó is felmerül, azonban a kutatók szerint valószínűbb, hogy ez a név inkább a Tiszára vonatkozhat (PoHL 1988, 156; OlAJOs 2012, 271).

${ }^{418}$ Ez azonban nem meglepő jelenség, mint ahogy azt Pohl kommentálja (PoHL 1988, 156). Általános jelenségnek tekinthető a középkor folyamán, hogy a felek megegyeznek a csata időpontjában (OLAJOS 2012, 271; OLAJOS 1977, 5-9).

${ }^{419}$ Bár kicsit homályos a hadrend átalakitásáról szóló rész Theophylaktos munkájában, mégis úgy tünik, hogy Epameinondas, a Kr. e. IV. században élt thébai hadvezér hadászati taktikáját alkalmazta a bizánci hadvezér. Ennek a lényege, hogy szakít azzal a régi harcászati elvvel, miszerint a győzelmet az egész arcvonalon, egyszerre, egy időben és egyenlő mértékben kellene elérni. Ehelyett a katonai döntést mindig csak az egyik szárnyon (általában a jobbszárnyon) igyekezett elérni. Tehát erre a szárnyra csoportosította a katonái jelentős részét, és mélységében a jobb szárny jóval több sorból állt (HAHN 1963, 55, 57). Ezzel párhuzamosan érdemes megjegyezni, hogy Priskos a csatában történő intézkedései kapcsán Olajos Terézia hívta fel a figyelmet arra, hogy az árulónak tartott és Theophylaktos munkájában általában negatív színben feltünő Komentiolos az általa vezetett 598-as vesztes iastrosi csata elején ugyanezeket az intézkedéseket hozta meg (OLAJOs 2012, 258, 271). Theophylaktos szerint Komentiolos a csatarendet teljesen összezavarta, a csatasor közepéről a bal szárnyra helyezett át katonákat, a bal szárny katonáit pedig a jobb oldalra irányította (TheOPHYLAKTOS SimOKATTÉS VII. 14, 2. vö. Olajos 2012, 258). Valószínüleg ez esetben is Priskosnál alkalmazott taktikai elemröl lehet szó.
} 
ütközetről lehetett szó, melyre az avar-bizánci háborúk időszakában nagyon kevés példa akad (PoHL 1988, 156).

A csatát követően Priskos négyezer főnyi csapatot küldött a Tissos túlpartjára, hogy figyeljék meg az avarok hadmozdulatait. ${ }^{420} \mathrm{Ez}$ az egység a felderítés során három, avar fennhatóság alatt álló gepida település alkoholmámorban úszó lakosságát támadta meg, és jelentős részüket megölte (THEOPHYLAKTOS SiMOKATTÉS VIII. 3, 11-12. vö. Olajos 2012, 272).

A bizánci felderítő hadmozdulatokat követően került sor az utolsó ütközetre, aminek a jelentőségét emeli ki Theophylaktos a legjobban, melyre az utolsó vereséget követően húsz nap múlva került sor. Azonban a forrásból csak annyit tudunk meg, hogy az avar sereg nagy részét a folyóba szorították, sokan megfulladtak, és jelentős számú „barbárt” ejtettek foglyul (TheOPHYLAKTOS SIMOKATTÉS VIII. 3, 13-15. vö. Olajos 2012, 272).

Theophylactos Simocatta a sikeres hadjárat kapcsán a legtöbb csataleírás után közölte mindkét fél veszteségeit. Ezen számadatokat - mint ahogy a korszak más szerzőinél szereplőket - a kutatók döntő többsége erősen túlzónak tartja. Ha szó szerint vesszük Theophylaktos Simokattés adatait, akkor az avaroknál (beleértve a segédnépeket is) legalább 58200 fő volt a halottak száma. Ezzel szemben Bóna István - aki behatóan foglalkozott az avar hadsereg létszámával - hozzávetőlegesen 100 ezer före becsülte az avar férfilakosság számát.

Összegezve a leírtakat, a Priskos által vezetett 599-es hadjárat az avar-bizánci háborúk időszakának példa nélküli eseménye volt. Ez az egyetlen alkalom, amikor a Bizánci Birodalom több győztes csatát vívott az avarok ellenében a kaganátus területén, és sikerült viszonylag mélyen benyomulnia avar területekre. A diadalmas hadjárat eredményét, az erőfölényt azonban a bizánciak nem tudták kihasználni, mivel Priskos győzelme után rögtön belső válság tört ki a Bizánci Birodalmon belül. Ennek következtében a Maurikiost követő Phókas császár (602-610) a perzsa támadás miatt kénytelen volt békét kötni az avarokkal, azért, hogy elkerülje a kétfrontos háborút.

\footnotetext{
${ }^{420}$ Felmerül a kérdés, hogy Priskos miért nem használta ki a győzelmeit, és miért nem nyomult beljebb az Avar Kaganátus területére, hogy végső csapást mérjen az avarokra. Walter Pohl az avar helyzetet hasonlítja a perzsával. Véleménye szerint Priskos döntése azzal magyarázható, hogy míg például a perzsáknál „elegendő” volt a perzsa fővárosba benyomulni, és megdönteni az uralkodó hatalmát, addig az avar kagán esetében a vesztes csaták sem rázták meg az avar uralkodó pozícióját oly módon, hogy összeomoljon a birodalma (POHL 1988, 157). Mindenestre megállapítható a korábbi analógiák alapján, hogy a letelepült birodalmak nomád birodalmak területére benyomuló hadseregeinek hadjáratai nem vagy csak rövid ideig tartó sikereket hoztak. Erre jó példa Dareios szkíták elleni hadjáratának teljes kudarca (HÉRODOTOS IV. 122-142. vö. Muraközi 2000, 308-316).
} 


\section{3. Összegzés}

Az avarok fegyverzetét említő források müfaja kapcsán fontos hangsúlyozni, hogy az egyik legfontosabb munkánk Maurikios Stratégikon címü müve, annak ellenére, hogy több esetben is toposzokkal él a szerző. További adatokat találunk még történeti munkákban, krónikákban, költeményekben, egyházi beszédekben, legendákban, évkönyvekben, levelekben és egy rendeletben. A különböző forráscsoportok vizsgálatakor megállapítható, hogy a források a kora és késő avar kor szempontjából nem egyenlő arányban oszlanak el. A kora avar korszak fegyverzetéről az írott és a régészeti anyagból nyerhető adatok állnak a rendelkezésünkre. Ezek az információk egymást kiegészítve használható ismereteket szolgáltatnak a bizánci-avar korszak fegyverzetére. A késő avar korszak fegyverzetére vonatkozólag fellelhetők írott és régészeti források, valamint képi ábrázolások. Ebből az írott források adatai - a bizánci-avar háborúk korához képest - kisebb számban szerepelnek, és nehezebb belölük következtetéseket levonni.

A bizánci-avar háborúk időszakára legjobb forrásértékkel bír tehát e témában Maurikios hadászati munkája, amelyben felsorolja az avarok legjellegzetesebb fegyvereit, az általa használt terminusokból következtethetünk ezek típusaira is, amit a régészeti adatok is alátámasztanak. A többi szerző munkái kapcsán többnyire az általuk említett fegyver használatára következtethetünk az avar hadseregben, ezen belüli típusra csak néhány esetben.

A forrásokban a fegyverek említése többféle kontextusban figyelhető meg. A már többször említett Stratégikon általános jellemzést ad az avarok harcmodoráról. Szintén jelentősek azoknak a szerzőknek a munkái, akik a fegyvereket konkrét használat közben említik meg. Semmilyen forrásértékkel nem bírnak viszont azok a híradások, melyek vagy csak a fegyver szó szinonimájaként használnak bizonyos fegyverneveket, vagy pedig szimplán „töltelékszóként” alkalmazzák ezeket a szavakat. Ez utóbbira számos példát találunk az avarok kapcsán (például THEOPHYLAKTOS SIMOKATTÉS II 16, 12; VII 9, 12; MANASSES 3523-3549; ZONARAS XIV 13, 7-23; GEÓRgIOS PISIDÉS 328-339).

Az íj és nyíl felépítésére, szerkezetére, típusaikra nem nagyon utalnak a források, kizárólag a régészeti anyagból tudjuk rekonstruálni őket. Az auktorok ezt a két fegyvertípust említik a legritkábban az avaroknál, csak a régészeti leletekből következtethetünk ezek szerkezetére, jelentőségére. Az avarok vágófegyvereiről ugyanakkor számos forrás emlékezik meg. Az auktorok híradásaiból a hosszú, egy- és 
kétélü kard meglétére egyértelműen következtethetünk, melyek használatát a régészeti adatok is alátámasztják. A régészeti anyagban megfigyelhető saxokra utal a frank-avar háborúk időszakában egy forrásban található terminus. Ebben az időszakban azonban már ezt a terminust annyira általánosan, konkrét jelentés nélkül használják a szerzők, hogy pusztán ebből az adatból nem következtethetünk belőle konkrét típusra, annak ellenére, hogy a régészeti adatok alátámasztják a használatát. A régészeti anyagban a közép avar korszaktól megfigyelhető szablyákra utaló kifejezés sem lelhető fel az írott forrásokban. Ez esetben fontos hangsúlyozni, hogy sem a latin, sem a görög nyelvben nem használtak olyan terminust, mely egyértelmüen a szablyára vonatkozott volna. A vágófegyverek gyakorlati jelentőségét mutatja az is, hogy az auktorok híradásában megfigyelhető ezeknek fegyvereknek a szimbolikus szerepe is az avarok körében. Szintén több szerző emlékezik meg az avarok lándzsáiról, azonban elsősorban Maurikios müve szolgáltat hiteles adatokat a lándzsára vonatkozólag. Az általa használt кovtópıov kifejezésből nem lehet egyértelmüen eldönteni, viszont jellemzéséből következtetni lehet arra, hogy voltak döfőlándzsáik is. Erre a korszakra vonatkozólag a leletanyagból viszont egyértelmüen bizonyítható a páncéltörő döfőlándzsa. Az ütő- és sújtófegyverek közül a balták egyszer tűnnek fel az írott forrásokban a bizánci-avar háborúk időszakában, ez esetben azonban megállapítható, hogy nem fegyverként használták őket. A régészeti anyagban azonban egyértelmüen tetten érhető a használatuk az egész avar koron át. A parittyák - szerves anyagból való felépítésük folytán - csak az írott forrásokban tünnek fel, a bizánci-avar és a frank-avar háborúk időszakában egy-egy forrás említi meg ezek használatát. A források adataiból úgy tűnik, hogy egyszerübb felépítésű eszközről lehetett szó. Ezt a fegyvert valószínűleg Bizáncból vagy valamelyik nyugat-európai néptől vehették át az avarok. Az avarok vértezete kapcsán a bizánci-avar háborúk időszakában Maurikios közléséből ( $\zeta \alpha ́ \beta \alpha)$ egyértelműen kitűnik, hogy az avar hadseregben alkalmazták a sodronypáncélt, amit a régészeti adatok is alátámasztanak. Még három másik írott forrás (Theodóros Synkellos és Menandros Protéktór munkái, Miracula S. Demetrii) is utal az avarok fémvértezetére, de nem dönthető el a leírásokból egyértelműen a fémpáncél típusa. A régészeti anyag alapján viszont bizonyítható, hogy az avaroknak a sodronypáncélon kívül volt még lemez- és kombinált páncélzatuk (sodrony és lemez), és a lemezes vért volt a legelterjedtebb a leletanyagban. A frank-avar háborúk időszakára az írott források közül a 805-ös dietenhofeni rendeletből kikövetkeztethető, hogy ebben az időszakban az avarok használhattak frank típusú lemezpáncélt is. A bizánci-avar háborúk korszakának sisakhasználatáról írott forrásos és régészeti adatok állnak a rendelkezésünkre. A 


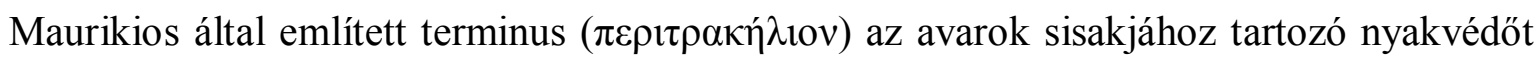
jelöli. Theodóros Synkellos müvéből megállapíthatjuk - míg Maurikios csak közvetve utal rá -, hogy az avaroknak volt fémsisakjuk is ( $\pi \varepsilon \rho \iota \varepsilon \varepsilon \varphi \alpha \lambda \alpha i ́ \alpha)$, a forrásban található kifejezés félgömbös, pántos vagy hegyesedő kónikus alakú típusra utal. Az előbbi típus meglétét támasztja alá a kora avar kori régészeti leletanyag. A késő avar korra vonatkozóan a nagyszentmiklósi kincs ,győztes fejedelem” ábrázolása szolgáltat jó információkat a vértezetről: sodronypáncél, lemezekből szegecselt pántos sisak, vállat, fület, tarkót takaró sodronycsuklya. Kevés információnk van az avarok pajzshasználatáról. A bizánci-avar háborúk időszakában az írott források (Miracula S. Demetrii, Geórgios Pisidés, Menandros Protéktór, Maurikios) által említett pajzsterminusok ( $\sigma \kappa o v \tau \alpha ́ \rho ı v, ~ \theta v \rho \varepsilon o ́ \varsigma, ~ ' \alpha \sigma \pi i ́ \varsigma)$ a pajzsra általában vonatkoznak, nem jelölnek konkrét típust. Csupán Menandros Protéktór utalásából következtethetünk arra, hogy az avaroknak könnyüszerelékes, fából készült, bőrrel bevont pajzsaik (is) lehettek. A frank-avar háborúk időszakából esetlegesen csak képi ábrázolásokból következtethetünk az avarok pajzshasználatára. Maurikios és Theodóros Synkellos egybehangzó híradásából tudjuk, hogy az avar hadsereg lovainak egy része rendelkezett vértezettel. A kifejezések azonban nem utalnak konkrét páncéltípusra

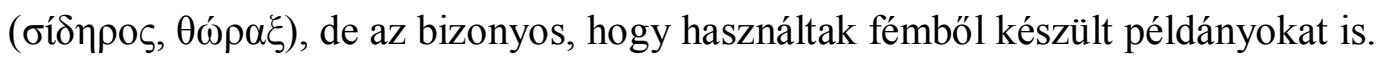

A hadjáratokra történő felkészülésre, a hadsereg felvonulására vonatkozóan az avarok esetében több forrás szolgáltat adatokat számunkra. Maurikios munkájából egyértelműen kitűnik, hogy az avaroknál, hasonlóan más nomád népekhez, a vadászat lényegében „hadgyakorlatnak” számított. Szintén Maurikios utal általánosságban az avar hadseregen belüli fegyelemre, a hadászatban jártas szerző azonban nem tér ki erre a témára részletesebben. A Bizánc elleni sikeres hadjáratok egyik előfeltétele volt, hogy az avaroknak széles körü ismeretei legyenek a birodalomról. Valószínüsíthető, hogy az avarok is rendelkezhettek különböző felderítő egységekkel. Maurikios azonban ebben a kérdésben is csak általánosságban nyilatkozik, miszerint „ügyesen kilesik” a megfelelő helyzetet, és azt ki is használják. Az írott forrásokból továbbá kitünik, hogy a számukra ismeretlen terepen ,útikalauzok” segítségét vették igénybe, valamint a bizánci seregből elfogott foglyoktól szereztek információkat az ellenség hadseregére, hadmozdulataira vonatkozóan.

A sereg vonulását akadályozó folyón történő átkelést többféle módon oldották meg. Kisebb folyók esetén egyszerűen átúsztattak a lovaikon, nagyobb folyók esetében télen a befagyott vizen keltek át. Több helyen tetten érhető a forrásokban, hogy az avarok a velük szövetséges népek segítségét vagy alávetett segédnépük szakértelmét vették igénybe a 
folyón történő átkelésben. A szövetséges népek közül a bizánciakról és a langobardokról vannak adataink. Az alávetett segédnépek közül pedig a szlávok esetében figyelhető meg ez a jelenség. A bizánciak hajók biztosításával és hidak építésével járultak hozzá az avarok folyón történő átkeléséhez szövetségi viszonyuk időszakában. A langobardok hajóépítő ácsokat biztosítottak az avarok számára egy alkalommal. Az avar hadsereg alávetett szláv egységei pedig egyszerü fatörzsböl kivájt csónakokat szolgáltattak az avar hadsereg számára. A szövetségesek és az alávetett segédnépek mellett azonban az is megfigyelhetö az auktorok munkáiban, hogy az avarok saját maguk is alkottak vízi eszközöket. Maurikios a „szkíta” módra történő hídépítésre hívja fel a figyelmet. Ezenkívül Sirmium ostrománál találkozunk azzal az írott forrásokban, hogy a Száván átívelö híd építésében avarok is részt vettek.

A hadjáratokon lévő avar hadsereg is többféleképpen oldotta meg az utánpótlás problémáját. Egyrészt a hadjáratok során zsákmányolásból biztosíthatták az utánpótlásuk egy részét. Másrészt a számukra szükséges dolgokat magukkal is vihették. Arra vonatkozóan is megfigyelhető példa, hogy a békekötések alkalmával biztosítottak maguk számára ellátmányt, valamint más népekkel szövetségben vezetett hadjárat esetében a szövetséges társuk is gondoskodhatott az avar hadsereg ellátmányáról.

A csaták közbeni jelenségekre számos példát találunk az írott forrásokban. Az avar hadsereg támadásidőpontjának a megválasztása esetében megfigyelhető, amiről Maurikios ír, hogy hirtelen, meglepetésszerű támadást indítanak az avarok éjszaka. Ezzel párhuzamosan az a középkorban általános jelenség is tetten érhető, miszerint a felek elöre megbeszélték a támadás időpontját. Hasonlóan más nomád és nem nomád népekhez az avarok is bevetettek különböző cseleket a győzelem érdekében.

Az avarok hadrendjéről szintén Maurikios tájékoztat minket, véleménye szerint az avarok nem egy egységes hadrendbe szerveződnek, hanem több egységre oszlanak, melyek egymástól függetlenül hajtják végre a megadott taktikai utasításokat. Néhány esetben más bizánci szerzőnél konkrét csatajelentek kapcsán is megfigyelhető ez a rendszer. Az auktorok több esetben utalnak az avar hadsereg létszámára is, melyekből a középkori források megbízhatatlansága folytán nehéz az avar sereg valós állományára következtetni. Ami azonban kitünik a fent nevezett forrásokból, hogy az avarok hadi szerveződése is a tízes rendszeren alapult.

Több auktor munkája utal arra, hogy az avarok a csaták közben kiáltásokat, különböző hangadásokat és a kürtjeleket használtak. Ezek többféle funkciót tölthettek be. Egyrészt az ellenség megfélemlítésére, saját „harci kedvük feltüzelésére” szolgálhattak, 
valamint pedig az avar hadseregen belüli csapategységek közötti kommunikációra, katonai jelzések továbbítására. Az avar hadsereg katonai jeladásai közül az írott forrásokban leghangsúlyosabban a kürtök szerepe figyelhető meg, melyek az avaroknál a hadba vonulás jelképeként, valamint a kagán harci jelvényeként értelmezhetőek. Továbbá a néma jelekhez a zászlók és a korbácsok sorolhatók. Előbbi hadijelvényként is szolgált. A pszichológiai hadviselés egyik formájaként értelmezhető az az avaroknál is megfigyelhető jelenség, hogy nagyobb létszámúnak próbálják feltüntetni a hadseregüket az ellenség szemében, mint amekkora valójában. Erre vonatkozóan Maurikios Stratégikon címü munkájában találunk jó adatokat, aki a tartalék lovak ilyen szerepét is hangsúlyozza. Az avaroknál megfigyelhető az is, hogy különböző varázslási praktikákhoz is folyamodtak a győzelem elérése érdekében. Az avar hadsereg táborának a védelméről Maurikios emlékezik meg, aki szerint nem létesítenek körülárkolt tábort, viszont őrszemeket állítanak, amivel biztosítják, hogy ne érje őket rajtaütés. Továbbá az írott források adataiból következtethetünk arra is, hogy az avarok használták a szekérsáncot táboraik védelméül.

A bizánci-avar háborúk időszakában több forrás is megemlékezik az avar hadsereg elővédjéről. Ezekből egy forrás utal egyértelmüen arra, hogy ezt az egységet alávetett szlávok alkották az avar hadseregben. A könnyüfegyverzetű lovasság esetében megfigyelhető, hogy az auktorok kevésbé hangsúlyozzák ennek az egységnek a szerepét az avar hadseregben. Ez azonban nem jelenti azt, hogy ne lett volna jelen. Az avarok könnyüfegyverzetü lovasságának taktikai repertoárjában - Maurikios interpretálásában megfigyelhető a lesben állás, a bekerítés, a színlelt megfutamodás és az ék alakú (szétszóródó) alakzat. Az a jelenség azonban, hogy a színlelt megfutamodás a bekerítés taktikájával párosul, először az avaroknál figyelhető meg az írott forrásokban. Továbbá a könnyüfegyverzetü lovasság egy jellegzetes eszközének tekinthető a felperzselt föld taktikája. Felmerült a kutatásban, hogy a frank-avar háborúk időszakában Nagy Károly 791-es hadjáratakor az avarok ezt a stratégiát alkalmazhatták, azonban a kutatók álláspontja ez ügyben nem egyöntetü. Az írott források adataiból egyértelmüen tetten érhető az avarok nehézfegyverzetű lovassága, úgy tünik, hogy a bizánci-avar háborúk időszakában nőhetett meg ennek az egységnek a szerepe, a későbbiekben pedig csökkent a jelentősége az avar seregben. A frank-avar háborúk időszakában továbbá számolhatunk azzal, hogy egy-egy frank eredetű, nehézfegyverzetű lovasságra jellemző fegyvertípust is átvehettek az avarok nyugati hatásra. Az avar hadsereg gyalogságára vonatkozóan Maurikios munkájában figyelhető meg az a toposz, hogy az avarok nem képesek 
gyalogosan harcolni és járni sem. További írott forrásokból elsősorban a szlávok és feltehetően a gepidák gyalogos harcmodora érhető tetten egyértelmüen.

Az avar hadsereg a népesség-összetétel szempontjából is sokszínű, változatos képet mutat az írott források alapján. Egyértelmüen bizonyítható, hogy az avarok segédnépeihez tartoztak kutrigurok, bulgárok, szláv népek, gepidák. Nem zárhatók ki teljesen azonban a szabir, az utigur és a langobard elemek sem. Erről azonban csak a bizánci-avar háborúk időszakában vannak adataink. Az írott források tanúsága szerint - ellentétben a hunokkal alávetettjeik főként „,névtelenek”, vagyis a segédnépek vezetői közül egy sem töltött be fontos szerepet a kagán szükebb környezetében. Harcmodor tekintetében arra következtethetünk, hogy az alávetett népek részt vettek az ostromokban. A nomád népeknél elsősorban könnyü- és nehézfegyverzetű lovassággal, a szláv nyelvü népeknél és valószínüleg a gepidáknál pedig könnyü- és nehézfegyverzetü gyalogsággal számolhatunk.

$\mathrm{Az}$ avar hadseregre vonatkozó írott források áttekintése után megállapítható, hogy az avarok erődített helyeket csak a kora avar korszak első felében, a Bizánci Birodalom elleni támadások időszakában próbálták bevenni. Elsősorban három sikertelen ostrom kapcsán (Thessalonike kétszer, illetve Konstantinápoly) vannak jó adataink az avarok ostromgépeiről. Megállapítható, hogy az erődített helyek kiéheztetése és hirtelen lerohanása, a városok csellel történő bevétele mellett ostromgépeket is alkalmaztak. Megfigyelhető, hogy egy-egy városostrom esetében több ostromtechnikai fogást is alkalmazhattak az avarok. Például Sirmiumnál a kiéheztetés mellett csellel próbálták megtéveszteni az ellenséget. A hajítógépek típusai közül az avaroknál egyértelmüen csak a kínai egyszerü típusú kőhajítógép bizonyítható. Emellett nem zárható ki a torziós kő- és nyílvetőgépek használata sem. Ostromaik kapcsán szintén fontos szerepet kaptak a fából készült, valószínüleg többszintes ostromtornyok, a faalapú, megvasalt faltörő kosok, melyek keretbe voltak felfüggesztve. Ezenkívül használtak még ostromtetőket, amelyek segítségével az avar hadsereg könnyebben megközelíthette a városfalat, és biztonságban rongálhatta a fal alapzatát. Valószínűleg a létráknak csak az ostrom végén jutott főszerep, amikor a védők nagy részét sikerült a városfalakról eltávolítani egyéb ostromeszközökkel. Tenger- vagy folyóparti település esetében fapadozat, híd építésével vagy csónakok bevetésével próbáltak a vízfelületen is támadni. 


\section{Következtetések}

A hunokra és az avarokra vonatkozó kútföket vizsgálva megállapíthatjuk, hogy az 567-ben a Kárpát-medencét elfoglaló nomád nép harcmodoráról, fegyverzetéről több auktor emlékezik meg (hunok esetében huszonegy, az avarok esetében pedig huszonnyolc munka). A rendelkezésünkre álló források időbeli eloszlása teljesen különböző a két népnél. Ugyanis míg a Hun Birodalom esetében - annak ellenére, hogy volt forrásszegényebb időszak is - szinte a teljes fennállása idejéből vannak adataink a hunok fegyverzetéről, harcmodoráról, addig az avaroknál teljesen más a helyzet. A források döntő többsége az Avar Kaganátus korai korszakának, a bizánci-avar háborúk idejének harcmodorára vonatkozóan ad számunkra tájékoztatást. A 7. század második felétől a 8. század végéig terjedő időszakról semmilyen híradásunk sincs erre a témára vonatkozólag. A 8. század végén, a frank-avar háborúk idején pedig csak néhány adatunk van. Tehát lényegében az avaroknál is csak egy rövidebb időszakra vonatkozólag szolgáltatnak több adatot a harcmodorra, fegyverzetre a kútfők. Jelentős különbséget észlelhetünk a hunokat és az avarokat említő források müfaját illetően. Míg a hunok fegyvereit és harcmodorát említő kútfők döntő többsége történeti munka és költemény, addig az avarok kapcsán sokkal változatosabb a helyzet. Történeti munkákon és költeményeken kívül még különböző teológiai müvekben (szentbeszéd, legendák stb.), évkönyvekben, levelekben, egy frank rendeletben és egy hadászati kézikönyvben találhatunk az avarok fegyverzetéről és harcmodoráról adatokat. Ezek közül kiemelendő Maurikios Stratégikon című munkája, a hunok és az avarok közül csak az avar hadsereg kutatása esetében áll a rendelkezésünkre ilyen témába vágó, speciálisan hadászattal foglalkozó mü. Emellett azonban érdekes jelenség, hogy míg a hunok esetében az auktorok nagyon gyakran adnak általános jellemzést a harcmodorukról, fegyverzetükről, addig az avaroknál csak Maurikiosnál találunk általános ,ismertetőt” ebben a témában.

Az írott forrásokban a hunok fegyverzete kapcsán megfigyelhető az íj és a nyíl mellett a lándzsa, a vágófegyver, a pányva és a védőfegyverzet. Nem említik meg az auktorok az ütő- és sújtófegyvereket, és ezek használatát a régészeti leletek sem támasztják alá. Az avarok fegyverzetéről a kútfőkben az íjról, a nyílról, a vágófegyverről, a lándzsáról, az ütő- és sújtófegyverről, a parittyáról és a védőfegyverzetről találunk adatokat. A felsorolt fegyverek alkalmazását - a pányva, a parittya és a lovak vértezetének kivételével - a régészeti leletek is alátámasztják, és a legtöbb esetben pontos információt nyerhetünk a 
fegyver szerkezetéről, felépítéséről, típusairól. Szervesanyag alkotóelemeikből kifolyólag a pányva és a parittya használata csak az írott forrásokban érhető tetten. A pányva a vizsgált két nomád nép közül csak a hunoknál figyelhető meg, ez tipikusan jellegzetes nomád eszköznek tekinthető, melynek a használatát átvették a letelepült népek is Kelet-Európában a szarmatáktól, vagy az alánoktól, vagy a hunoktól (például a gótok). A pányvavetés mint harcolási mód a Kr. u. 2. és 6. század között széles körben elterjedt volt a nomád népeknél (szarmaták, alánok, hunok). A későbbiekben azonban nem figyelhető meg a kútfőkben ez a fegyver, csak a mongoloknál tünik fel újból a forrásokban a használata. Ennek ellenére azonban nem jelenthető ki egyértelmüen, hogy a 6. századtól a mongolokig terjedő időszakban a nomád népek ne használtak volna pányvát. Egyrészt fontos hangsúlyozni, hogy a pányva nemcsak fegyverként szolgált, hanem fontos eszköze volt a nomád népeknek a nagyállattartó pásztorkodásban. Ennél fogva kevés a valószínüsége, hogy például az avarok vagy a honfoglaló magyarok ne használták volna az állattartásukban. Másrészről a fogolyszerzésben is fontos eszköz lehetett. Az avarok esetében is utalnak arra a kútfők, hogy a szlávoktól rabszolgákat hurcoltak el, és például bizánci területekről is foglyokat szereztek. A későbbiek folyamán a magyarok, a besenyők és a kunok kapcsán is vannak adataink rabszolga-kereskedelemröl (POLGÁR 2006, 99-112). Feltételezhető, hogy ezek a népek is használhatták ezt az eszközt is a foglyok elfogásakor. Úgy tűnik, ekkorra már a bizánci hadseregben is általános fegyverré vált a pányva, ugyanis a használatáról Bölcs Leó is megemlékezik a bizánci hadsereg fegyverzete kapcsán (Bölcs Leó V. 3., VI. 10. vö. DENNIS 2010, 77, 89). A forrásokban az avarok fegyverzetében szerepel a távolharci fegyver, a parittya, melynek a használata a bizánci-avar és a frank-avar háborúk időszakában is feltünik. Alkalmazása széles körben elterjedt volt Európában már a római kortól kezdve. Valószínűleg az avarok vagy a bizánciaktól, vagy pedig más európai népektől vehették át a használatát ennek az eszköznek.

Egyes fegyvereknél megfigyelhető, hogy gyakorlati jelentőségük mellett szimbolikus jelentésük is lehetett a vizsgált nomád népek körében. Az íjak esetében a hunoknál egyértelmüen kitünik az írott forrásokból, hogy az uralkodói hatalom szimbólumai lehettek, amit a régészeti adatok is alátámasztanak. Az avarok esetében is feltételezhető, bár az írott forrásokban nem érhető tetten, hogy az íjnak a harcászatbeli szerepével párhuzamosan szimbolikus jelentősége is lehetett. Azonban csak a kunbábonyi leletből következtethetünk erre. Az íj mellett a kard esetében is feltételezhető, hogy szakrális szerepe lehetett ezen nomád népek körében. A hunoknál Attila kardjának Iordanes munkájában megőrződött mitikus története alapján egyértelműen megállapítható, 
hogy ez a fegyver az uralkodói hatalom egyik legelőkelőbb szimbólumának számított, amely legitimizálta viselőjének a hatalmát, és biztosította az uralma kontinuitását. A kútfőkben az avaroknál is megfigyelhető a kard kultikus szerepe, az 579/580. évi bizánciavar szerződéskötés leírásából kiderül, hogy Baján avar szokás szerint a kivont kardja előtt esküdött meg. Emellett egy az avarokra vonatkozóan bizonyos fokig kétséges forrásból arra következtethetünk, hogy a nomád népek körében széles körben elterjed szokás, a kard kultikus tisztelete és a kardnak bemutatott áldozás szokása az avaroknál is esetleg jelen lehetett.

A hadjáratokra, csatákra történő felkészülésnek több elemét lehet megfigyelni a hunoknál és az avaroknál is. Fontos szempont volt a nomád népek esetében is a különböző taktikai elemek begyakorlása. Erre vonatkozóan az avaroknál egyértelmű utalást találunk arra, hogy vadászat alkalmával (is) gyakorolhattak a hadjáratokra. A hunok esetében viszont csak nomád analógiák alapján következtethetünk arra, hogy az auktorok által megemlített hun vadászatok nem csak a vad elejtésére szolgálhattak.

A csaták közbeni taktikai elemek sikeres végrehajtása érdekében a gyakorlás mellett fontos szempont volt a fegyelem betartása is. Bár a hunok esetében nem találunk erre vonatkozóan utalást a kútfőkben, és az avarokról is csak általános információt kapunk ebben a témában Maurikiostól, valószínüleg mindkét nomád nép nagy hangsúlyt fektethetett a fegyelem betartására, mint erre vonatkozóan más nomád (és nem nomád) népröl vannak adataink.

Fontos feladat volt egy-egy hadjárat megindítása előtt és a hadjáratok közben is tájékozódni a kiszemelt területek földrajzi helyzetéről és népességéről stb., valamint az ellenfél hadseregének felépítéséről, létszámáról, hadmozdulatairól, ennek ellenére a hunok és az avarok esetében csak kevés adatból következtethetünk erre. A hunokról csak közvetett adatokból feltételezhetjük egy-egy sikeres hadjárat esetében, hogy pontos információik lehettek a hadjáratukra kiszemelt területekről. Maurikios az avarok kapcsán ebben a témában is csak általánosságban nyilatkozik, miszerint „ügyesen kilesik” a megfelelő helyzetet, és azt ki is használják. Azonban más forrásokból kiderül, hogy az avarok a számukra ismeretlen területeken jól tájékozódni képes embereket, „útikalauzokat” alkalmaztak, akik a kívánt célpontig kalauzolták seregüket. Emellett az avaroknál az a jelenség is megfigyelhető, hogy a felderítők az ellenfél hadseregéből „nyelveket” fogtak, hogy információkat szerezzenek tőlük.

Gyakori jelenség a nomád népeknél, hogy a hadjáratok indításakor és közvetlenül a csatákat megelőzően jósoltattak annak érdekében, hogy kiderüljön: ki kerül ki győztesen az 
összecsapásból. Ezt a jelenséget azonban csak a hunok esetében figyelhetjük meg, akik béljóslást és csontból történő jóslást alkalmaztak Iordanes szerint a mauriacumi csatát megelőzően. Ez utóbbi szokás általános jelenségnek tekinthető az eurázsiai steppén. A béljóslás viszont nem jellemző a nomád népeknél, ám a Római Birodalom területén széles körben elterjedt hagyománynak tekinthető, jóllehet a 4. századra a rómaiaknál is visszaszorult ez a tradíció. Bár Maenchen-Helfen elfogadja a hunok esetében ezt a jóslási módot, és egy másik auktor (Prosper Tiro) munkájában található bizonytalan adattal próbálja alátámasztani elméletét, ennek ellenére az a lehetőség is felmerülhet, hogy mindez csak Iordanes fikciója lehetett.

A nomád hadsereg vonulásában komoly nehézséget okozhatott a folyókon történő átkelés. A hunok esetében csak néhány adatot találunk az írott forrásokban arra vonatkozólag, hogy az időjárás adottságait esetenként kihasználva a befagyott folyón keltek át, vagy pedig fatörzsböl készült/kivájt csónakokat és tutajokat használtak az átkelésre. Az avaroknál azonban sokkal komplexebb kép bontakozik ki ebben a témában. Kisebb folyók esetében egyszerüen átúsztattak a lovaikkal, vagy pedig bevárva a telet a befagyott vizen keltek át. Emellett az alávetett népeikkel (szlávok) vagy pedig szövetségeseikkel (langobardok és bizánciak) is építtettek átkelésre alkalmas eszközöket. Míg az alávetett szlávok egyszerü farönkből kivájt csónakokat biztosítottak „uraiknak”, addig a langobardok hajóépítőkkel, a bizánciak pedig hídépítőkkel és hajókkal segítették a velük szövetséges avarokat. Saját maguk is készíthettek e célra megfelelő alkalmatosságokat. A források adataiból azonban nem lehet megállapítani, hogy a „szkíta módra” épített hídnak milyen sajátosságai voltak, és miben különbözött a bizánciakétól.

A hadsereg utánpótlás-problémáját többféle módon oldották meg a hunok és az avarok. Egyrészt biztosíthatták maguk számára az élelmet zsákmányolásból és esetleg vadászatból. Másrészről számos dolgot kénytelenek voltak magukkal vinni a hadjáratokra, amelyekre a kútfők mindkét nép esetében utalnak a szekereik említésével. Mindkét nomád nép esetében tetten érhető a forrásokban, hogy a hadjáratokra jelentős számú tartalék lóállománnyal indultak. Továbbá az avarok kapcsán a forrásokban megfigyelhető, hogy békekötések és szövetségkötések értelmében is hozzájutottak olyan dolgokhoz, melyek biztosították számukra az utánpótlást.

A csaták közbeni jelenségek közül a harc megkezdésének időpontjáról csak az avarok esetében vannak adataink, miszerint egyrészt megfigyelhető náluk a hirtelen, rajtaütésszerü, gyakran éjszakára időzített támadás. Másrészről arra is találunk adatot a 
kútfökben, hogy középkori szokás szerint az avarok is az ellenféllel előre megegyeztek a csata időpontjában.

Míg a hadrenddel kapcsolatban a hunok esetében csak egy adatunk van, addig az avarok esetében több információ áll a rendelkezésünkre. Iordanes a klasszikus csatrendre történő felállásról szolgáltat adatot, miszerint a hunok a centrumban helyezkedtek, a jobb és a bal szárnyon pedig a segédnépek foglaltak helyet. Az avaroknál viszont Maurikios azt hangsúlyozza, hogy a „bizánci mintájú” hármas felosztással (jobb és bal szárny, középvéd) szemben az avarok több különböző ezredbe, egységbe tömörülnek, mely felállásukkor egységes, egyetlen csatarendnek tünik. Végeredményben ez az egységesnek látszó hadrend bomlik fel a támadásuk során több részre, melyek különböző taktikai utasításokat hajtanak végre. Ezt a jelenséget több auktor (főként Theophylaktos) munkájában található információ megerősíti. Bár ezekben a csataleírásokban nem találunk pontos adatot az avar hadsereg harcmodorára vonatkozólag, azonban a hadrendjükből egyértelmüen következtethetünk arra, hogy könnyüfegyverzetü lovasságra jellemző taktikát alkalmaztak. A hun hadseregnek is az avarokhoz hasonló, több egységből felálló hadrendje lehetett a színlelt megfutamodás taktikája kivitelezésekor, melyre több forrás is utal.

Mindkét nép hadseregének létszámára számos forrás utal, azonban a középkori forrásokban fellelhető létszámadatok eléggé megbízhatatlanok, így messzemenő következtetéseket nem lehet levonni sem a hun, sem az avar hadsereg létszámára. Ami azonban kitünik a fent nevezett forrásokból, hogy a hunok és az avarok hadi szerveződése is tízes rendszeren alapult, ahogy más steppei török és mongol nyelvü népek, valamint más kultúrkörböl származó (például bizánciak) népek esetében is a hadsereg századokból, ezredekből, tízezredekből épült fel. A hunoknál érdemes egy forrást kiemelni e témában. A kései keletkezésű skandináv Hervar és Heidrik sagából (Hervarar saga ok Heiðreks) egyértelműen kitünik, hogy a hun hadsereg századokból, ezredekből és tízezredekből épül fel. A forrás megemlékezik ezen egységek létszámáról is, amiből kiderül, hogy a század, ezred és a tízezred több harcost foglalt magába, mint száz vagy ezer vagy tízezer fö. Ezt az adatot azért érdemes kiemelnünk, mert eddigi ismereteink szerint más népek tümenjeinek harcoslétszáma inkább kevesebb 10 ezer főnél.

A hun hadseregben a katonai jeladások közül hangjelek és a félhangjelek figyelhetők meg az írott forrásokban, míg az avar hadseregben a hunoknál említett jelek mellett némajelekre vonatkozó adatokat is találunk. A hangjelekre csak néhány forrásból következtethetünk, amelyekből kiderül, hogy a hunok és az avarok csata és ostrom közben kiabáltak, lármáztak. Feltételezhetően ezek között lehetett olyan kiáltás, mely a nomád 
csapategységek közötti katonai jelzések továbbítására szolgálhatott. Míg a hunoknál a félhangjelek közül a kürtöket csak megemlítik a források a mauriacumi csata kapcsán, addig az avarok kürtjeiről számos adatot találunk. Az auktorok híradásából kitűnik, hogy a kürt egyrészt kagáni harci jelvényként szolgált, valamint a magasra emelt vagy a megszólaltatott harci kürt a hadba vonulást jelképezte az avaroknál. Továbbá néhány adatból egyértelmüen kitünik, hogy a kürtöket harc közben is használták, melyek ez esetben szolgálhattak a harc közbeni kommunikációra a különböző egységek között. Az avaroknál a némajelekre is találunk példát, melyek közé a zászlós lándzsa és a korbács vagy ostor sorolható. Továbbá feltételezhető, az auktorok által megemlített dobok erre a célra is szolgálhattak. A hunok esetében is feltételezhető ezeknek az eszközök a szerepe, bár a forrásokban erre vonatkozó adatot nem találunk. Az ostorra vagy korbácsra esetleg régészeti adat is utalhat, feltételezhető, hogy a nagyszéksósi kincslelet darabjai között ostor- vagy korbácsnyél díszítésére szolgáló aranylemezek is lehettek (KÜRTI 2007, 260).

A pszichológiai hadviselés jelensége mindkét nomád nép esetében megfigyelhető többféle formában. A hunok és avarok esetében is több forrás emlékezik meg arról, hogy félelmetes hangokat, zajokat hallattak, valamint kürtök és esetleg dobok hangjával próbálták megrémíteni az ellenséget. A pszichológiai hadviselés egyik formájaként értelmezhető az is, hogy nagyobb létszámúnak próbálják feltüntetni a hadseregüket az ellenség szemében, mint amekkora valójában. Ezt például a hadsereghez tartozó nagy létszámú tartalék lovakkal érhették el. Mindkét nomád nép esetében megfigyelhető, hogy a győzelem érdekében különböző varázslási praktikákhoz is folyamodtak. A hunok ezzel a mágikus cselekedettel azt akarták elérni, hogy seregük jóval nagyobbnak látszódjon, mint amekkora valójában. Az avarok pedig a varázslással különféle kísértetalakokat jelenítettek meg, amelyeknek a segítségével diadalt arattak a frankok felett.

A hadjáratok alkalmával hunok és az avarok is gondoskodtak a hadseregük táborának védelméről. A hunok esetében egyértelmüen tetten érhető ez a jelenség a mauriacumi csata alkalmával, amikor is Attila táborának a védelmét szekérsánc látta el. Az avarok esetében csak az alávetett szláv segédnépük esetében figyelhető meg a tábor szekérsánccal történő védelme. Emellett feltételezhető, hogy a szükséges dolgokat (például élelem, fegyverek, sátrak és az ostromeszközök egyes részei) szekereken magával szállító, hadjáratra vonuló avar sereg a tábora kialakításánál a szekereket felhasználhatta annak védelmére. Maurikios ezzel szemben azt hangsúlyozza, hogy az avarok őrszemek állításával oldják meg a táboruk védelmét. 
A hadsereg egységei közül a hadjáratra vonuló sereg biztosítását az elővéd látta el, mely legtöbbször az alávetett segédnépekből verbuválódott. A hunok esetében a mauriacumi csata kapcsán következtethetünk erre, ahol a gepidák látták el ezt a szerepet. Az avaroknál pedig a szlávok töltötték be ezt a funkciót.

A hunok és az avarok harcmodorának és életmódjának megítélése kapcsán érdekes jelenséget figyelhetünk meg az írott forrásokban. Mindkét népnél érzékelhető - ahogy más „barbár” népek esetében is -, hogy az auktorok többsége igyekszik negatív színben feltüntetni szokásaikat, harcmodorukat, külső megjelenésüket. A hunok és avarok esetében is megemlékeznek arról, hogy hitszegők, haszonlesők, „komiszok és kétszínűek”, kegyetlenek, és ocsmány a megjelenésük. Azonban csak a hunok esetében figyelhető meg a vizsgált két nomád nép közül a könnyüfegyverzetű lovasíjász harcmodoruk eröteljes hangsúlyozása. Több forrás emlékezik meg arról, és hangsúlyozza - legtöbbször erösen túlzó módon -, mennyire kiváló lovasok, és mennyire kitűnően bánnak az íjjal, nyíllal. A hunok általános jellemzésénél is elsősorban az íj és a nyíl használatát emelik ki a kútfők. Valamint a kiváló lovaglótudásukkal párhuzamosan több auktor is hangsúlyozza, hogy képtelenek a gyalogos közlekedésre és harcmodorra. Ezzel szemben az avarok esetében teljesen más kép bontakozik ki az írott források adataiból. Maurikios ugyanennél a nomád népnél megemlíti - toposzt használva -, hogy gyalogosan nem képesek harcolni, mivel járni sem tudnak, de a hunoknál több forrás által is kiemelt kiváló lovaglótudás, kentaurhoz történő hasonlítás, az íj és a nyíl használatának erőteljes hangsúlyozása nem figyelhető meg az avaroknál. Maurikios is gyakorlatilag az íjat és a lándzsát egyenrangú fegyvernek tartja az avarok fegyverei közül, amellett, hogy megemlíti, nagy gondot fordítanak a lóháton történő íjazás elsajátítására. Ezzel párhuzamosan azonban a hadászatban jártas császár részletesen ismerteti ezen nomád nép könnyüfegyverzetű lovasságának haditaktikáját. Lindner szó szerint vette a források adatait, és úgy vélte, hogy a hunok sokkal inkább lovasoknak tarthatók, mint az avarok. Valamint arra a következtetésre jutott, a 6. század végi avar támadásokról szóló leírások azt mutatják, hogy a lovasságuk nem jelentős, és nem mutatható ki a könnyüfegyverzetű lovasíjászok nyoma. Véleménye szerint az avarok jelentősebb csatái gyalogsági csaták voltak (LINDNER 1981, 17). A források adataiból kibontakozó kép azonban valószínűleg nem azzal magyarázható, hogy az avar hadseregnek nem volt könnyüfegyverzetü lovassága. A Volgát a 370-es években átlépő hunok jelentős támadást intéztek a Római Birodalom és a birodalmat körülvevő „,barbár” népek ellen. A hun támadások jelentős hatást gyakoroltak Európa etnikai képének átalakulására. Korábban a szkíták és a szarmaták harcmodorával már találkoztak a 
letelepült népek, és ezeket a tapasztalataikat le is jegyezték, melyeket (főként Hérodotos híradását) fel is használták a későbbi nomádok - köztük a hunok - jellemzésére is. Azonban ezek az iráni nyelvű nomád népek nem gyakorolhattak akkora hatást a letelepült birodalmakra, mint később a hunok. A mindent elsöprő hun támadás gyakorlatilag sokkhatásként érhette a rómaiakat, amit erősen túlzó módon le is jegyeztek. A hunok esetében a saját hadseregükben, harcmodorukban idegen, ismeretlen elemeket hangsúlyozták, emelték ki. A délorosz steppén a 6. század második felében megjelenő avarok esetében viszont már nem volt ennyire meglepö, idegen a nomád könnyüfegyverzetü lovasnomád taktika a letelepült birodalmak számára. Ugyanis az 5. század közepétől megfigyelhető például, hogy a bizánci harcmodorra jelentős hatást gyakoroltak a birodalom határainál megjelenő nomád népek. Nemcsak a taktikai elemeket vették át, hanem a bizánci seregben is megjelentek nomád segédnépek. Prokopiosnál is láthatjuk, hogy a bizánci sereg I. Justinianus császár uralkodása idején is mennyire vegyes etnikumú volt. Több más nép között megtalálhatók a bizánci seregben különböző nomád népek is, például például bulgárok, szabirok, kutrigurok (TEALL 1965, 294-322; KOLIAS 1988, 28-30; KAEGI 1990, 76). Tehát az avarok „tetteit” lejegyző auktorok számára nem az volt a lényeges szempont, hogy a könnyüfegyverzetü lovasíjász harcmodorukat hangsúlyozzák, hiszen erről már egyébként jelentős tapasztalataik voltak, és nem volt ismeretlen a számukra. Mindkét nomád nép harcmodora kapcsán megfigyelhetők a forrásokban az ék alakban történő támadás, a színlelt megfutamodás, a rajtaütésszerü, lesből történő támadás és a bekerítés is, mely taktikai elemek nagyon elterjedtek voltak az eurázsiai steppe nomádjai körében. A hunok és avarok kapcsán is egyértelmüen megállapítható, hogy az ék alakban történő támadás esetében szétszóródó, több egységből álló, laza csatarendről van szó. Emellett hangsúlyozandó, hogy míg a hunok esetében több forrás kisebb utalásaiból együtt vázolhatók fel a fent nevezett taktikai elemek, addig az avarok esetében egyetlen forrás, Maurikios hadászati munkája említi meg ezeket együttesen. A hadászatban jártas szerző írja le először részletesen a színlelt megfutamodás taktikáját. A korábbi források nem ábrázolták ennyire részletesen ezt a taktikát. Ennek a taktikai elemnek a lesben állás, bekerítés eleme szintén az avaroknál tünik fel elöször. Emellett azonban hangsúlyozandó, hogy a bekerítés nem kizárólag a színlelt megfutamodáshoz kapcsolódik, más kontextusban is megfigyelhető a nomádok hadi repertoárjában, és ezen belül az avarokéban is. A hunok esetében a hátrafelé nyilazás is a színlelt megfutamodás taktikai elemeként tűnik fel a kútfőkben. Az avarok esetében viszont egyáltalán nem figyelhető meg az írott forrásokban, viszont egy az avarokkal 
azonosítható ábrázoláson szerepel ez a nyilazási mód a frank-avar háborúk időszakából. A könnyüfegyverzetü lovasság egyik jellegzetes, nem csak a nomád népekre jellemző hadifogása, a felperzselt föld taktikája szintén feltételezhető az avaroknál. A kutatók egy része Nagy Károly 791-es hadjárata kapcsán úgy véli, hogy az avarok ezt a taktikát vetették be a frankok ellen, és ezzel kényszeríttették ki a frank sereg visszavonulását.

A könnyüfegyverzetü lovasság mellett azonban mindkét nomád nép esetében feltételezhető nehézfegyverzetü lovasság is. Az írott források adataiból úgy tünik, hogy a hunoknál valószínüleg kisebb jelentősége lehetett ennek a csapategységnek. Feltételezhetően a nehézfegyverzetű lovasságuk egyrészt keletről, Belső-Ázsiából magukkal hozott elemekből és/vagy a délorosz steppén meghódoltatott alánokból tevődhetett össze. Az avarok esetében azonban úgy tünik, hogy a bizánci-avar háborúk időszakában jelentősebb szerepük lehetett ezeknek a nehézfegyverzetü lovasosztagoknak. Az avar nehézfegyverzetű lovasságnak fő támadófegyverzete a hosszú döfőlándzsa volt, és esetleg a hosszú, kétélü kard. Valamint a harcos páncélozottsága mellett feltételezhető, hogy a lovát is ellátták vértezettel. A későbbiek folyamán, a frank-avar háborúk időszakában valószínűleg újból nagyobb jelentősége lehetett a nehézfegyverzetű lovasságnak, bár korántsem akkora, mint amilyen a Bizánci Birodalom elleni hadjáratok idején. Ebben a kései időszakban megjelenhettek frank típusú fegyverek is a felszerelésükben (például páncél).

Egy-egy csata esetében feltételezhető, hogy a könnyüfegyverzetű lovasíjászok különböző taktikai elemeik bevetésével felbomlasztották és szétzilálták az ellenfél hadrendjét, és valószínüleg ekkor vethették be a nehézfegyverzetü lovas egységeiket, melyek végső csapást mértek az ellenfélre.

Több nomád népnél megfigyelhető, hogy rendelkezett a hadseregük saját népükből verbuvált gyalogsággal. A hunoknál és az avaroknál ez a jelenség nem támasztható alá írott forrásokkal. Mindkét nép esetében a hadseregük gyalogsága alávetett segédnépekből szerveződhetett: a hunoknál germán népek, az avaroknál pedig szlávok és gepidák alkothatták e nomád népek seregének gyalogságát (is). A hunok és az avarok segédnépei között a gyalogság kapcsán a fentebb felsorolt népek mellett még nomád népek is jelen voltak. A hunok esetében alánok, az avarok kapcsán kutrigurok, bulgárok feltételezhetők elsősorban. Az avarok hadseregében azonban nem zárhatók ki teljesen szabir, utigur, langobard elemek sem. 
A nomád birodalmak uralkodóinak védelmét biztosító testőrség a hunok esetében Attila kapcsán egyértelműen tetten érhető a forrásokban. Az avar kagán testőrségére azonban csak néhány forrás közvetett utalásaiból következtethetünk.

Ahhoz, hogy a hunok és az avarok a Római Birodalommal/Bizánci Birodalommal szembeni támadásaik során sikereket érjenek el, elengedetlenül fontos volt az erődítmények elleni ostromtechnika alkalmazása is. Megállapítható, hogy az avarok ostromtechnikájára sokkal több adat áll rendelkezésünkre, mint a hunokéra. A mindkét nomád nép támadásai során használt ostromgépek építését nemcsak az alávetett segédnépek és hadifoglyok végezhették, hanem maguk a nomádok is képesek voltak ilyen szerkezeteket előállítani. Némely típus építési technikáját átvehették európai birodalmaktól. Erre jó példa, hogy a hunok a Római Birodalomtól, az avarok pedig a Bizánci Birodalomtól tanulhatták el a torziós szerkezetü hajítógépek építési elvét. Egyes ostromgépfajtákat azonban keletről hozhattak magukkal a nomád népek. Feltételezhető, hogy az avarok a Kínában feltalált, egyszerübb szerkezetủ kőhajítógép építésének a tudását keletről hozhatták magukkal. A nomád népek azonban nemcsak képesek lehettek önállóan elkészíteni ezeket az ostromgépeket, hanem újításokat is be tudtak vezetni az ostromtechnika terén. Jól példázza ezt Prokopoios leírása, miszerint a szabirok olyan faltörőkos-típust építettek, mely mind a bizánciaknál, mind a perzsáknál teljesen ismeretlen volt. A hunok ostromtechnikája kapcsán megfigyelhető, egyszerü ostromtoronyszerü építmény is saját tervezésünek tünik, mindenesetre szerkezetileg nagyon különbözik a rómaiak ostromtornyaitól.

Összegezve a leírtakat megállapítható, hogy nem állja meg a helyét az az elképzelés, miszerint a könnyüfegyverzetü lovasság volt a kizárólagos a hunok és az avarok hadi repertoárjában. Az avaroknál viszont az sem fogadható el, hogy harcmodorukból kiszorult volna a könnyüfegyverzetű lovasság. Mindkét nomád nép hadi repertoárja esetében megfigyelhető a könnyüfegyverzetü és a nehézfegyverzetü lovasság, a gyalogság és az ostromtechnika is. Az, hogy melyik hadi egység és ezzel párhuzamosan mely taktikai elemek kerültek túlsúlyba, változó a hunoknál és az avaroknál. Hadászati szempontból kiemelendő az avarok harcmodoráról (is) megemlékező Maurikios Stratégikon című munkája. A szerző az avarok kapcsán a fegyverzetük felsorolása és a csaták közben alkalmazott taktikai elemek leírása mellett többnyire általános, más nomád népek harcászatára is alkalmazható információkat szolgáltat. Ezeket az általános, toposzokkal teli adatokat azonban jól kiegészítik (némely esetben cáfolják) más auktorok információi. 


\section{Felhasznált irodalom}

\section{1. Források}

Agathias =Agathiae Myrinaei. Historiarum libri quinque. Rec. Keydell, R. [Corpus Fontium Historiae Byzantinae 2.] Berolini 1967.

Agathias. The Histories. Trans. Frendo, J. D. [Corpus Fontium Historiae Byzantinae 2.A] Berlin-New York 1975.

ALCUIN $=$ Glossar A I. 231-233.

Alemany $2000=$ Alemany, A.: Sources on the Alans. A Critical Compilation. [Handbook of Oriental Studies. Section 8. Central Asia 5.] Leiden-Boston-Köln 2000.

AMMIANUS MARCELLINUS = Ammiani Marcellini. Rerum gestarum libri qui supersunt II.

Ed. Seyfarth, W. [Bibliotheca Scriptorum Graecorum et Romanorum Teubneriana] Leipzig 1978.

Ammianus Marcellinus. Róma története. Ford. Szepesy Gy. Budapest 1993.

Anna Komnena $=$ The Alexiad of Anna Comnena. Trans. Sewter, E. R. A. Harmondsworth 1979.

ANONYMUS = The Anonymus Byzantine Treatise on Strategy. In: Three Byzantine military Treatises. Text, Trans. and Notes by Dennis, G. T. [Corpus Fontium Historiae Byzantinae 25.] Washington 1985, 1-136.

ARriAnOs = Flavii Arriani quae exstant omnia 1-2. Ed. Roos, A. G. [Bibliotheca Scriptorum Graecorum et Romanorum Teubneriana] Lipsiae 1967-1968.

AStERIOS $=$ S. Patris nostri Asterii Amaseae episcopi. Ed. Combefis, F. [Graecolatinorum patrum bibliothecae novum auctarium] Parisiis 1648.

Aurelius ViCtor $=$ Sexti Aurelii Victoris Liber de Caesaribus. Praecedunt Origo Gentis Romanae et Liber de Viris Illustribus Urbis Romae subsequitur Epitome de Caesaribus. Rec. Pichlmayr, Fr. [Bibliotheca Scriptorum Graecorum et Romanorum Teubneriana] Leipzig 1970.

BERTA 2004 = Berta Á.: Szavaimat jól halljátok ... A türk és ujgur rovásírásos emlékek kritikai kiadása. Szeged 2004.

BÖLCS LEÓ = The Taktika of Leo VI. Trans. Dennis G. [Corpus Fontium Historiae Byzantinatinae 49.] Dumbarton-Washington 2010.

CAESAR = A gall háború. Julius Caesar. Ford. Szepessy T. Szeged 1994. 
CHRONICON PASCHALE = Chronicon Paschale. In: Glossar B I. 33-38.

Claudianus $=$ Claudian's in Rufinum. Ed. Levy, H. L. [Philological Monograps of the Americn Philological Association 30.] Princeton 1971.

Claudius Claudianus versei. Ford. Mezei B. Budapest 1988.

Clemens AleXAndrinus, Protrepticus $=$ Clemens Alexandrinus. Protrepticus und Paedagogus. Hrsg. Treu, U. [Die Griechischen Christlichen Schriftsteller der Ersten Jahrhunderte] Berlin 1972.

CORIPPUS = Corippe. Flavius Cresconius Corippus: Éloge sw l'empereur Justin II. Texte établi et traduit par Antes, S. [Collection "Budé"] Paris 1981.

EPITHAPIUM GEROLDI $=$ Monumenta Germaniae Historica. Scriptores rerum

Germanicarum in usum scholarum ex Monumentis Germaniae Historicis separatim editi, Poetae Latini medii aevi I. [Poetae Latini aevi Carolini I.] Ed. Duemmler, E. Berolini 1881, 114.

EPHRAIM = Glossar B I. 41 .

EuAgRIOS $=A$ IX. századi avar történelem görög forrásai. Szerk. Olajos T. [Szegedi Középkortörténeti Könyvtár 16.] Szeged 2001, 124.

GeÓRgIOs PisidÉS = Giorgo Di Pisida Poemi. Ed. Pertusi, A. Ettal 1960.

GERHARD = Catalogus fontium Historiae Hungaricae III. Collegit, revocait etc. Gombos, F. A., Budapestini, 1937-1938, 2615-2617.

GLOSSAR A = Glossar zur frühmittelalterlichen Geschichte im östlichen Europa. Hrsg. Ferluga, J. - Hellmann, M. - Ludat, H. - Zernack, K. Serie A. Lateinische Namen bis 900. Red. Wojtecki, D., Bd. I., Wiesbaden, 1973-1975.

GLOSSAR B = Glossar zur frühmittelalterlichen Geschichte im östlichen Europa. Hrsg: Ferluga, J., Hellmann, M. - Ludat, H. - Zernack, K. Serie B. Griechische Namen bis 1025. Red. Fourlas, A. A. - Katzanakis, A. A. Bd. I. Wiesbaden 1988.

GregOrIUS TURONENSIS = Gregorii Episcopi Turonensis. Historiarum libri decem I-V .

Ed. Buchner, R. [Ausgewählte Quellen zur Deutschen Geschichte des Mittelalters] Berlin 1967.

Tours-i Gergely. Korunk története. A frankok története. Ford. Mezei M. - Adamik T. Pozsony 2010.

GYÖRFFY 1965 = Györffy Gy. (közreadja): Napkelet felfedezése. Julianus, Plano Carpini és Rubruk úti feljegyzései. Budapest 1965.

HÉrodotos $=$ Herodoti. Historiae V-IX. Ed. Rosén, H. B. [Bibliotheca Scriptorum Graecorum et Romanorum Teubneriana] Stutgardiae 1997. 
Hérodotosz. A görög-perzsa háború. Ford. Muraközi Gy. Budapest 2000.

HIERONYMUS $=$ Saint Jérôme. Letters III-IV. Texte établi et traduit par Labourt, J. Paris 1953.

Szent Jeromos. Levelek. Ford. Adamik T. - Puskely M. - Takács L. Budapest 2005. $\mathrm{HKIF}=A$ honfoglalás korának irott forrásai. Szerk. Kristó Gy. [Szegedi Középkortörténeti Könyvtár 7.] Szeged 1995.

HoMÉros = Homérosz. Iliász. Odüszeia. Homéroszi költemények. Ford. Devecseri G. Budapest 1967.

IORDANES, Getica = Иордан о происхождении и деяниях гетов. Вступительная статья, перевод, комментарий Скржинской, Е. Ч. Москва 1960.

Iordanes. Getica. Közreadja Kiss M. Budapest 2005.

IORDANES, Romana = Iordanis Romana et Getica. In: Monumenta Germaniae Historica. Auctorum Antiquissimorum 5. Rec. Mommsen, T. Berolini 1961, ${ }^{2} 1-52$.

JOSEPHUS FlaviUS $=$ Josephus in nine volumes. The Jewish War 3. Trans. Thackeray, H. ST. J. London 1957.

Josephus Flavius. A zsidó háború. Ford. Révay J. Budapest 1999. ${ }^{6}$

KAROLus Magnus, Capitulare = Monumenta Germaniae Historica. Scriptores rerum Germanicarum in usum scholarum ex Monumentis Germaniae Historicis separatim editi, Legum sectio II. 1. (Capitularia regum Francorum I.) Ed. Boretius, A., Hannoverae 1883, 123.

KMOSKÓ 2000 = Kmoskó M.: Mohamedán írók a steppe népeiröl. Földrajzi irodalom I/2.

Szerk. Zimony I. [Magyar Östörténeti Könyvtár 13.] Budapest 2000.

KMOSKÓ 2004 = Kmoskó M.: Szír irók a steppe népeiről. Szerk. Felföldi Sz. [Magyar Östörténeti Könyvtár 20.] Budapest 2004.

KONSTANTINOS AKROPOLITÉS = Glossar A I. 85-87.

KÓNSTANTINOS PORPHYROGENNÉTOS $=$ Bíborbaszületett Konstantín. A birodalom kormányzása. Ford. Moravcsik Gy. Budapest $2003 .^{2}$

LIU 1958 = Liu Mau-tsai: Die chinesischen Nachrichten zur Geschichte der Ost-Türken (T'u-küe). [Göttinger Asiatische Forschungen 10.] Wiesbaden 1958.

MALALAS = Ioannis Malalae. Chronographia . Rec. Thurn, I. [Corpus Fontium Historiae Byzantinae 35.] Berlin 2000.

The Chronicle of John Malalas. Trans. Jeffreys, E. - Jeffreys, M. - Scott, R. [Byzantina Australiensia 4.] Melborne 1986.

MANASSES $=$ Glossar B I. 87-88. 
MARCo Polo = Marco Polo utazásai. Ford. Vajda E. Budapest $1984 .^{2}$

MAURIKIOS = Mauricii Strategicon - Das Strategicon des Maurikios. Ed. Dennis, G. T.,

Germanice vertit Gamillscheg, E. [Corpus Fontium Historiae Byzantinae 17.] Vindobonae 1981.

$\mathrm{MEH}=$ A magyarok elödeiről és a honfoglalásról. Kortársak és krónikások híradásai. Szerk. Györffy Gy. Budapest 2002. ${ }^{5}$

MENANDRos ProtéKTÓR = The History of Menander the Guardsman. Trans. Blockley, R.

C. [ARCA 17.] Ottawa 1985.

Glossar B I. 106-112.

Merobadeus = Flavius Merobaudes. Ed., Trans. Clover, F. M. [Transactions of the American Philosophical Society 61.] Philadelphia 1971.

Olajos T.: Merobaudes müvei. Antik Tanulmányok 13 (1966), 172-188.

Miracula S. DEMETRII = Les plus anciens recueils des miracles de Saint Démétrius. Le texte par Lemerle, P. Éditions du Centre national de la recherche scientifique. Paris 1979.

NiCOLAI I. PAPAE Epistolae $=$ Nicolaus capitulis 106 ad Bulgarorum consulta respondet. In: Monumenta Germaniae Historica. Epistolae Karolini Aevi IV. Ed. Dümmler, E. Perels, E. München 1978, 568-600.

NiKEPHOROS CALLISTOS XANTHOPULOS = Glossar B I. 135-136.

NikePhOROS OuRANOS $=$ The Taktika of Nikephoros Ouranos. In: Sowing the Dragon's teeth: Byzantine Warfare in the Tenth Century. Ed. McGeer, E. Washington 1995, 79-170.

OlAJos 2001 = Olajos T. (ford.): A IX. századi avar történelem görög forrásai. [Szegedi Középkortörténeti Könyvtár 16.] Szeged 2001.

OLYMPIODOROS = Olympiodorus. In: BLOCKLEY 1983, 152-221.

PaCAtus = Latini Pacati Drepanii Panegyricus Theodosio Augusto Dictus. Altorphium 1750.

Pacatus Panegyric to the Emperor Theodosius. Trans. Nixon, C. E. V. [Translated Texts for Historians. Latin Series 2.] Liverpool 1987.

PAULuS Diaconus, Historia Langobardorum = Glossar A I. 246-247.

Paulus Diaconus. A langobardok története. Közreadja Galamb Gy. [Mediaevalia] Budapest 2012.

Paulus Diaconus, Historia Romana = Pauli Diaconi. Historia Romana . Ed. Crivellucci, A. [Fonti per la Storia d'Italia. Scittori 7.] Torino $1960 .^{2}$ 
PAULINUS AQILEIENSIS $=$ Monumenta Germaniae Historica. Scriptores rerum Germanicarum in usum scholarum ex Monumentis Germaniae Historicis separatim editi. Poetae Latini medii aevi I. [Poetae Latini Carolini I.] Red. Duemmler, E. Berolini 1881, 131-133.

PAUSANIAS = Pausaniae Graeciae descriptio I. Ed. Rocha-Pereira, M. H., [Bibliotheca Scriptorum Graecorum et Romanorum Teubneriana] 1973 Leipzig.

Pauszaniasz. Görögország leírása. Ford. Muraközi Gy. Budapest 2000.

PhILOSTORgIUS $=$ Philostorgius Kirchengeschichte. Mit dem Leben des Lucian von Antiochien und den Fragmenten eines Arianischen Historiographen. Hrsg. Bidez, J. Berlin 1972.

PLÓTINOS THESSALONIKEUS = Glossar B I. 139-140.

Pomponius Mela = Pomponius Mela. . Chorographia . Ed. Ranstrand, G. [Studia Graeca et Latina Gothoburgensia 28.] Göteborg 1971.

PRISKOS = Priscus. In: BLOCKLEY 1983, 222-401.

ProKopIos, De bello Vandalico = Procopius. History of the Wars. Books III. and IV. Vol. 2. Trans. Dewing, H. B. London 1953.

Prokopios, De bello Gothico = Procopius. History of the Wars. Books V., VI., VII. and VIII. Vol. 3-5. Trans. Dewing, H. B. London 1953-1954.

Pseudo Hegesippus = Hegesippi, qui dicitur Historiae. Ed. Ussani, V. [Corpus scriptorum ecclesiasticorum Latinorum 61.] New York $1960 .^{2}$

Quintilianus = Marcus Fabius Qintilianus. Szónoklattan. Szerk. Adamik T., Ford. Adamik T. - Csehy Z. - Gonda A. - Kopeczky R. - Krup J. - Polgár A. - Simon L. Z. - Tordai Z. Pozsony 2008.

$\mathrm{SHM}=$ The Secret History of the Mongols. A Mongolian Epic Chronicle of the Thirteenth Century I-II. Trans. Rachewiltz, I. Leiden-Boston 2006.

Sidonius, Carmina = Sidonius. Poems and letters. I. Trans. Anderson, W. B. [The Loebl Classical Library] London-Cambridge 1965.

SidOnIUS, Epistula = Sidonius. Poems and letters. II. Trans. Anderson, W. B. [The Loebl Classical Library] London-Cambridge 1965.

SOKRATES = Szókratész egyháztörténete. Ford. Baán I. Budapest 1984.

SOZOMENOS = Sozomenus. Kirchengeschichte. Hrsg. Bidez, J. Berlin 1960.

SUDA = Suidae Lexicon I-V. Ed. Adler, A. [Lexicographi Graeci 1.] Stuttgart 1967-1971.

SzÁDECZKY-KARDOSS 1979-1980 = Szádeczky-Kardoss S.: A bolgár történelem forrásai Asparuch elött I-II. Kézirat. Szeged 1979-1980. 
SzÁDECZKY-KARDOSS 1998 = Szádeczky-Kardoss S.: Az avar történelem forrásai 557-töl 806-ig. [Magyar Östörténeti Könyvtár 12.] Budapest 1998.

SZEMA-KIEN = A hunok legkorábbi története. Írta: Sima Qian. A Shi Ji 110. kötete. Ford.

Du Yaxiong - Horváth I. Peking 1997.

TACITUS $=$ Tacitus összes müvei. Ford. Borzsák I. Szeged 2001. ${ }^{3}$

THEODÓROS SYNKELlOS = Traduction et commentaire de l'homélie écrite probablement par Théodore le Syncelle sur le siège de Constantinople en 626. Makk, F. [Acta

Universitatis Szegediensis de Attila József Nominatae. Acta Antiqua et Archaeologica 19. Opuscula Byzantina 3.] Szeged 1975.

Glossar B. I. 55-68.

THEOPHANES = The Chronicle of Theophanes. Trans. Turtledove, H. Philadelphia 1982.

TheOPHYlaKtos SimoKattés = Theophylacti Simocattae. Historia. Ed. Boor, C. D. rev.

Wirth, P. Stutgardiae 1972.

The History of Theophylact Simocatta. Trans. Whitby, M. - Whitby, M. Oxford 1986.

Theophülaktosz Szimokattész. Világtörténelem. Ford. Olajos T. [Magyar Östörténeti Könyvtár 26.] Budapest 2012.

TOLKIEN 1960 = Tolkien, C. (trans.): Saga Heiđreks konungs ins vita. The Saga of King Heidrek the Wise. London 1960.

Vegetius $=$ Vegetius $=P$. Vegeti Renati. Digestorum artis Mulomedicinae libri. Ed. Lommatzsch, E. Lipsiae 1903.

Flavius Vegetius Renatus. A hadtudomány fogalma. Ford. Várady L. In: $A$ hadmüvészet ókori klasszikusai. Szerk. Hahn I. Budapest 1963.

VITA ANIANI = Incipit virtus Sancti Aniani episcopi quemadmodum civitatem Aurelianus suis orationibus a Chunus liberavit. In: Monumenta Germaniae Historica. Scriptorum rerum Merovingicarum 3. Passiones Vitaeque Sanctorum Aevi Merovingici Et Antiquiorum Aliquot. Ed. Krusch, B. Hannoverae 1896, 108-117.

WALTHARIUS = Waltharius, Ruodlieb, Märchenepen. Lateinische Epik des Mittelalters mit deutschen Versen. Hrsg. Langosch, K. Berlin 1956.

ZONARAS $=$ Glossar B I. 83-85.

Zosimos $=$ Zosimus. Rec. Bekkerei, I. [Corpus Scriptorum Historiae Byzantinae] Bonnae 1887.

Zosimos. Neue Geschichte. Hrsg. Rebenich, S. [Bibliothek der Griechischen Literatur 31.] Stuttgart 1990. 


\section{2. Szakirodalom}

AdAMIK-Mezei 2010 = Mezei M. - Adamik T. (ford.): Tours-i Gergely. Korunk története. A frankok története. Pozsony 2010.

AdAMIK-Puskely-TaKÁcs 2005 = Adamik T. - Puskely M. - Takács L. (ford.): Szent Jeromos. Levelek. Budapest 2005.

Albaum 1975 = Альбаум, Л. И.: Живопись Афрасиаба. Ташкент 1975.

Alemany $2000=$ Alemany, A.: Sources on the Alans. A Critical Compilation. [Handbook of Oriental Studies. Section 8. Central Asia 5.] Leiden-Boston-Köln 2000.

Allsen 1987 = Alsen, T. T.: Mongol Imperialism. The policies of the Grand Qan Möngke in China, Russia and the Islmaic Lands 1251-1259. Berkeley-Los AngelesLondon 1987.

ALFÖLDI 1932 = Alföldi A.: Leletek a hun korszakból és ethnikai szétválasztásuk. [Archaeologia Hungarica 9.] Budapest 1932.

Altheim 1962 = Altheim, F.: Geschichte der Hunnen IV. Die Europäischen Hunnen. Berlin 1962.

ANDrews $1999=$ Andrews, P. A.: Felt Tents and Pavilions. The Nomadic Tradition and its Interaction with Princely Tentage I-II. London 1999.

ANDERSON = Anderson, W. B. (trans): Sidonius. Poems and letters. I. [The Loebl Classical Library] London-Cambridge 1965.

ANKE 1998 = Anke, B.: Studien zur reiternomadischen Kultur des 4. bis 5. Jahrhunderts 1-2. [Beiträge zur Ur- und Frühgeschichte Mitteleuropas 8.] Weissbach 1998.

ANTES 1981 = Antes, S. (Texte établi et traduit): Corippe. Flavius Cresconius Corippus: Éloge sw l'empereur Justin II. [Collection "Budé"] Paris 1981.

ANTON 1989 = Anton, H. H.: Gregor Tours. In: LexMa 4. 1679-1681.

Austin 1979 = Austin, N. J. E.: Ammianus on Warfare. An Investigation into Ammianus' Military Knowledge. [Collection Latomus 165.] Bruxelles 1979.

Avenarius 1974 = Avenarius, A.: Die Awaren in Europa. Amsterdam-Bratislava 1974.

BABAJAROV-UMIROV-TASAgIL-NOVOZSENOV 2013 = Бабаяров, Г. - Умиров, К. Ташагыл, А. - Новоженов, В.А.: Западный Тюркский каганат: территория, административное устройство, племена, коммуникации, денежное обращение, 
монеты, источники. In: Западный Тюркский каганат. Атлас. Ред. Досымбаева, А. - Жолдасбеков, М. Астана 2013, 100-173.

BACHRACH 1971 = Bachrach, B. S.: The Feigned Retreat at Hastings. Mediaeval Studies 33 (1971), 344-347.

BACHRACH $1973=$ Bachrach, B. S.: A History of the Alans int the West From Their First Appearance in the Sources of Classical Antiquity through the Early Middle Ages. Minneapolis 1973.

BACHRACH 1984 = Bachrach, B. S.: A Picture of Avar-Frankish Warfare from a Carolingian Psalter of the Early Ninth Century in Light of the Strategicon. Archivum Eurasia Medii aevi 4 (1984), 5-28.

BACHRACH 1994 = Bachrach, B. S.: The Hun Army at the Battle of Chalons (451). An Essay in Military Demography. In: Ethnogenese und Überliferung. Angewandte Methoden der Frühmittelalterforschung. Hrsg. Brunner, K. - Merta, B. [Veröffentlichungen des Instituts für Österreichische Geschichtsforschung 31.] München 1994, 59-67.

BALDWIN $1980=$ Baldwin, B.: Priscus of Panium. Byzantion 50 (1980), 18-61.

BALDWIN 1991a = Baldwin, B.: Asterios of Amaseia. In: $O D B$ 1. 213.

BALDWIN 1991b = Baldwin, B.: Sozomenos. In: ODB 3. 1932-1933.

BALDWIN 1991c = Baldwin, B.: Priskos. In: $O D B$ 3. 1721.

BALDWIN 1991d = Baldwin, B.: Zosimos. In: $O D B$ 3. 2231.

BALDWIN 1991e = Baldwin, B.: George of Pisida. In: $O D B$ 2. 838.

BALDWIN 1991f= Baldwin, B.: Chronicon Paschale. In: $O D B$ 2. 447.

BÁLINT 1989 = Bálint, Cs.: Die Archäologie der Steppe. Völkerschaften zwischen Volga und Donau in 6. -10. Jahrhundert. Wien-Köln 1989.

BÁLINT 1995 = Bálint Cs.: Kelet, a korai avarok és Bizánc kapcsolatai (régészeti tanulmányok). [Magyar Östörténeti Könyvtár 8.] Szeged 1995.

BÁLINT 2004a = Bálint Cs.: A középavar kor kezdete és Kuber bevándorlása. Archaeológiai Értesítő 129 (2004), 35-65.

BÁLINT 2004b = Bálint Cs.: A nagyszentmiklósi kincs. Régészeti tanulmányok. [Varia Archaeologica Hungarica 16a.] Budapest 2004.

BÁLINT 2010 = Bálint Cs.: A contribution to research on ethnicity: a view from and on the east. In: Archaeology of Identity - Archäologie der Identität. Hrsg. Pohl, W. Mehofer, M. [Österreichische Akademie der Wissenschaften. Philosphisch- 
Historische Klasse. Denkschriften 406. Forschungen zur Geschichte des Mittelalters 17.] Wien 2010, 145-182.

BALOGH 2010 = Balogh Cs.: A Felgyő, Ürmös-tanyai avar kori temető. In: Felgyö Ürmöstanya. Bronzkori és avar kori leletek László Gyula felgyői ásatásának anyagából. Szerk. Balogh Cs. - Türk. A. [A Móra Ferenc Múzeum Évkönyve. Monumenta Archaeologica 1.] Szeged 2010, 185-382.

BÁRDOS-GARAM 2009 = Bárdos E. - Garam É.: Das awarenzeithliche Gräberfeld in Zamárdi-Rétiföldek I. [Monumenta Avarorum Archaeologica 9.] Budapest 2009.

BARFIELD 1992 = Barfield, T. J.: The Perilous Frontier. Nomadic Empires and China 221 $B C$ to $A D$ 1757. Cambridge $1992 .^{2}$

BARNISH 1992 = Barnish, S.: Old Kaspars: Attila's invasion of Gaul in the literary sources. In: Fifth-century Gaul: a crisis of identity? Ed. Drinkwater, J. - Elton, H. Cambridge 1992, 38-47.

BARTOSIEWICZ 2009 = Bartosiewicz, L.: Gondolatok a „lovas nomád” hagyományról. In: Csontvázak a szekrényböl. Válogatott tanulmányok a Magyar Archaeozoológusok Visegrádi Találkozóinak anyagából 2002-2009. Szerk. Bartosiewicz, L. - Gál E. Kováts I. Budapest 2009, 73-82.

BELENIZKI 1980 = Belenizki, A. M.: Mittelasien. Kunst der Sogden. Leipzig 1980.

BENDE 1998 = Bende L.: A pitvarosi késő avar kori temető 51. sírja (Adatok a késő avar kor lószerszámok díszítéséhez). A Móra Ferenc Múzeum Évkönyve - Studia Archaeologica 4 (1998), 195-230.

BenNeTt 2001 = Bennett, M. (ed.): Dictionary of Ancient and Medieval Warfare. 2001.

BERTA 1992 = Berta Á.: A türk hadi müszavak egyik jelentéstani csoportja. Keletkutatás 22 (1992), 20-26.

BERTA 2004 = Berta Á.: Szavaimat jól halljátok ... A türk és ujgur rovásírásos emlékek kritikai kiadása. Szeged 2004.

BEZUGLOV 1997 = Безуглов, С. И.: Воинское позднесарматское погребение близ Азова. In: Историко-археологические исследования в Азове и на Нижнем Дону в 1994 г. Ред.: Кияшко, В. Я. Азов 1997, 133-142.

Bezuglov 2000 = Безуглов, С. И.: Позднесарматские мечи (по материалам Полонья). In: Сарматы и их соседи на Дону. Материаль и исследования по археологии Дона. Ред.: Гугуев, Ю. К. Ростов-на-Дону 2000, 169-193.

BLOCKLEY 1972 = Blockley, R. C.: Dexippus and Priscus and the Thucydidean account of the siege of Plataea. Phoenix 26 (1972), 18-27. 
BLOCKLEY 1981 = Blockley, R. C.: The Fragmentary classicising Historians of the later Roman Empire. Eunapius, Olympiodorus, Priscus and Malchus. I. [Classical and Medieval texts, Papers and Monographs 6.] Liverpool 1981.

BLOCKLEY 1983 = Blockley, R. C.: The Fragmentary classicising Historians of the later Roman Empire. Eunapius, Olympiodorus, Priscus and Malchus. II. [Classical and Medieval texts, Papers and Monographs 10.] Liverpool 1983.

BLOCKLEY 1985 = The History of Menander the Guardsman. Trans. Blockley, R. C. [ARCA 17.] Ottawa 1985/Glossar B I. 106-112.

BóNA 1970 = Bóna, I.: Avar lovassír Iváncsáról. Archaeológiai Értesítő 97 (1970), 243263.

BóNA 1971 = Bóna, I.: Eine Vierteljahrhundert Völkerwanderungszeitforschung in Ungarn. Acta Archaeologica Academiae Scientarium Hungaricae 23 (1971), 265-336.

BóNA 1980 = Bóna, I.: Studien zum fruhawarischen Reitergrab von Szegvar. Acta Archaeologica Academiae Scientiarum Hungaricae 32 (1980), 31-95.

BóNA 1981 = Bóna, I.: Das erste Auftreten der Bulgaren im Karpatenbecken. TurkicBulgarian Hungarian Relations (VI-XI. centuries) 5 (1981), 79-112.

BóNA 1984 = Bóna I.: A népvándorláskor és kora középkor története. In: Magyarország története I/1. Főszerk. Székely Gy. Szerk. Bartha A. Budapest 1984, 310-346.

BÓNA 1986 = Bóna I.: Dáciától Erdőelvéig. A népvándorlás kora Erdélyben (271-896). In: Erdély története I. Szerk. MAKKAI L. - MócSY A. Budapest 1986, 162-136.

BóNA 1993a = Bóna I.: A hunok és nagy királyaik. Budapest 1993.

BóNA 1993a = Bóna I.: Hun aranyíj. In: Hunok-gepidák-langobardok. Történeti tézisek és címszavak. Összeállította: Bóna I. [Magyar Östörténeti Könyvtár 6.] Szeged 1993, 24.

BóNA 1994 = Bóna I.: Az Avar birodalom végnapjai. Viták és új eredmények. In: Honfoglalás és régészet. Szerk. Kovács L. [Honfoglalásról Sok Szemmel 1.] Budapest 1994, 67-75.

BÓNA-NAGY 2000 = Bóna I. - NAGY M.: Gepidische Gräberfelder am Theissgebiet 1.

[Monumenta Germanorum Archaeologica Hungariae 1.] Budapest 2000.

BoswORTH 1977 = Bosworth, A. B.: Arrian and Alani. Harvard Studies in Classical Philology 81 (1977), 217-255.

BOURAS $1991=$ Bouras, Ch.: Corippus. In: $O D B$ 1. 533. 
BRÉHIER 2003 = Bréhier, L.: A bizánci birodalom intézményei. [Varia Byzantina 7.] Budapest 2003.

CZEGLÉDY 1959 = Czeglédy K.: A korai kazár történelem forrásainak kritikájához. Magyar Tudományos Akadémia Nyelv- és Irodalomtudományi Osztályának Közleményi 15 (1959), 107-128.

CZEGLÉDY 1969 = Czeglédy K.: Nomád népek vándorlása Napkelettől Napnyugatig.

[Kőrösi Csoma Kiskönyvtár 8.] Budapest 1969.

Christensen 2002 = Christensen, A. S.: Cassiodorus, Jordanes and the History of the Gets. Copenhagen. 2002, 84-123.

CH’Ü-HSÜN 1960 = Ch'ü-hsün, K.: The Ching Lu Shen Shrines of Han Sword worship in Hsiung nu Religion. Central Asiatic Journal 5 (1960), 221-232.

Clover 1971 = Clover, F. M.: Flavius Merobaudes. In: Flavius Merobaudes. Trans. Clover, F. M. [Transactions of the American Philosophical Society 61.] Philadelphia 1971, 7-10.

COUlStOn $2002=$ Coulston, J.: Arms and Armour of the Late Roman Army. In: $A$ Companion to Medieval Arms and Armour. Ed. Nicolle, D. Woodbridge 2002, 324.

COUPLAND $1990=$ Coupland, S.: Carolingian Arms and Armor in the ninth century. Viator . Medieval and Renaissance Studies 21 (1990), 29-50.

CURTA 2008 = Curta, F.: The earliest Avar-age stirrups, or the „sirrups controversy.” In: The Other Europe in the Middle Ages. Avars, Bulgars, Khazars, and Cumans. [East Central and Eastern Europe in the Middle Ages, 450-1450. 2.] Ed. Curta, F. Leiden-Boston 2008, 297-326.

CUTLER 1991 = Cutler, A.: Nikephoros I. In: $O D B$ 3. 1477.

CSALLÁNY 1939 = Csallány D.: Kora-avarkori sírleletek. Folia Archaeologica 1-2:19381939 (1939), 121-180.

CSALLÁNY 1946-1948 = Csallány D.: Szegedi avarkori sírleletek és hun-bolgár ivókürtök régészeti kapcsolatai. Archaeologiai Értesítő 7-8 (1946-1948), 350-361.

CSAlláNY 1953 = Csallány D.: A bácsújfalusi avarkori hamvasztásos lelet. Adatok a kutrugur-bulgárok (hunok) temetési szokásához és régészeti hagyatékáról. Archaeológiai Értesítő 80 (1953), 133-140.

CSALLÁNY 1960a = Csallány D.: Szabolcs-Szatmár megye avar leletei. A Nyíregyházi Jósa András Múzeum Évkönyve 1:1958 (1960), 31-87. 
Csallány 1960b = Csallány D.: A hajdúdorogi avar mellpáncél. A Debreceni Déri Múzeum Évkönyve 45:1958-1959 (1960), 17-23.

CSALLÁNY 1963 = Csallány D.: A kutrugur-bulgárok (-hunok) régészeti hagyatékának meghatározása. Archaeológiai Értesitő 90 (1963), 21-38.

CSALLÁNY 1972 = Csallány D.: Avarkori páncélok a Kárpát-medencében I. A Nyíregyházi Jósa András Múzeum Évkönyve 13-14:1969-1971 (1972), 7-44.

CSALLÁNY 1982 = Csallány D.: Avarkori páncélok a Kárpát-medencében II. A Nyíregyházi Jósa András Múzeum Évkönyve 15-17:1972-74 (1982), 5-35

CSIKY 2007 = Csiky G.: A kora avar kori lándzsák tipológiája. Archaeologiai Értesítö 132 (2007), 305-323.

CSIKY 2009 = Csiky G.: Az avar kori szúró- és vágófegyverek. Osztályozás - tipológia kronológia-technológia. Doktori értekezés. Kézirat. Budapest 2009.

CSIKY 2012 = Csiky, G.: Saxe im Awarenzeitlichen Karpatenbecken. In: Thesaurus Avarorum. Régészeti tanulmányok Garam Éva tiszteletére. Szerk. Vida T. Budapest 2012, 371-393.

CSIKY 2013 = Csiky G.: Az avar közelharci fegyverek története. Funkcionális megközelítés. Dolgozatok az Erdélyi Múzeum Érem- és Régiségtárából (Új sorozat) 6-7/16-17: 2011-2012/ (2013), 71-92.

Cs. SEBESTYÉN $1930=$ Cs. Sebestyén K.: Rejtéjes csontok népvándorláskori sírokban. Dolgozatok a Szegedi Tudományegyetem Régiségtudományi Intézetéből 6 (1930), $178-220$.

Cs. Sós 1958 = Cs. Sós, Á.: Das frühawarenzeitliche Gräberfeld von Oroszlány. Folia Archaeologica 10 (1958), 104-124.,

Cs. Sós 1968 = Cs. Sós, Á.: Archäologische Angaben zur Frage der Frühperiode des awarisch-slawischen Zusammenlebens. Študijné zvesti Archeologického ústavu Slovenskej akademie vied 16 (1968), 221-231.

CSUTHY 2012 = Csuthy A.: A késő avar kori füles lószerszámveretek. In: Hadak útján XX. Népvándorláskori Fiatal Kutatóinak XX. Összejövetelének konferenciakötete. Budapest-Szigethalom, 2010. október 28-30. Szerk. Petkes Zs. Budapest 2012, $163-186$.

DARKÓ 1915 = Darkó J.: Bölcs Leó Taktikájának hitelessége magyar történeti szempontból. Székfoglaló. [Értekezések a nyelv- és széptudományok köréből 23/4.]

DARKÓ 1934 = Darkó J.: Turáni hatások a görög-római hadügy fejlődésében. Hadtörténelmi Közlemények 35 (1934), 3-40. 
DARKÓ 1935 = Darkó, E.: Influences Touraniennes sur L'évolution de L'art Militaire des Grecs, des Romains et de Byzantins. Byzantion 10 (1935), 444-469.

DARKÓ 1937 = Darkó, E.: Influences Touraniennes sur L'évolution de L'art Militaire des Grecs, des Romains et de Byzantins. Byzantion 12 (1937), 119-147.

Dennis-Gamillscheg 1981 = Dennis, G. T. - Gamillscheg, E. (trans.): Mauricii Strategicon - Das Strategicon des Maurikios. Ed. Dennis, G. T., Germanice vertit Gamillscheg, E. [Corpus Fontium Historiae Byzantinae 17.] Vindobonae 1981.

DenNIS 1985 = Dennis, G. T. (trans.): The Anonymus Byzantine Treatise on Strategy. In: Three Byzantine military Treatises. [Corpus Fontium Historiae Byzantinae 25.] Washington 1985, 1-136.

DiCKens 2008 = Dickens, M.: Turkāyē. Turkic Peoples in Syriac Literature Prior to the Seljüks. Dissertation submitted for the degree of Doctor of Philosophy. Manuscript. Cambridge 2008.

DIENES 1969 = Dienes I.: Megjegyzések Fettich Nándor válaszához. Archaeologiai Értesitö 96 (1969), 116-122.

DIMNIK 1994 = Dimnik, M.: The dynasty of Chernigov (1054-1146). Toronto 1994.

DoBos 2013 = Dobos A.: Gepidák vagy avarok? Az erdélyi kora avar kori soros temetők kutatásának kérdéseiről. Dolgozatok az Erdélyi Múzeum Érem-és Régiségtárából (Új sorozat) 6-7/16-17: 2011-2012/ (2013), 93-118.

Doszimbajeva-Golden-Oszava 2013 = Досымбаева, А. М. - Голден, П. - Осава, Т.: Из истории Западного Тюркского каганата. Общие вопросы становления и истории государства. In: Западный Тюркский каганат. Атлас. Ред. Досымбаева, А. - Жолдасбеков, М. Астана 2013, 10-99.

ERDÉLYI 1982 = Erdélyi I.: Az avarság és kelet a régészeti források körében. Budapest 1982

FANCSALSZKY 2007 = Fancsalszky G.: Állat- és emberábrázolás a késő avar kori öntött bronz övvereteken. [Opitz Archaeologica 1.] Budapest 2007.

FARKAS 2001 = Farkas Cs.: Megjegyzések a steppe 603 körüli történetének forrásaihoz. In: A Kárpát-medence és a steppe. Szerk. Márton A. [Magyar Östörténeti Könyvtár 14.] Budapest 2001, 61-65.

FEHÉR 1955 = Fehér G.: Avar-bizánci kapcsolatok és a bolgár államalapítás. Archaeológiai Értesítő 82 (1955), 45-47. 
FEJős 2001 = Fejös B.: Az alán és az ász név összefüggése a középkori forrásokban. In: $A$ Kárpát-medence és a steppe. Szerk. Márton A. [Magyar Östörténeti Könyvtár 14.] Budapest 2001, 7-14.

FELFÖLDI 2004 = Felföldi Sz.: A nomád hadviselés egyik jellegzetes problémája: a folyón való átkelés. In: Fegyveres nomádok, nomád fegyverek. III. Szegedi Steppetörténeti Konferencia Szeged, 2002. szeptember 9-10. Szerk. Balog L. - KELLER L. [Magyar Östörténeti Könyvtár 21.] Budapest 2004, 75-91.

FERRILL 1986 = Ferrill, A.: The Fall of the Roman Empire. The Military Explanation . London 1986.

FIEBIGER 1920 = Fiebiger, O.: Sagitta. In: Paulys Realencyclopädie der classischen Altertumswissenschaft I. A 2. Hrsg. Kroll, W. München 1920, 1741-1746.

FINÁLy 1884 = Finaly H.: A latin nyelv szótára a kútfökböl. A legjobb és legújabb szakirodalomra támaszkodva. Budapest 1884.

FiSCHER-FABIAN 2000 = Fischer-Fabian, S.: Nagy Károly, az első európai. Szombathely 2000.

FODOR 2000 = Fodor I.: A bécsi szablya és a prágai kard. Szeged 2000.

FOLKERTS 1980 = Folkerts, M.: Alkuin (Alcuin, Alchwine). In: LexMa 1. 417-420.

FRANK 1991 = Frank, K. S.: Hieronymus. In: LexMA 5. 2-4.

FREEDEN 1995 = Awarische Funde in Süddeutschland? Jahrbuch des RömischGermanischen Zentralmuseums 38:1991 (1995), 593-627.

FÜGEDI 1946-1948 = Fügedi E.: Avarok és morvaszlávok. Archaeológiai Értesitő 75 (1946-1948), 312-338.

GABAIN 1973 = Gabain, A.: Das Leben im uigurischen Königreich von Qoco (850-1250).

[Veröffentlichungen der Societas Uralo-Altaica 6.] Wiesbaden 1973.

Galamb 2012 = Galamb Gy. (közreadja): Paulus Diaconus. A langobardok története.

[Mediaevalia] Budapest 2012.

GARAM 1991 = Garam É.: Tiszakécskei-óbögi avarkori sírok. Adatok az avarkori szablyákhoz és az egyenes, egyélü kardokhoz. Communicationes Archaeologicae Hungariae 1991. 129-163.

GARAM 1995 = Garam, É.: Das awarenzeitliche Gräberfeld von Tiszafüred. [Cemeteries of the Avar Period (567-829) in Hungary 3.] Budapest 1995.

GASPARRI 1993 = Gasparri, St.: In: LexMA 6. 1825-1826.

GIEßAUF 2004 = Gießauf, J.: A lovasnomád fegyverzet és harcmodor az ellenfelek beszámolóinak tükrében. In: Fegyveres nomádok, nomád fegyverek. III. Szegedi 
Steppetörténeti Konferencia Szeged, 2002. szeptember 9-10. Szerk. Balogh L. Keller L. [Magyar Östörténeti Könyvtár 21.] Budapest 2004, 26-37.

GLARE 2000 = Glare, P. G. (ed.): Oxford Latin Dictionary. Oxford 2000.

GOLDEN 1992 = Golden, P. B.: An Introduction to the History of the Turcic Peoples.

Etnogenesis and State-Formation in Medieval and Early Modern Eurasia and the Middle East. Wiesbaden 1992.

GoldEN $2001=$ Golden, P. B.: Some Notes on the Comitatus in Medieval Eurasia with Special Reference to the Khazars. Russian History 28 (2001), 153-170.

GolDEN 2002 = Golden, P. B.: War and Warfare in the Pre-Činggisid Western Steppes of Eurasia. In: Warfare in Inner Asian History. Ed. Cosmo, N. D. Brill 2002, 105-171. Golden 2004 = Golden, P. B.: Khazar Turkic Ghulâms in Caliphal Servise. Journal Asiatique 292 (2004), 279-309.

GÖCKENJAN 1997 = Göckenjan, H.: Eskü és szerződés az altaji népeknél. In: Honfoglalás és néprajz. Szerk. Kovács L. - Paládi-Kovács L. [Honfoglalásról Sok Szemmel 4.] Budapest 1997, 333-346.

GÖCKENJAN 2001 = Göckenjan, H.: Felderítők, kémek. Tanulmány a lovasnomád hadviselés stratégiájáról és taktikájáról. In: Nomád népvándorlások, magyar honfoglalás. Szerk. Felföldi Sz. - Sinkovics B. [Magyar Östörténeti Könyvtár 15.] Budapest 2001, 57-66.

GöCKENJAN 2004 = Göckenjan, H.: Lobogó és dob az altaji népeknél. In: Fegyveres nomádok, nomád fegyverek. III. Szegedi Steppetörténeti Konferencia Szeged, 2002. szeptember 9-10. Szerk. Balogh L. - Keller L. [Magyar Östörténeti Könyvtár 21.] Budapest 2004, 62-74.

GÖCKENJAN 2005 = Göckenjan, H.: Bogen, Pfeil und Köcher in der Herrschafts- und Rechtssymbolik der eurasischen Steppenvölker. Acta Orientalia Academiae Scientiarum Hungaricae 58 (2005), 59-76.

GÖCKENJAN 2007 = Göckenjan, H.: Der Waffengürtel der altaischen Völker als Trachtbestandteil, Symbolträger und Rangabzeichen. In: Ungarn, Türken und Mongolen. Kleine Schriften von Hansgerd Göckenjan. Hrsg. Knüppel, M. Winker, E. Wiesbaden 2007, 361-396.

GÖCKENJAN-ZIMONYI 2001 = Göckenjan, H. -Zimonyi, I.: Orientalische Berichte über die Völker Osteuropas und Zentralasiens im Mittelalter. Die Ğayhān̄i-Tradition (Ibn Rusta, Gardīzī, Hudūd al-'Ālam, al-Bakrī und al-Marwazī). [Veröffentlichungen der Societas Uralo-Altaica 54.] Wiesbaden 2001. 
Grosse 1927 = Grosse, R.: Lorica, in: Paulys Realencyclopädie der classischen Altertumswissenschaft. 13. 2. Hrsg. Kroll, W. München 1927, 1444-1449.

GRUBER 1986 = Gruber, J.: Corippus (Flavius Cresconius Corippus). In: LexMa 3. 237.

GRUBER $1980=$ Gruber, J.: Merobaudes. In: LexMa 6. 542.

GRÜNBECK 1995 = Grübbeck, E.: Sidonius Appolinaris. In: LexMa 7. 1834-1835.

GYOMLAY 1902 = Gyomlay Gy.: Bölcs Leo taktikája mint magyar történeti kútforrás. Budapest 1902.

GYÖRFFY-KAKUK-NÉMETH 1996 = Györffy Gy. - Kakuk Zs. - Németh Gy.: Az orkhoni feliratok (részlet). In: A honfoglaláskor írott forrásai. Szerk. Kovács L. Veszprémy L. [A Honfoglalásról Sok Szemmel 2.] Budapest 1996, 23-28.

GYÖRKÖSY-KAPITÁNFFY-TEGYEY 1990 = Györkösy A. - Kapitánffy I. - Tegyey I.: Ógörög-magyar szótár. Budapest 1990.

HAHN 1963 = Hahn I.: Az ókori hadmüvészet fejlődésének áttekintése. In: A hadmüvészet ókori klasszikusai. Szerk. Hahn I. Budapest 1963, 11-128.

HALMÁGYI 2007 = Halmágyi M.: Középkori csatakiáltások. Hadtörténelmi Közlemények 120 (2007), 590-601.

HARMATTA 1951 = Harmatta J.: A hún aranyíj. MTA II. Társadalmi-Történeti Tudományok Osztályának Közleményei 1 (1951), 123-187.

HARMATTA 1985 = Harmatta J.: Avar rovásírásos tárgyfeliratok. Antik Tanulmányok 32 (1985), 57-72.

HAZANOV 1968 = Хазанов, А. М.: Катафрактарии и их роль в истории военного искусства. Вестник древней истории 103 (1968), 180-191.

HAZANOV 1971 = Хазанов, А. М.: Очерки военного дело сарматов. Москва 1971.

HIDÁN 2000 = Hidán Cs.: Mit jelent a könnyü-, és mit jelent a nehézlovas? Terminológiai problémák az „eurázsiai nomád” lovassággal kapcsolatban. Társadalom és Honvédelem 4 (2000), 7-20.

HILL 1973 = Hill D. R.: Trebuchets. Viator 4 (1973), 99-116.

HOFFMANN 2005 = Hoffmann, B.: Das Ilkhanat - Geschichte und Kultur Irans von der mongolischen Eroberung bis zum Ende der Ilkhanzeit (1220-1335). In: Dschingis Khan und seine Erben. Das Weltreich der Mongolen. Katalogbuch zur Ausstellung. 16. Juni bis 25. September 2005 Kunst- und Ausstellungschalle der Bundesrepublik Deutschland, Bonn. 26. Oktober 2005 bis 29. Januar 2006 Staatliches Museum für Völkerkunde München.

HORVÁTH 2005 = Horváth Sz.: Iordanes élete és műve. In: Kiss 2005, 1-12. 
HUSÁR 2007 = Husár, M.: Ikonografické doklady jazdcov s kopijami a oštepmi z územija avarského kaganátu. Studia Historica Nitriensia 12 (2007), 29-41.

H. TóTH $1990=$ H. Tóth E.: Késői hun örökség a kunbábonyi kagáni sír leletei között. Múzeumi Kutatások Bács-Kiskunmegyében 1988 (1990), 5-15.

H. Tóth-Horváth 1992 = H. Tóth, E. - Horváth, A.: Kunbábony das Grab eines Awarenkhagans. Kecskemét 1992.

IVANIŠEVIĆ-BUGARSKI 2012 = Ivanišević, V. - Bugarski, I.: Les étriers Byzantins: La documentation du Balkan central. In: Le cheval dans les sociétés antiques et médiévales. Actes des Journées internationales d'étude (Strasbourg, 6-7 novembre 2009). Ed. Lazaris, S. [Bibliothèque de l'Antiquité tardive 22] Turnhout 2012, 135277.

JÓzSA 2006 = Józsa L.: Paleopathologia. Elödeink betegségei. Budapest 2006.

KAEGI $1990=$ Kaegi, W. E.: Procopius the Militarty Historian. Byzantinische Forschungen 15 (1990), 53-85.

KAFESOĞLU 1988 = Kafesoğlu, I.: A History of Seljuks. Ibrahim Kafesoğlu's Interpretation and the Resulting Controversy. Trans. and Ed. Leiser, G. Carbondale-Edwardsville 1988.

KÁKÓCZKI 2012 = Kákóczki B.: Vegetius: Epitoma rei Militaris. Az „Epitoma” hatása a középkori (had)tudományos irodalomra. Doktori értekezés. Kézirat. Debrecen 2012.

KAKUK 1985 = Kakuk Zs. (szerk.): Örök köbe vésve. A régi török népek irodalmának kistükre a VII-töl a XV. századig. Budapest 1985.

KALMÁR 1944-1945 = Kalmár J.: Az avar nyílhegy. Archaeologiai Értesítő 5-6 (19441945), 283-293.

KARDARAS 2005 = Kardaras, G.: The Episode of Bousas (586/7) and the Use of Siege Engines by the Avars. Byzantinoslavica 63 (2005), 53-66.

KATONA 1981 = Katona T. (szerk.): A tatárjárás emlékezete. Budapest 1981.

KAZHDAN 1991a = Kazhdan, A.: Spatharios. In: ODB 3. 1935-1936.

KAZHDAN 1991b = Kazhdan, A.: Historiography. In: $O D B$ 2. 937-938.

KAZHDAN 1991c = Kazhdan, A.: Suda. In: ODB 3. 1930-1931.

KAZHDAN 1991d = Kazhdan, A.: Theodore Synkllos. In: $O D B$ 3. 2048.

KAZHDAN 1991e = Kazhdan, A.: Zonaras, John. . In: ODB 3. 2229.

KAZHDAN 1991f= Kazhdan, A.: Manasses, Constantine. In: ODB 2. 1280. 
KELLER 2004 = Keller L.: Türk harcos és fegyverei az írott források tükrében. In: Fegyveres nomádok, nomád fegyverek. III. Szegedi Steppetörténeti Konferencia Szeged, 2002. szeptember 9-10. Szerk. Balogh L. - Keller L. [Magyar Östörténeti Könyvtár 21.] Budapest 2004, 45-52.

KESZI $2001=$ Keszi T.: Attila és a nyergekből rakott máglya. [Hadak útján XII. „Régiók és kistájak a népvándorlás korában.” A népvándorlás kor fiatal kutatói konferenciájának előadásai (Simontornya, 2001. szeptember 3-5.) Szerk. Gaál A.] A Wosinszky Mór Múzeum Évkönyve 23 (2001), 63-67.

KING 1987 = King, Ch.: The Veracity of Ammianus Marcellinus' description of the Huns. American Journal of Ancient History 12.1 (1987), 77-95.

KISS $1992=$ Kiss, A.: Germanen im awarenzeitlichen Karpatenbecken. In: Awarenforschungen. Hrsg. Daim, F. [Archaeologia Austriaca Monographien 1.] Wien 1992.

KISs 1996 = Kiss, A.: Das awarenzeitliche gepidische Gräberfeld von Kölked-Feketekapu A. [Monographien zur Frühgeschichte und Mittelalterarchäologie 2.] Innsbruck 1996.

KISS $1997=$ Kiss A.: Az avar kori tegezek csontlemezeinek kronológiájához. Archaeologiai Értesítö 123-124 (1997), 75-83.

KISS $2001=$ Kiss, A.: Das awarenzeitliche Gräberfeld in Kölked-Feketekapu B. [Monumenta Avarorum Archaeologica 6.] Budapest 2001.

KISS 1991 = Kiss G.: A Szombathely-Kőszegi úti avar lovassír (a késő avar kori négy- és ötkaréjos lószerszámveretek). A Móra Ferenc Múzeum Évkönyve 1984/1985-2 (1991), 431-462.

KISS 1993 = Kiss G.: A vasasszonyfai avar temető lovassírjai (A késő avar kori kétkaréjos és lapos rozettás lószerszámveretek). A Herman Ottó Múzeum Évkönyve 30-31 (1993), 197-224.

KISS 1996 = Kiss G.: A lukácsházi avar temető 8. számú lovassírja. A késő avar tausírozott vasfalerák. Savaria PA 22:1992-1993 (1996), 107-143.

Kiss P. 2010a = Kiss P. A.: Germán népek részvétele a hunok hadjárataiban. Hadtörténelmi Közlemények 123 (2010), 137-167.

Kiss P. $2010 \mathrm{~b}=$ Kiss P. A.: A gepidák avar kori továbbélésének vizsgálatáról. In: Középkortörténeti tanulmányok 6. A VI. Medievisztika PhD-konferencia (Szeged, 2009. június 4-5.) előadásai. Szerk. G. Tóth P. - Szabó P. Szeged 2010, 119-134. 
KISS P. 2012 = Kiss P. A.: „Nem a hadnak sokasága...” Megjegyzések a Tisza-vidéki gepida fegyveres réteg összetételéhez. In: Középkortörténeti tanulmányok 7. A VII. Medievisztikai PhD-konferencia (Szeged, 2011. június 1-3.) elöadásai. Szerk. Kiss P. A. - Piti F. - Szabados F. Szeged 2012, 135-164.

KMOSKÓ 2000 = Kmoskó M.: Mohamedán írók a steppe népeiröl. Földrajzi irodalom I/2. Szerk. Zimony I. [Magyar Östörténeti Könyvtár 13.] Budapest 2000.

KMOSKÓ 2004 = Kmoskó M.: Szír írók a steppe népeiröl. Szerk. Felföldi Sz. [Magyar Östörténeti Könyvtár 20.] Budapest 2004.

KoCsIS $2010=$ Kocsis L.: A tiszagyendai régészeti ásatás (2006-2007) leletei. In: Örök megújulás. Az ezredforduló új szerzeményei a Magyar Nemzeti Múzeumban. Kiállítási katalógus (2010. január 18 - május 30.) Szerk. Pallos L. Budapest 2010, $17-19$.

KollaUtZ-MiYaKawa 1970 = Kollautz, A. - Miyakawa, H.: Geschichte und Kultur eines völkerwanderungszeitlichen Nomadenvolkes. Die Jou-Jan, der Mongolei und die Awaren in Mitteleuropa. 1. Klagenfurt 1970.

Kolias $1988=$ Kolias, T.: Byzantinische Waffen. Wien 1988.

KovÁCS 1913 = Kovács I.: Mezőbándi ásatások. Dolgozatok az Erdélyi Nemzeti Múzeum Érem- és Régiségtárából 4/2 (1913), 279-381

KOvÁCS 2002 = Kovács L.: A honfoglaló magyarok bőrpáncéljáról. Hadtörténelmi Közlemények 115 (2002), 311-334.

KovÁcs 2003 = Kovács L.: Viselet, fegyverek. In: Kristó Gy.: Háborúk és hadviselés az Árpádok korában. Szeged 2003, ${ }^{2}$ 284-392.

KovÁcs 2009 = Kovács Sz.: A kunok és a lebunioni csata. In: „Kun kép” $A$ magyarországi kunok hagyatéka. Tanulmányok Horváth Ferenc 60. születésnapja tiszteletére. Szerk. Rosta Sz. Kiskunfélegyháza 2009, 273-289.

KovÁcs 2012 = Kovács Sz.: A kunok története a mongol hóditásig. Doktori értekezés. Kézirat. Szeged 2012.

KOVRIG 1955 = Kovrig I.: Adatok az avar megszállás kérdéséhez. Archaeológiai Értesitő 82 (1955), 30-44.

U. KÖHALMI 1972 = U. Köhalmi K.: A steppék nomádjai, lóháton, fegyverben. [Kőrösi Csoma Kiskönyvtár 12.] Budapest 1972.

KRAFT $1980=$ Kraft, H.: Asterius I. In: LexMa 1. 1127-1128.

Kubarev-Kubarev-BajÁr 2013 = Кубарев, В.Д. - Кубарев, Г.В. - Баяр Д.: Памятники на территории Алтая и Монголии. In: Западныгй Тюркский 
каганат. Атлас. Ред. Досымбаева, А. - Жолдасбеков, М. Астана 2013, 607651.

KulcsÁr-ISTVÁNOVITS 2013 = Кульчар, В. - Иштванович, Э.: Новая находка седельных обкладок гуннского времени из Северо-Восточной Венгрии. Stratum plus. Археология и культурная антропология 4 (2013), 1-6.

KulCSÁR-IstVÁNOVITS 2014 = KulcsÁR, V. - Istvánovits, E.: New Find of Hun Age Saddle Plates from North-East Hungary. In: Archäologische Beiträge. Gedenkschrift zum hundertsten Geburtstag von Kurt Horedt. Hrsg. CoCiş, S. [Patrimonium Archaeologicum Transylvanicum 7.] Cluj-Napoca 2014, 269-278.

Kurz 1983 = Kurz, R.: Claudius. I. C., Claudius. In: LexMa 2. 2130-2131.

KÜRTI 2003 = Kürti B.: Az avarok szekere. Múzeumi Kutatások Csongrád Megyében 2002 (2003), 33-39.

KÜRTI 2007 = Kürti, B.: Fürstliche Funde der Hunnenzeit von Szeged-Nagyszéksós. In: Attila und die Hunnen. Hrsg. Historischen Museum der Pfalz Speyer. Stuttgart 2007, 258-261.

KÜRTI-LÖRINCZY 1991 = Kürti B. - Lörinczy G..,, ...avarnak mondták magukat...” Vezető a Móra Ferenc Múzeum régészeti kiálltásában. Szeged 1991.

LAMMERT 1938 = Lammert, F.: Die antike Poliorketik und ihr Weiterwirken. Klio 31 (1938), 389-411.

LÁSzLÓ 1909 = László B.: Adalékok az antik lövegtan történetéhez. Egyetemes Philologiai Közlöny 33 (1909), 778-781.

LÁSZLÓ 1940 = László GY.: Újabb keresztény nyomok az avarkorból. Dolgozatok a Szegedi Tudományegyetem Régiségtudományi Intézetéből 16 (1940), 145-158.

LÁSzLÓ 1951 = László Gy.: A hún aranyíj jelentősége. Adatok a hún nomád-birodalom szerkezetéhez. MTA II. Társadalmi-Történeti Tudományok Osztályának Közleményei 1 (1951), 105-122.

LÁSZLó 1976 = László Gy.: A bócsai fejedelmi sír és a keceli kard. Cumania 4 (1976), 89_ 114.

LEMERLE 1979 = Lemerle, P.: Introduction. In: Les plus anciens recueils des miracles de Saint Démétrius I. Le texte par Lemerle, P. Éditions du Centre national de la recherche scientifique. Paris 1979, 9-42.

LEMERLE 1981 = Lemerle, P.: Les plus anciens recueils des miracles de Saint Démétrius. Et la Pénétration des Slaves dans les Balkans II. Comentaire. Paris 1981. 
LENZ 1931 = Lenz, O.: Merobaudes. In: Paulys Realencyclopädie der classischen Altertumswissenschaft 14. Begr. Pauly, A. F. Stuttgart 1931, 1039-1047.

LEXMA = Lexikon des Mittelalters 1-9. Hrsg. Bautier, R. H. u.a. München-Zürich 19801998

LidDEL et al. 1958 = Liddel, H. G. - Scott, R. - Jones, S. H. - McKenzie, R. (ed.): $A$ Greek-English lexicon. Cambridge 1958.

LindNER $1981=$ Lindner, R. P.: Nomadism, Horses and Huns. Past and Present 92 (1981), 3-19.

LINDNER 1982 = Lindner, R. P.: What was a Nomadic Tribe? Comparative Studies in Society and History 24 (1982), 689-711.

LINDERSKI 1996 = Linderski, J.: Haruspices. In: The Oxford Classical Dictionary. Ed. Hornblower, S. - Spawforth, A. Oxford-New York 1996, 667-668.

LoYen 1969 = Loyen, A.: Le rôle de saint Aignan dans la défense d'Orléans. Comptesrendus des séances de l'Académie des Inscriptions et Belles-Lettres 113 (1969), 6474.

LŐRINCZY 1998 = Lőrinczy G.: Kelet-európai steppei népesség a 6-7. századi Kárpátmedencében. Régészeti adatok a Tiszántúl kora avar kori betelepüléséhez. A Móra Ferenc Múzeum Évkönyve - Studia Archaeologica 4 (1998), 323-372.

LŐRINCZY 2001 = Lőrinczy G.: Kelet-európai népesség a 6-7. századi Kárpát-medencében. In: A Kárpát-medence és a steppe. Szerk. Márton A. [Magyar Östörténeti Könyvtár 14.] Budapest 2001, 40-47.

LŐRINCZY-STRAUB 2012 = Lőrinczy G. - Straub P.: Néhány megjegyzés a HajdúdorogVársokert útil. sírról. In: Thesaurus Avarorum. Régészeti tanulmányok Garam Éva tiszteletére. Szerk. Vida T. Budapest 2012, 397-403.

LuDWIG 1982 = Ludwig, D.: Struktur und Gesellschaft des Chasaren-Reiches im Licht der schriftlichen Quellen. Münster 1982.

MACKERRAS 1972 = Mackerras, C.: The Uigur Empire according to the T'ang Dynastic Histories. A Study in Sino-Uigur Relation 744-840. Canberra 1972.

MAENCHEN-HeLfEN 1997 = Maenchen-Helfen, O. J.: Die Welt der Hunnen. Herkunft, Geschichte, Religion, Gesellschaft, Kriegführung, Kunst, Sprache. Wiesbaden 1997.

Maguinness 1996 = Maguinness, W. S.: Panegyric. In: The Oxford Classical Dictionary. Ed. Hornblower, S. - Spawforth, A. Oxford-New York 1996, 1105. 
MAKKAY 1995 = Makkay J.: Attila kardja, Árpád kardja. Irániak, szarmaták, alánok, jászok. Szeged 1995.

MAKKAY 1999 = Makkay J.: Valter Pannóniában - a Waltharius Hungáriában. In: Ekkhard barát. Vita Waltharii manu fortis. Erös kezü Valter története. Ford. Tulok M. Makkay J. Budapest 1999.

MARSDEN 1969 = Marsden, E. W.: Greek and Roman artillery. Historical Development. Oxford 1969.

MAY 2007 = May, T.: The Mongol Art of War. Yardley 2007.

MCDonAlD-Spawforth 1996 = McDonald, A. H. -Spawforth, A. J. S.: Aurelius Victor, Sextius. In: The Oxford Classical Dictionary. Ed. Hornblower, S. - Spawforth, A. Oxford-New York 1996, 222.

MCGEER 1991 = McGeer, E.: Artillery and siege machinery. In: ODB 1. 195.

MCGEER 1995 = McGeer, E. (ed.): Sowing the Dragon's teeth: Byzantine Warfare in the Tenth Century. Washington 1995.

MesteRhÁzy 1968 = Mesterházy K.: Az utrechti zsoltár avar ábrázolásai. Alba Regia 89:1967-1968 (1968), 245-248.

MeZEI $1988=$ Mezei B. (ford.): Claudius Claudianus versei. Budapest 1988.

MielCZAREK 1993 = Mielczarek, M.: Cataphracti and Clibanarii Studies on the Heavy Armoured Cavalry of the Ancient World. [Studies on the History of Ancient and Medieval Art of Warfare 1.] Łódź 1993.

MogiLnYIKOV 1981 = Могильников, В. А.: Тюрки. In: Степи Евразии в эпоху средневековья. Ред. Плетнева, С. А. [Археология СССР] Москва 1981, 29-42.

MOLNÁR 1993 = Molnár Á.: Időjárás-varázslás Belsö-Ázsiában. [Körösi Csoma Kiskönyvtár 21.] Budapest 1993.

MORAVCSIK 1930 = Moravcsik Gy.: Az onogurok történetéhez. [A Magyar Nyelvtudományi Társaság Kiadványai 27.] Budapest 1930.

MORAVCSIK 1951 = Moravcsik Gy.: Bölcs Leó Taktikája, mint magyar történeti forrás. Századok 85 (1951), 334-353.

MORAVCSIK 1967 = Moravcsik Gy.: A húnok taktikájához. Körösi Csoma Kiskönyvtár 1: 1921-1925 (1967), 276-280.

MORAVCSIK 1958 = Moravcsik, Gy.: Byzantinoturcica I. Die byzantinischen Quellen der Geschichte der Türkvölker. Budapest 1958.

NAGY 2005 = Nagy, K.: Notes on the Arms of Avar Heavy Cavalry. Acta Orientalia Academiae Scientiarum Hungaricae 58/2 (2005), 135-148. 
NAGY 2009 = Nagy K.: Kelet-Európa nomád népei és a kereszténység a 4-7. században. In: Térités - megtérés. A világvallások terjedése Kelet-Európa népei között. Szerk. Balogh L. - Kovács Sz. [Magyar Östörténeti Könyvtár 25.] Budapest 2009, 29-38.

NAGY 2012 = Nagy K.: A sátor leszakítása a halálra ítélés jelképes kifejezése? Egy avar szokás nyomai Theophylaktos Simokattés müvében. In: Középkortörténeti tanulmányok 7. A VII. Medievisztika PhD-konferencia (Szeged, 2011. június 1-3.) előadásai. Szerk. Kiss P. A. - Piti F. - Szabados Gy. Szeged 2012, 185-195.

NAGY 1998 = Nagy, M.: Awarenzeitliche Gräberfelder im Stadtgebiet von Budapest I-II. [Monumenta Avarorum Archaeologica 2.] Budapest 1998.

NAGY 2004 = Nagy M.: A hódmezővásárhely-kishomoki gepida temető (elemzés). A Móra Ferenc Múzeum Évkönyve - Studia Archaeologica 10 (2004), 129-239.

NAGY et al $2000=$ Nagy M. - Neumann, G. - Pohl, W. - B. Tóth Á.: A gepidák. A Móra Ferenc Múzeum Évkönyve - Studia Archaeologica 6 (2000), 165-190.

NÉGYESI 2000 = Négyesi L.: Gondolatok a lovasság csapatnemeiről (a könnyü- és nehézfegyverzetü lovasság problematikája). In: Hadak útján. A népvándorlás kor fiatal kutatóinak konferenciája. Szerk. Bende L. - Lőrinczy G. - Szalontai Cs. Szeged 2000, 375-378.

NÉMETH 1991 = Németh Gy.: A honfoglaló magyarság kialakulása. Közzéteszi Berta Á. Budapest 1991. ${ }^{2}$

NÉMETH 1998 = Németh Gy. (szerk.): Ércnél maradóbb... A görög és római történelem forrásai. Budapest 1998.

NÉMETH 1969 = Németh P.: Újabb avarkori leletek a történeti Veszprém megyéből. A Veszprém Megyei Múzeumok Közleményei 8 (1969), 153-166.

NiCKEL 1973 = Nickel, H.: About the sword of the Huns and the „Ureups” of the Steppes. Metropolitan Museum Journal 7 (1973), 131-142.

NIKONOROV 1998 = Nikonorov, V. P.: Cataphracti, Catafractarii and Clibanarii. Another look at the Old Problem of their identifications. In: Military Archaeology. Weaponry and Warfare in the Historical and Social Perspective. Materials of the International Conference 2-5. September 1998. Ed. Vilinbahov, G. V. - Mason, V. M. St-Petersburg 1998, 131-138.

NiKONOROV 2002 = Nikonorov, V. Р.: Военное дело европейских гуннов в свете данных греко-латинской письменной традиции. Записки Восточного Отделения Российского Археологического Общества (ЗВОРАО) 1 /26/ (2002), 223-323. 
NiKONOROV 2010a = Nikonorov, V. P.: „Like a Certain Tornado of Peoples” Warfare of the European Huns in the Light of Graeco-Latin Literary Tradition. Anabasis. Studia Classica et Orientalia 1 (2010), 264-291.

NiKONOROV 2010b = Никоноров, В. П.: Гуннское воинство Аттилы: конница или пехота? In: Древние культуры Евразии материаль международной научной конференции посвященной 100-летию со дня рождения А. Н. Бернштама. Ред. Алёкшин, В. А. - Кирчо, Л. Б. - Соколова, Л. А. - Стеганцева, В. Я. Санкт-Петербург 2010, 192-196.

NiKONOROV 2010c = Никоноров, В. П.: Вооружение готов по данным греческих и латинских историчников III-IV вв. In: Краеугольный камень. Археология, история, искусство, культура России и сопредельных стран II. К 80-летию со дня рождения Анатолия Николаевича Кирпичникова. Ред. Джаксон, Т. Н. Казанский, М. М. - Мусин, А. Е. - Сакса, А. И. - Хощинская, Н. В. Москва 2010. 38-48.

Nikonorov-Hudjakov 2004 = Никоноров, В. П. - Худяков, Ю. С.: „Свистящие стрель” Маодуня и „марсов меч” Аттиль. Военное дело азиатских хунну и европейских гуннов. [Militaria Antiqua 6.] Москва 2004.

NIXON 1987 = Nixon, C. E. V. (trans.): Pacatus Panegyric to the Emperor Theodosius. [Translated Texts for Historians. Latin Series 2.] Liverpool 1987.

NonN 1989 = Nonn, U.: Fredegar (Fredegar Chronik). In: LexMa 4. 884.

OBCSINIKOVA 1982 = Обчиникова, Б. Б.: Погребение древнетюркского воина в Центральной Туве. Советская Археология 3 (1982), 210-219.

ODB $=$ The Oxford Dictionary of Byzantium 1-3. Ed. Kazhdan, A. Ex. Ed. Talbot, A. New York - Oxford 1991.

Olajos 1965 = Olajos T.: Merobaudes müvei. Antik Tanulmányok 13 (1966), 172-188.

Olajos 1970 = Olajos T.: Merobaudes. In: Paulys Realencyclopädie der classischen Altertumswissenschaft. Neue Bearbeitung begonnen von Wissona, G. Supplement band Stuttgart 1970, 863-866.

OLAJOS 1977 = Olajos T.: Megjegyzések Maurikios császár avar háborújának utolsó éveihez Theophylaktos Simokattés elbeszélésében. Acta Universitatis Szegediensis de Attila József Nominatae. Acta Historica 58 (1977), 3-12.

OLAJOS 1987 = Olajos T.: Adalékok a görög földre telepedett szlávság történetéhez. Acta Antiqua et Archaeologica 6 (1987), 79-84. 
Olajos 1988 = Olajos, T.: Les sources de Théophylacte Simocatta historien. Budapest 1988.

OlAjos 2001 = Olajos T.: A IX. századi avar történelem görög forrásai. [Szegedi Középkortörténeti Könyvtár 16.] Szeged 2001.

Olajos 2012 = Olajos T. (ford.): Theophülaktosz Szimokattész. Világtörténelem. [Magyar Östörténeti Könyvtár 26.] Budapest 2012.

OlBRICHT-PINKS $1980=$ Olbricht, P. - Pinks, E. (hrsg.): Meng-Ta pei-lu und Hei-Ta shihlüeh: chinesische Gesandtenberichte über die frühen Mongolen 1221 und 1237. [Asiatische Forschungen 56.] Wiesbaden 1980.

OSTROGORSKY 2003 = Ostrogorsky, G.: A bizánci állam története. Ford. Magyar I. L. Németh F. - Prohászka P. Budapest 2003. ${ }^{3}$

PALÁDI-KovÁCs 1997 = Paládi-Kovács A.: A magyar lótartás jellege a honfoglalás korában. In: Honfoglalás és néprajz. Szerk. Györffy Gy. [A Honfoglalásról Sok Szemmel 4.] Budapest 1997, 95-108.

PÁSZTOR 1995 = Pásztor A.: Újabb adatok az avarkori páncélviselet kérdésköréhez. [In: A népvándorláskor fiatal kutatóinak IV. összejövetele. Visegrád 1993. szeptember 20-22.] Altum Castrum 4. A Visegrádi Mátyás király Múzeum füzetei 4 (1995), 5878.

PoHL 1988 = Pohl, W.: Die Awaren. Ein Steppenvolk in Mitteleuropa 567-822 n. Chr. München 1988.

PoHL 2000 = Pohl, W.: Der Awaren und ihre Beziehungen zu den Slawen. In: Slovenija in sosednje dežele med antiko in Karolinško dobo. Začetki Slovenske etnogeneze. Slowenien und die Nachbarländer zwischen Antike und karolingischer Epoche. Anfänge der slowenischen Ethnogenese. Ed. Bratož, R. Ljubjana 2000, 341-353.

PolgÁR 1998 = Polgár Sz.: A kelet-európai nomádok és szomszédaik védelmi rendszerei a koraközépkorban. Acta Universitatis Szegediensis de Attila József Nominatae. Acta Historica 106 (1998), 45-54.

PolgÁR $2004=$ Polgár Sz.: Kora középkori (9-10. század) kelet-európai fegyverkereskedelemre utaló feljegyzések az írott forrásokban. In: Fegyveres nomádok, nomád fegyverek. III. Szegedi Steppetörténeti Konferencia. Szeged, 2002. szeptember 9-10. Szerk. Balogh L. - Keller L. [Magyar Östörténeti Könyvtár 21.] Szeged 2004, 92-100.

POLGÁR 2006 = Polgár Sz.: Kelet-Európa és a nemzetközi kereskedelem a 8-10. században. Doktori értekezés. Kézirat. Szeged 2006. 
Poulin $1980=$ Poulin, J. C.: Anianus. In: LexMa 1. 644.

RANCE 2004 = Rance, P.: The Fulcum, the Late Roman and Byzantine Testudo: the Germanization of Roman Infantry Tactics? Greek, Roman, and Byzantine Studies 44 (2004), 265-326.

RAUTMAN 2006 = Rautman, M. L.: Daily Life in the Byzantine Empire. Westport-London 2006.

RICHTER 1974 = Richter, W.: Die Darstellung der Hunnen bei Ammianus Marcellinus (31.2,1-11). Historia. Zeitschrift für Alte Geschichte 23.3 (1974), 343-377.

RóNA-TAS 1961 = Róna-Tas A.: Nomádok nyomában etnográfus szemmel. [Világjárók 21.] Budapest 1961.

RÓNA-TAS 1985a = Róna-Tas A.: A szarvasi tütartó rovásírásos feliratáról. Magyar Tudomány 30 (1985), 95-98.

RóNA-TAS 1985b = Róna-Tas A.: A szarvasi tütartó felirata. Nyelvtudományi Közlemények 87 (1985), 225-248.

RóNA-TAS 2001 = Róna-Tas A.: Hol volt Kuvrat Bulgáriája? In: Nomád népvándorlások, magyar honfoglalás. Szerk. Felföldi Sz. - Sinkovics B. [Magyar Östörténeti Könyvtár 15.] Budapest 2001, 67-87.

RÓNA-TAS 2002 = Róna-Tas A.: A nagyszentmiklósi kincs feliratairól. In: Az avarok aranya. A nagyszentmiklósi kincs. Magyar Nemzeti Múzeum, Budapest 2002. március 24.-június 30. Főszerk. Kovács T. Szerk. Garam É. Budapest 2002, 120 129.

ROSNER 1999 = ROSNER GY.: Das awarenzeitliche Gräberfeld in Szekszárd-Bogyiszló. [Monumenta Avarorum Archaeologica 3.] Budapest 1999.

SAGASTER 1976 = SAGASTER, K.: Die Weiße Geschichte (Čayan teüke). Eine mongolische Quelle zur Lehre von den Beiden Ordnungen: Religion und Staat in Tibet und Mongolei. [Asiatische Forschungen 41.] Wiesbaden 1976.

SALAMON 1881 = Salamon F.: Hol volt Attila főhadiszállása? Századok 15 (1881), 1-39.

SALAMON-Cs. Sós 1995 = Salamon Á. - Cs. Sós Á.: Cemeteries of the Early Middle Ages (6th-9th Centuries A.D.) at Pókaszepetk. Budapest 1995.

SALAMON-ERDÉLY 1971 = Salamon, Á. - Erdélyi I.: Das völkerwanderungszeitliche Gräberfeld von Környe. [Studia Archaeologica 5.] Budapest 1971.

SÁNDOR 1997 = Sándor K. (szerk.): Rovásírás a Kárpát-medencében. [Magyar őstörténeti könyvtár 4.] Szeged 1992. 
SCHÄFER 1998 = Schäfer T.: Untersuchungen zur Gesellschaft des Hunnenreiches auf kulturantropologischer grundlage. [Studien zur Geschichtsforschung des Altertums 3.] Hamburg 1998.

SCHÄFER 2001a = Schäfer T.: A hun királyi intézmény és hatalom. In: A Kárpát-medence és a steppe. Szerk. Márton A. [Magyar Östörténeti Könyvtár 14.] Budapest 2001, $19-27$.

SCHÄFER 2001b = Schäfer T.: A hun birodalom bukása. In: Nomád népvándorlások, magyar honfoglalás. Szerk. Felföldi Sz. - Sinkovics B. [Magyar Östörténeti Könyvtár 15.] Budapest 2001, 25-35.

SCHÄFER 2004 = Schäfer T.: Lovasnomád hatás a keleti germán népekre. In: Fegyveres nomádok, nomád fegyverek. III. Szegedi Steppetörténeti Konferencia Szeged, 2002. szeptember 9-10. Szerk. Balogh L. - Keller L. [Magyar Östörténeti Könyvtár 21.] Budapest 2004, 26-25.

SCHREIBER 1976 = Schreiber, H.: Die Hunnen. Attila probt den Weltuntergang. Wien 1976.

SCHWARCZ 1991 = Schwarcz, A.: Jordanes. In: LexMa 5. 626-627.

SEVIN 1955 = Sevin, H.: Die Gebiden. München 1955.

SIMON 1991 = Simon L.: Korai avar kardok. Studia Comitatensia 22 (1991), 263-347.

SimON 1995 = Simon L.: Le armi. in: Gli Avari. Un popolo d'Europa. Ed. Menis, G. C. Udine, 115-123.

SINOR $1961=$ Sinor, D.: On Water-Transport in Central Eurasia. Ural-Altaische Jahrbücher 33 (1961), 156-179.

SINOR 1981 = Sinor, D.: The Inner Asian Wariors. Journal of the American Oriental Society 101 (1981), 133-144.

SINOR 1994 = Sinor, D.: The Hun period. In: The Cambridge History of Early Inner Asia. Ed. Sinor, D. Cambridge 1994, ${ }^{2}$ 177-205.

STRAUB 1997 = Straub P.: Avar kori tegezdíszítő csontlemezek motívumtipológiája és kronológiája. A Móra Ferenc Múzeum Évkönyve - Studia Archaeologica 3 (1997), $117-151$.

STRAUB 1999 = STRAUB P.: A Keszthely kultúra kronológiai és etnikai hátterének újabb alternatívája. Zalai Múzeum 9 (1999), 195-224.

STRAUB 2006 = Straub P.: Kiegészítés a kora avar kori tegezcsontok időrendjéhez. Communicationes Archaeologicae Hungariae (2006), 163-177. 
B. SzABÓ 2010 = B. Szabó J.: A honfoglaló magyaroktól a huszárokig. A középkori magyar könnyülovasságról. [A Hadtörténeti Intézet és Múzeum Könyvtára] Budapest 2010. SzABADFALVI 1981 = Szabadfalvi J.: Rudaspányva. In: Magyar néprajzi lexikon IV. Főszerk. Ortutay Gy. Szakszerk. Bodrogi T. - Diószegi V. - Fél E. - Gunda B. Kósa L. - Martin Gy. - Ortutay Gy. - Pócs É. - Rajeczky B. - Tálasi I. - Vincze I. Budapest 1981, 386.

SzÁDECZKY-KARDOSS 1968 = Szádeczky-Kardoss S.: Kuvrat fiának, Kubernek a története és az avar-kori régészeti leletanyag. Antik Tanulmányok 15 (1968), 84-87.

SZÁDECZKY-KARDOSS 1979-1980 = Szádeczky-Kardoss S.: A bolgár történelem forrásai Asparuch elött I-II. Kézirat. Szeged 1979-1980.

SzÁDECZKY-KARDOSS 1983 = Szádeczky-Kardoss S.: Az avar-türk hatás Bizánc hadművészetére. In: Nomád társadalmak és államalakulatok. Szerk. Tőkei F. [Körösi Csoma Kiskönyvtár 18.] Budapest 1983, 317-326.

SzÁDECZKY-KARDOSS $1986=$ Szádeczky-Kardoss, S.: Avarica. Über die Awarengeschichte und ihre Quellen. [Opuscula Byzantina 8.] Szeged 1986.

SzÁDECZKY-KARDOSS 1990 = Szádeczky-Kardoss, S.: The Avars. In: The Cambridge History of Early Inner Asia. Ed. Sinor, D. Cambridge-New York-Oakleigh 1994, 206-228.

SzÁDECZKY-KARDOSS 1996 = Szádeczky-Kardoss S.: Az avarok története Európában. In: Árpád elött és után. Tanulmányok a magyarság és hazája korai történetéröl. Szerk. Kristó Gy. - Makk F. Szeged 1996, 21-30.

SZÁDECZKY-KARDOSS 1998 = Szádeczky-Kardoss S.: Az avar történelem forrásai 557-töl 806-ig. [Magyar Östörténeti Könyvtár 12.] Budapest 1998.

SZEMJONOV 2013 = Семёнов, И. Г.: К истории унногундурского государства. Византийский временник 72 (97) (2013), 45-67.

SzENTPÉTERI 1993a = Szentpéteri, J.: Archäologische Studien zur Schicht der Waffenträger des Awarentums im Karpatenbecken. I. Die waffenkundliche Hinterlassenschaft des awarischen Reiches. Acta Archaeologica Academiae Scientiarum Hungaricae 45 (1993), 165-246.

SZENTPÉTERI 1993b = Szentpéteri, J.: Egy késő avar kori lovas tiszti jelvény - a „csótár”. In: Az Alföld a 9. században. Szerk. Lőrinczy G. Szeged 1993, 49-77.

SzIMONYENKO-LoBAJ 1991 = Симоненко, А. В. - Лобай, Б. И.: Сарматы СевероЗападного Причерноморья в І в. н.э. Киев 1991. 
SZKRZSINSZKAJA 1960 = Скржинская, Е. Ч. (пер.): Иордан о происхождении и деяниях гетов. Москва 1960.

SzŐKE 1998 = Szöke B. M.: A korai középkor hagyatéka a Dunántúlon. Ars Hungarica 26 (1998), 257-319.

SzŐKE 2000 = Szőke B. M.: Das Archäologische Bild der Slawen in Südwestungarn. In: Slovenija in sosednje dežele med antiko in Karolinško dobo. Začetki Slovenske etnogeneze. Slowenien und die Nachbarländer zwischen Antike und karolingischer Epoche. Anfänge der slowenischen Ethnogenese. Ed. Bratož, R. Ljubjana 2000, $477-500$.

SzÖKE 2006 = Szőke B. M.: Nagy Károly hadjárata az avarok elln 791-ben. Arrabona 44 (2006), 497-522.

SzŐLLŐSY 1992 = Szőllősy, G.: Újabb adatok a népvándorláskori íjtípusok kérdésköréhez. A Nyíregyházi Jósa András Múzeum Évkönyve 30-31:1987-89 (1992), 349-367.

SzŐLLŐSY $2001=$ Szőllőssy G.: Mi célt szolgált a szablya fokéle? Kísérleti megközelítések. [Hadak útján XII. „Régiók és kistájak a népvándorlás korában.” A népvándorlás kor fiatal kutatói konferenciájának előadásai (Simontornya, 2001. szeptember 3-5.) Szerk. Gaál A.] A Wosinszky Mór Múzeum Évkönyve 23 (2001), $275-291$.

SzŐLLŐSY 2004 = Szőllősy G.: Az avar íjak és a magyar íj fejlődéstörténeti kapcsolatai. In: Fegyveres nomádok, nomád fegyverek. III. Szegedi Steppetörténeti Konferencia Szeged, 2002. szeptember 9-10. Szerk. Balogh L. - Keller L. [Magyar Östörténeti Könyvtár 21.] Budapest 2004, 53-61.

SZÖM = Bevezetés a magyar östörténet kutatásainak forrásaiba I/2. Szerk. Hajdú P. Kristó Gy. - Róna-Tas A. Budapest 1988. ${ }^{2}$

SzÜCSI 2012 = Szücsi F.: A kora- és késő avar kori balták és fokosok. In: Hadak útján. XX. Népvándorláskori Fiatal Kutatóinak XX. Összejövetelének konferenciakötete. Budapest-Szigethalom, 2010. október 28-30. Szerk. Petkes Zs. Budapest 2012, $121-138$.

TABALDIEV-BABAJAROV-UMIROV-JACENKO 2013 = Табалдиев, K. - Бабаяров, Г. Умиров, К. - Яценко, С. А.: Государственный удел: памятники на территории Кыргызстана и Узбекистана. In: Западный Тюркский каганат. Атлас. Ред. Досымбаева, А. - Жолдасбеков, М. Астана 2013, 491-606.

TÄCKHOLM 1969 = Täckholm, U.: Aetius and the Battle on the Catalaunian Fields. Opuscula Romana 7 (1969), 259-276. 
TALBOT 1991 = Talbot, A. M.: Xanthopoulos, Nikephoros Kallistos. In: ODB 3. 2207.

TeAll 1965 = Teall, J. L.: The Barbarians in Justinian's Armies. Speculum 40 (1965), 294-322.

THOMPSON 1947 = Thompson, E. A.: Notes on Priscus Panites. Classical Quarterly 41 (1947), 61-65.

ThOMPSON 1958 = Thompson, E. A.: Early Germanic Warfare. Past and Present 14 (1958), 2-29.

THOMPSON 2003 = Thompson, E. A.: A hunok. Ford. Felföldi Sz. Szeged 2003. ${ }^{2}$

ToDD 1972 = Todd, M.: Everyday Life of the Barbarians. Goths, Franks and Vandals. London-New York 1972.

TOLKIEN 1960 = Tolkien, C. (trans.): Saga Heiđreks konungs ins vita. The Saga of King Heidrek the Wise. London 1960.

TOMKA 1986 = Tomka, P.: A sztyeppei temetkezési szokások sajátos változata. A hun halotti áldozatok. Arrabona 22-23:1980-1981 (1986), 35-55.

TOMKA 1990 = Tomka, P.: Die Frage der ethnischen oder kulturellen Verwandtschaft bzw. interethnischer Wirkung im Spiegel der Begräbnissitte. A Wosinszky Mór Múzeum Évkönyve 15 (1990), 163-174.

TOMKA 1993a = Tomka, P.: Hun hadmüvészet. In: Hunok - gepidák - langobardok. Történeti tézisek és címszavak. Összeállította: Bóna I. [Magyar Östörténeti Könyvtár 6.] Szeged 1993, 16-17.

TOMKA 1993b = Tomka, P.: Hun fegyverzet. In: Hunok - gepidák - langobardok. Történeti tézisek és címszavak. Összeállította: Bóna I. [Magyar Östörténeti Könyvtár 6.] Szeged 1993, 17-18.

TOMKA 1997 = Tomka P.: Étkezési és vendégfogadási szokások a népvándorláskori nomád népeknél. [In: „Nyereg alatt puhítjuk ...?” avagy Vendéglátási szokások a honfoglaló magyaroknál és a rokon kultúrájú népeknél címü 1996. október 10-11-i rendezvénysorozat Tudományos Konferenciájának tanulmányai] Ómagyar Kultúra 10 (1997), 86-93.

TOMKA 2005 = Tomka P.: Korai avar sírok Börcs-Nagydombon (Györ-Moson-Sopron megye). Archaeologiai Értesitó 130 (2005), 137-179.

TÖRÖK 1954 = Török Gy.: Kora-avar sírok Móron. Archaeologiai Értesítő 81 (1954), 5460.

TóTH 1930 = Tóth, Z.: Attila's Schwert. Studie über die Herkunft des sogenannten Säbels Karls des Grossen in Wien. Budapest 1930. 
TŐSÉR 2006 = TŐSÉR M.: Bizánci terjeszkedés a X. században - ostromtechnikák elméletben és gyakorlatban. Hadtörténeti Közlemények 119 (2006), 459-479.

TRUgly 2008 = Trugly S.: A Komárom-Hajógyári avar temető és telep. [Opitz Archaeologica 2.] Budapest 2006.

VÁCZY 1974 = Váczi P.: A frank háború és az avar nép. Századok 108 (1974), 1041-1061.

VÁCZI 1986 = Váczi P.: A hunok Európában. In: Attila és hunjai. Szerk. Németh Gy. Budapest 1940 (reprint 1986).

VÁSÁRY 1972 = Vásáry I.: Runiform signs on objects of the Avar period (6-8 th. cc. A.D.). Acta Orientalia Academiae Scientiarum Hungaricae 25 (1972), 335-347.

VÁSÁRY 1986 = Vásáry I.: Az Arany Horda. Budapest 1986.

VÁSÁRY 1993 = Vásáry I.: A régi Belsö-Ázsia története. [Magyar Östörténeti Könyvtár 19.] Budapest 2003. ${ }^{2}$

VÉR 2012 = Vér M.: Információtörténeti markerek a Mongol Birodalom történetében. Aetas 27 (2012), 144-154.

VÉKONY 1987 = Vékony G.: Későnépvándorláskori rovásfeliratok a Kárpát-medencében. Szombathely-Budapest 1987

VESZPRÉMY 1991 = Veszprémy L.: A színlelt visszavonulás középkori megítéléséröl. In: Unger Mátyás emlékkönyv. Emlékkönyv Unger Mátyás negyedszázados egyetemi történésztanári müködése emlékére, születésének hetvenedik évfordulója alkalmából. Szerk. E. Kovács P. - Kalmár J. - V. Molnár L. Budapest 1991, 1-5.

VESZPRÉMY 2000 = Veszprémy L.: Hadügy a koraközépkori Nyugat-Európában. Társadalom és Honvédelem 4 (2000), 106-117.

VESZPRÉMY 2006 = Veszprémy L.: A középkori történetírás és forrásai. Hadtörténelmi Közlemények 119 (2006), 517-523.

VESZPRÉMY 2008 = Veszprémy L.: Lovagvilág Magyarországon. Lovagok, keresztesek, hadmérnökök a középkori Magyarországon. Válogatott tanulmányok. [A Hadtörténeti Intézet és Múzeum Könyvtára] Budapest 2008.

VIDA $2008=$ Vida, T.: Conflict and coexistence : the local population of the Carpatian basin under Avar rule (sixth to seventh century). In: The Other Europe in the Middle Ages. Avars, Bulgars, Khazars and Cumans. Ed. Curta, F. [East Central and Eastern Europe in the Middle Ages 450-1450. 2.] Leiden-Boston 2008, 13-46.

VITLJANOV 1996 = Витлянов, С.: Старо-българского въоръжение по археологически данни от Плиска, Мадара и Велики Преслав. София 1996. 
VogT-SPIRA 1994 = Vogt-Spira, G.: Einführung. Der Waltharius im Bezugsfeld lateinischer Schriftkultur, mündlicher Heldensage und der Ethik des Christentums. In: Walharius. Lateinisch/Deutsch. Hrsg. Vogt-Spira, G. Stuttgart 1994, 5-20.

VOLLMANN 1991 = Vollmann, B. K.: Frühe Deutsche Literatur und Lateinische Literatur in Deutschland 800-1150. [Bibliothek des Mittelalters 1.] Frankfurt 1991.

VRYONIS 1981 = Vryonis, S.: The Evolution of Slavic Society and the Slavic Invasions in Greece. The First Major Slavic Attack on Thessaloniki, A. D. 597. Hesperia 50 (1981), 378-390.

VRYONIS 1991 = Vryonis, S.: Sabiri. In: $O D B$ 3. 1824.

WATERSON 2007 = Waterson, J.: The knights of Islam. The wars of the mamluks. London 2007.

WERNER 1956 = Werner, J.: Beiträge zur Archaeologie des Attila-Reiches. München 1956.

WERNER 1974 = Werner, J.: Nomadische Gürtel bei Persern, Byzantinern und Langobarden. In: Atti del covegno internazionale sul tema: La civiltà dei longobardi in Europa (Roma, 24-26 maggio 1971; Cividale del Friuli, 27-28 maggio 1971) Comi. Ord. Cerulli, E.-Cagiano de Azevedo, M.-Demarco, D.Gnudi, C.-Morghen, R.-Paradisi, B.-Pontieri, E.-Salmi, M. Roma 1974, 109-139.

WhItBY 1988 = Whitby, M.: The Emperor Maurice and his Historian. Theophylact Simocatta on Persian and Balkan Warfare. Oxford 1988.

WhitBY-WhitBy 1986 = Whitby, M. - Whitby, M. (trans.): The History of Theophylact Simocatta. Oxford 1986.

WIRTH 1999 = Wirth, G.: Attila. Das Hunnenreich und Europa. Stuttgart-Köln-Berlin 1999.

WOLFRAM 1987 = Wolfram, H.: Die Geburt Mitteleuropas. Geschichte Österreichs vor seiner Entstehung 378-907. Wien 1987.

Wolfram 1990 = Wolfram, H.: Die Goten von den Anfängen bis zur Mitte des sechsten Jahrhunderts. Entwurf einer historischen Ethnographie. München 1990.

WOLFRAM 1993 = Wolfram, H.: L'armée romaine comme modèle pour l'Exercitus Barbarorum. In: L'armée romaine et les Barbares du IIIe au VIIe siècle. Ed. Vallet, F. - Kazanski, M. Saint-Germain-en-Laye 1993, 13-15.

ZASZECKAJA 1994 = Засецкая, И. П.: Культура кочевников южнорусских степей в гуннскую эпоху (конец IV-V. вв.). Санкт-Петербург 1994. 
ZIEMANN 2007 = Ziemann, D.: Vom Wandervolk zur Grossmacht. Die Entstehung Bulgariens im fühen Mittelalter (7.-9. Jahrhundert). [Kölner Historische Abhandlungen 43.] Köln-Weimar-Wien 2007.

ZIMONYI 1990 = Zimonyi, I.: The Origins of the Volga Bulghars. [Studia Uralo-Altaica 32.] Szeged 1990.

ZIMONYI 2004 = Zimonyi I.: A honfoglaló magyar haderő létszáma. In: Fegyveres nomádok, nomád fegyverek. III. Szegedi Steppetörténeti Konferencia. Szeged, 2002. szeptember 9-10. Szerk. Balogh L. - Keller L. [Magyar Östörténeti Könyvtár 21.] Szeged 2004, 101-111.

ZIMONYI 2005 = Zimonyi I.: Muszlim források a honfoglalás elötti magyarokról. A Ğayhāni-hagyomány magyar fejezete. [Magyar Östörténeti Könyvtár 22.] Szeged 2005.

\section{3. Linkográfia}

BRUENNE.htm $=$ http://home.arcor.de/glanlaender/bibliothek/bruenne.htm (letöltés ideje $200304.08)$

MCCOTTER $=$ McCotter, S.: Byzantines, Avars and the Introduction of the Trebuchet. http://74.125.39.104/search?q=cache:_wTmVrjtNb0J:www.deremilitari.org/resourc es/articles/mccotter1.htm+stephen+McCotter\&hl=hu\&ct=clnk\&cd=3\&gl=hu\&clien $\mathrm{t}=$ firefox-a (letöltés ideje: 2008. 10.17.07.30)

SPROSTON 2012 = Sproston, E.: Særnordiske Ord-Scandinavian - only Words http://germanic.zxq.net/Scand-only.html (letöltés ideje: 2013. 02. 01. 23.30)

SZLANOV 2000 = Сланов, А.: Военное искусство алан в I-III в.в. н.э. Дарьял 2000-1. http://www.darial-online.ru/2000_5/slanov.shtml (letöltés ideje: 2013. 02. 02. 05.30) 
7. Mellékletek 